$$
\begin{aligned}
& \text { شرح حليث }
\end{aligned}
$$

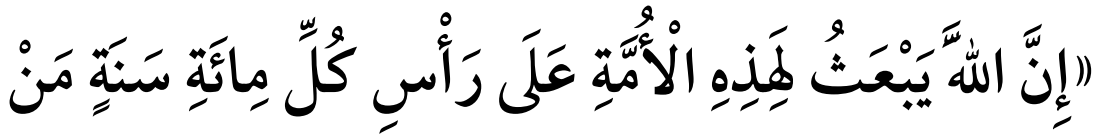

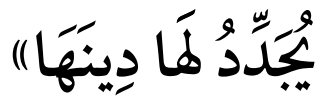$$
\text { إعداد }
$$$$
\text { أحمد الخضر الجوهرى }
$$$$
\text { أستاذ الحليث المساعد }
$$$$
\text { كلية أصول الدين - فرع جامعة الأزهر - المنصورة }
$$ 


\section{بسم الله الرحمن الرحيم}

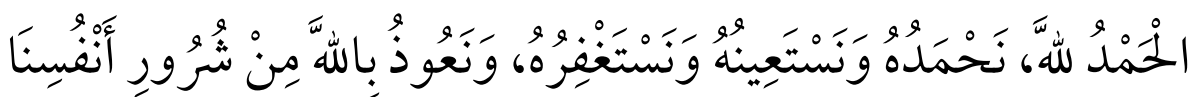

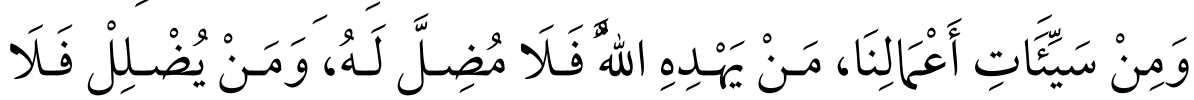

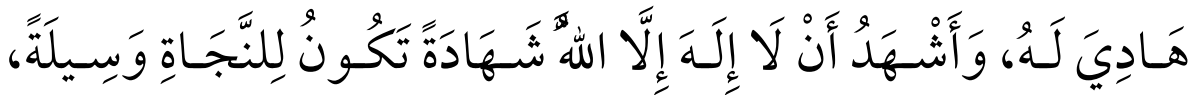

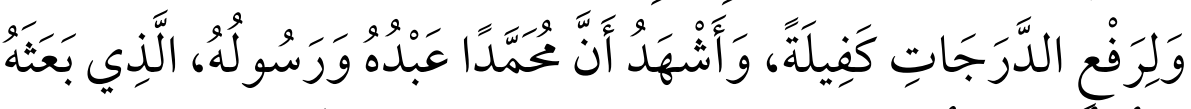

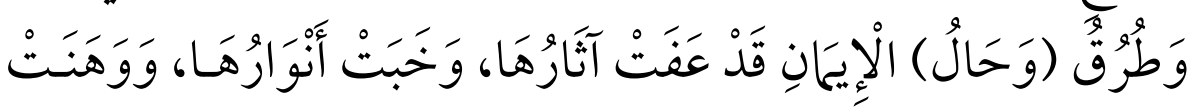

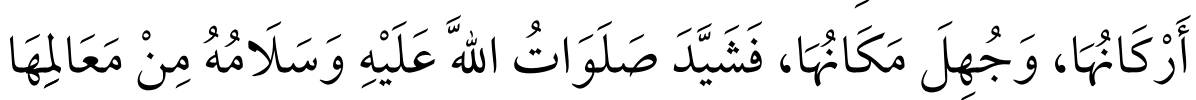

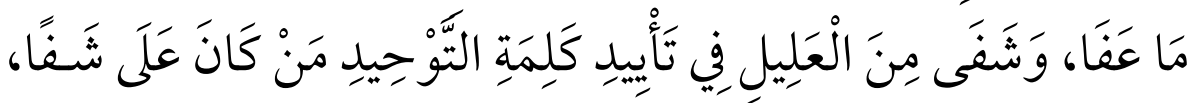

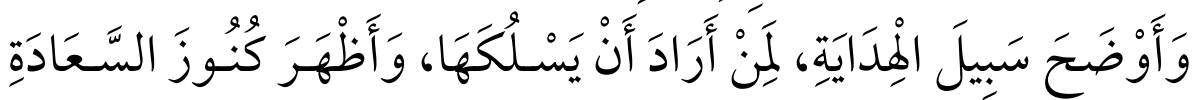

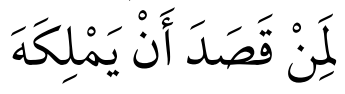




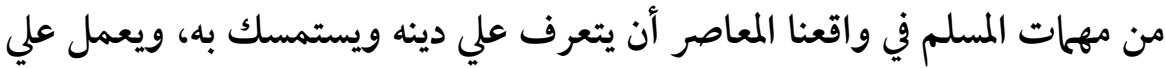

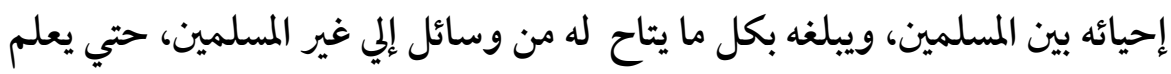

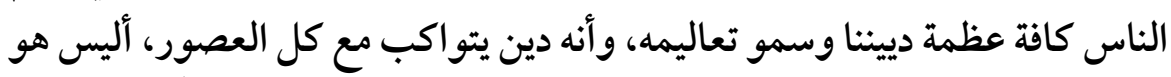

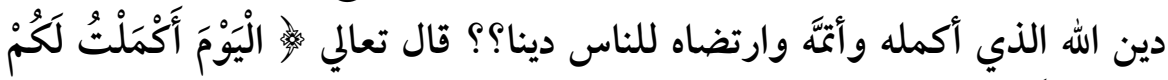

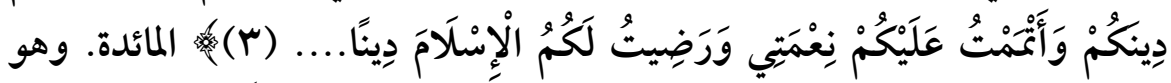

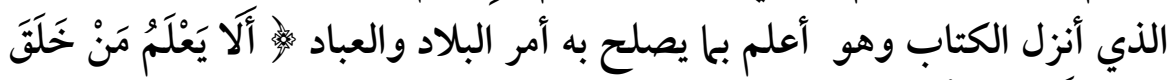

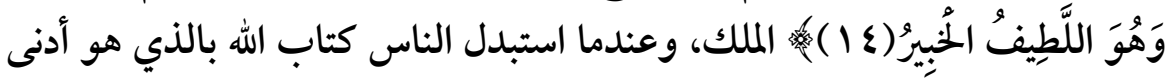

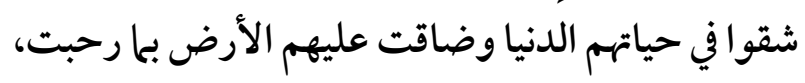

ونحن المسلمين معنيون بهداية البشر ودلالتهم علي الطريق، وهذا يتطلب منَّا العمل

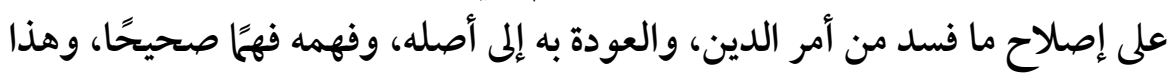

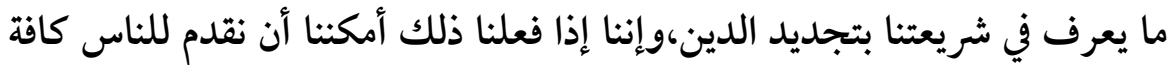

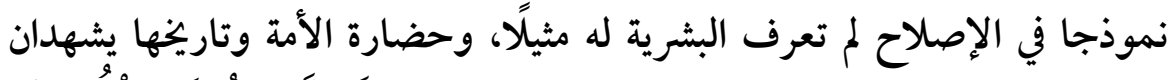

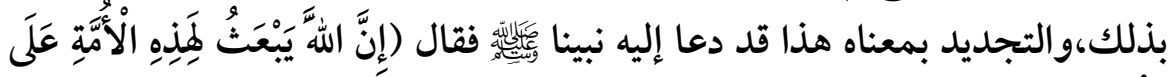

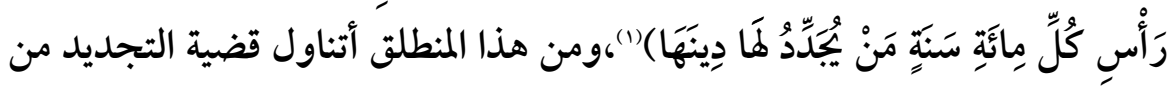
منظور علماء الأمة ومفكريها.

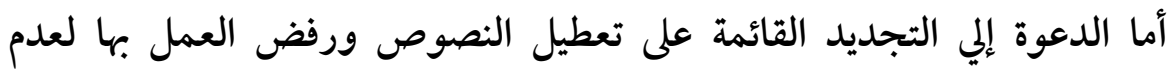

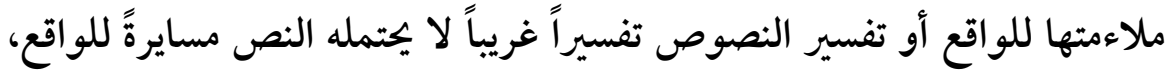

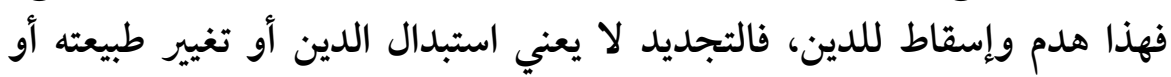

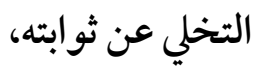

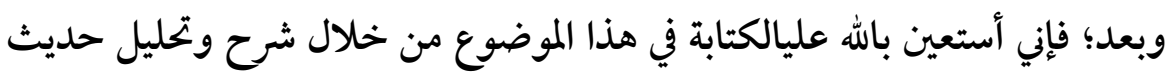

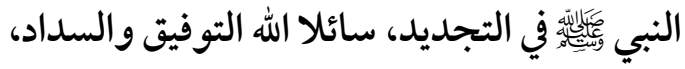

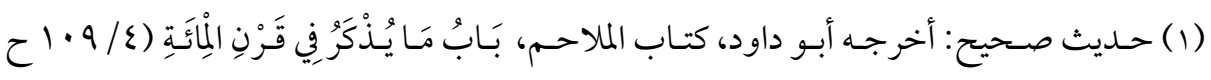

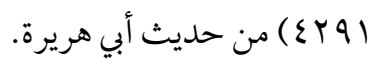




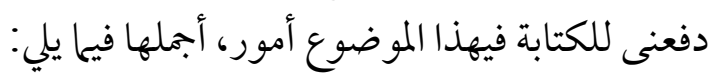

$$
\text { حاجة الأمة في و اقعنا المعاصر إلى تجديد دينها. }
$$

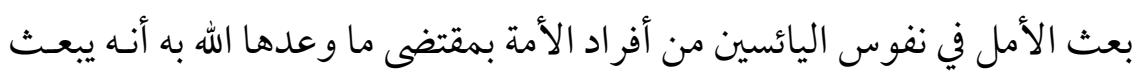

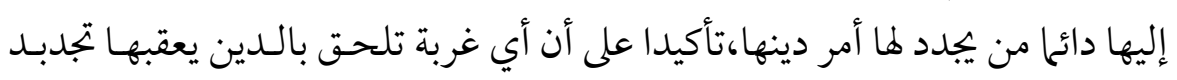

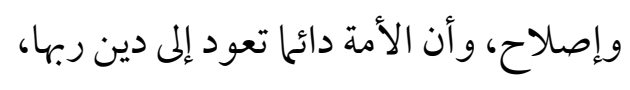

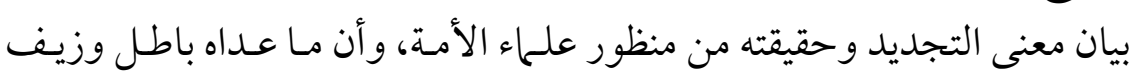

$$
\text { وهوى متبع · تصني }
$$

تصحيح مفهوم التجديد لدى كثير من أفراد الأمة وتخليصه مما قد شابه مـن خلط

$$
\text { وتشويه، }
$$

إظهار بطلان زعم القائلين أن التمسك بالدين عودة إلى الوراءوو إثبات أنها عـودة

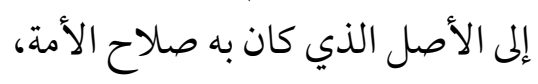

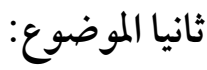

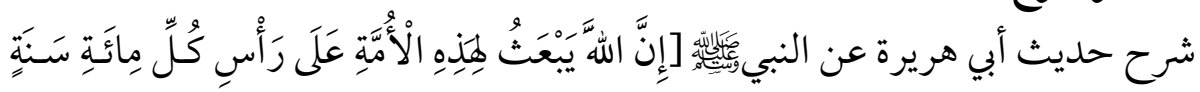

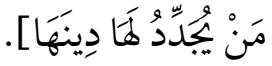

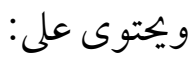

$$
\begin{aligned}
& \text { تخريج الحديث ، در اسة رجال الإسناد، الحكم علي الحديث. }
\end{aligned}
$$

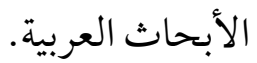

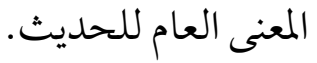

$$
\begin{aligned}
& \text { فقه الحديث: }
\end{aligned}
$$

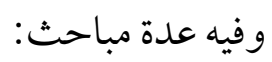

$$
\begin{aligned}
& \text { المبحث الأول: معنى التجديد وحقيقته. } \\
& \text { المبحث الثاني: الدين المُجَدَد. } \\
& \text { المبحث الثالث: حاجة الأمة إلى التجديد. لمديد. }
\end{aligned}
$$

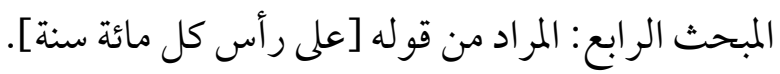


المبحث الخامس: بقاء الدين واستمراره إلى قيام الساعة.

المبحث السادس: أحاديث تتعارض فى معناها مع حديث الباب.

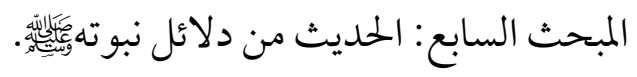

المبحث الثامن: تجديد الإيمان.

المبحث التاسع: شروط المجدد.

المبحث العاشر : مكانة المجدد.

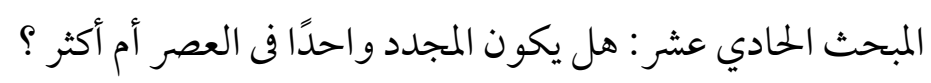

المبحث الثاني عشر : المجددون عبر تاريخ الدولة الإسلامية.

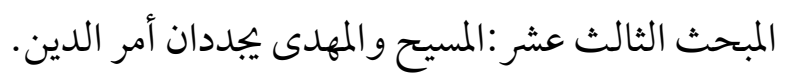

الخاتمة:

$$
\begin{aligned}
& \text { - وفيها نتائج الدراسة وثلمارها. } \\
& \text { " فهرست للمصادر والمراجع. } \\
& \text { فهرست للمو ضوعات. }
\end{aligned}
$$

ثالثا أمور مهمة:

• اعتمدت في كتابة هذا البحث على كتب التراث وخاصة كتب الحـديث الشر-يف كـا

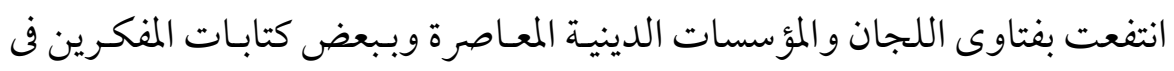
العصر الحديث وقد كانت عنايتى دراسة الموضوع في ضوء ما ذكره علماء المسـلمين

$$
\text { في قضية التجديد. }
$$

• الاعتماد على الحلديث النبوي وأقوال السلف وعلماء الأمـة في تأصسيل مفـردات هـذا

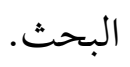

• قمت بتخريج الأحاديث والحكم عليها فى غير الصحيحين أمـا الصحيحان فـالعزو

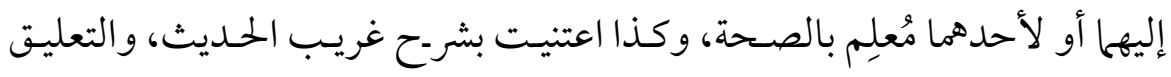

عليها. 


\section{رابعًا قصيدة في المجددين:}

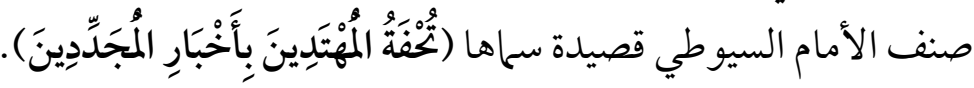

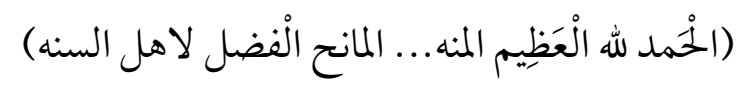

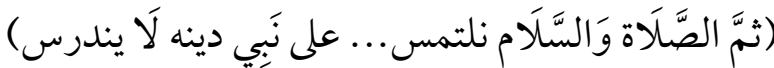

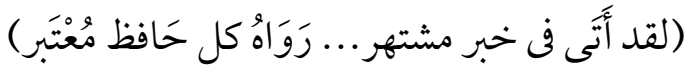

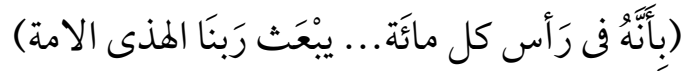

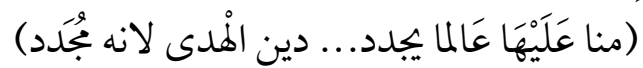

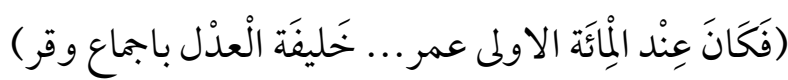

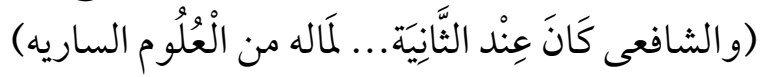

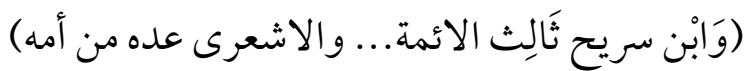

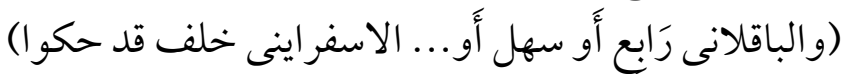

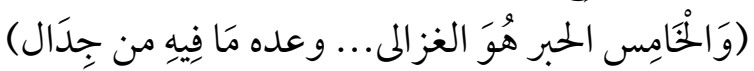

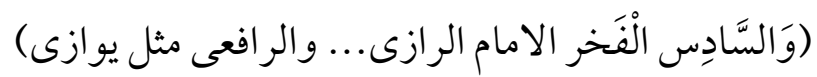

(وَالسَّابع الراقى الى المراقى ... ابْنَ دَقِيق الْعِيد بِاتِّفَاقِ)

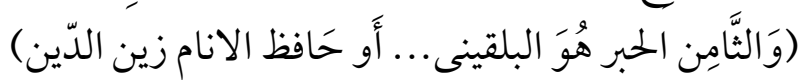

(وعد سبط الميلق الصوفيه.... لَو وجدت ماتو مائته وَفِيه)

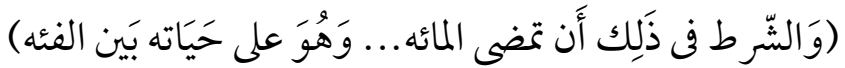

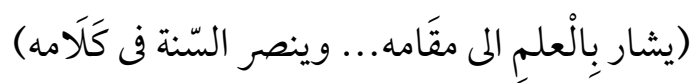

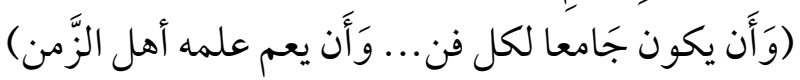

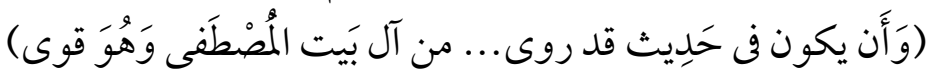

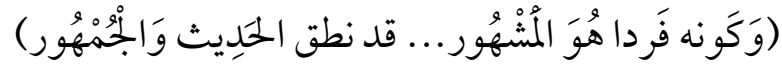

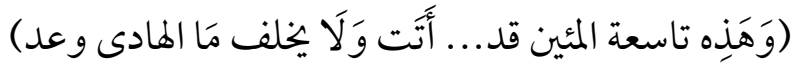

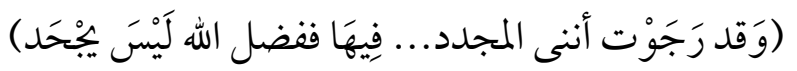

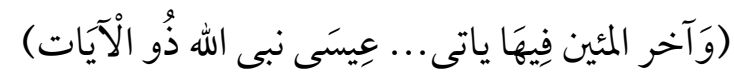

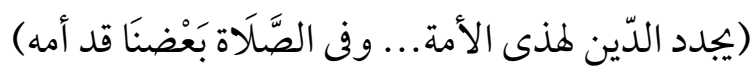




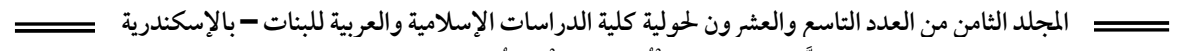

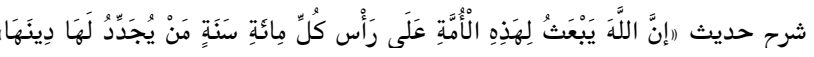

$$
\begin{aligned}
& \text { (مقرر الشرعناوَيهكم.... بحكمنا وفى السَّمَاء يعلم) }
\end{aligned}
$$

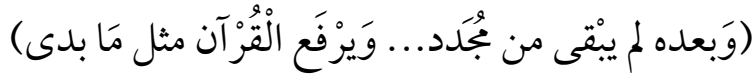

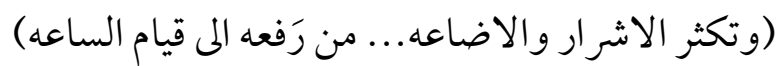

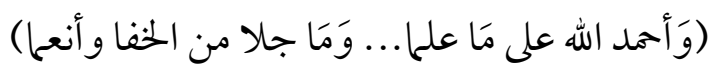

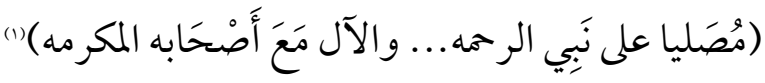

(1) خلاصة الأثر في أعيان القرن الحادي عشر (r/ ع ع r، ع r).

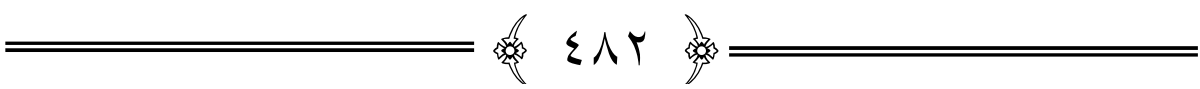




$$
\begin{aligned}
& \text { شرح الحديث } \\
& \text { كتاب الملاحم } \\
& \text { باب ما يذكر في قرن المائة }
\end{aligned}
$$

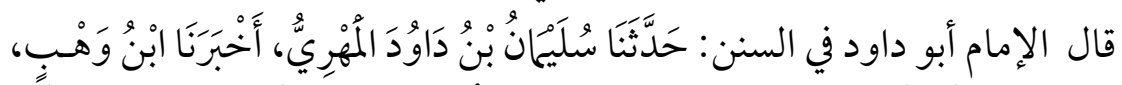

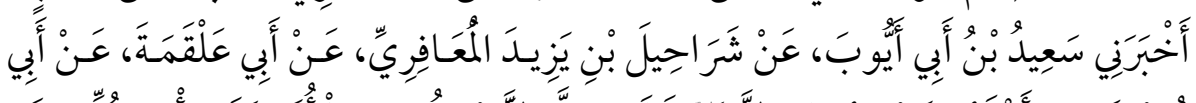

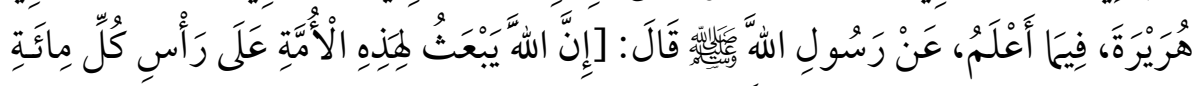

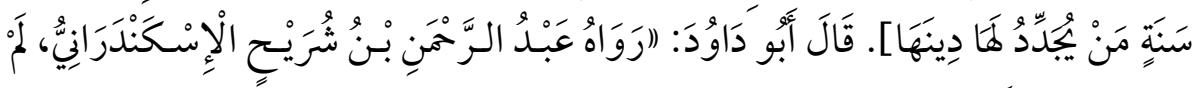

$$
\begin{aligned}
& \text { يَيَزٌْ بِهِ شَرَاحِيَلَ. } \\
& \text { تخريج الحديث: }
\end{aligned}
$$

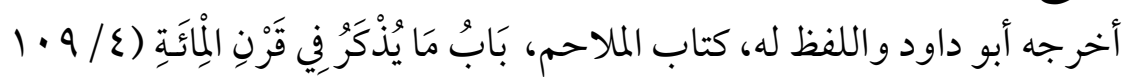

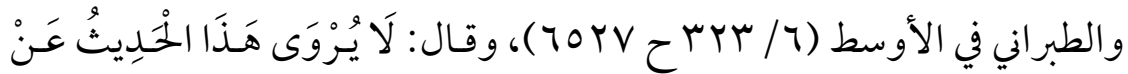

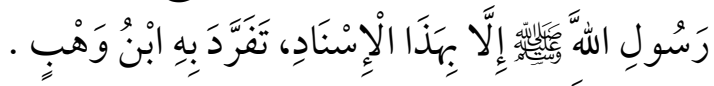

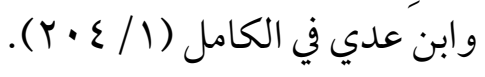

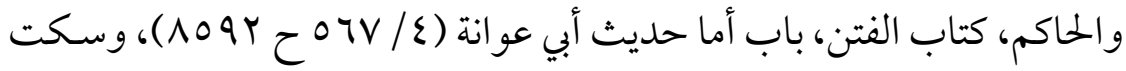

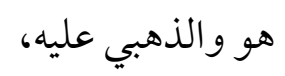

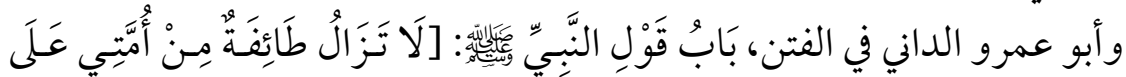

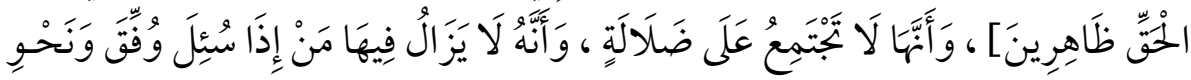

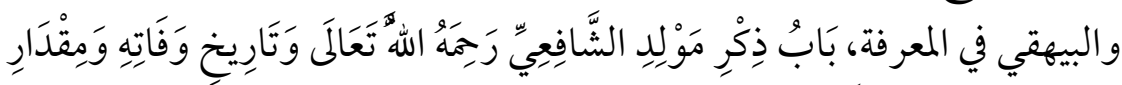

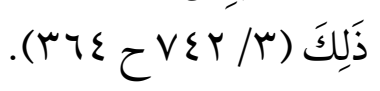

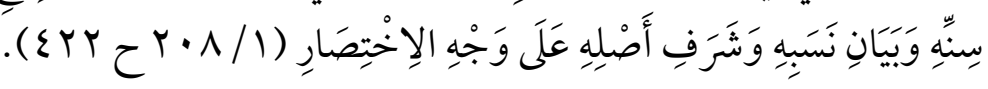

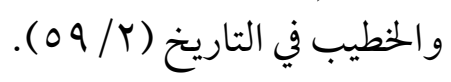

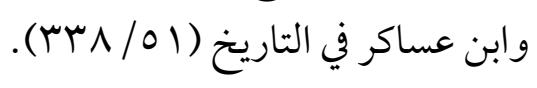

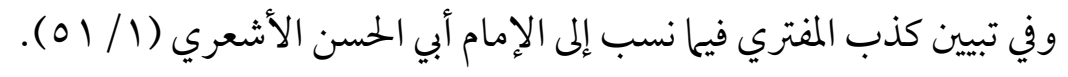

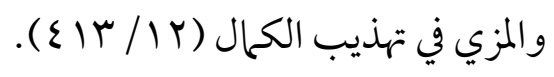

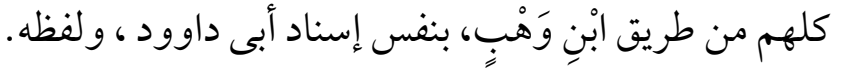


وقول أبي داود عقب الحديث:"رواه عبد الرحمن بن شريح الإسكندر اني لم يجزز بـه

شر احيل "

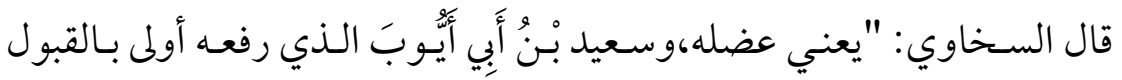

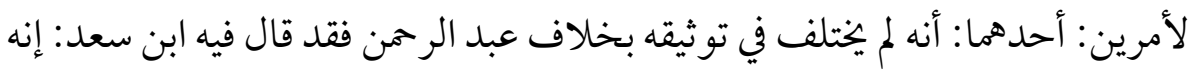

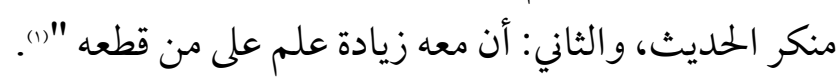

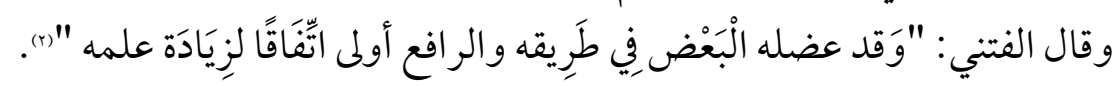

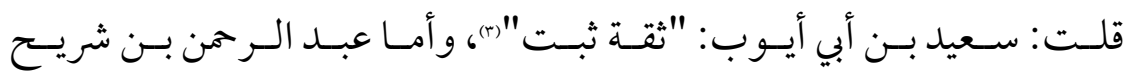

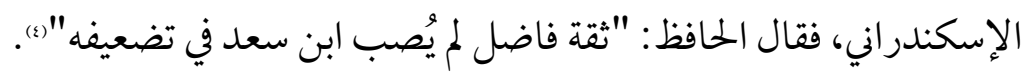

وهذا الحديث قد اتفق على تصحيحه كثير من علماء الأمة:

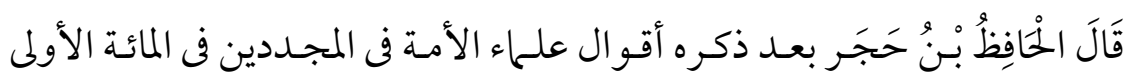

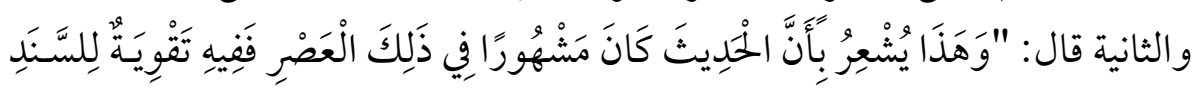

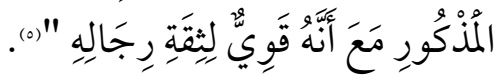

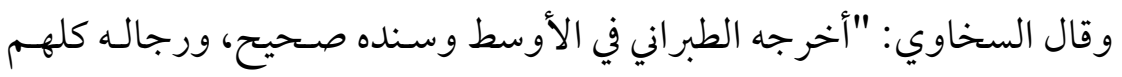

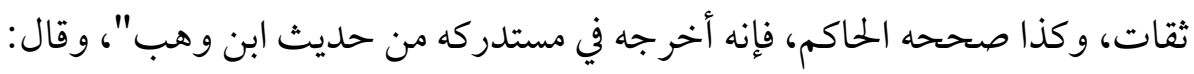

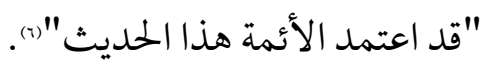

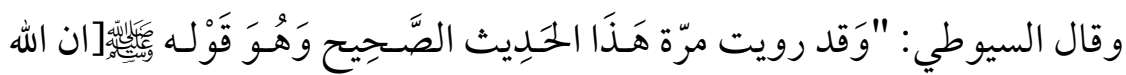

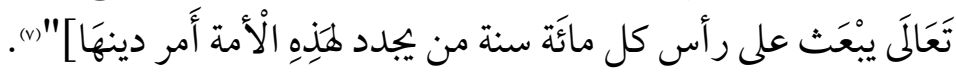

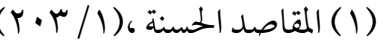

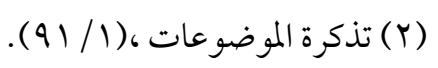

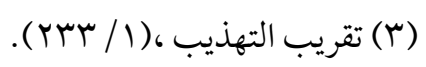

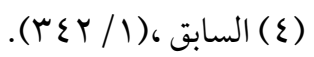

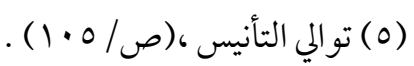

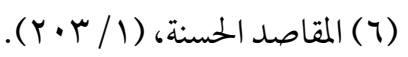

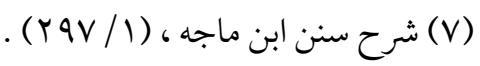

$\varepsilon \wedge \varepsilon$ 


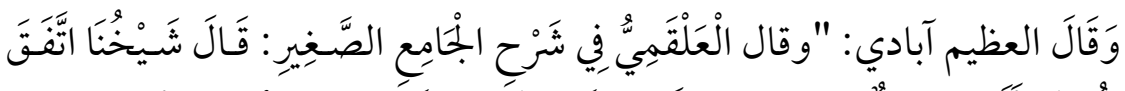

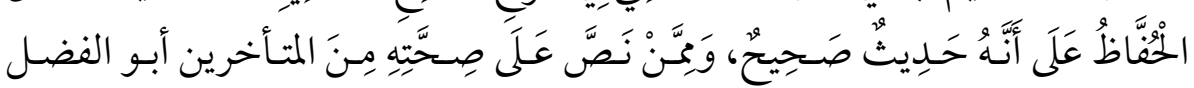

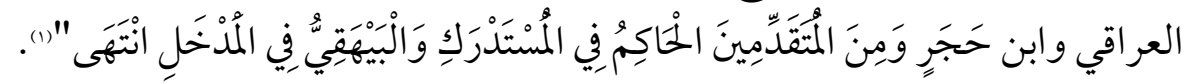

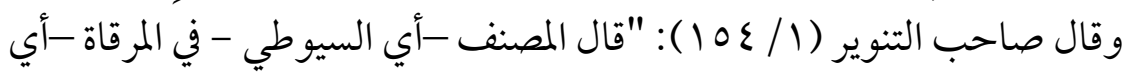

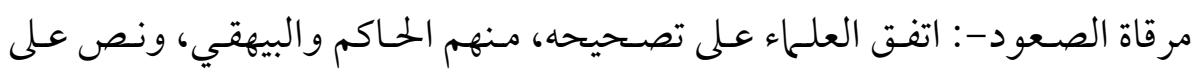

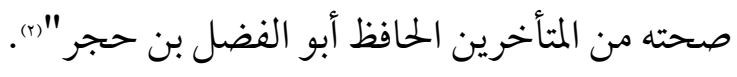

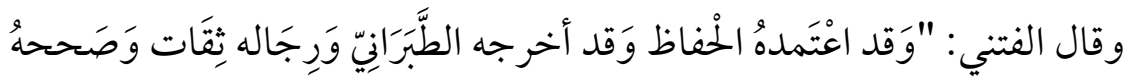

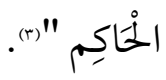

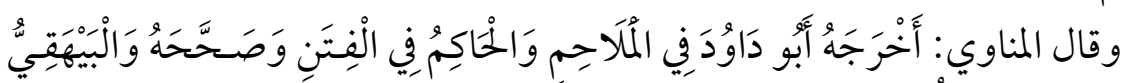

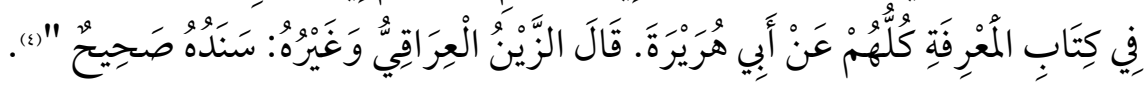

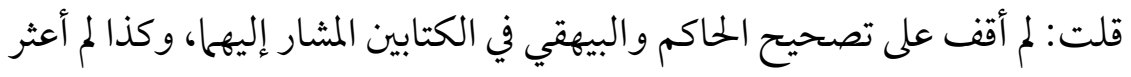

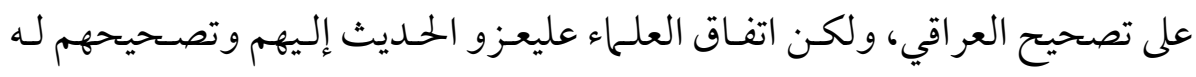

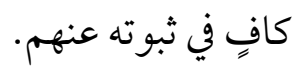

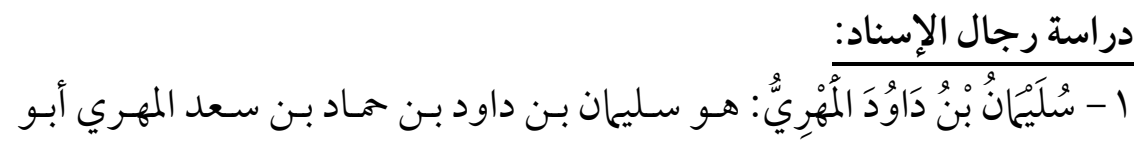

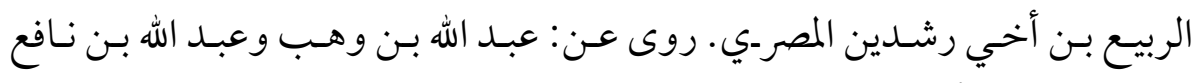

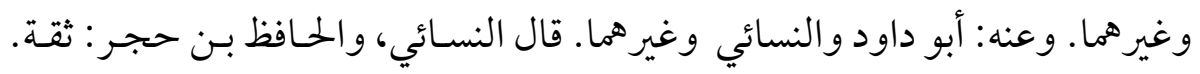

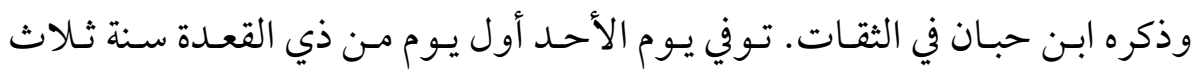
وخمسين ومائتين (o).

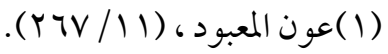

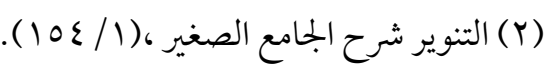

$$
\begin{aligned}
& \text { (Y) (Y) (Yكرة الموضوعات، (Y) (Y) (Y) ). }
\end{aligned}
$$

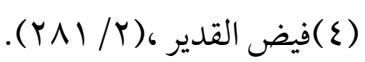

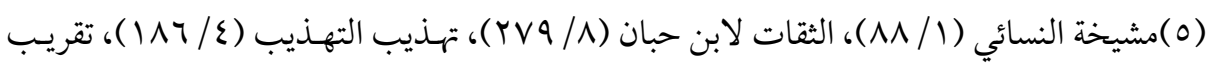

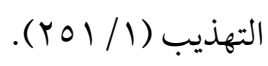


r-ابْنُ وَهْبٍ: هوعبد الله بن وهب بن مسلم القرشي مولاهم أبو محمد المصر-ي.

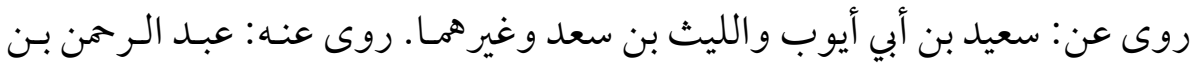

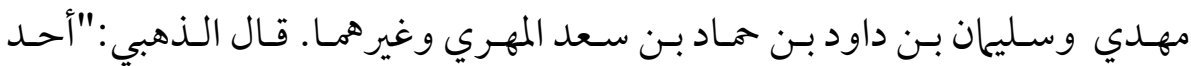

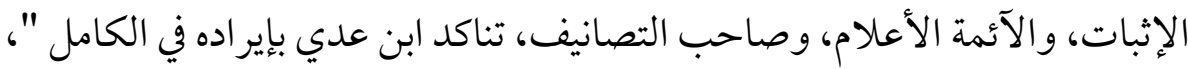
وقال الحافظ: فقيه ثقة حافظ عابد، من التاسعة. مات سنة سبع وتسعين ( ومائة ) وله اثنتان وسبعون سنة (1)

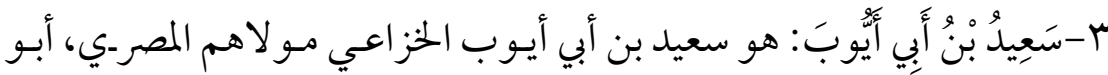

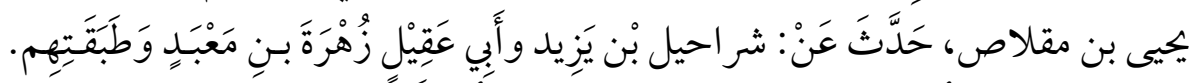

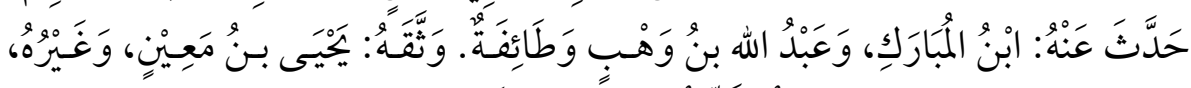

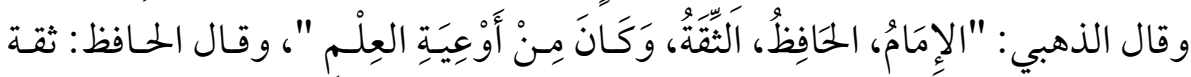

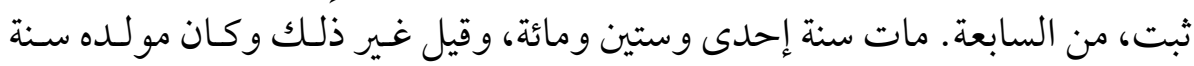
مائة (1)

ع -شَرَاحِيلَ بْنِ يَزِيََ المُعَافِرِيّ: هو شر احيل بن يزيد المعافري المصري. روى عن:

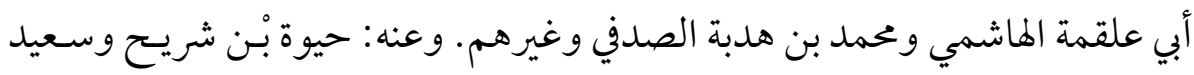

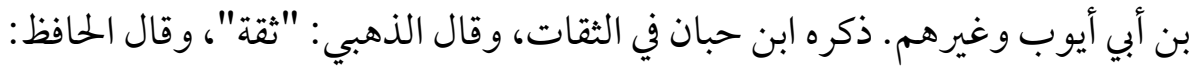
صدوق، من السادسة مات بعد العشرين ومائة (r).

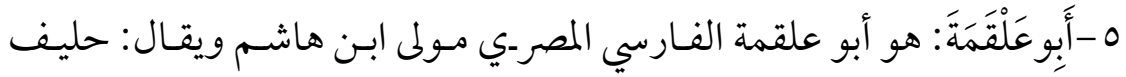

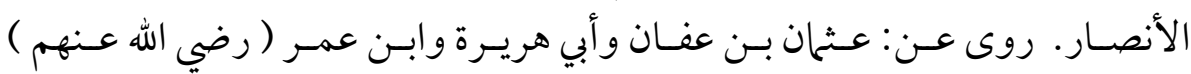

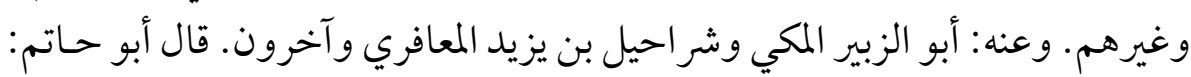

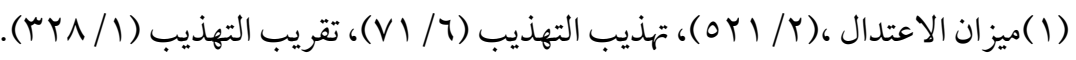

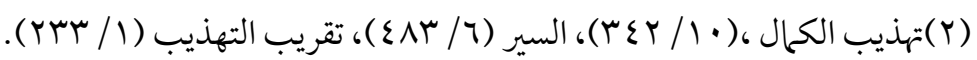

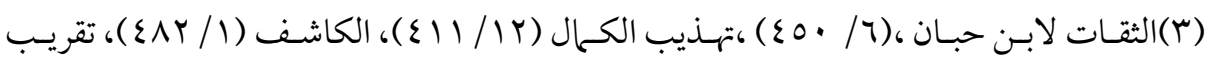
التهذيب (1)/ror).
} 
أحاديثه صحاح، وقال العجلي: مصري تابعي ثقة، وذكره ابن حبان في الثقات، وقال

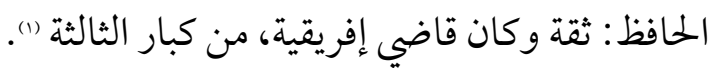

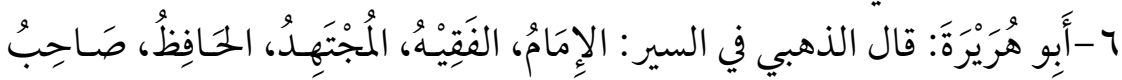

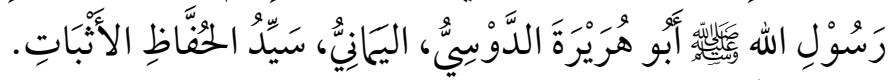

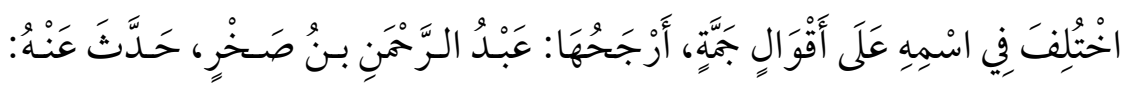

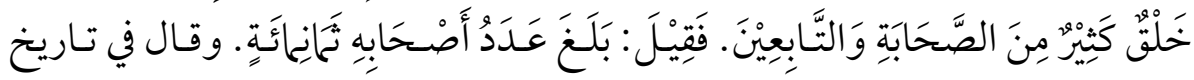

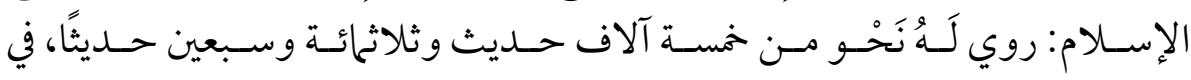

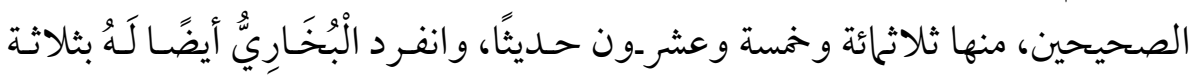

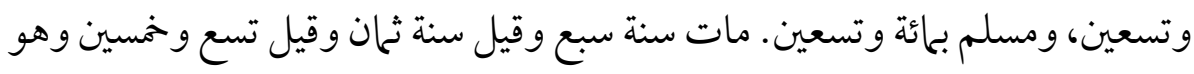
ابن ثمان وسبعين سنة) (1)

$$
\text { إسناده صحيح، وصحى الحديث: }
$$

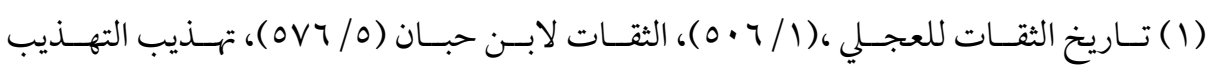

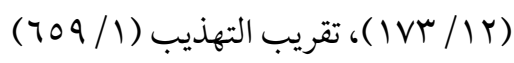

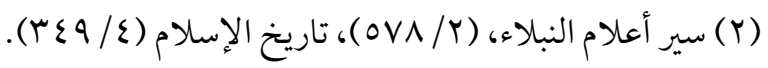

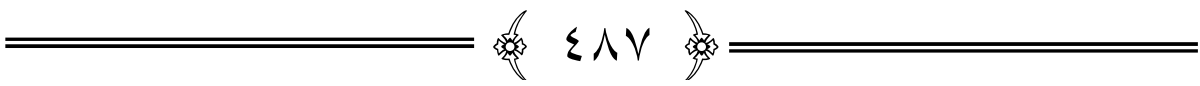




\section{| الأبحاث العربية}

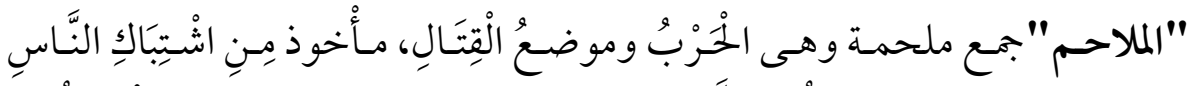

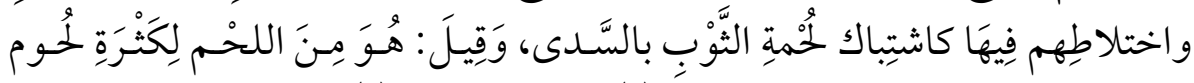

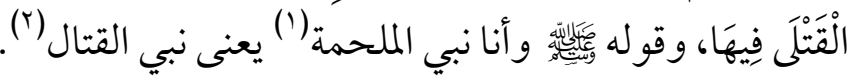

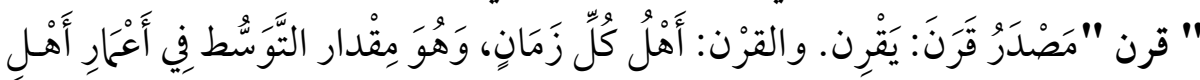

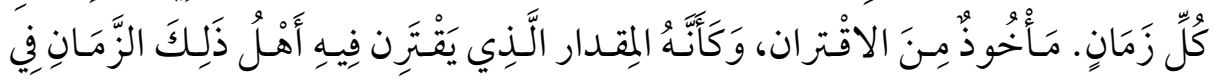

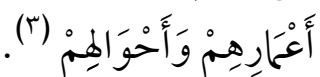

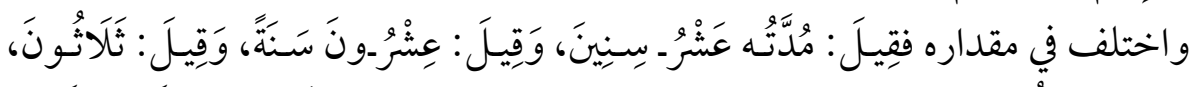

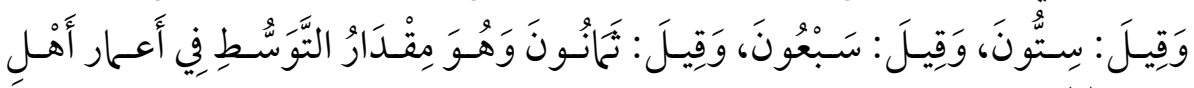

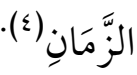

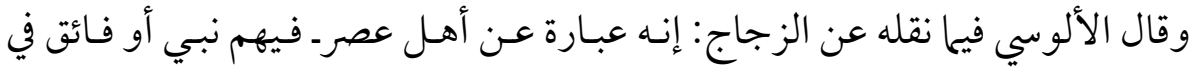

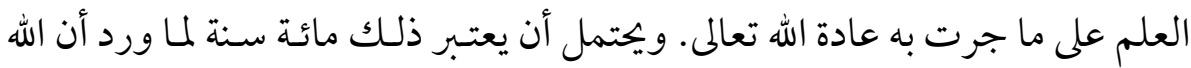

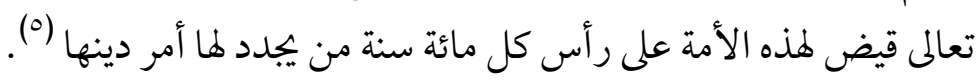

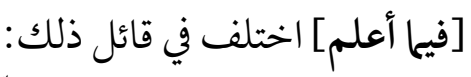

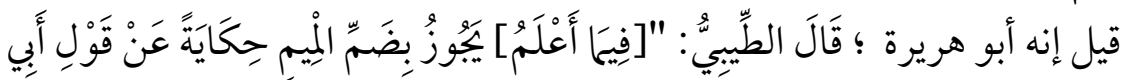

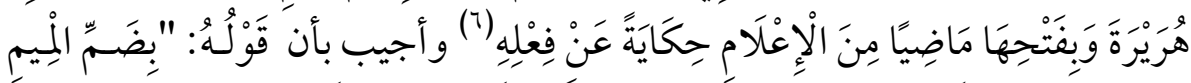

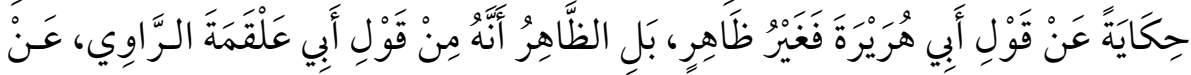

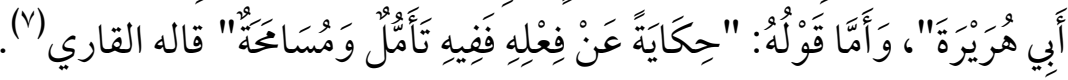

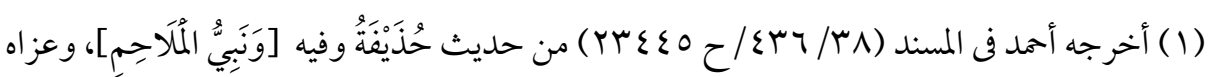

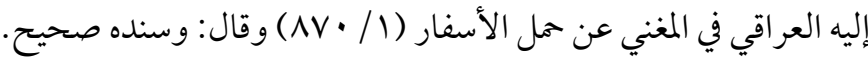

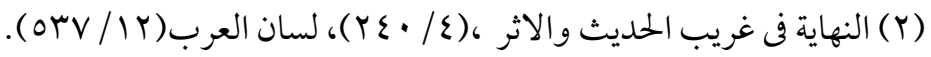

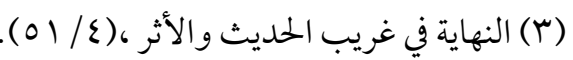

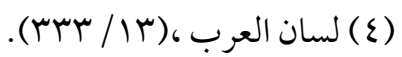

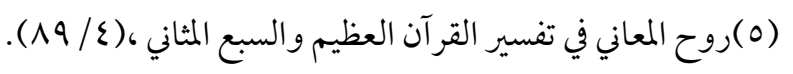

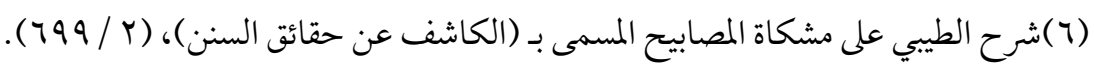

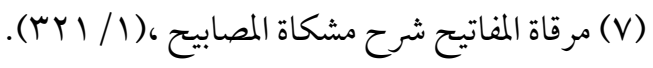




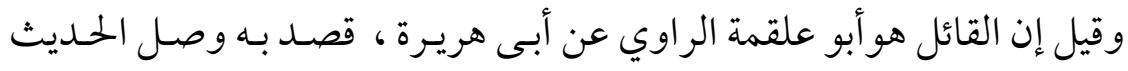

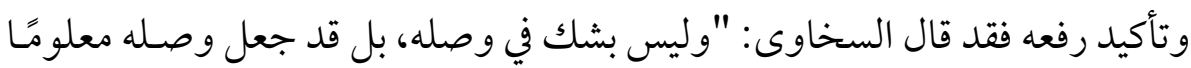

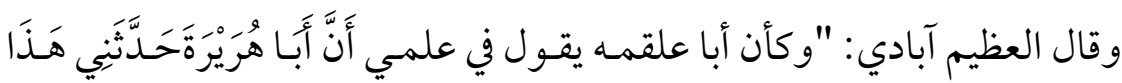

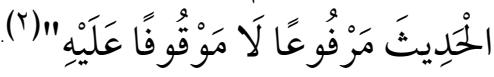

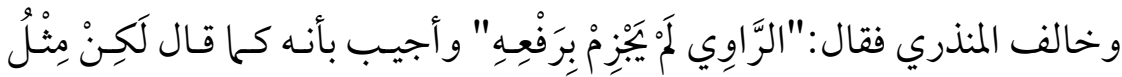

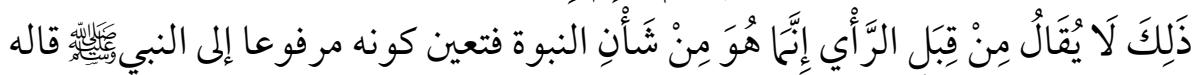

$$
\text { العظيم آبادى (ז). }
$$

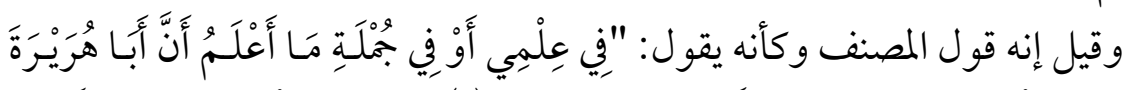

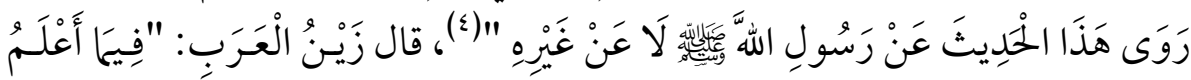

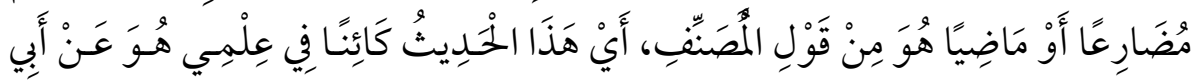

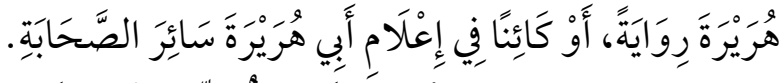

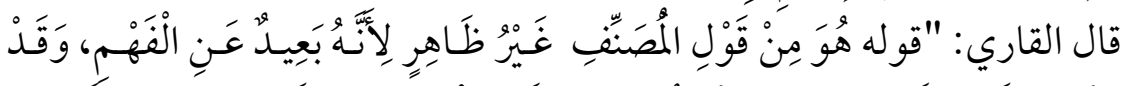

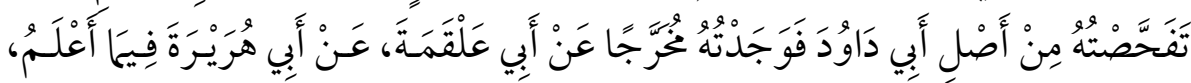

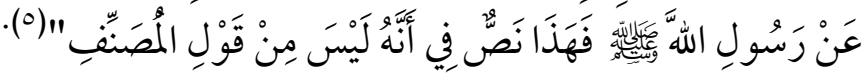

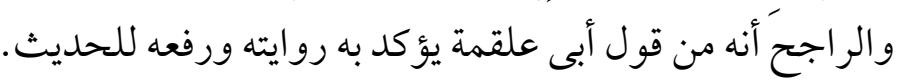

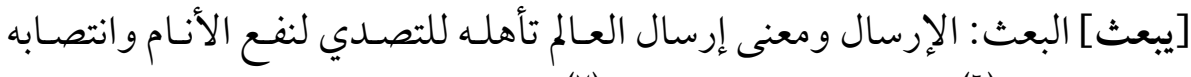

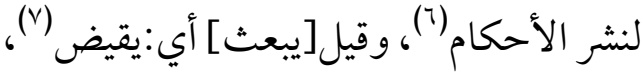
(1) (المقاصد الحسنة، ( / r r (Y).

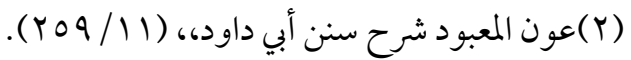

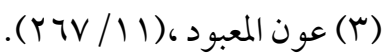

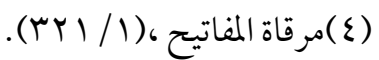

$$
\begin{aligned}
& \text { (0) السابق نفسه. }
\end{aligned}
$$

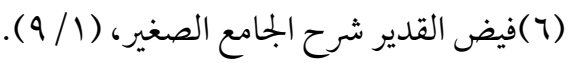

$$
\begin{aligned}
& \text { (YN)/ الفيض، (V) (V) }
\end{aligned}
$$




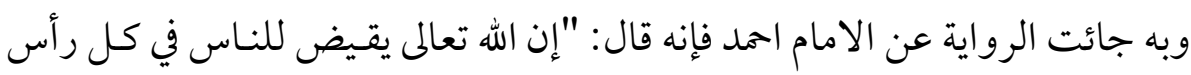

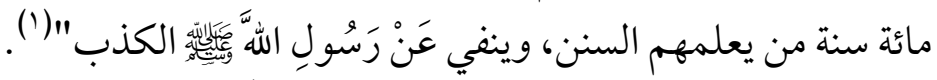

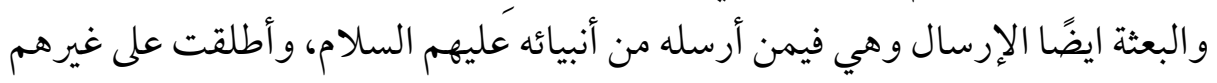

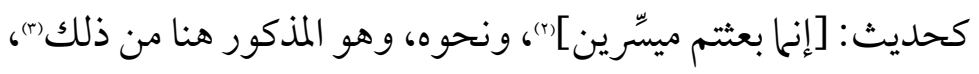

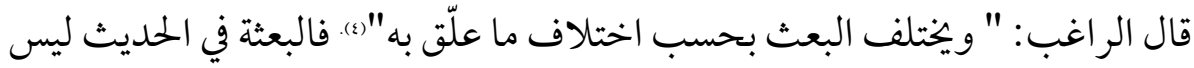

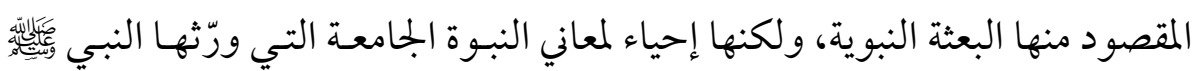
وسلم للعلماء.

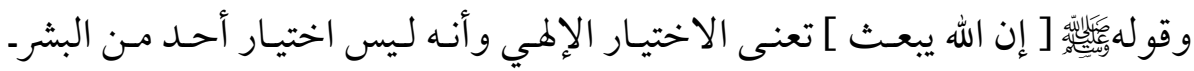

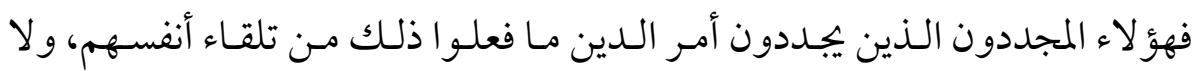

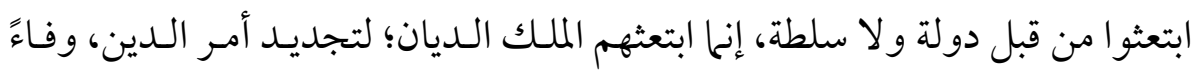

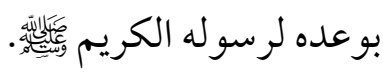

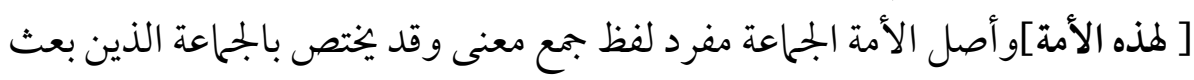

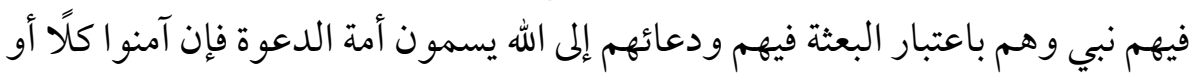

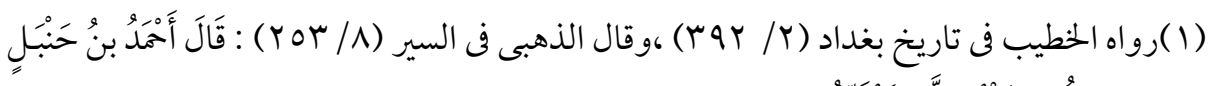

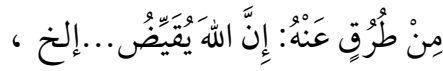

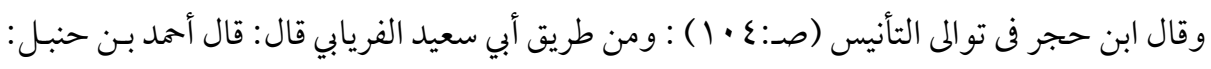

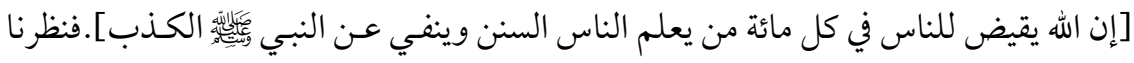

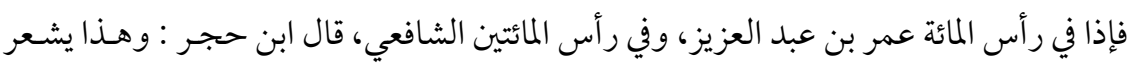

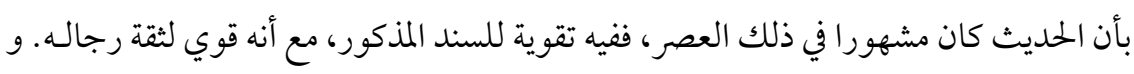

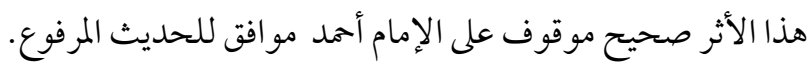

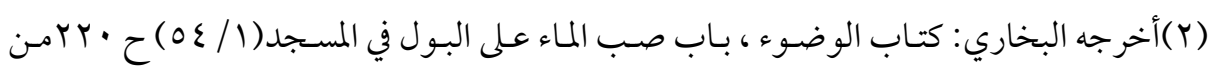

$$
\text { (Y) التويث أبى هريرة. }
$$

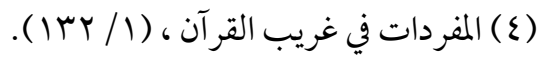


بعضًا سمى المؤمنون أمة إجابة وهم المراد هنا بدليل إضافة الدين إليهم في قولـه [أمـر دينها]

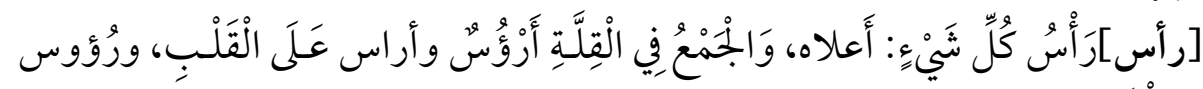
(r) فِي الْكَثِيَ

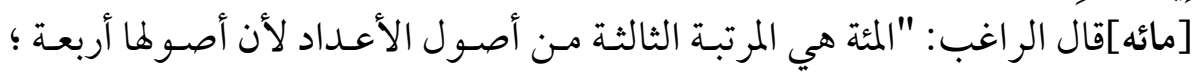

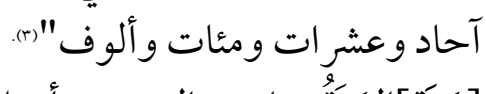

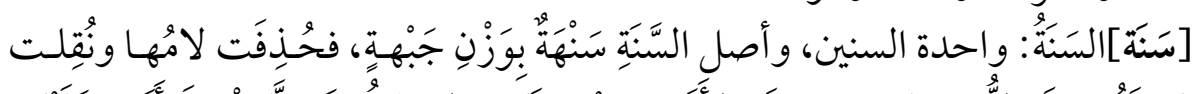

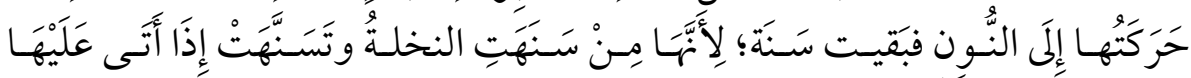

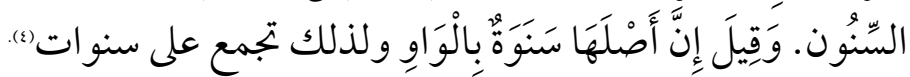

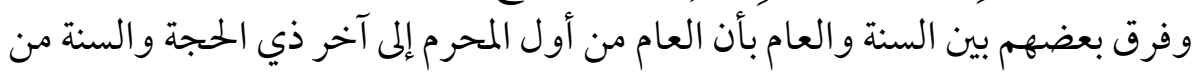
كل يوم إلى مثله من القابلة ذكرهمان

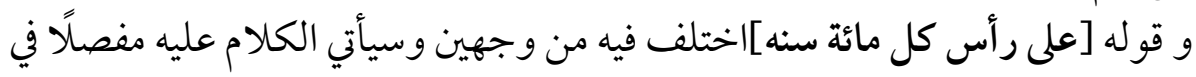

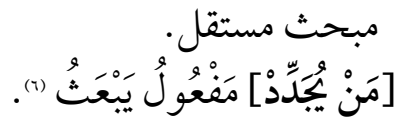

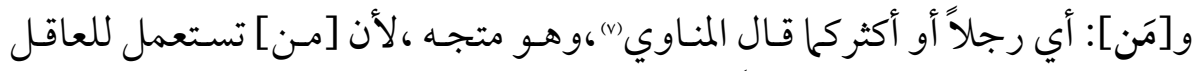

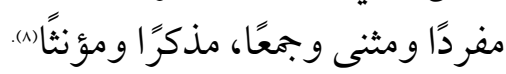

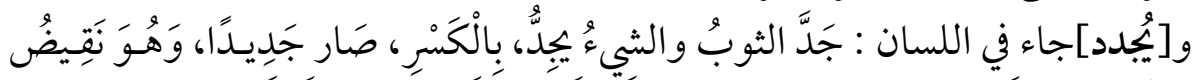

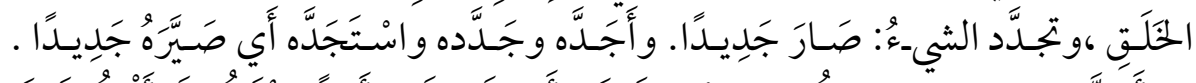

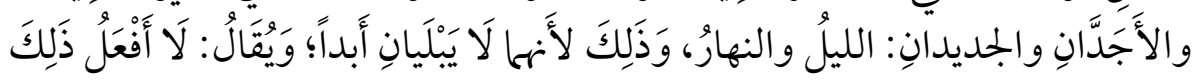

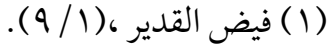

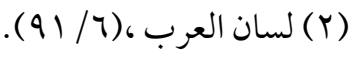

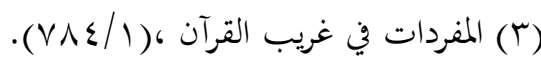

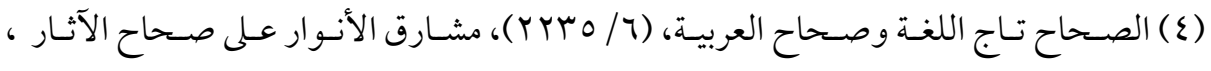

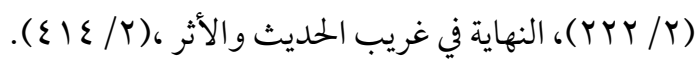

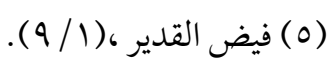

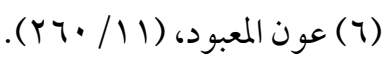

$$
\begin{aligned}
& \text { (YTV/l)، التيسير بشرح الجامع الصغير (V) }
\end{aligned}
$$

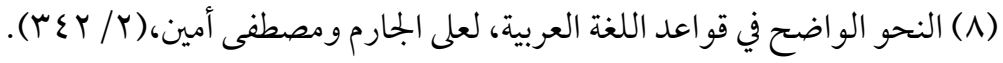




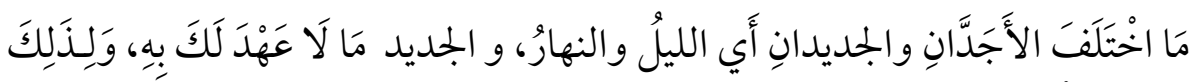

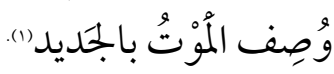

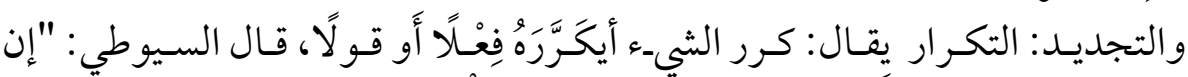

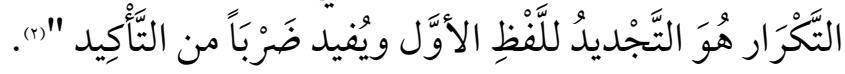

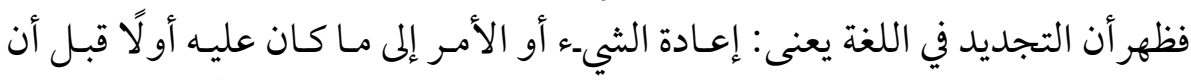

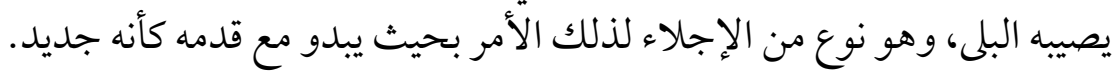

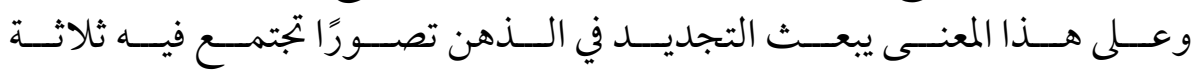

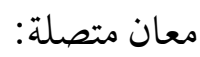

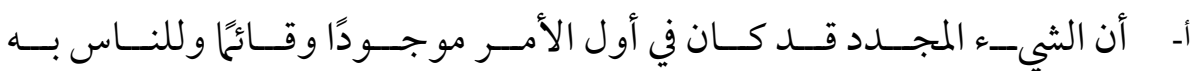
عهد. ب- أن هذا الشىء أتت عليه الأيام فأصابه البلى، وصار قديًًا.

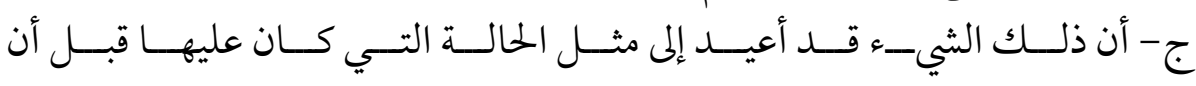
يبلى.

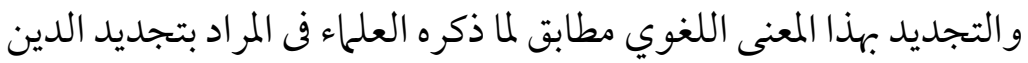

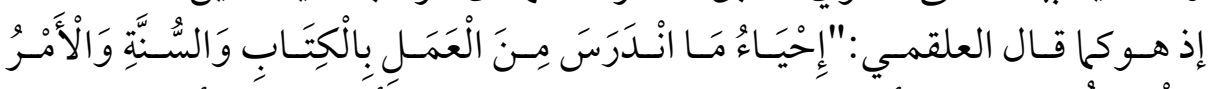

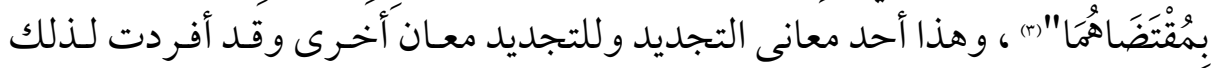
مبحثًا مستقلاً. (s)

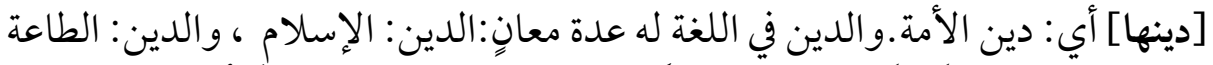

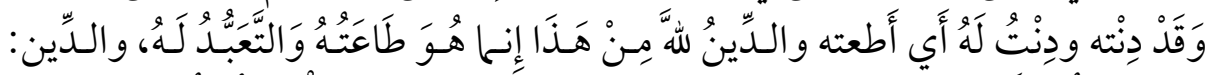

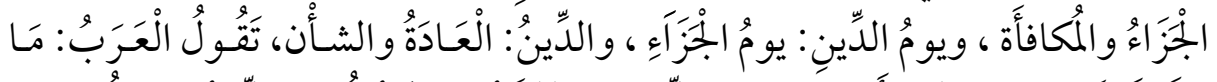

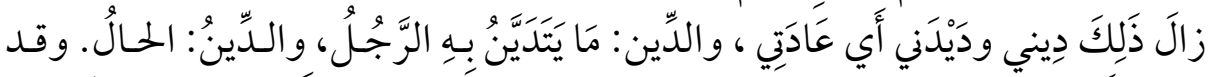

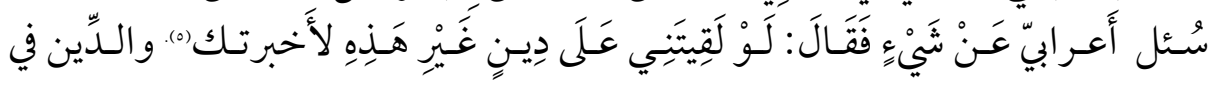

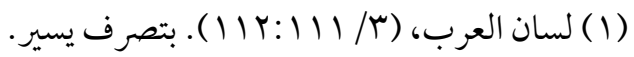

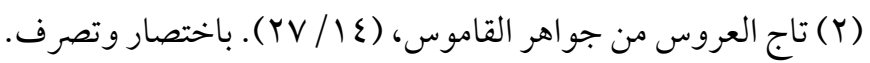

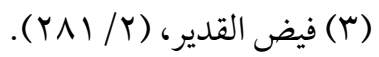

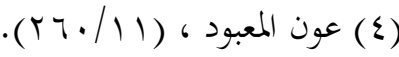

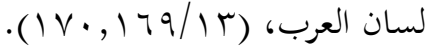


اصطلاح العلماء: "وضع إلهي يدعو أصحاب العقول إلى قبـول مـا هـو عنـد رسـول الله

\section{المعنى العام للحديث}

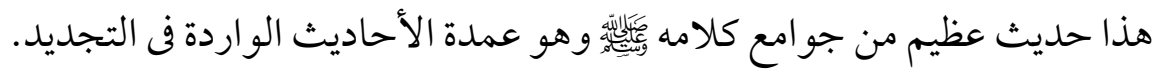

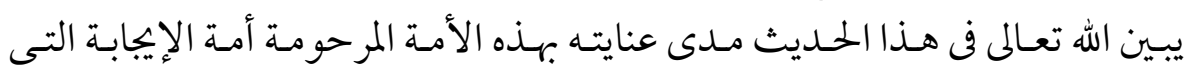

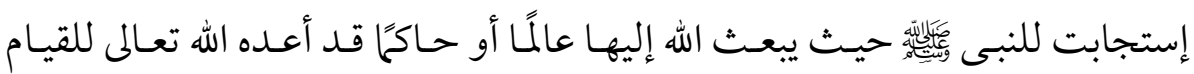

$$
\text { بمهمة التجديد. }
$$

ويكفى هذا المبعوث شرفًا أن الذى يتولى إعداده وإرساله هـو الله رب العـالمين وأن الله

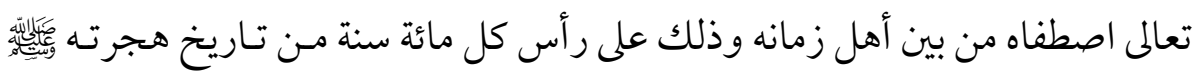
على الراجح. فى أول المائة أو آخرها أو على الدوام فئ ودئ سائر السنين والأيام وأنه سبحانه

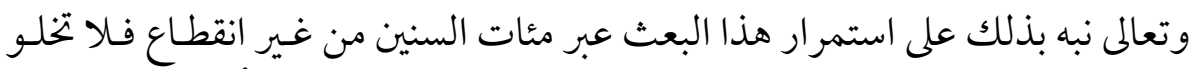

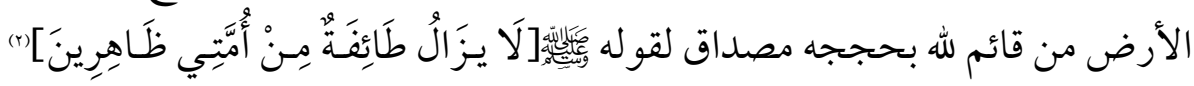

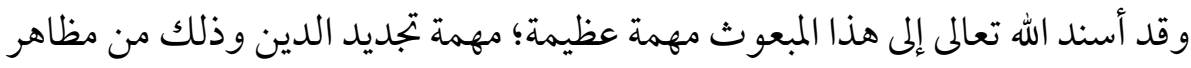

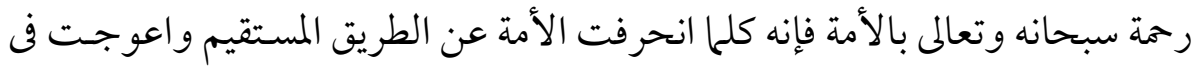
سيرها لا يتر كها الله سبحانه وتعالى تتلاعب بها الأهو اء بل يبعث إليها حينئذٍ من يقوم إعوجاجها ويقيل عثراتها ويبعثها من رقادها ويردها إلى أصل الدين.

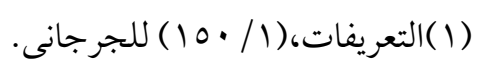

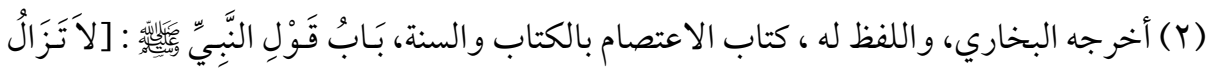

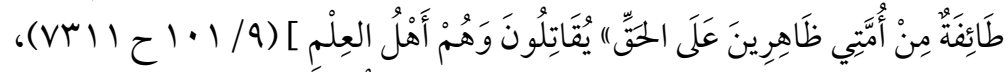

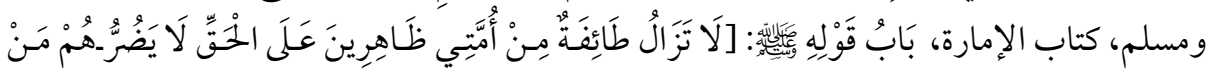

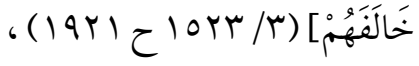

$$
\begin{aligned}
& \text { من حديث المغيرة بن شعبة. }
\end{aligned}
$$




\section{المبحث الأول \\ معنى التجديد وحقيقته}

في الحديث دلالة على تجديد الدين وقد حظيت هذه الدلالة بإعتناء العلماء بيانًا

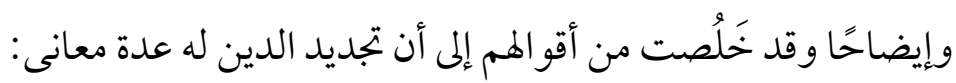

إحداها:

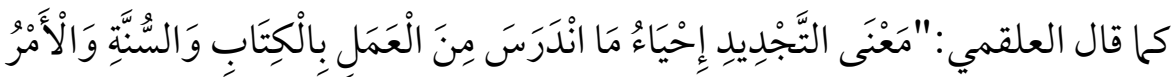

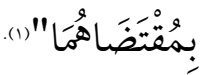

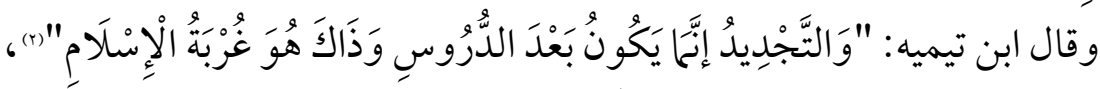

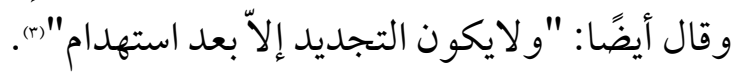

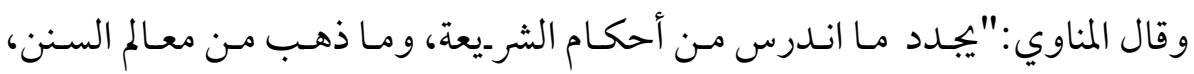
وخفي من العلوم الدينية الظاهرة والباطنة"(s).

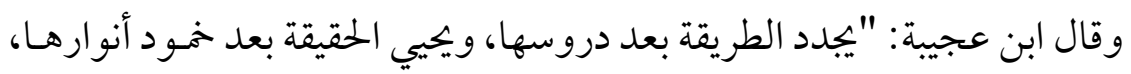

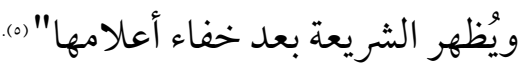

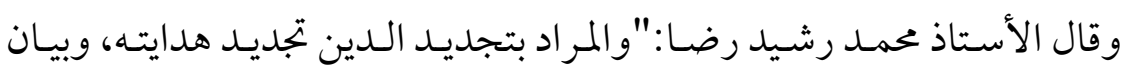

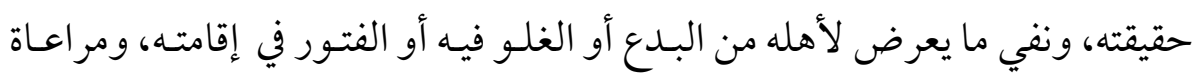

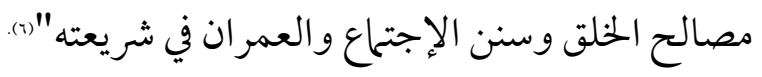

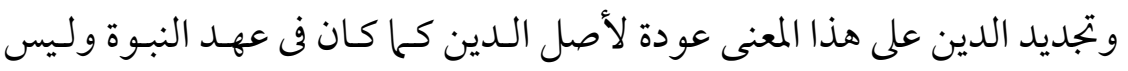

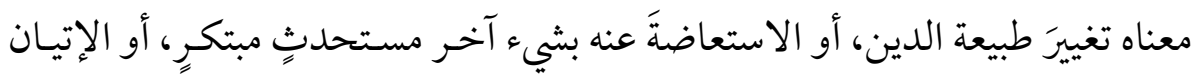

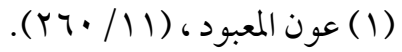

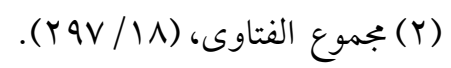

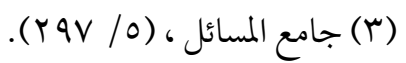

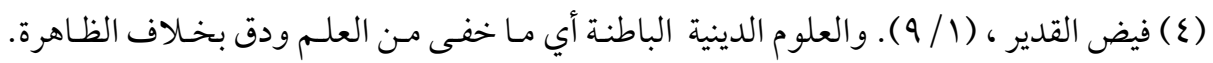

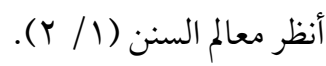

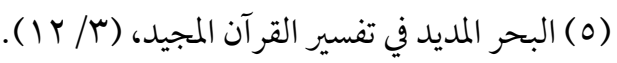

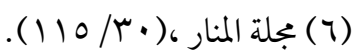




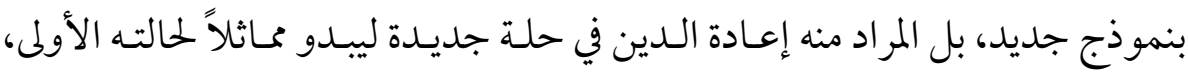

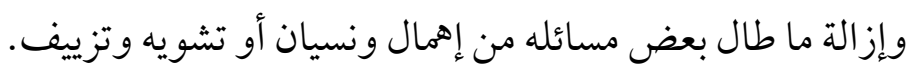

ثانيها:

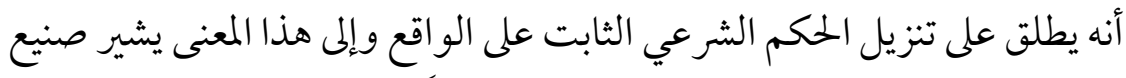

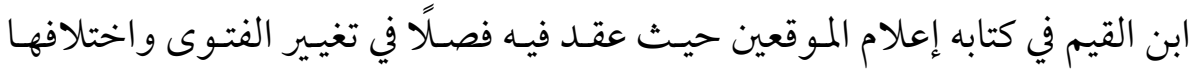

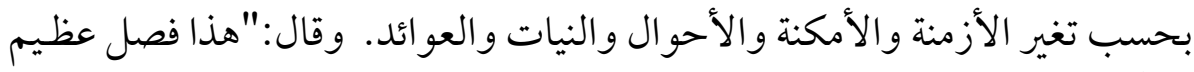

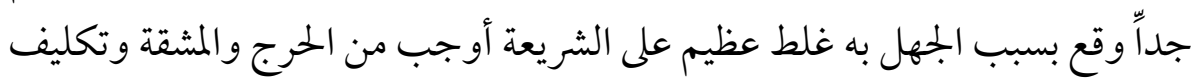

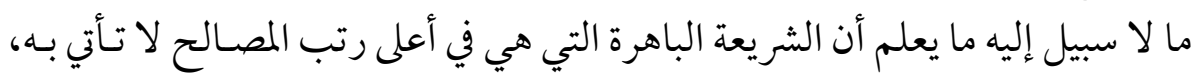

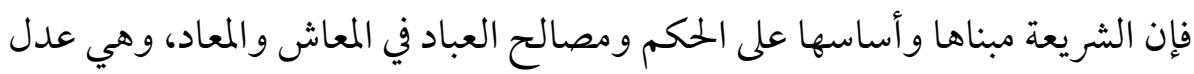

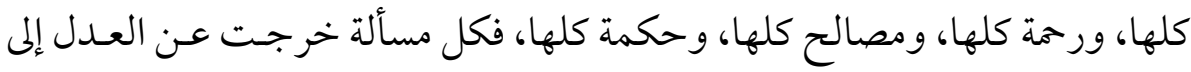

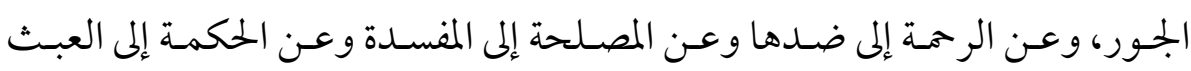

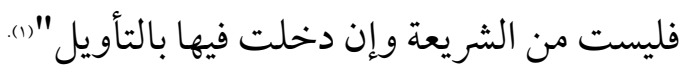

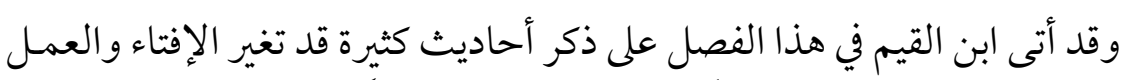

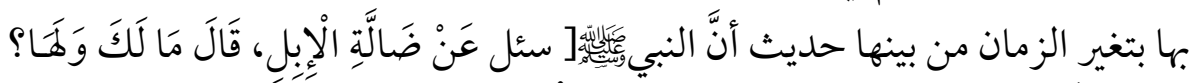

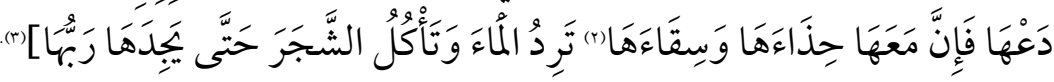

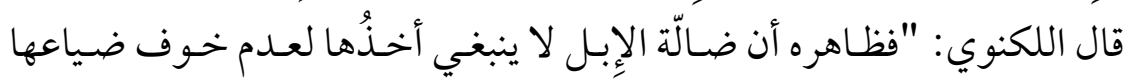

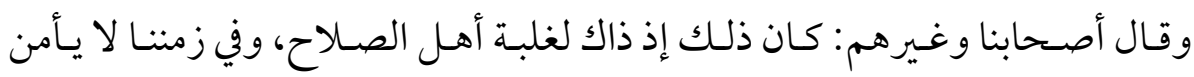

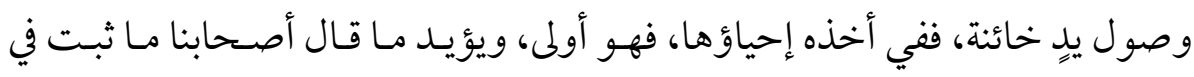

$$
\text { (1) (1) إعلام الموقعين عن رب العالمين، (T/ (1) ). }
$$

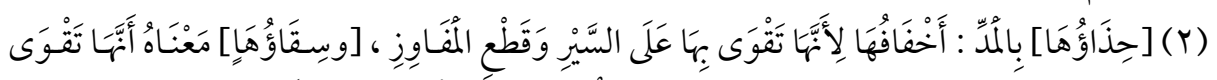

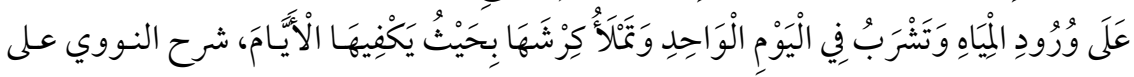

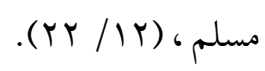

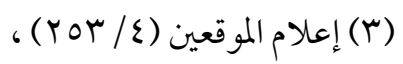

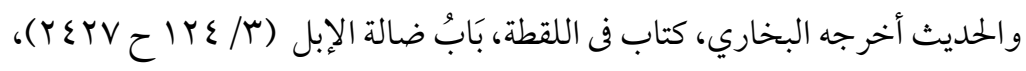

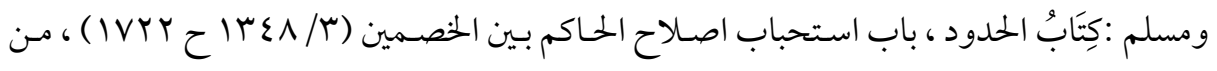
حديث زيد بن خالد الجهنى. 
زمان عثمان لانقلاب الزمان حيـث أمـر بتعريفها بعـد التقاطها خوفـاً مـن الخيانة ثم

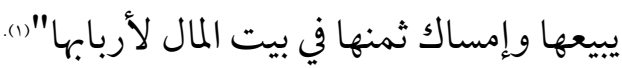

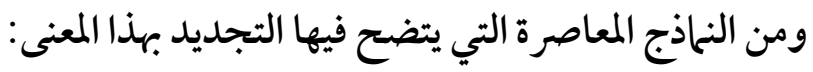

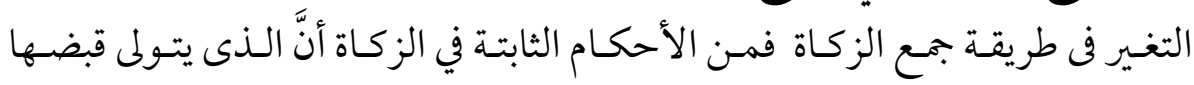

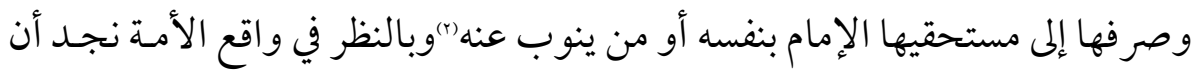

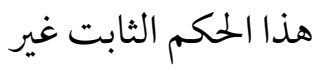
معمول به ، وإزاء هذا الوضع الذى تعطلت فيه هذه الوظيفة الأساسية للدولـة، اتجه. كثير من صلحاء الناس ووجهائهم إلى تشكيل جمعيات ومؤسسات للقيام بهذه المهمـة

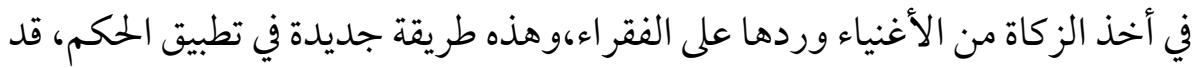

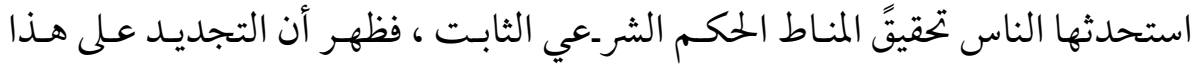

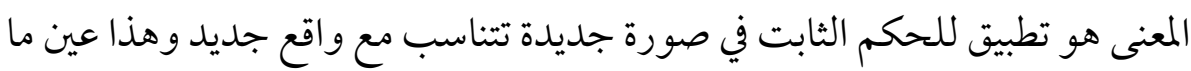

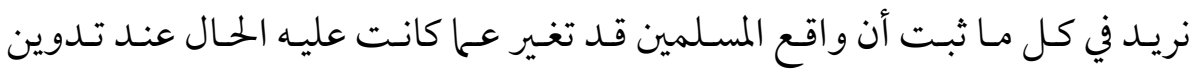
الأحكام أو الفتاوى الشرعية.

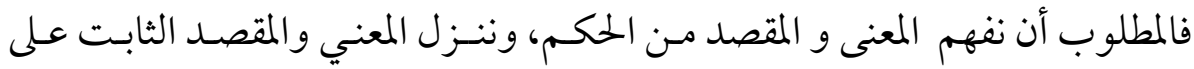

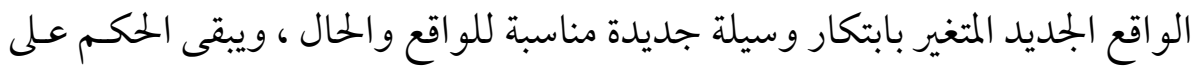

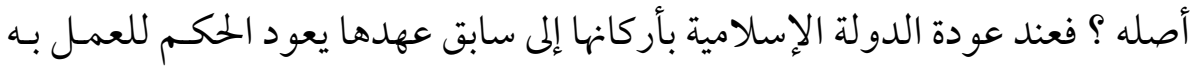

$$
\text { فيقوم الإمام بجمع الزكاة وصرفها. }
$$

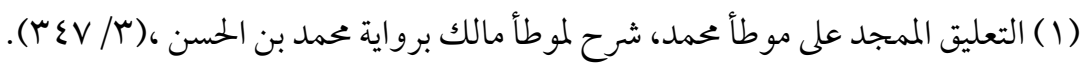

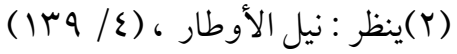


الإجتهاد: "وهو أهلية وملكة يقتدر بها المجتهد على فهم النصوص واستثمار الأحكام (1)" الشرعية منها

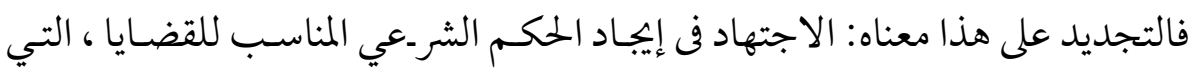

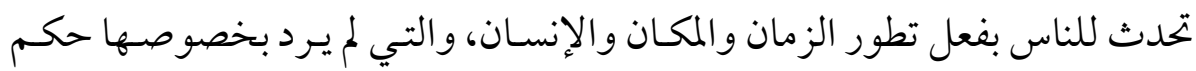

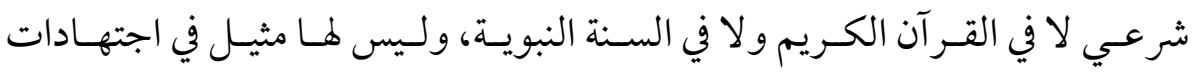
السابقين. ومعن أطلق التجديد على الاجتهاد الإمام السيوطي والمناوى:

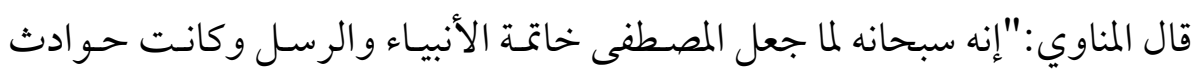

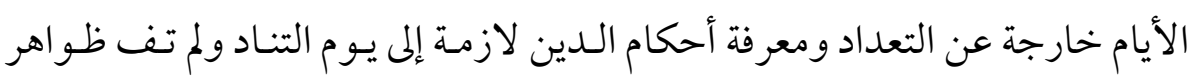

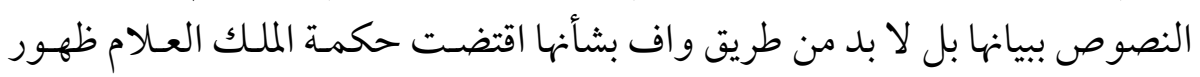

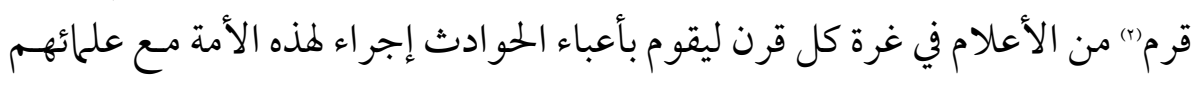

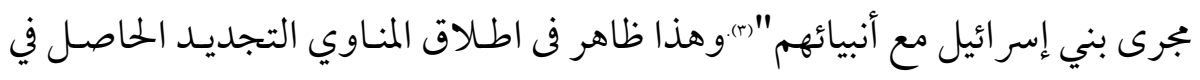
أول كل قرن على الاجتهاد.

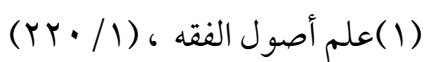

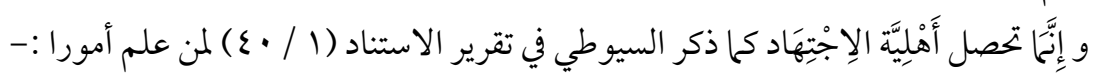

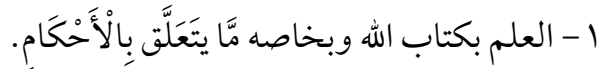

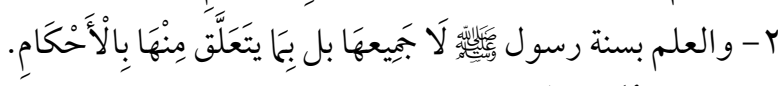

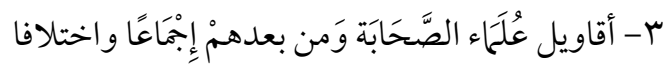

$$
\begin{aligned}
& \text { ع - و علمه بالقياس. }
\end{aligned}
$$

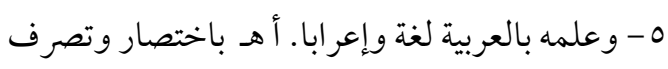

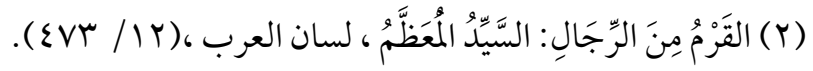

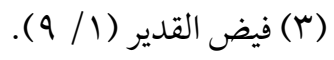




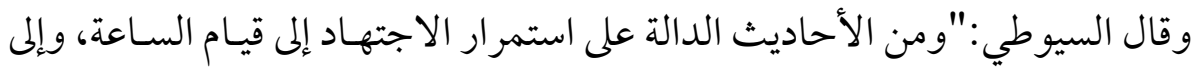

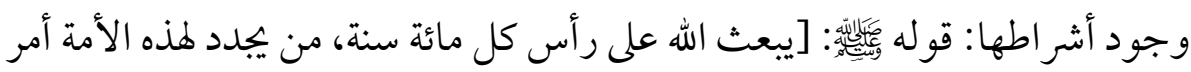
دينها]" (1).

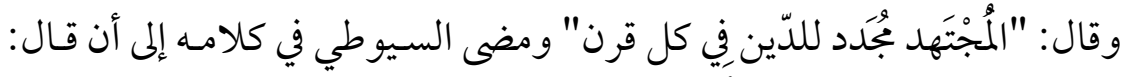

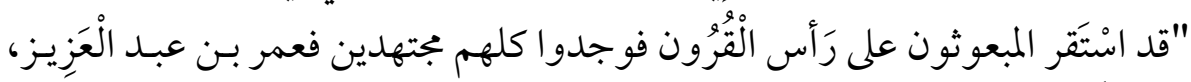

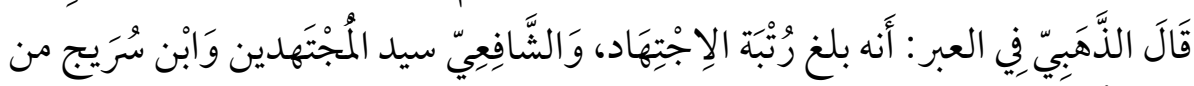

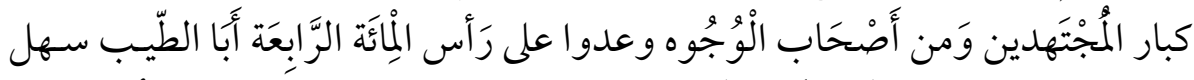

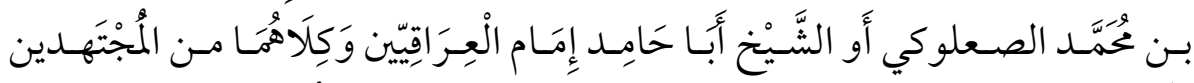

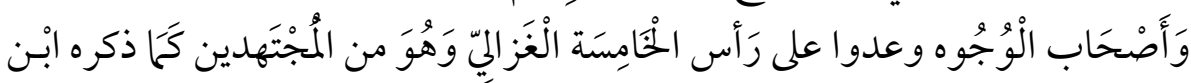

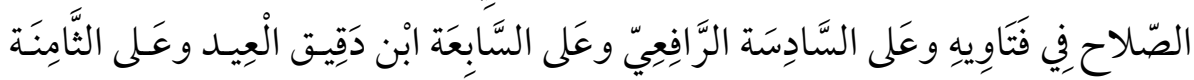

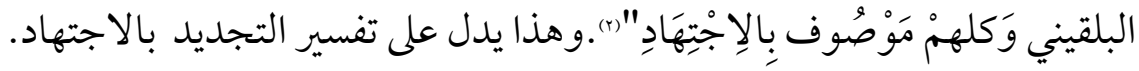

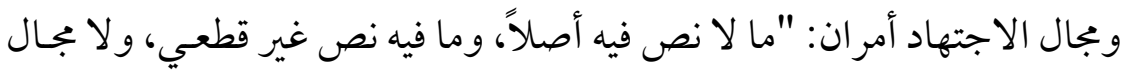

$$
\text { للاجتهاد فيما فيه نص قطعي" آلمال. }
$$

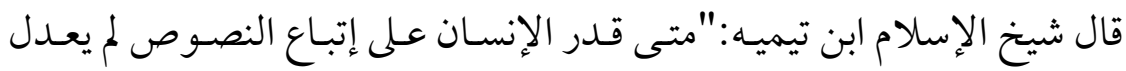

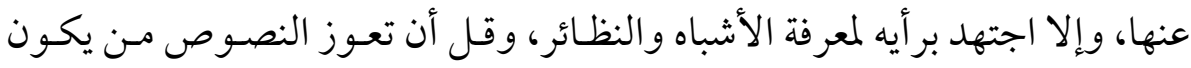

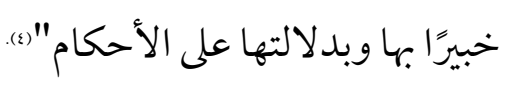

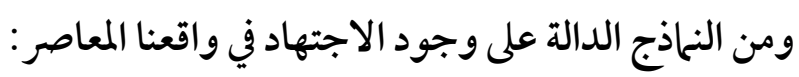

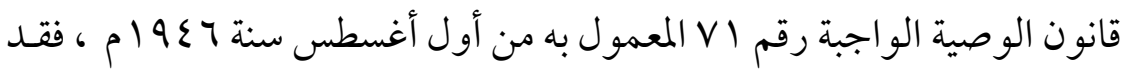

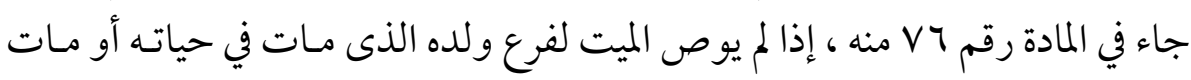

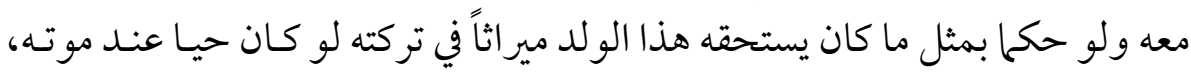

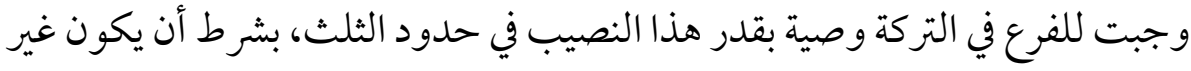

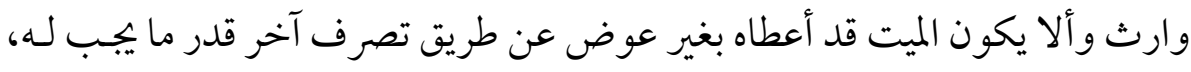

$$
\begin{aligned}
& \text { (1) (1) تقرير الاستناد في تفسير الاجتهاد (1 / عهo ). }
\end{aligned}
$$

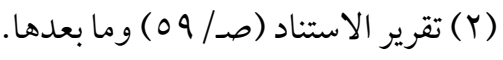

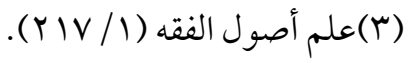

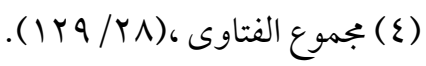




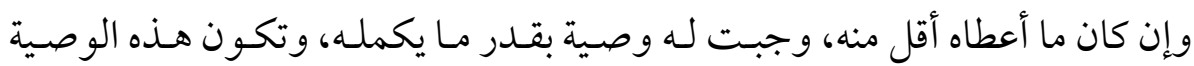

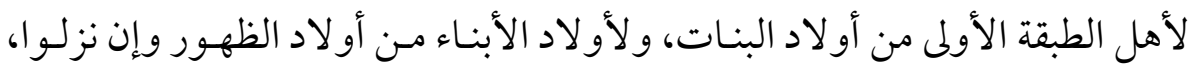

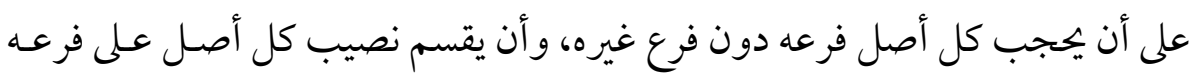

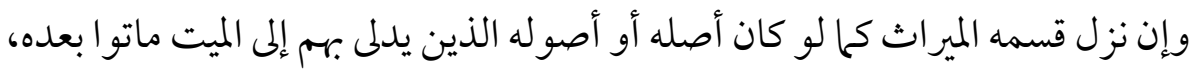

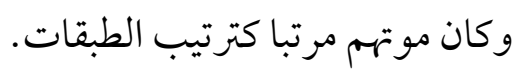

وقد أفصحت المذكرة الإيضاحية لقانون الوصية عما استهدفه هذا النص وتغيات الطياه فقالت

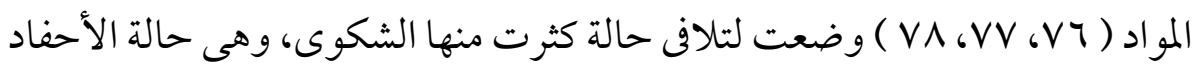

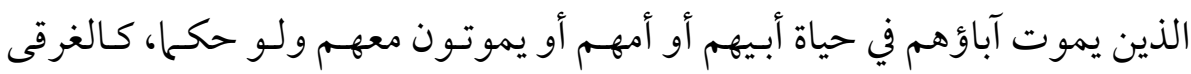

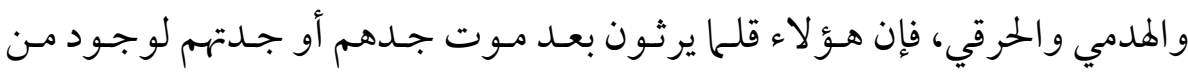

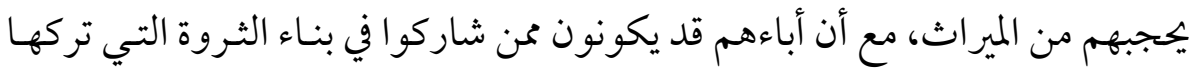

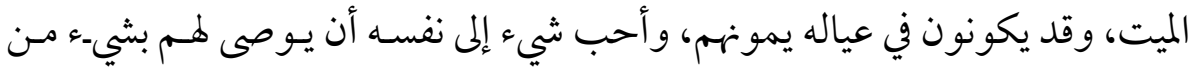

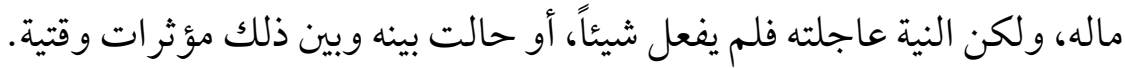

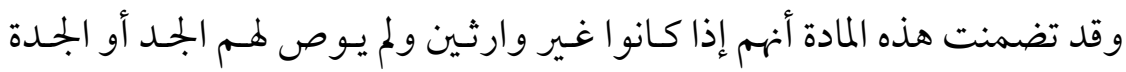

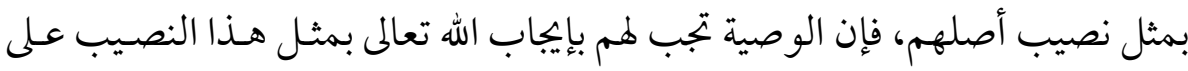

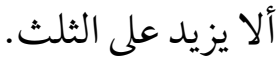

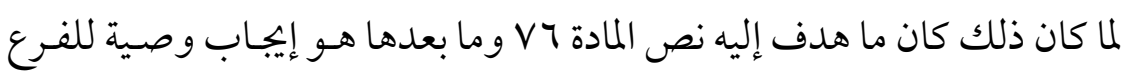

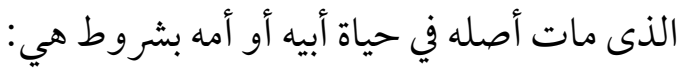

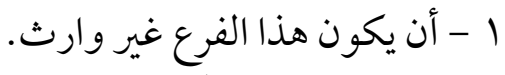

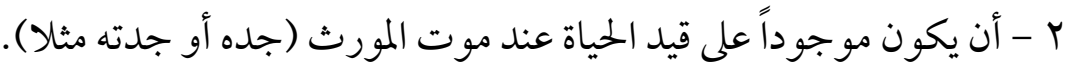

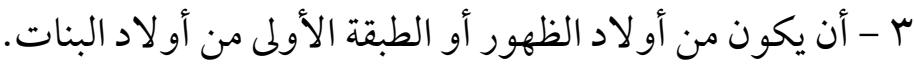

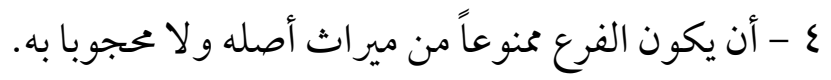

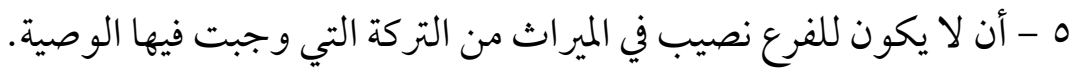

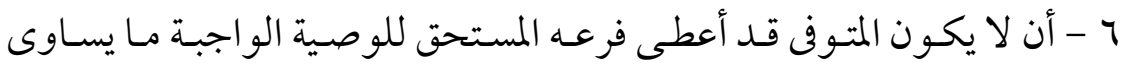

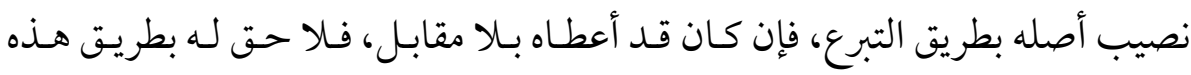
الوصية إلا إذا كان ما أخذه أنقص من استحقاقه فيستكمل له. 
وهذا القانون إنها هو اجتهاد معناه المصلحة في نطاق القدر الذى تجوز الوصية به،

$$
\text { وتُنَفَذ بدون توقف على موافقة الورثة. }
$$

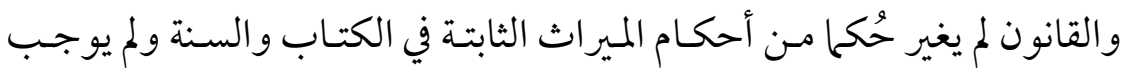

$$
\text { الوصية إلا للفرع غير الوارث(1). }
$$

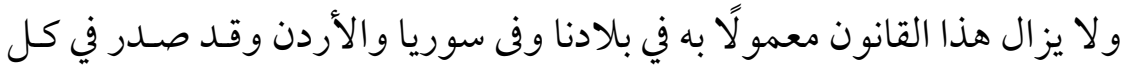
منها قانون على غرار القانون المصري.

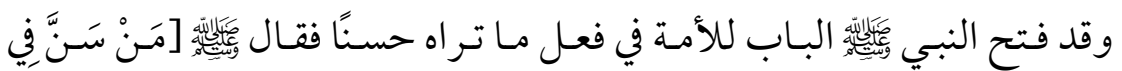

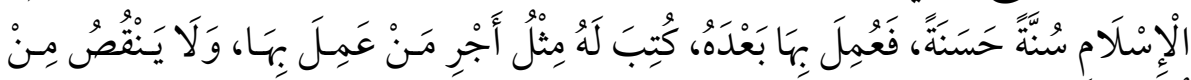

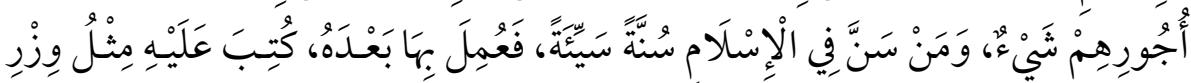

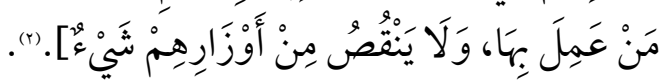

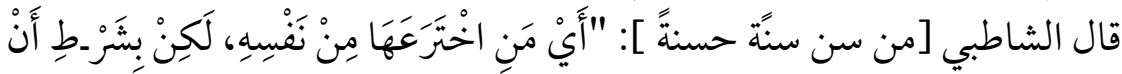

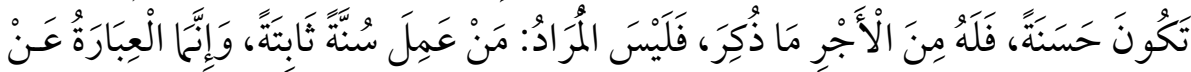

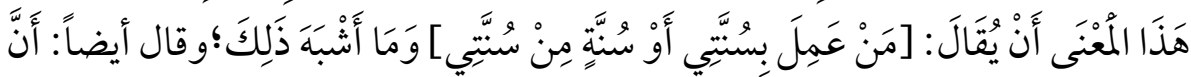

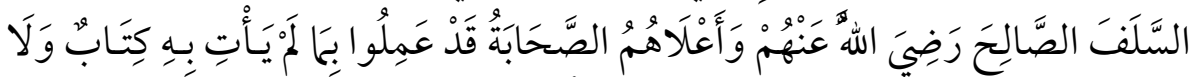

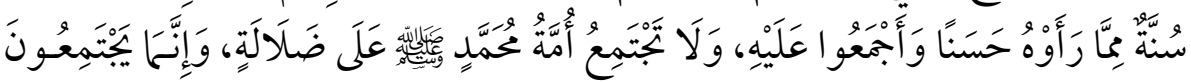

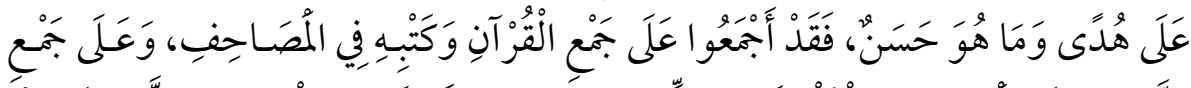

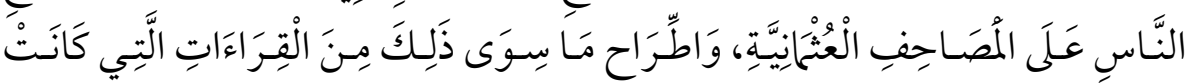

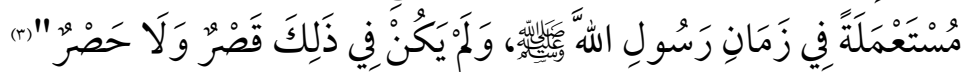

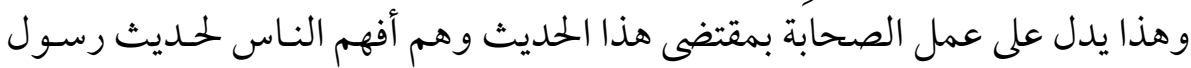
الله وقد اقتدى بهم من جاء من بعدهم من علم)ء الأمة وعملو ا بمقتضى هذا الحديث أيضًا

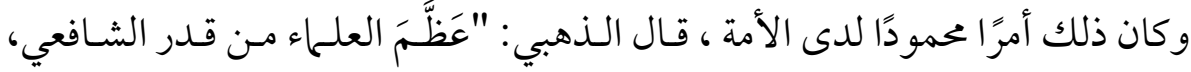

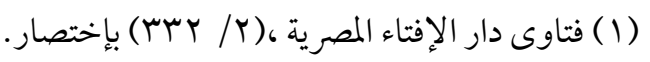

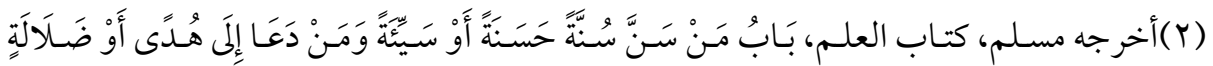

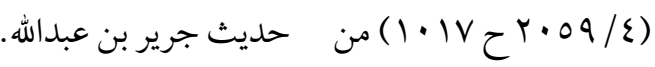

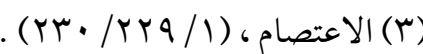




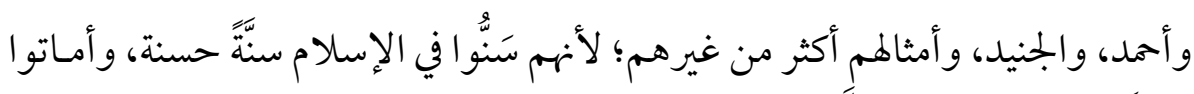

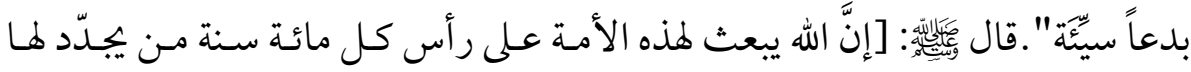
دينها]" (1)

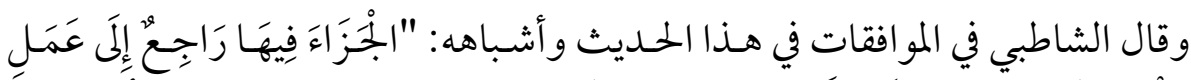

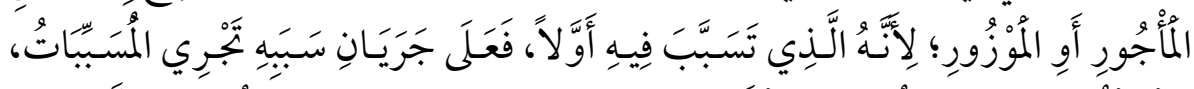

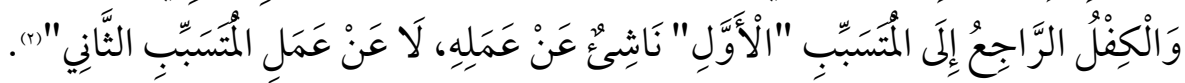

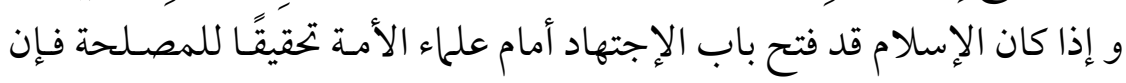

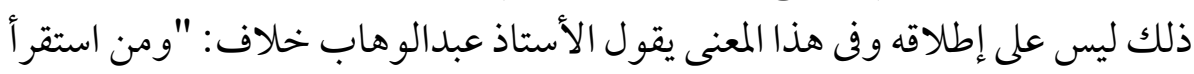

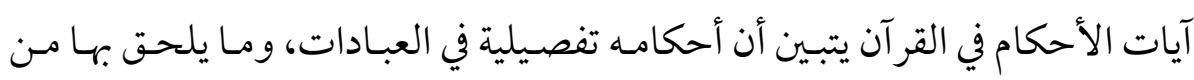

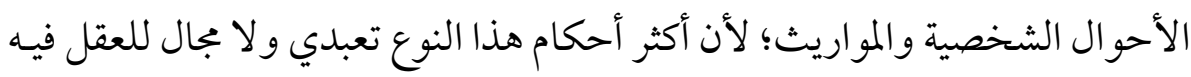

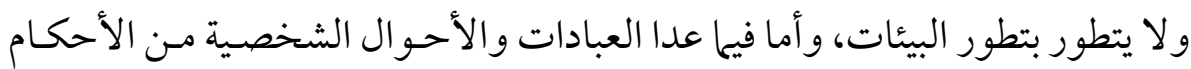

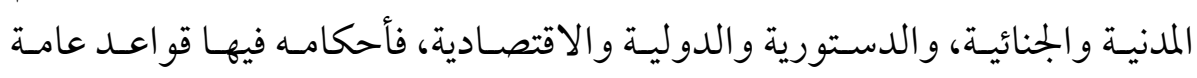

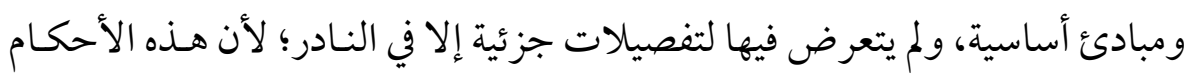

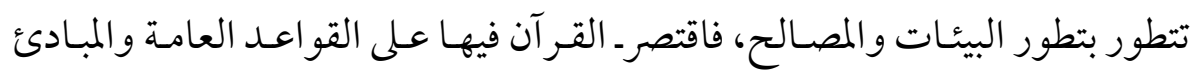

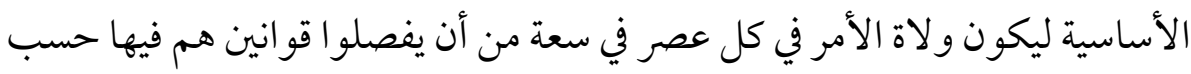

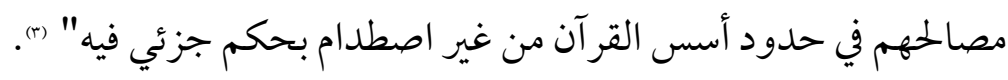
قال الأستاذ عحمد رشيد رضا:

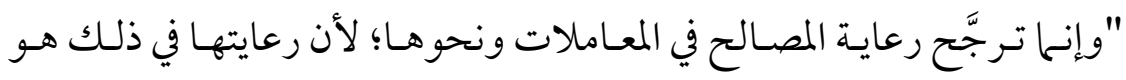

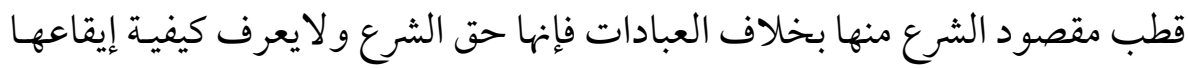

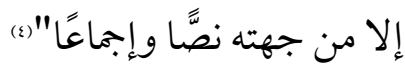

$$
\begin{aligned}
& \text { ( (1) التمسك بالسنن و التحذير من البدع، (1 / V • (1). }
\end{aligned}
$$

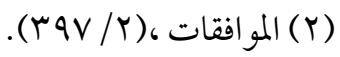

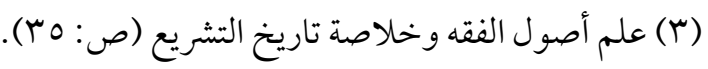




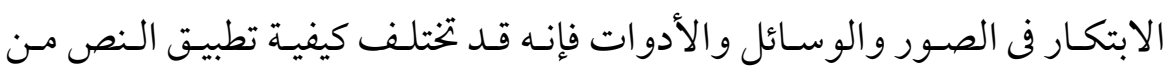

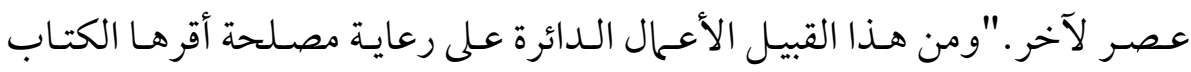

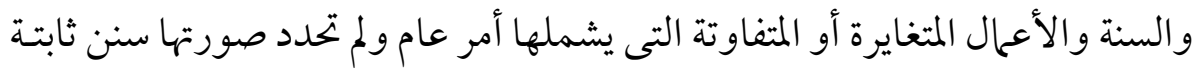

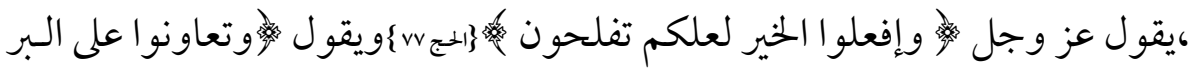

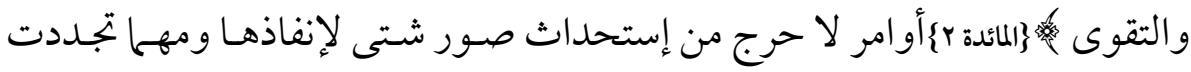

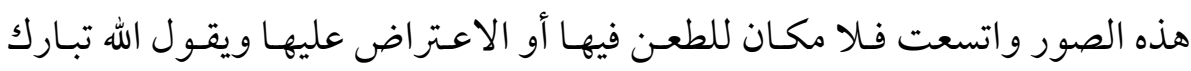

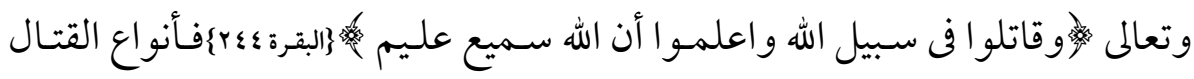

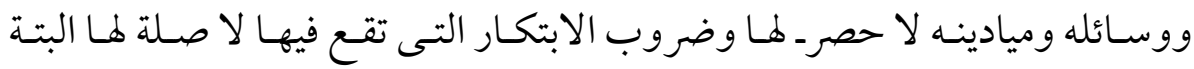

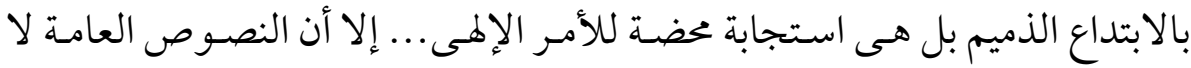

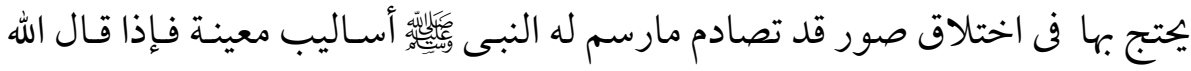

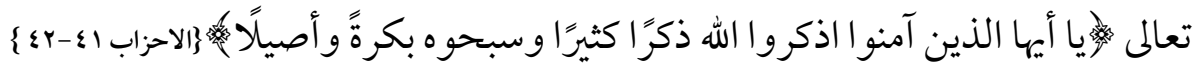

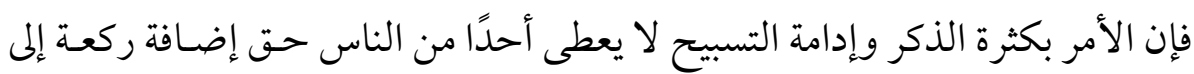

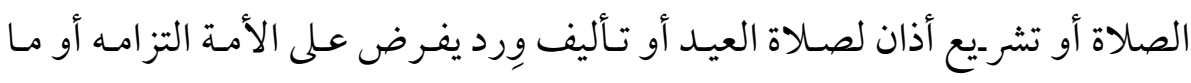

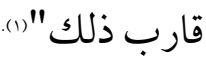

ويدخل في التجديد إحياء التراث ونشر ـالكتـب الدينيـة وتقريبهـا للأمـة وقـد ذكر

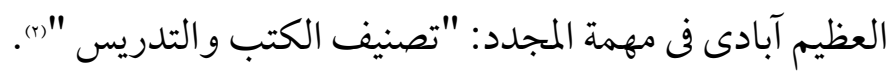

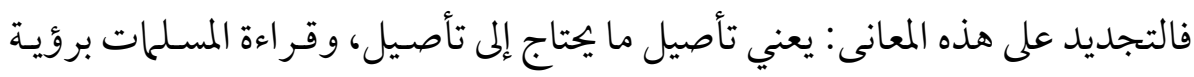
جديدة، وإحياء الفكر الديني بها يتناسب مع لغة العصر، والاجتهاد من من داخل مالميل الـدليل

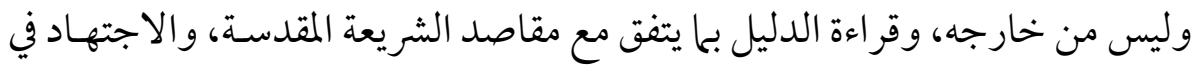

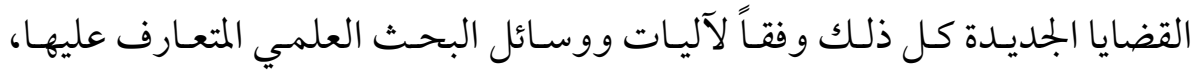

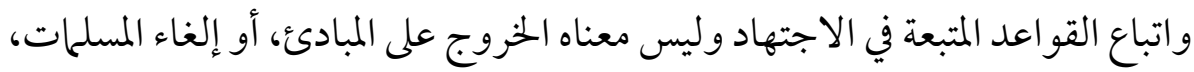
أو إبطال الأحكام الشرعية، أو التفكير بعيداً عن روح الميعة ولنيس النصوص.

$$
\begin{aligned}
& \text { (1) كتاب : ليس من الاسلام للشيخ محمد الغزالى ، (1/1) ع99 ). }
\end{aligned}
$$

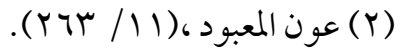


وقد جاء في فتاوى دار الإفتاء المصرية مـا نصه:"أقر الإسلام التجديد في نطاق

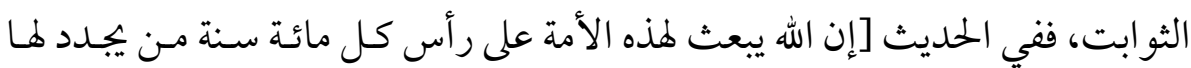
دينها:[")

وأما تغيير النصوص لصالح الو اقع، أو تفسيرها تفسيرًا غريبًا عن مفهومها ومنطوقها،

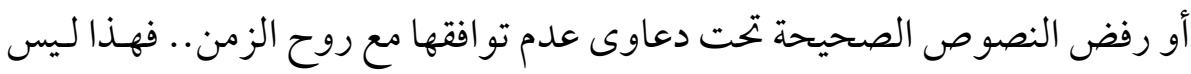

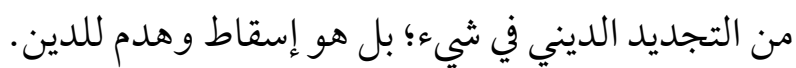

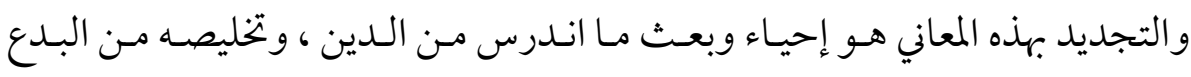

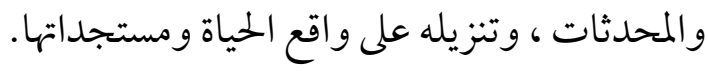




$$
\text { المبحث الثانى }
$$

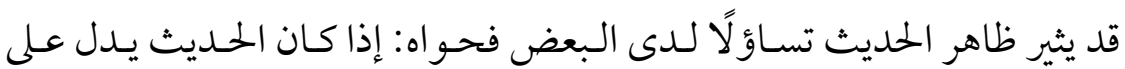

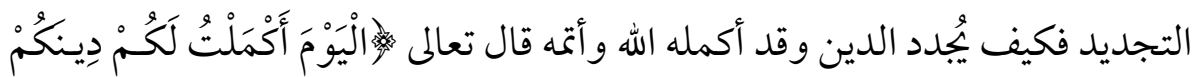

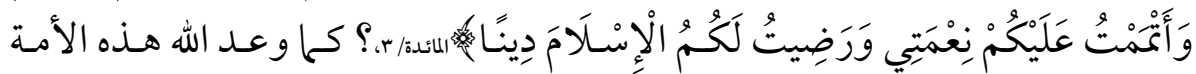

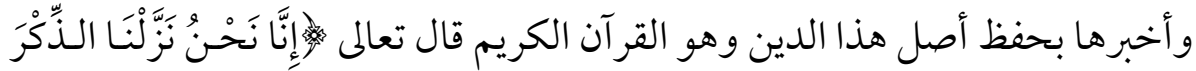

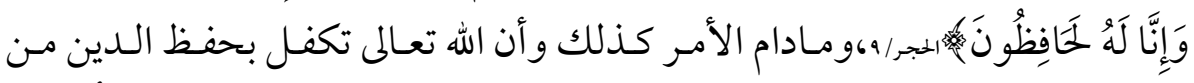

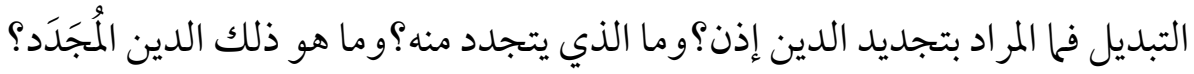

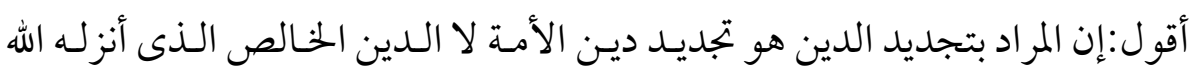

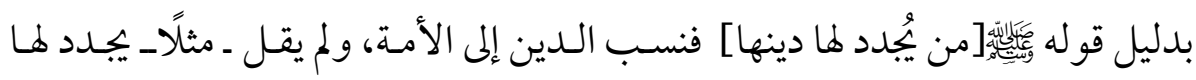
الدين أو يجدد لها دين الله. ومن صرح بذلك المباركفورى فقال: "المرادمن تجديد الميد الدين للأمة إحياء مـا اندرس

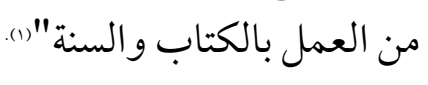

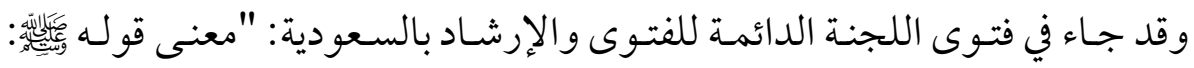

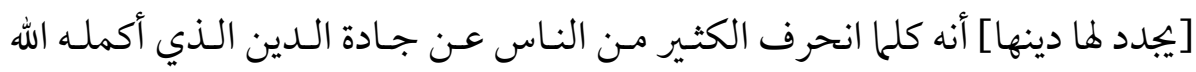

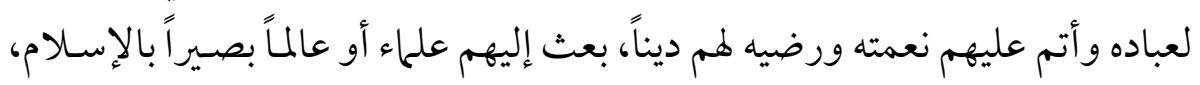

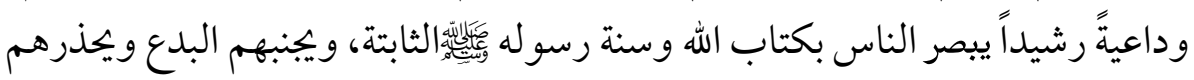

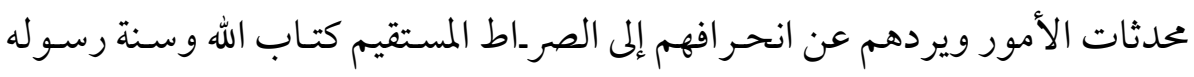

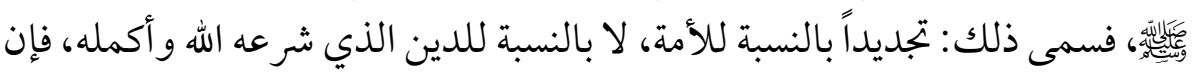

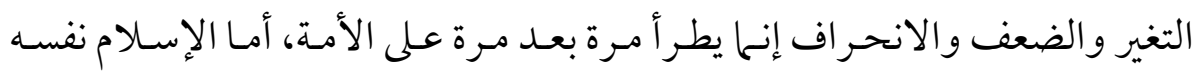

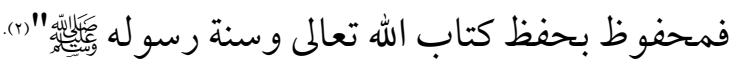

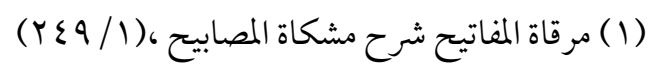

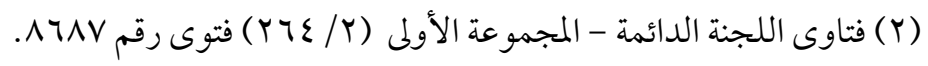

$0 . \leqslant$ 


$$
\text { و التجديد لدين الأمة هو الذى دلت عليه أقو ال العلماء: - }
$$

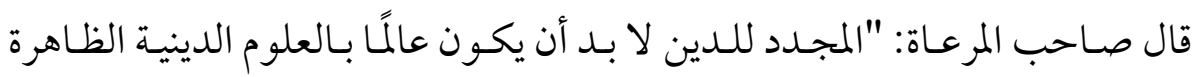

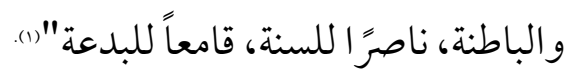

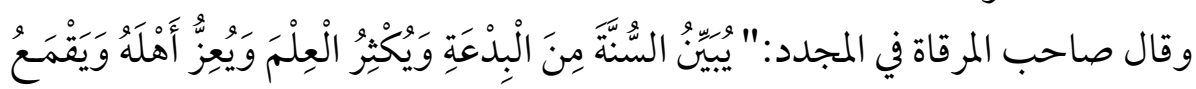

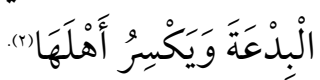
وقال صاحب الفيضأيضاً: "يبين السنة من البدعة ويكثر العلـم وينصرـ أهله ويكسر-

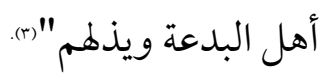

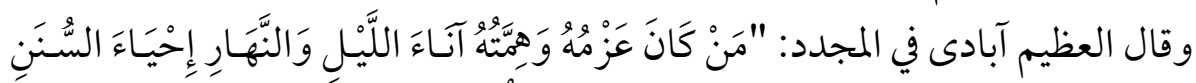

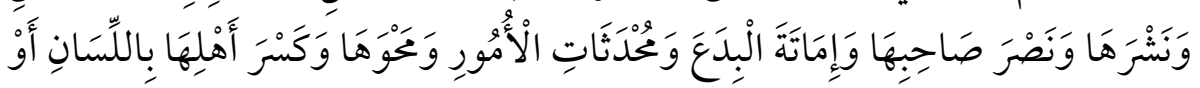

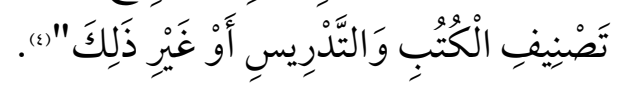

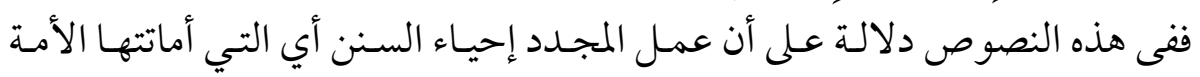

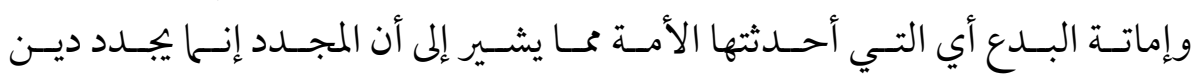

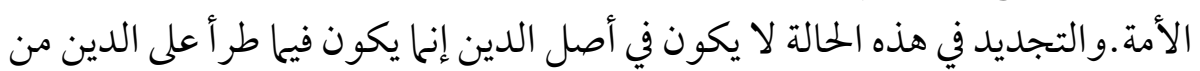

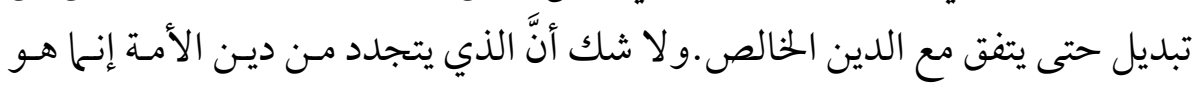

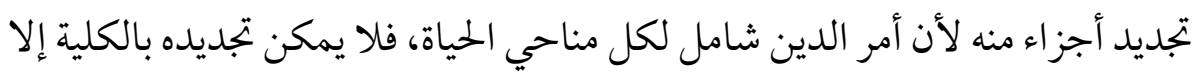

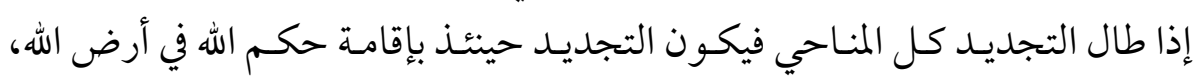

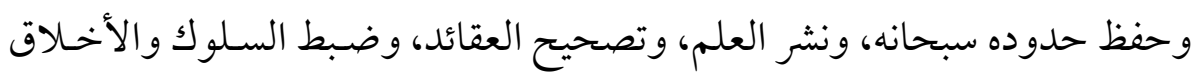

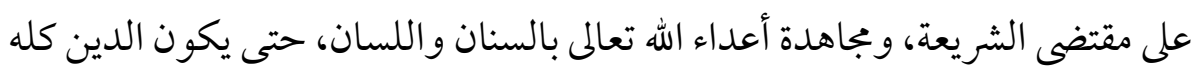

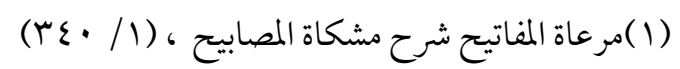

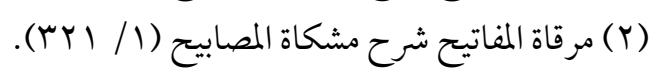

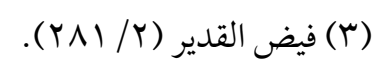

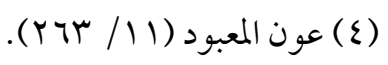

0.0 


\section{المبحث الثالث \\ حاجة الأمة إلى التجديد}

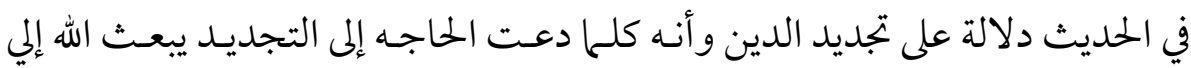

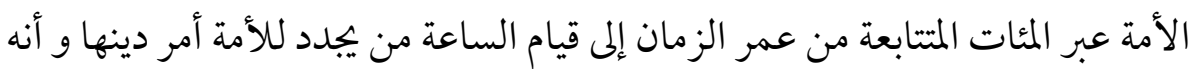

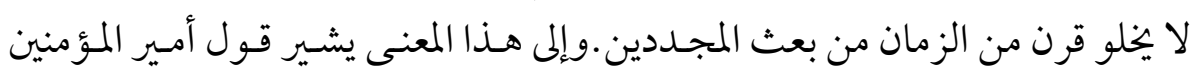

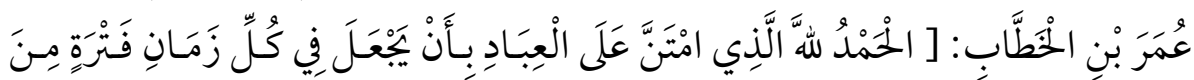

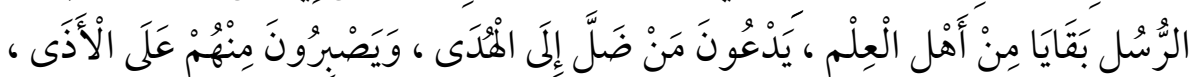

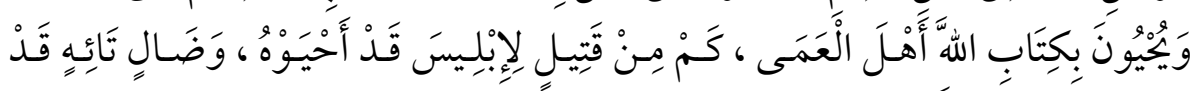

(1)

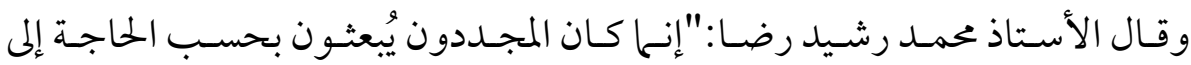

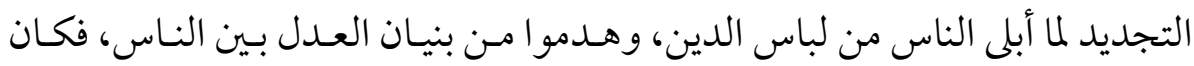

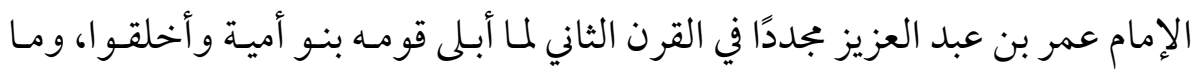

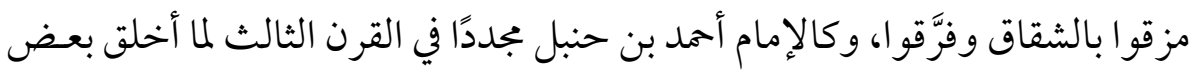

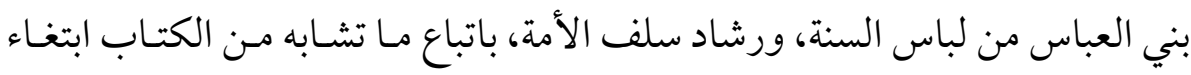

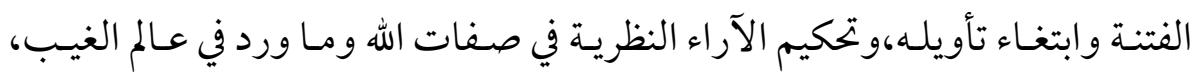

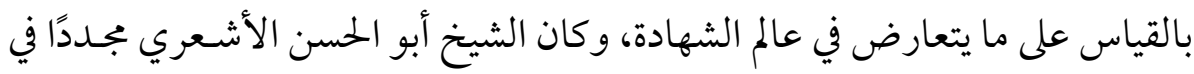

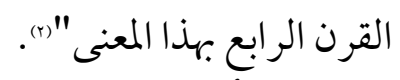

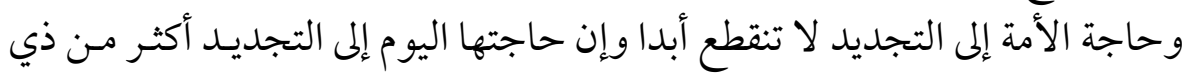

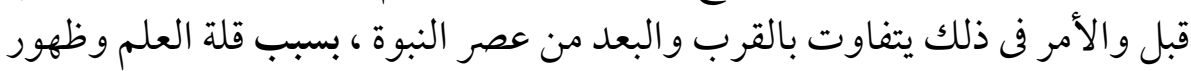

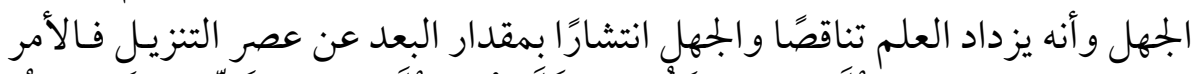

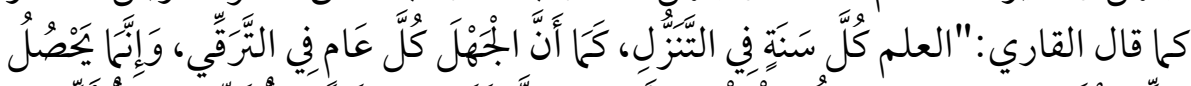

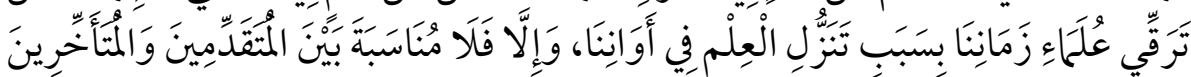

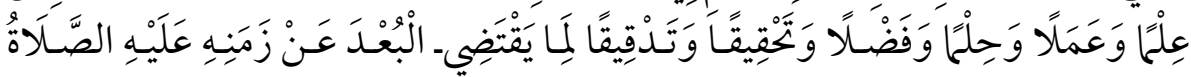

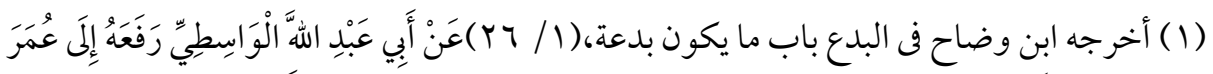
بْنِ الْنَطَّابِب.

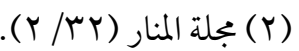




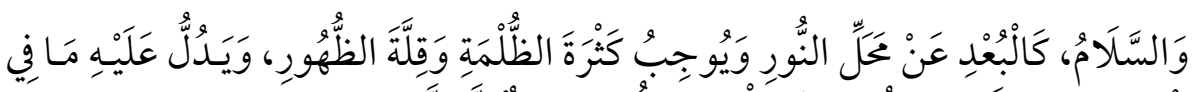

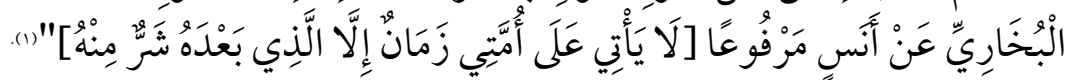

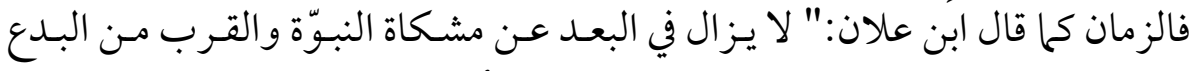

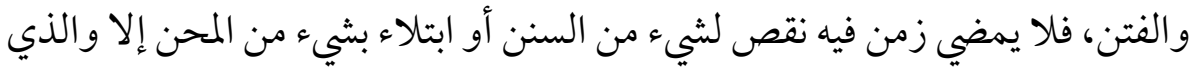
بعده أشد منه في ذلك" "(i).

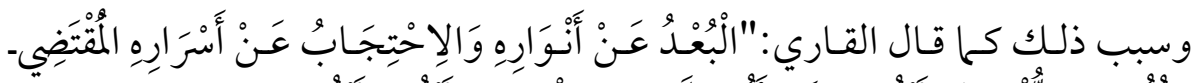

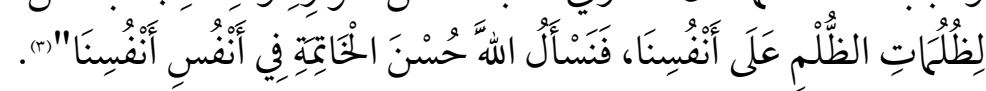

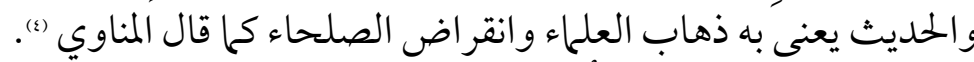

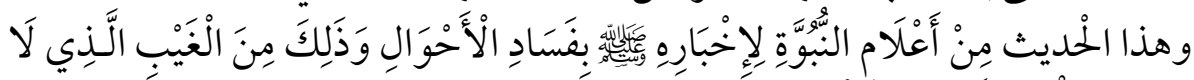

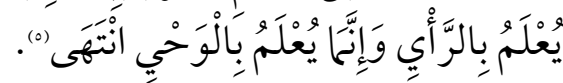

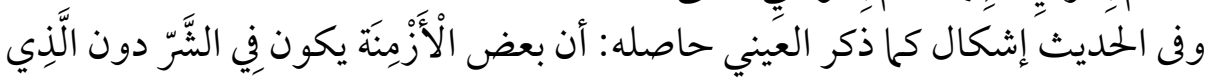
قبله

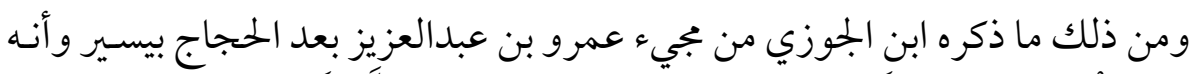

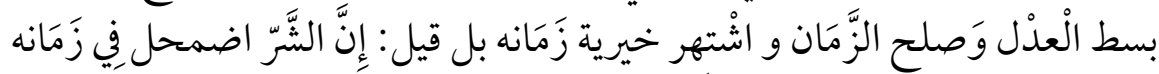

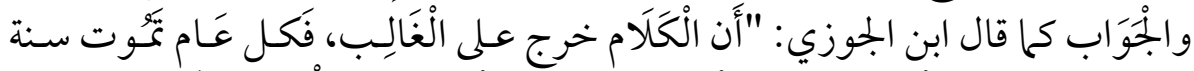

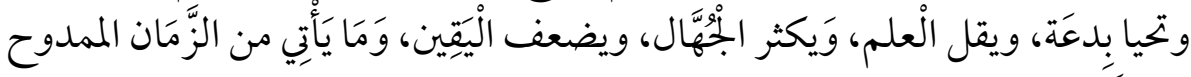

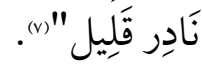

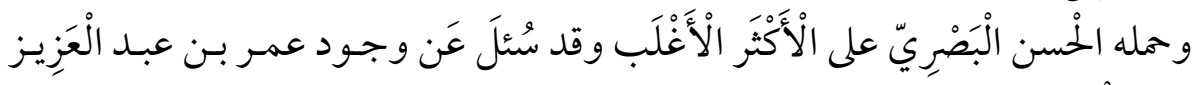

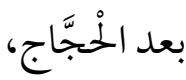

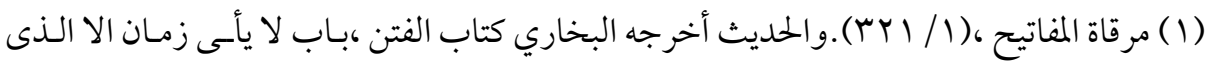

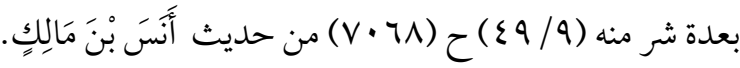

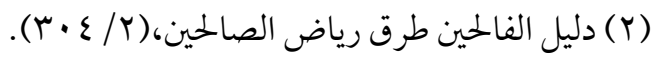

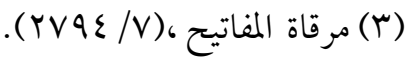

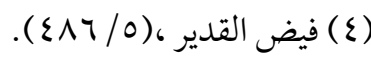

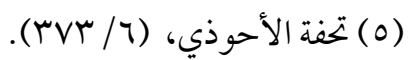




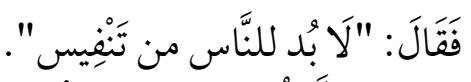

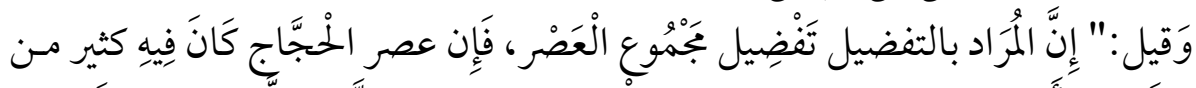

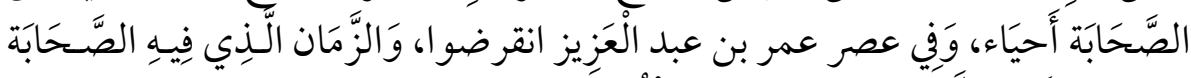

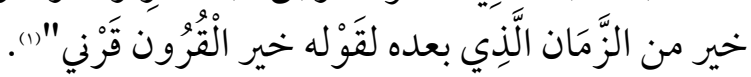

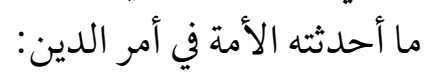

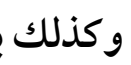

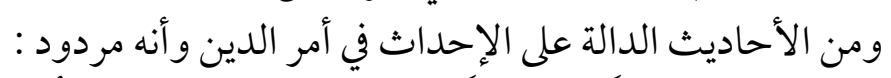

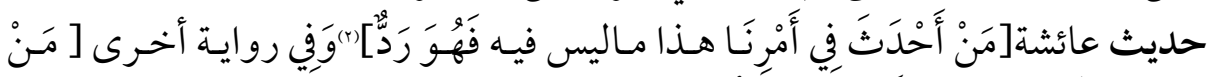

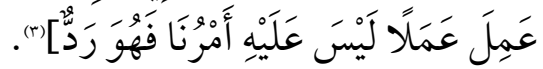

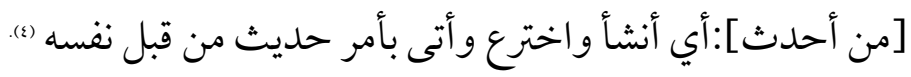

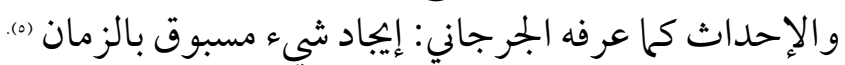

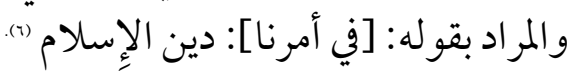

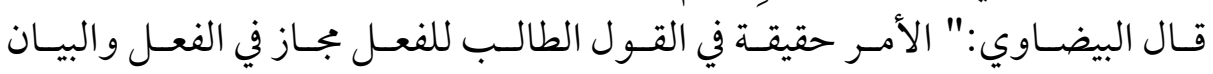

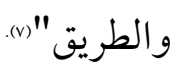

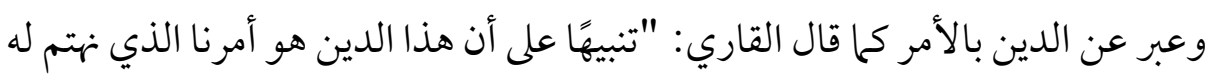

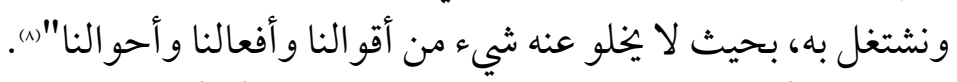

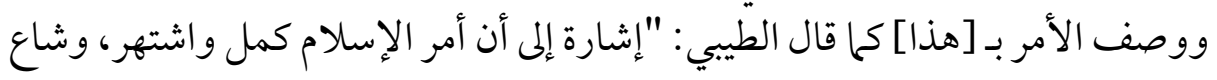

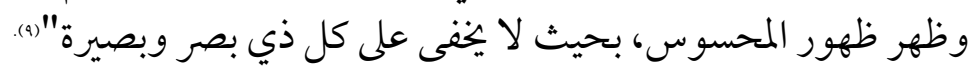

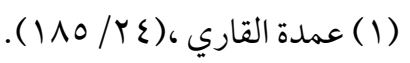

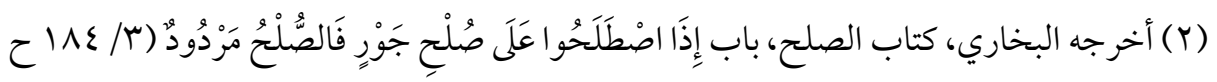

$$
\text { . (r T }
$$

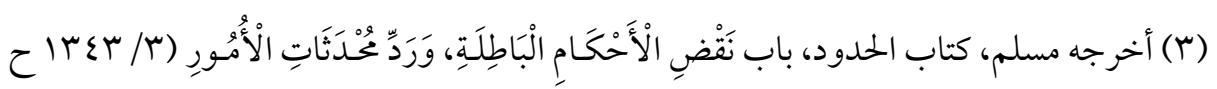

$(1 \mathrm{~V}) 1$

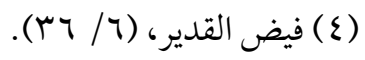

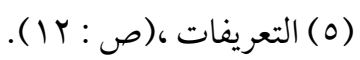

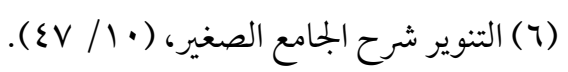

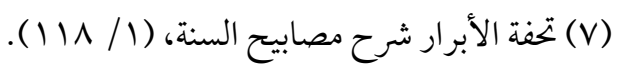

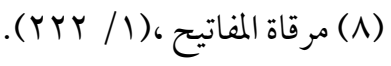

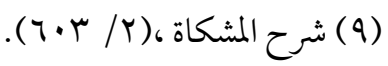




$$
\begin{aligned}
& \text { [ما ليس فيه] أي: ما لم يكن في كتاب ولا سنة ولا قياس صحيح ولا إجماع (1). }
\end{aligned}
$$

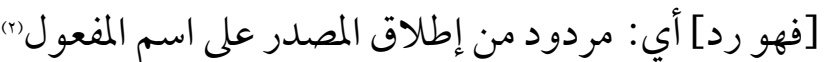

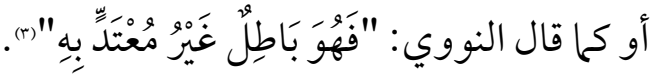

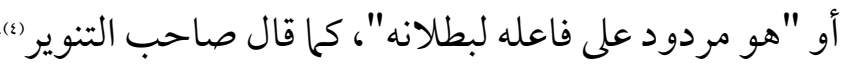

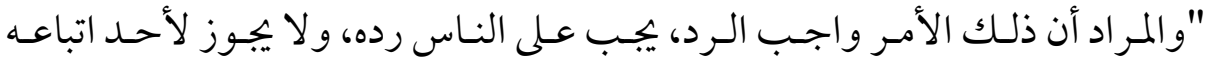

$$
\text { و التقليد فيه" ومادمان. }
$$

وقال البيضاوي:"من أحدث في الإسلام ما لم يكن له من الكتاب أو السنة سـند ظـاهر

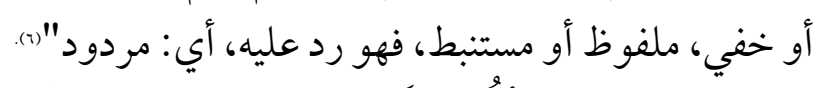

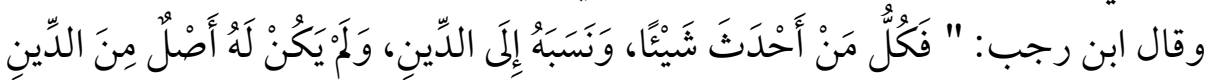

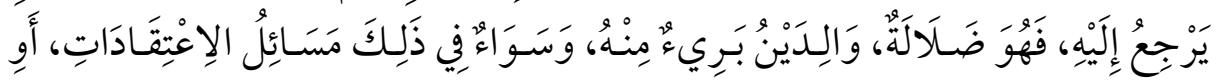

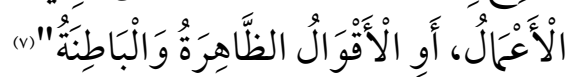

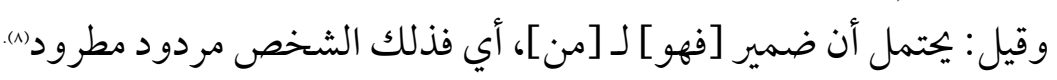

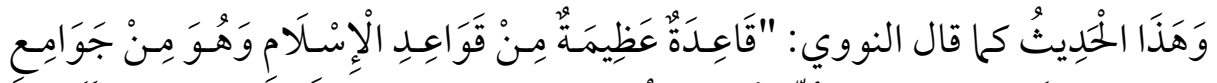

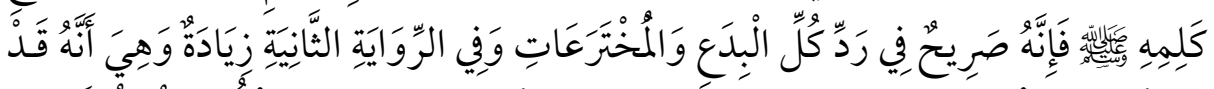

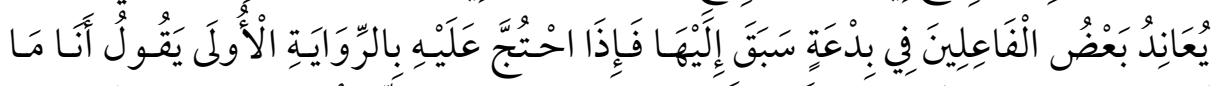

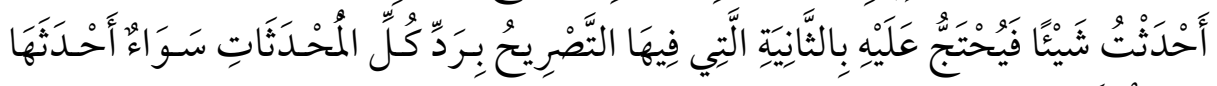

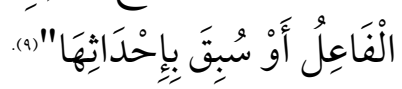

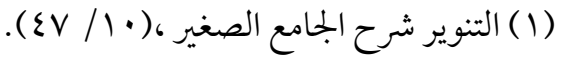

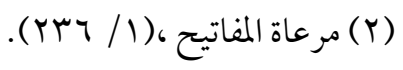

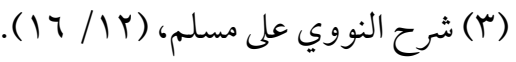

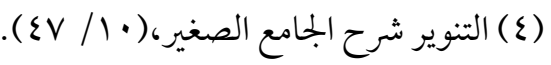

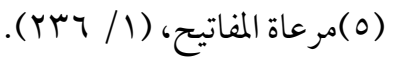

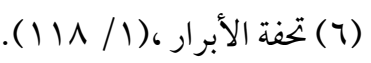

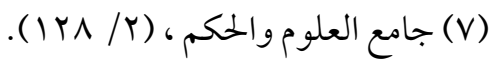

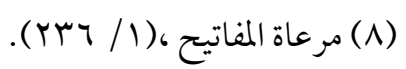

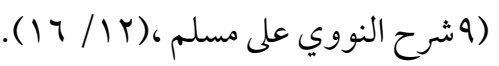




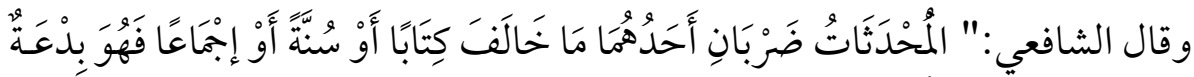

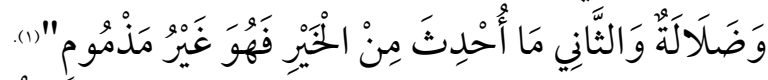

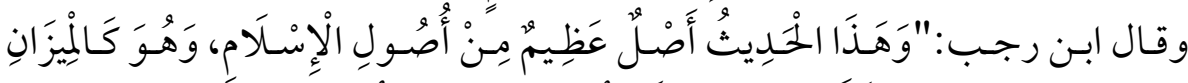

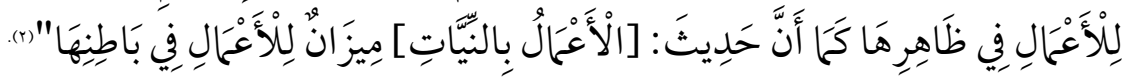

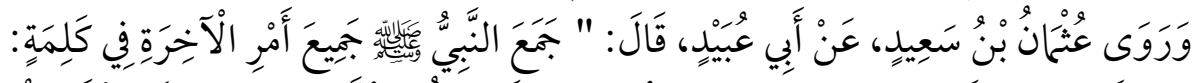

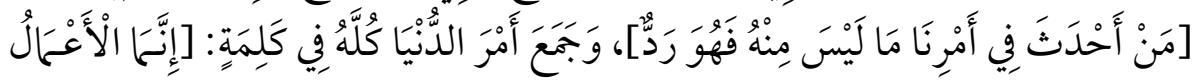
بِالنيَّّاتِ]

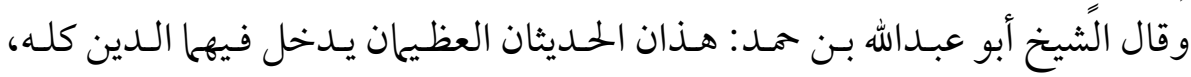

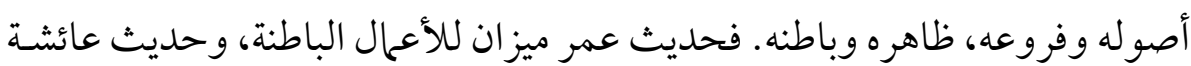

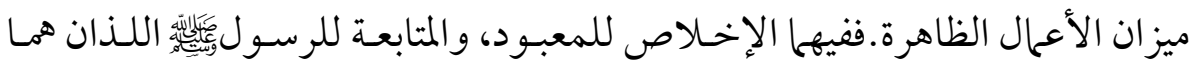

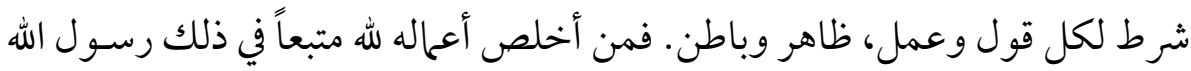

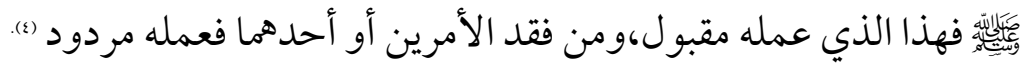

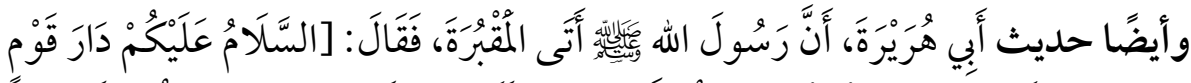

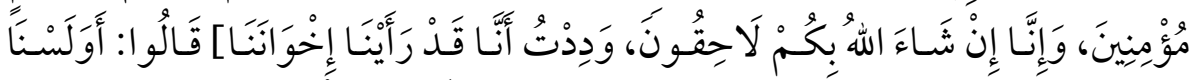

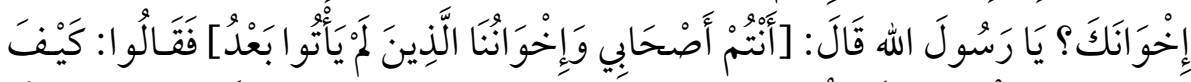

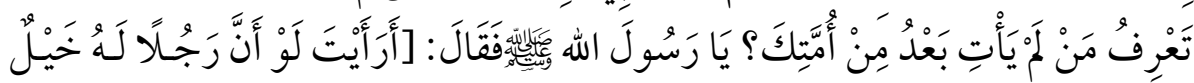

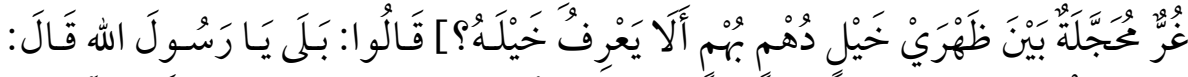

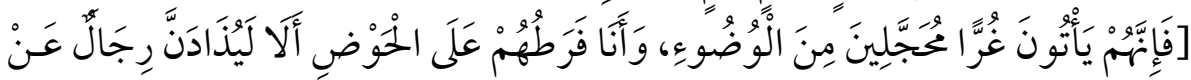

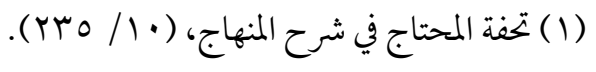

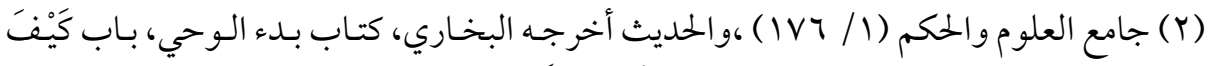

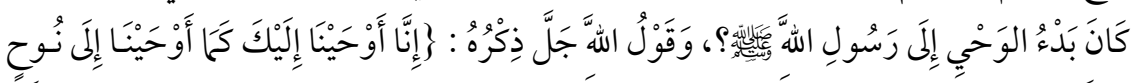

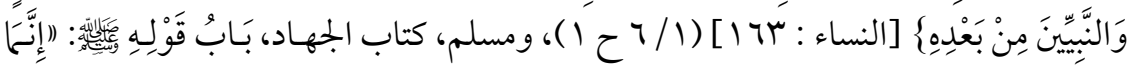

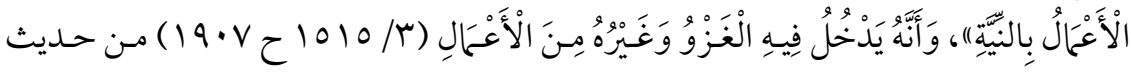

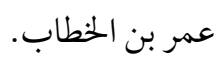

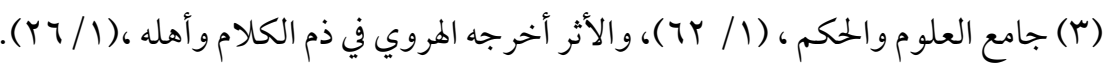

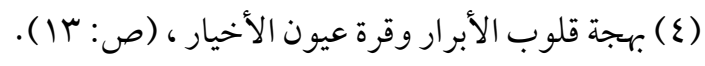




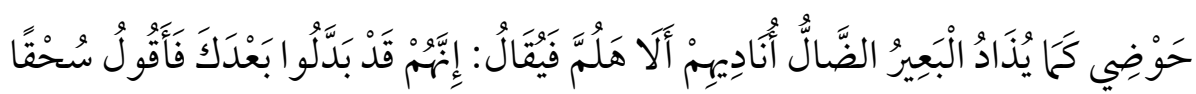

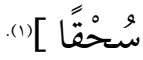

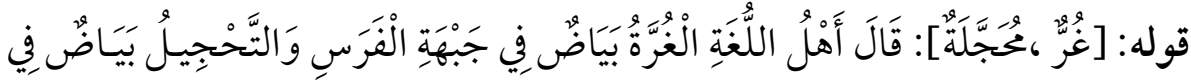

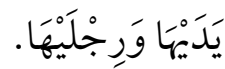

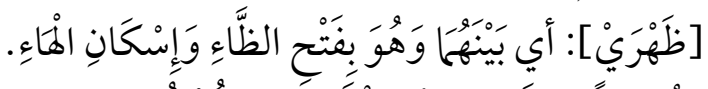

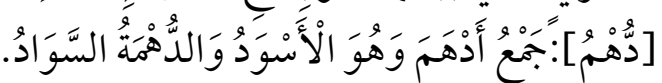

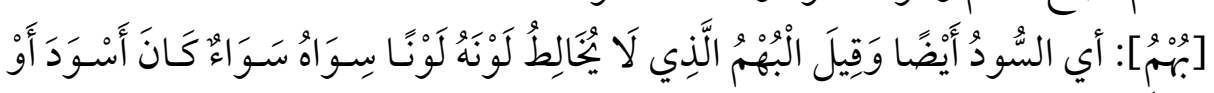

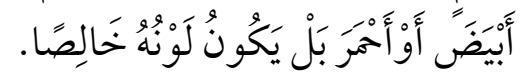

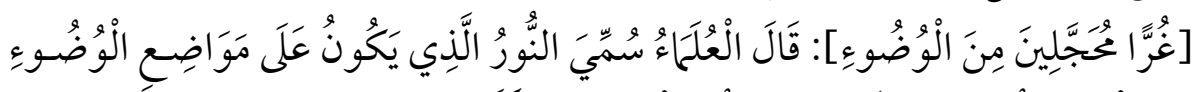

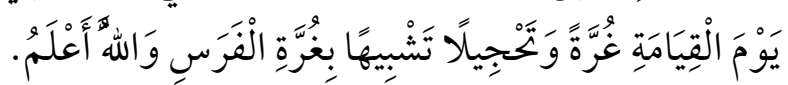

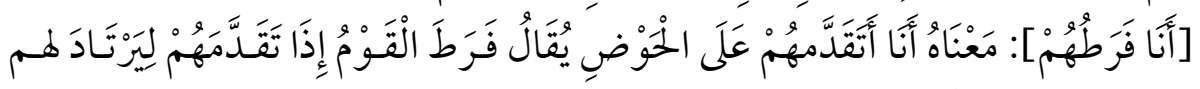

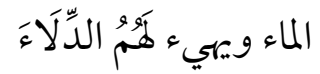

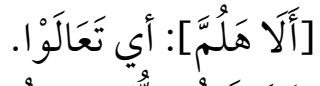

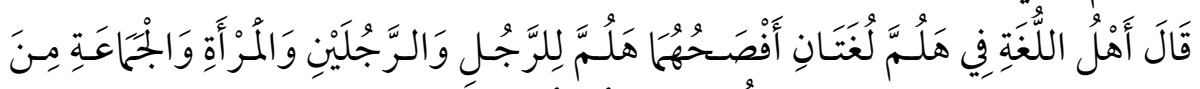

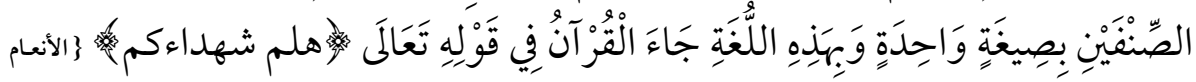

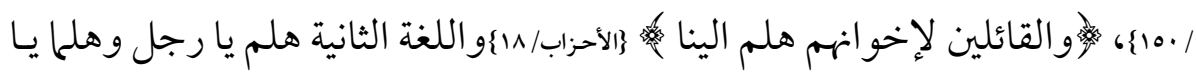

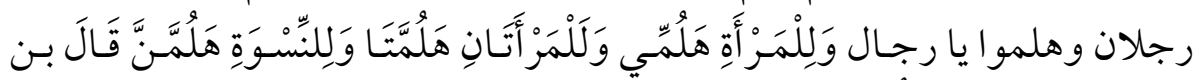

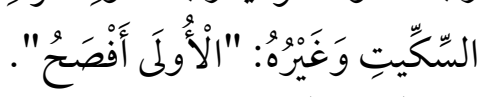

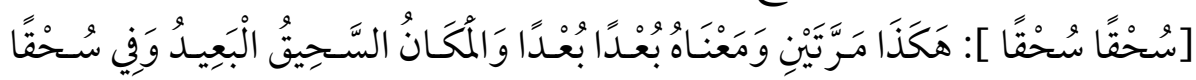

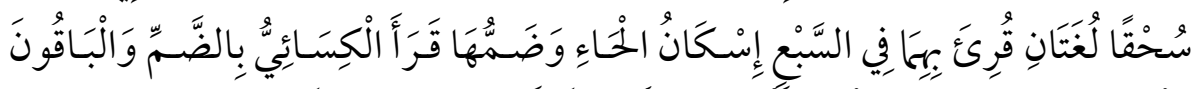

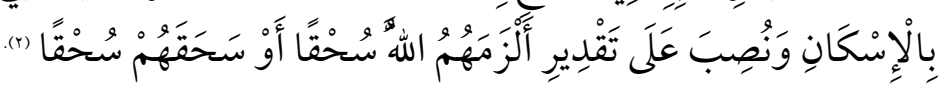

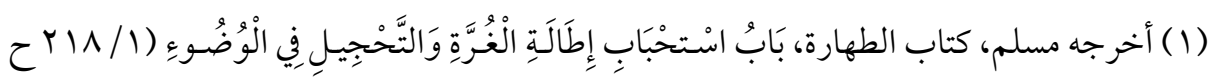
. ( $Y \varepsilon$.

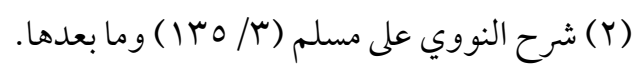
011 


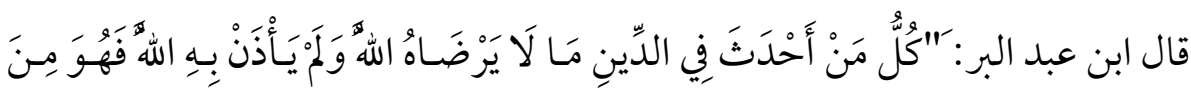

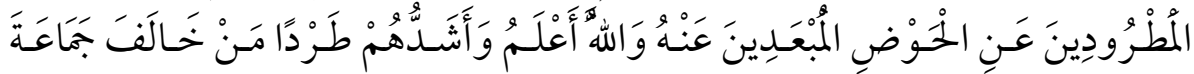

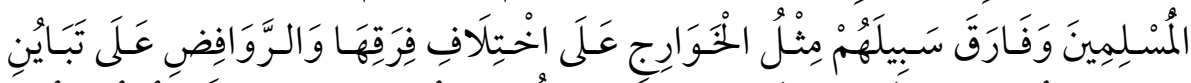

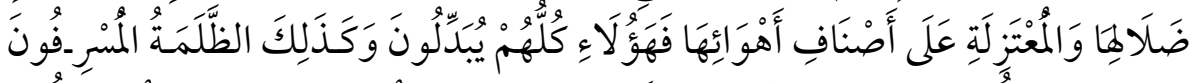

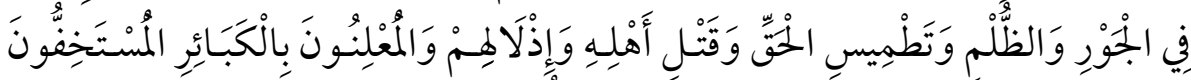

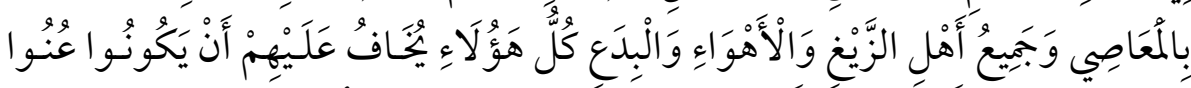

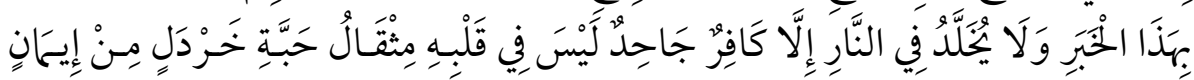

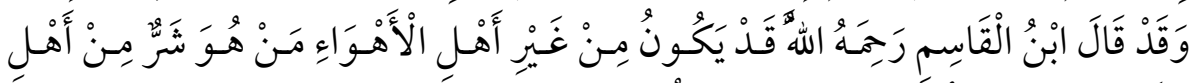

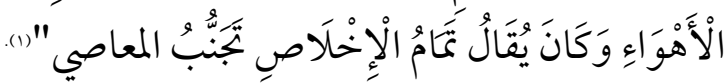

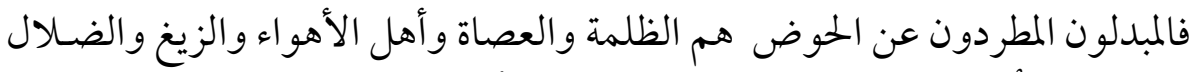

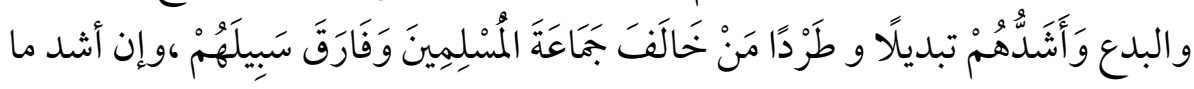

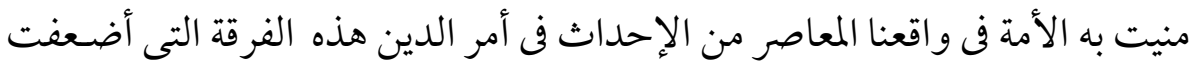

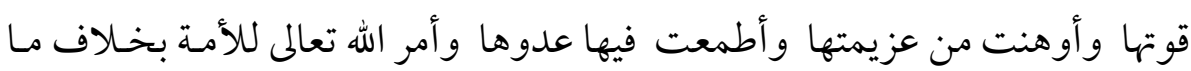

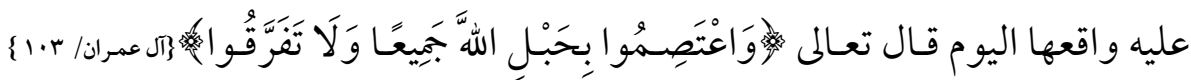

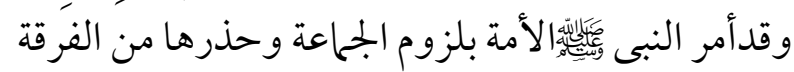

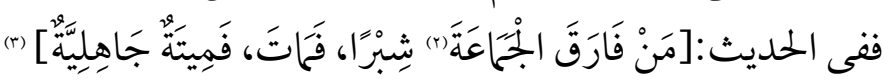

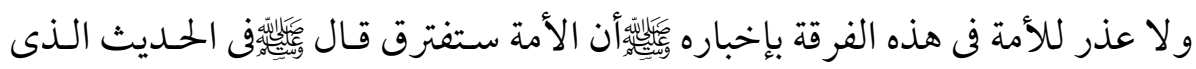

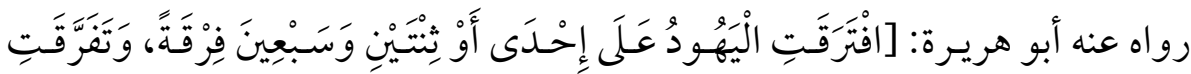

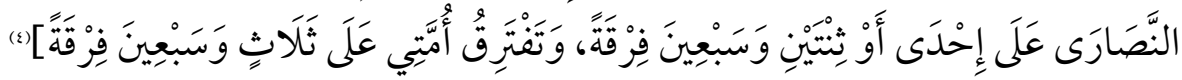

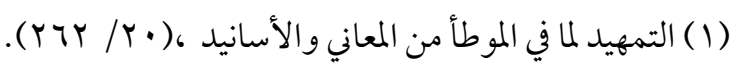

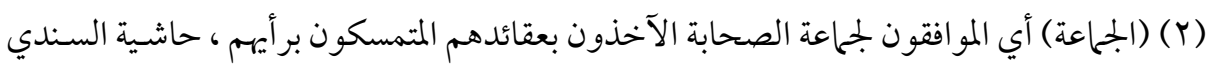

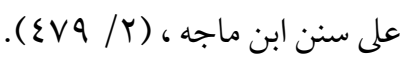

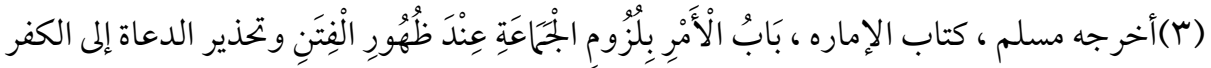

$$
\text { ( ) من حديث ابْنِ عَبَّاسِ. }
$$

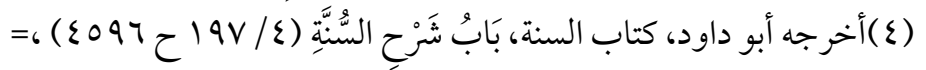




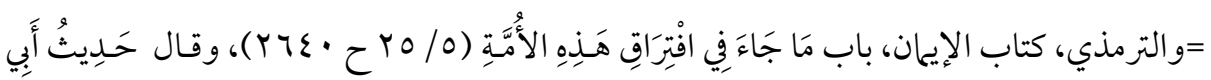

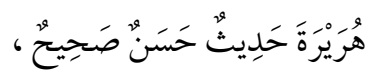

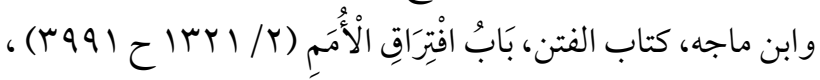

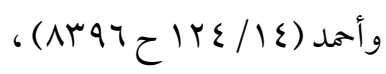

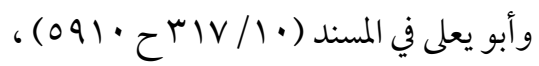

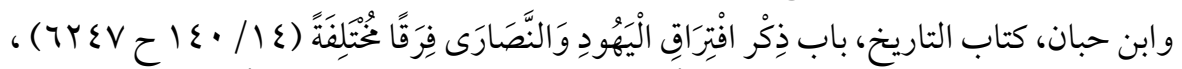

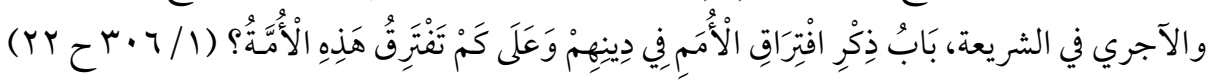

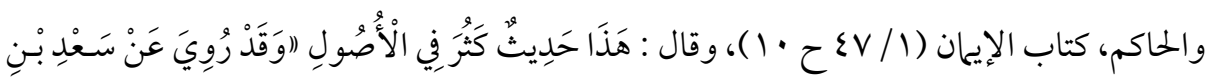

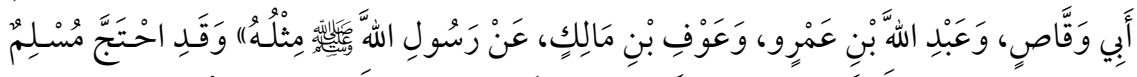

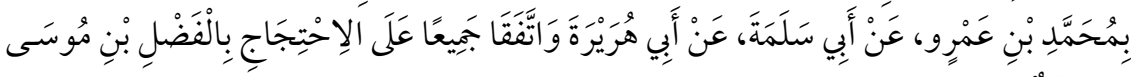

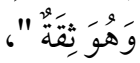
قال الذهبي متعقباً : ما احتج مسلم بمحمد بن عمرو منفردا بل بانضمامه إلى غيره ، ثم أخر جه الحاكم

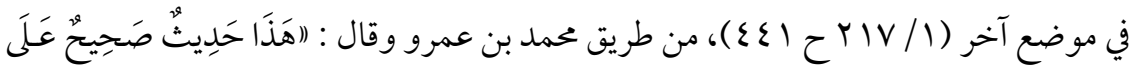

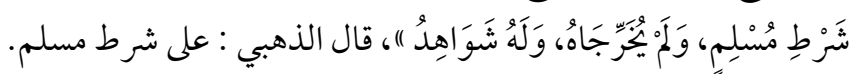

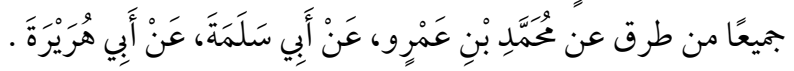

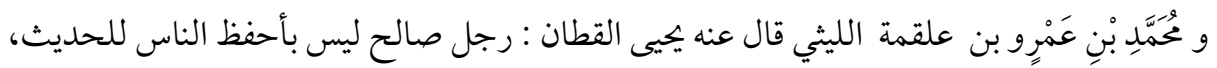

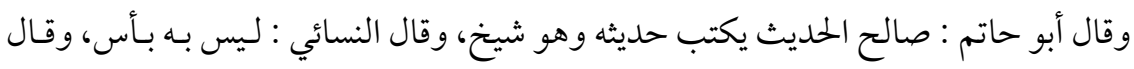

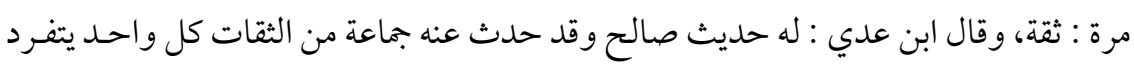

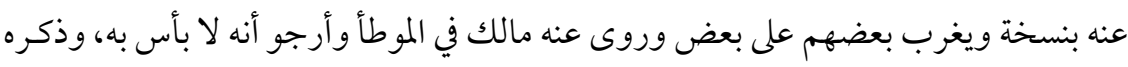

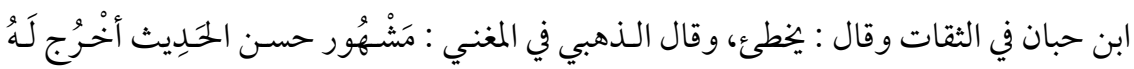

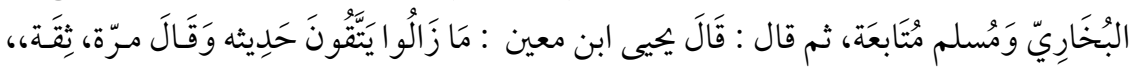

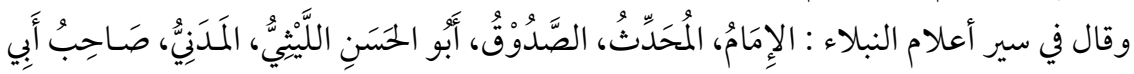

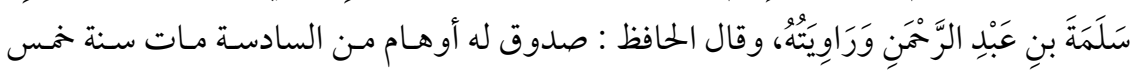

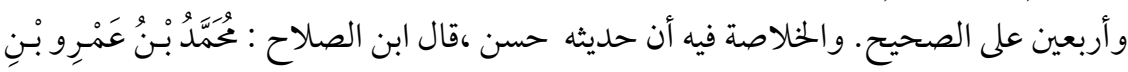

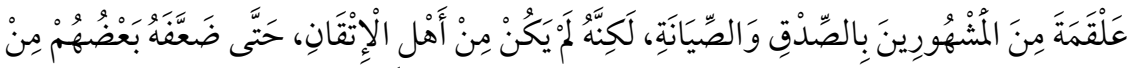

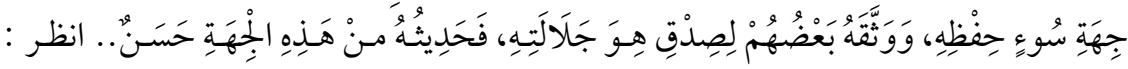

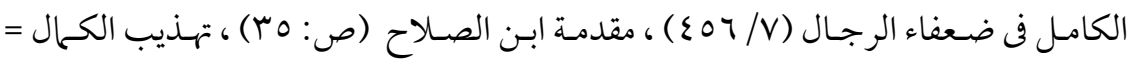


تق

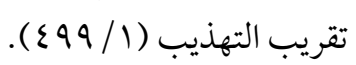

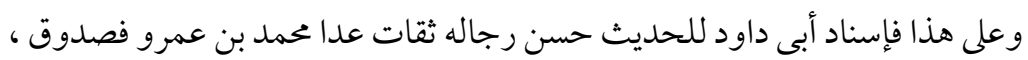

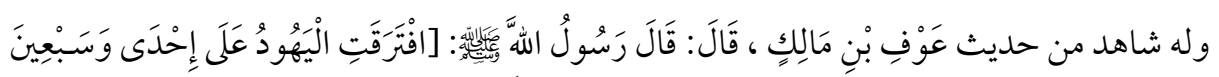

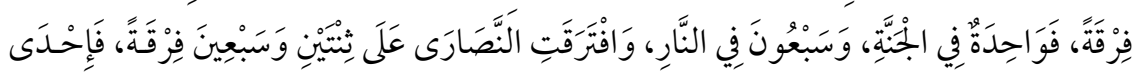

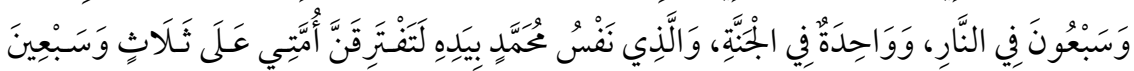

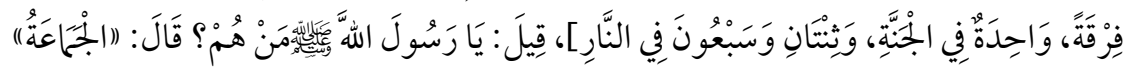

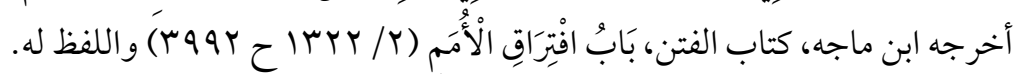

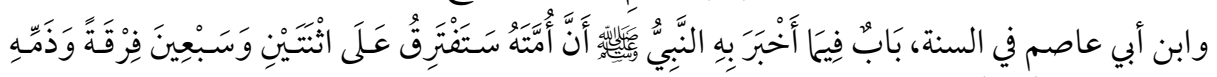

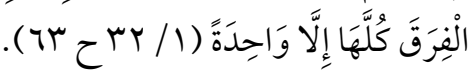

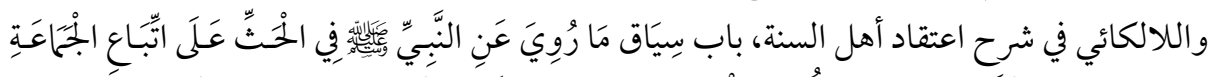

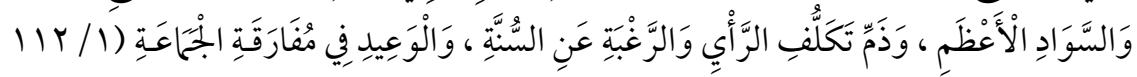

$$
\text { ( } 1 \leqslant 9 \text { ح }
$$

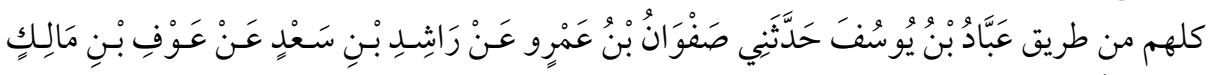
الأشَْجَعِيِ.

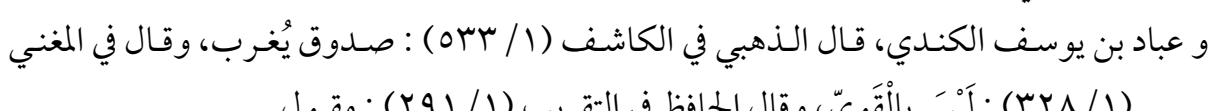

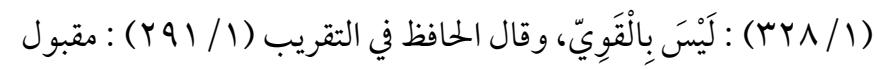

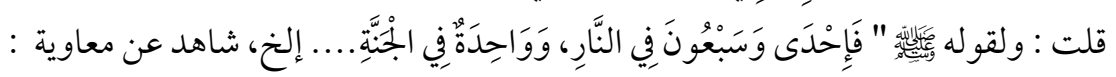

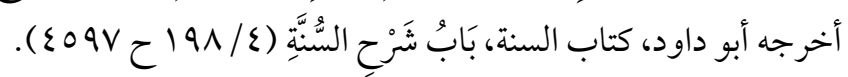

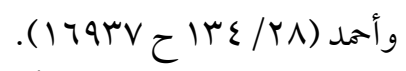

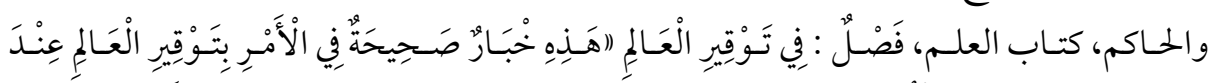

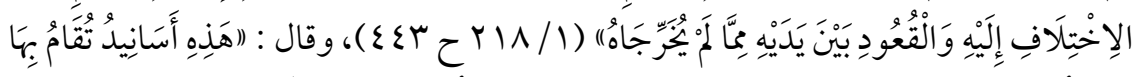

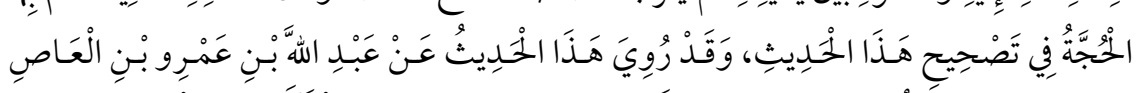

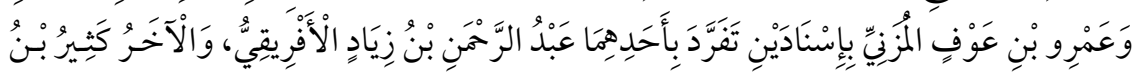

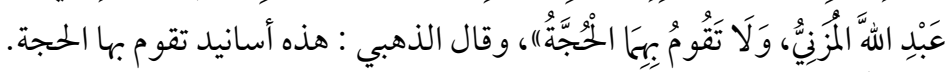

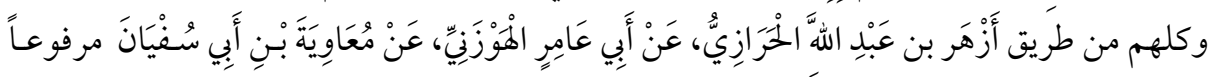




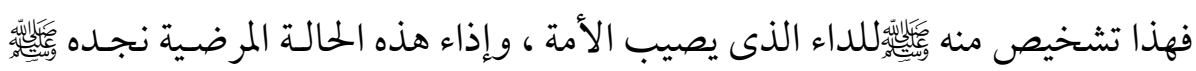

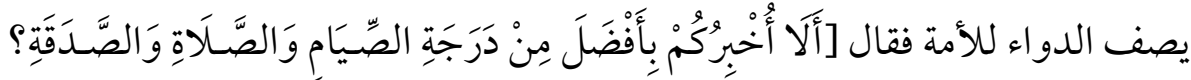

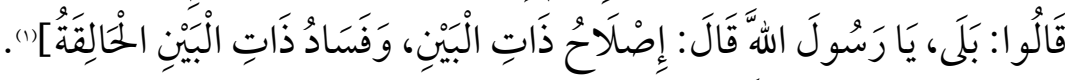

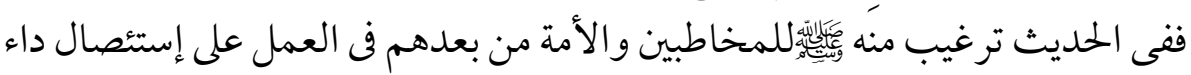
الفرقة من جسد الأمة وتوحيد صفها وجمع كلمتها و إصلاح ذات ذات بينها.

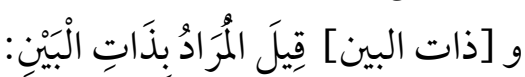

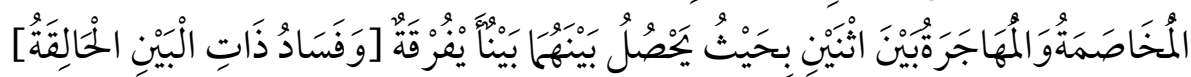

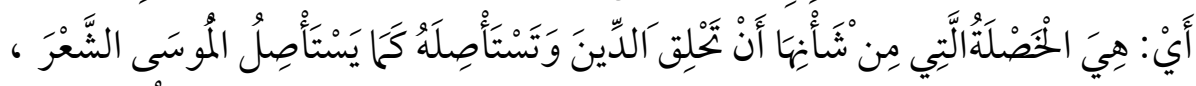

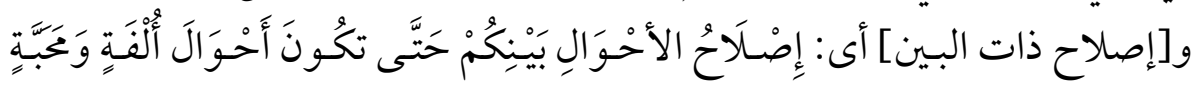

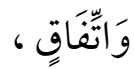

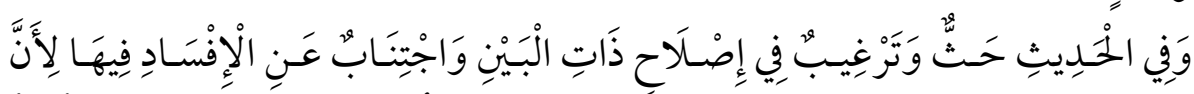

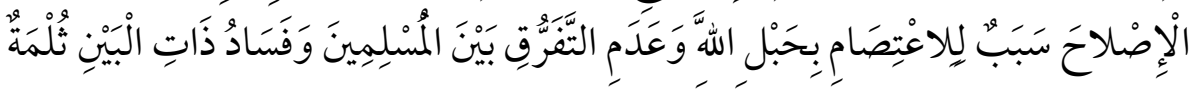

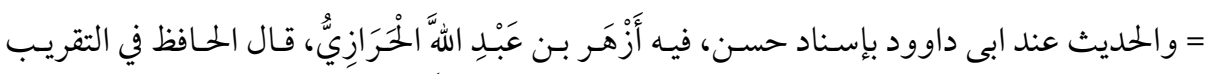
(91/1) ) : صدوق تكلموا فيه للنصب.

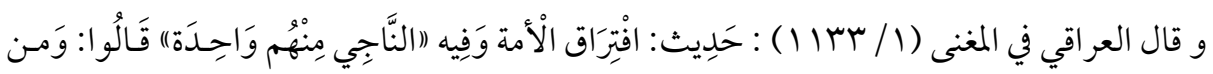

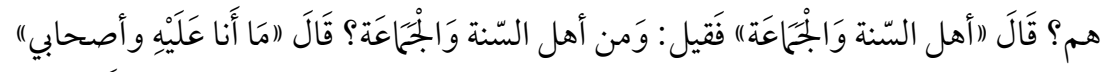

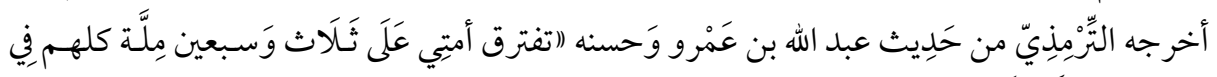

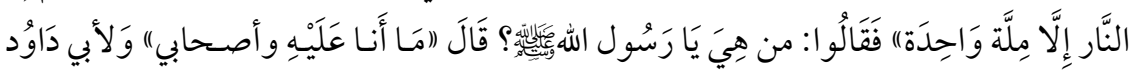

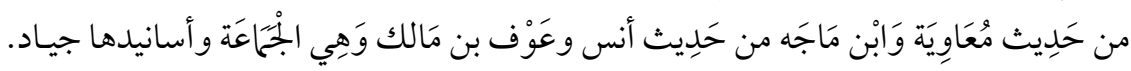

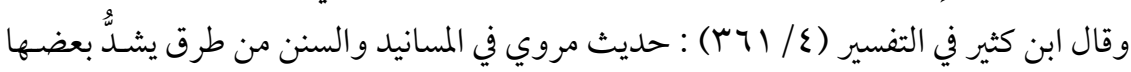

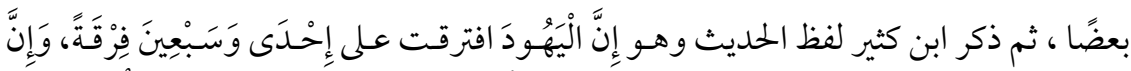

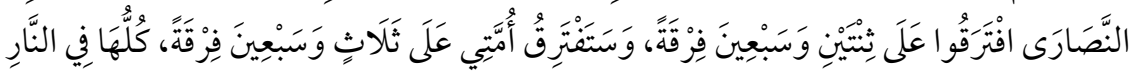

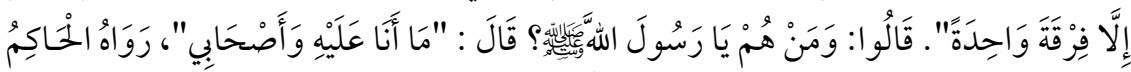

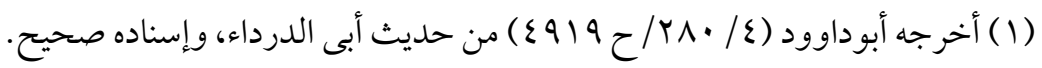




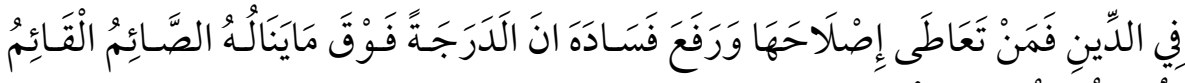

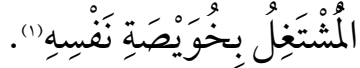

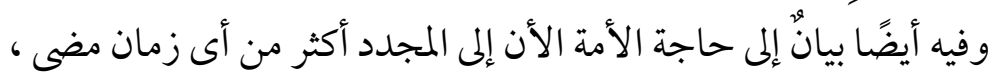

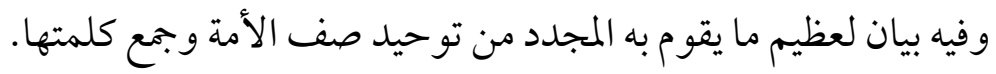




\section{المبحث الرابع \\ المرادمن قوله:[على رأس كل مائة سنة]}

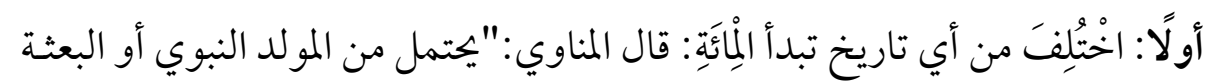

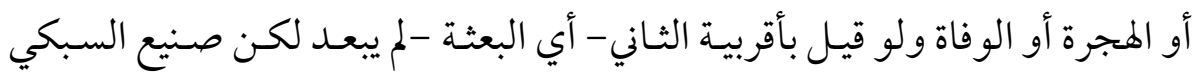

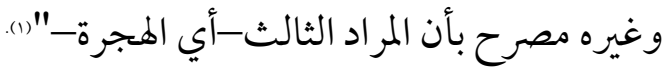

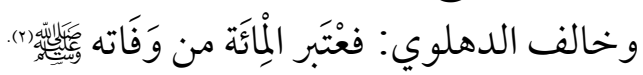
والأول المشهور وعليه عمل الأمة في التأريخ بالهجرة.

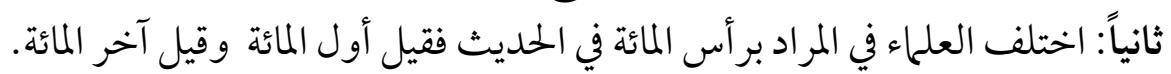

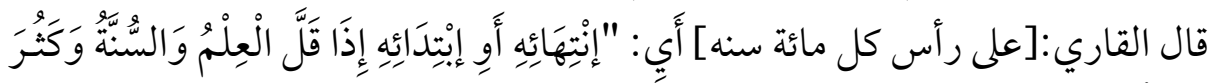

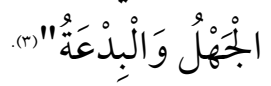
ومنشأ هذا الاختلاف هو أن الرأس يطلق في اللغة ويراد به أول الشيء كما يراد به آخر

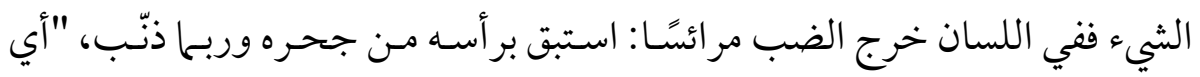

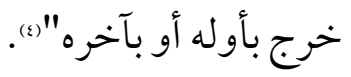

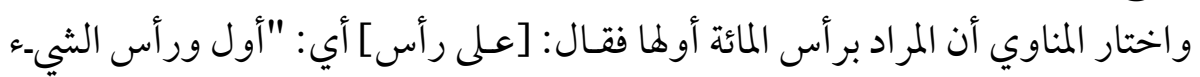

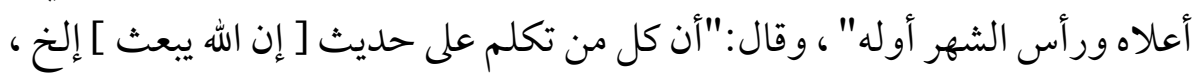

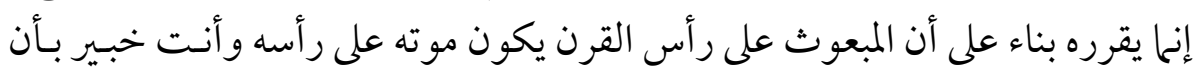

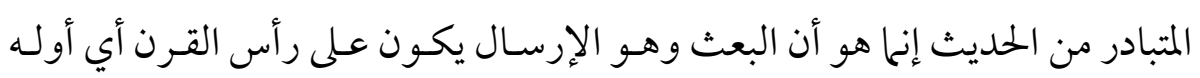

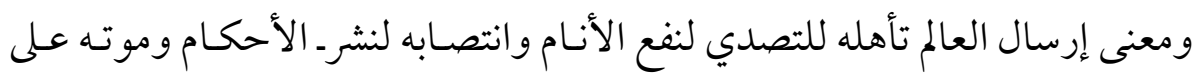

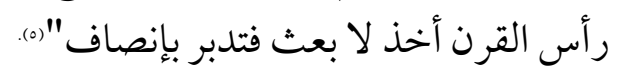

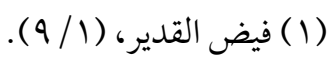

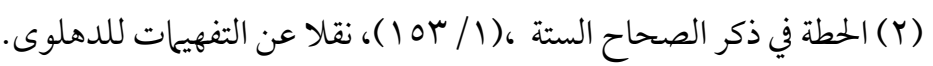

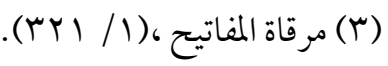

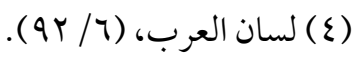

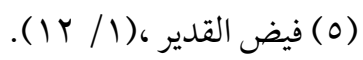




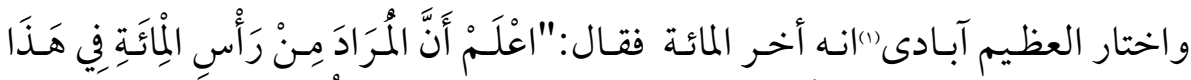

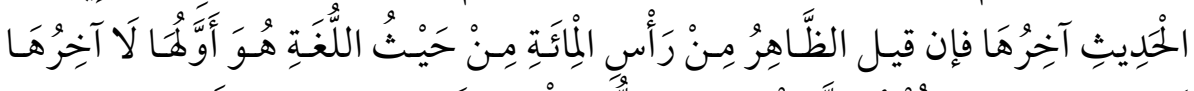

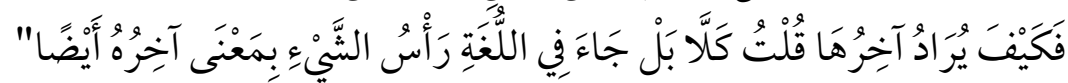

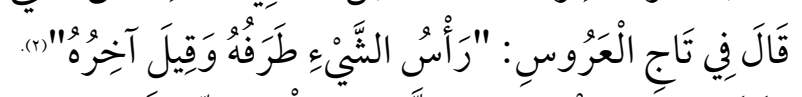

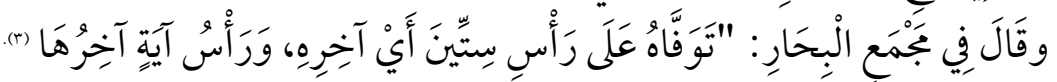

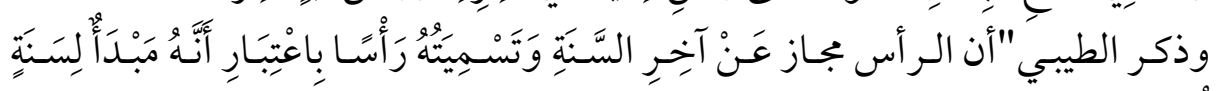

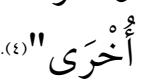

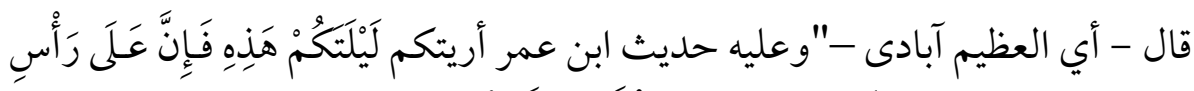

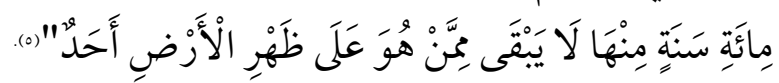

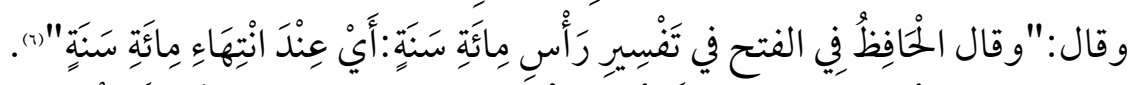

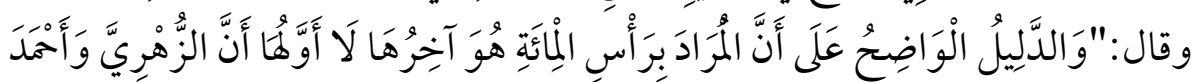

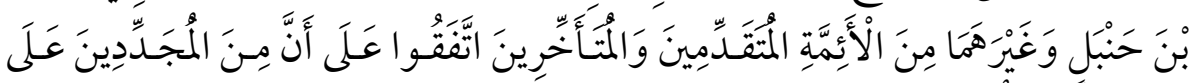

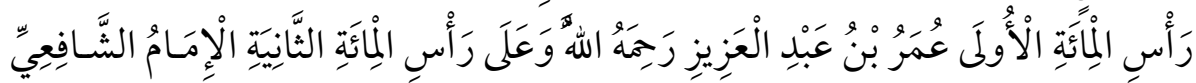

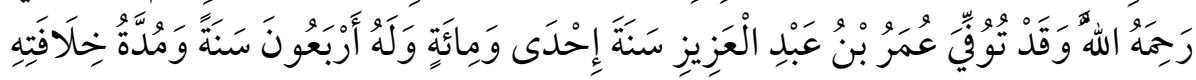

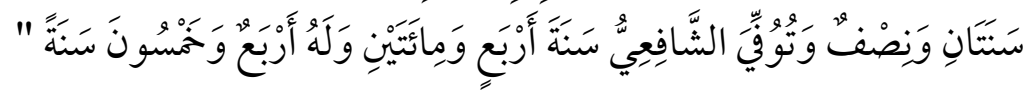

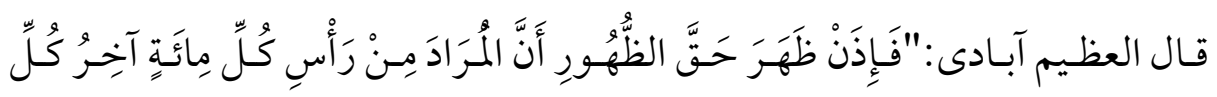

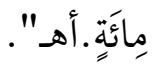

( ) ) (عون المعبود د) (Y) (Y) (Y) ومابعدها.

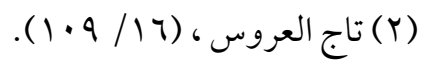

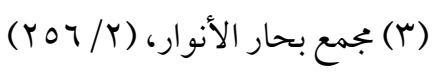

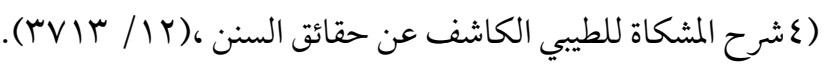

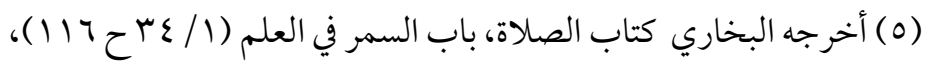

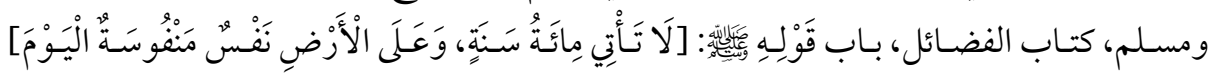

(rorv ح 1970/乏)

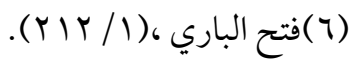

011 


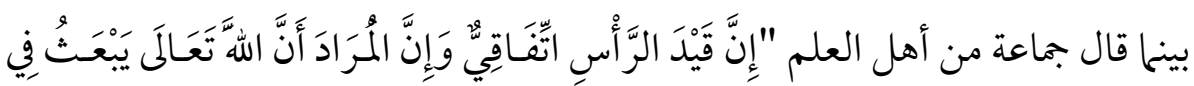

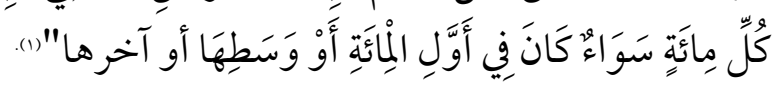

\section{الترجيح:}

القول بأن رأس المائة: آخرها هو أرجح هذه الأقوال وبه قال جمع من العلماء.

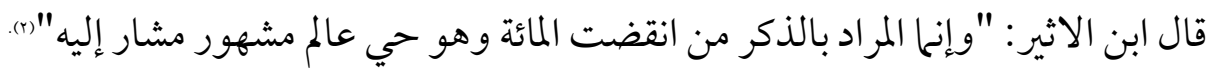

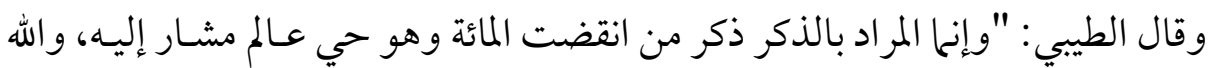

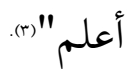
وقال الكرماني: "وقد كان قبل كل مائة أيضاً من يصحح ويقوم بأمر الدين وإنها المراد من انقضت المائة وهو حي عالم مشار إليه" (8)، وقان

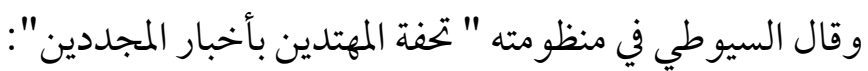

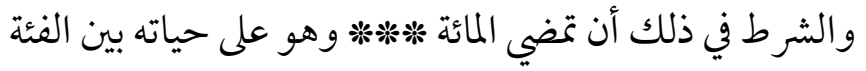

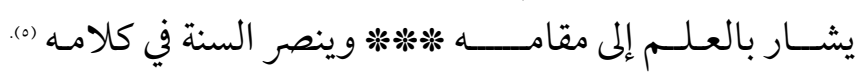

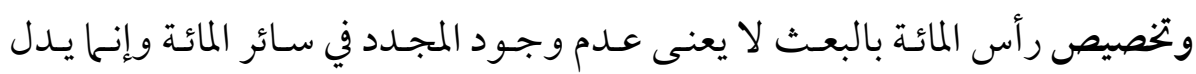

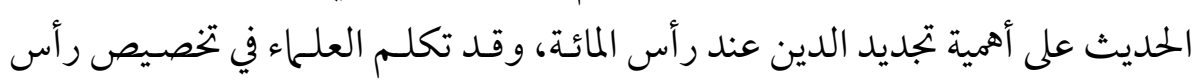
المائة بالبعث والتجديد.

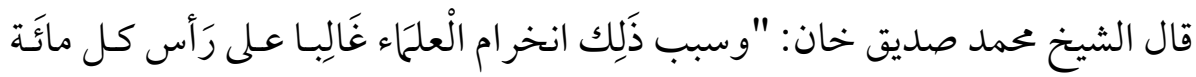

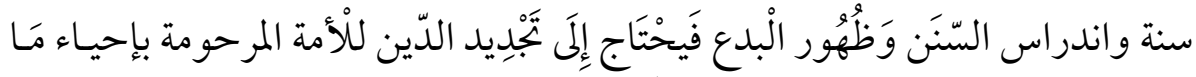

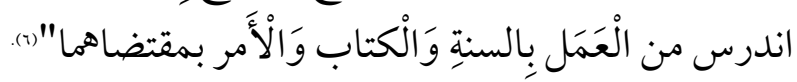

$$
\begin{aligned}
& \text { (1) عون المعبود، (11/Y (Y (Y)). }
\end{aligned}
$$

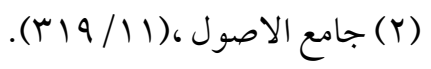

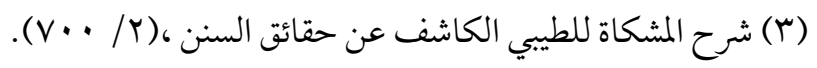

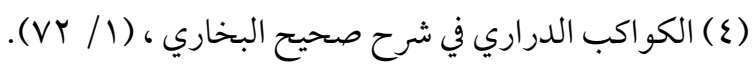

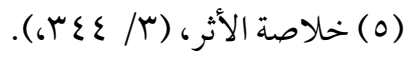

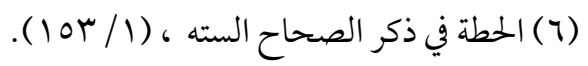




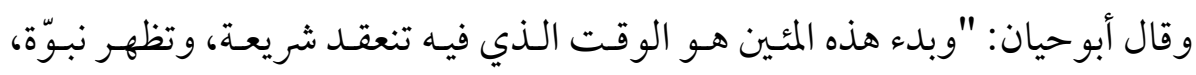

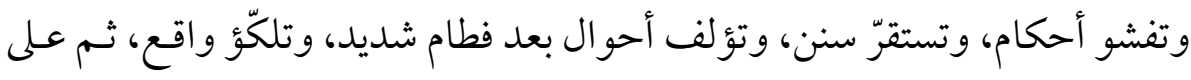

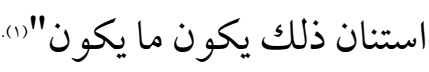

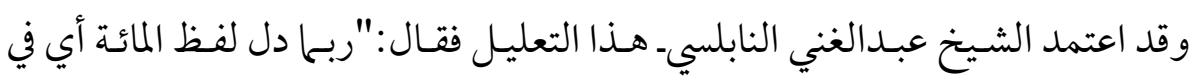

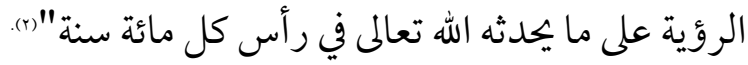
وهذا يظهر أهمية التجديد على رأس المائة مع اتفاق العلماء على أن أن التجديد لائل اينقطع في

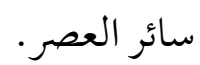

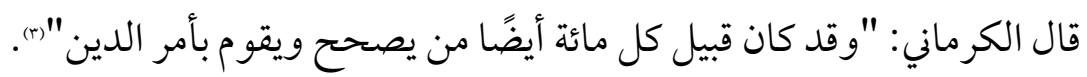

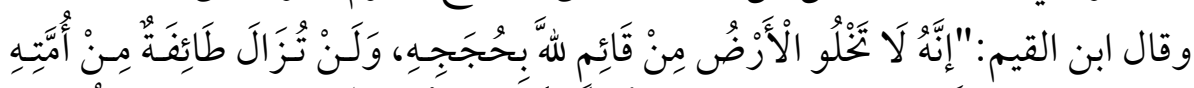

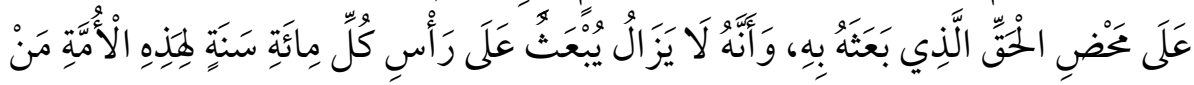

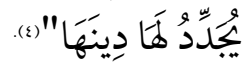

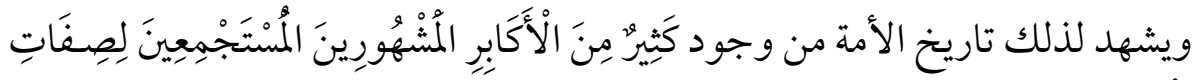
المُجَدِدِيَّة في غير رأس المائة. ومن هؤل ألاء الأكابر:

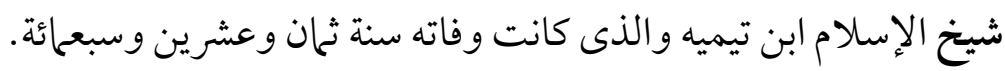

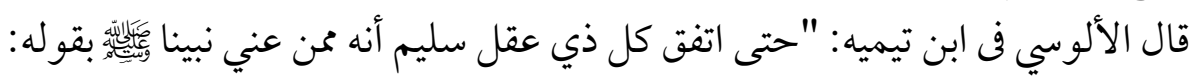

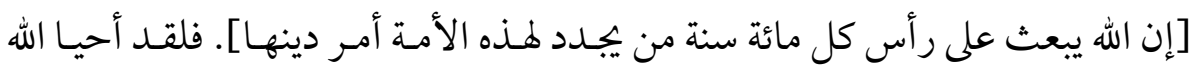

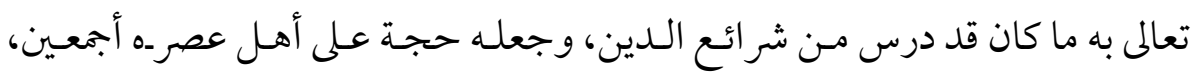

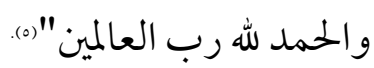

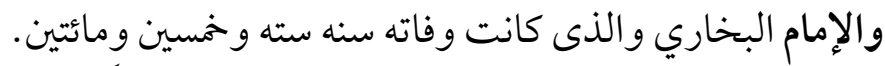

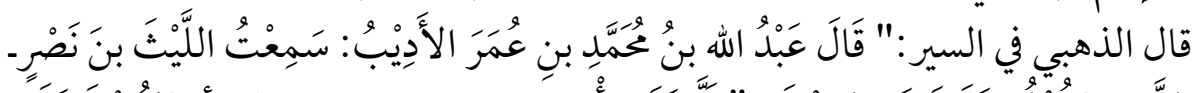

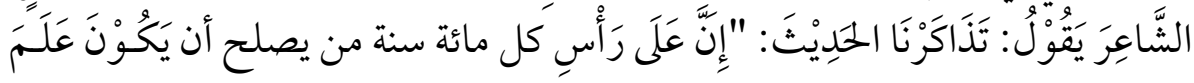

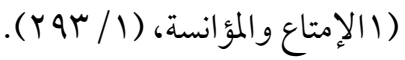

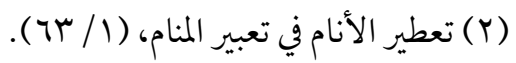

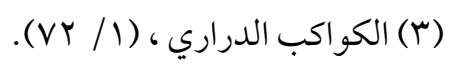

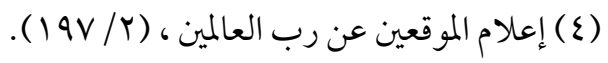

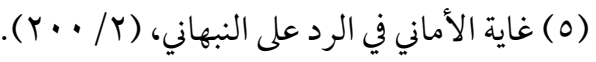




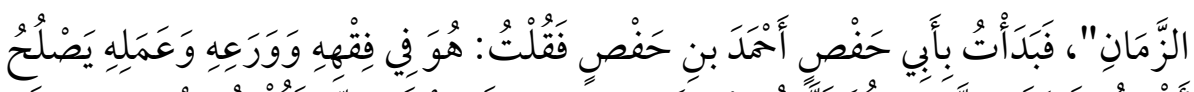

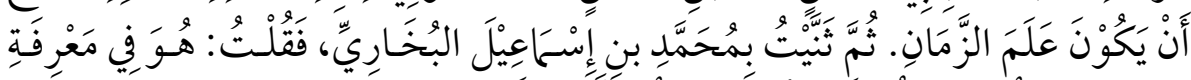

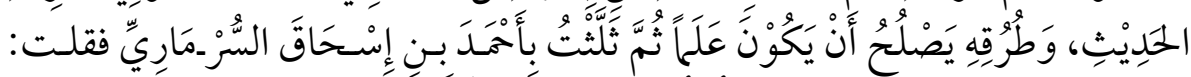

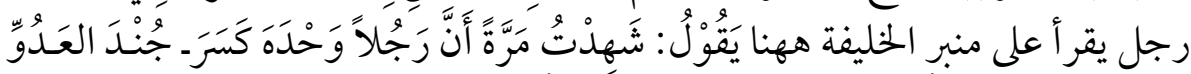

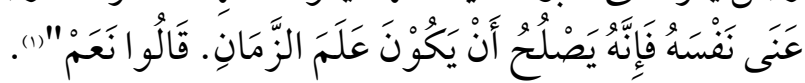

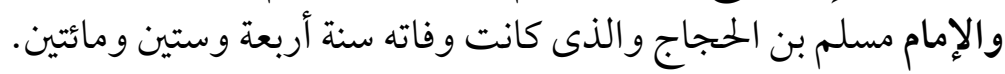

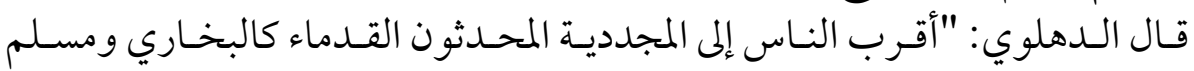

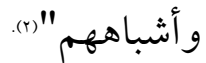
والإمام أحمد بن حنبل والذي كانت وفاته واته سنة إحدى وأربعين ومائتئين.

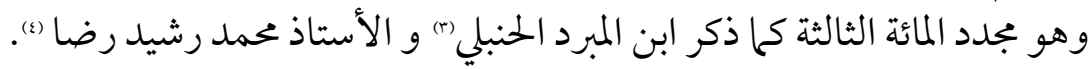

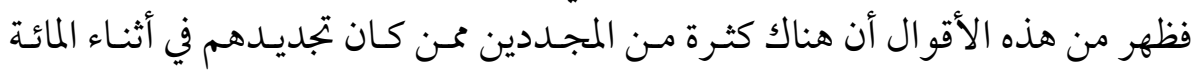

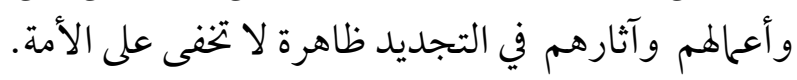

الخلاصة:

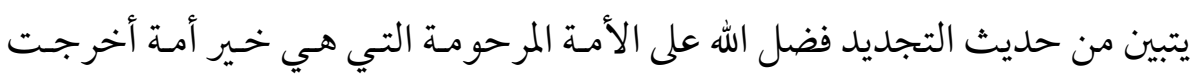

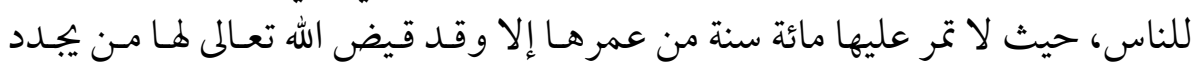

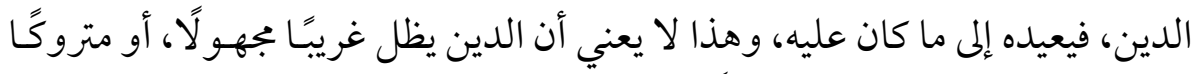

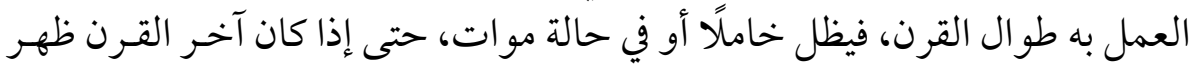

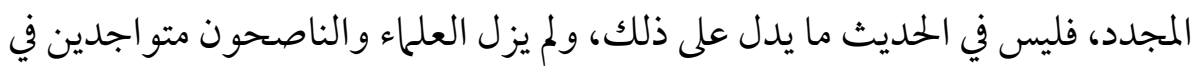

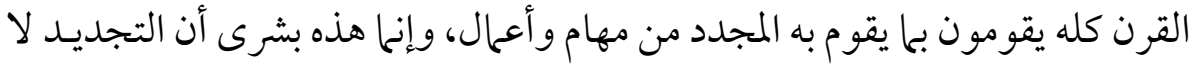

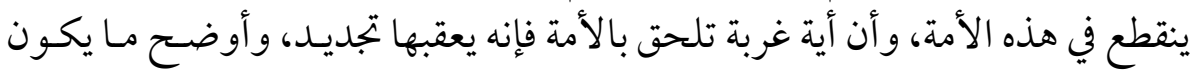

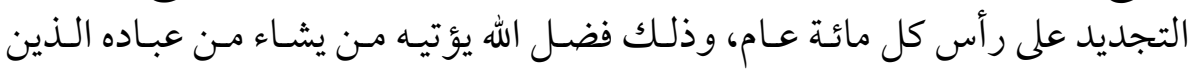

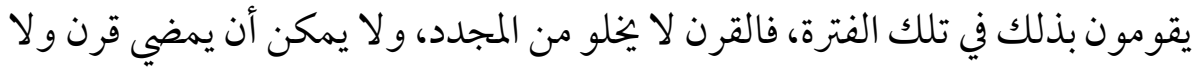
مجلد فيه.

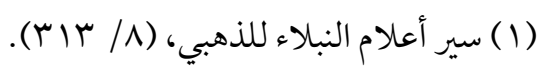

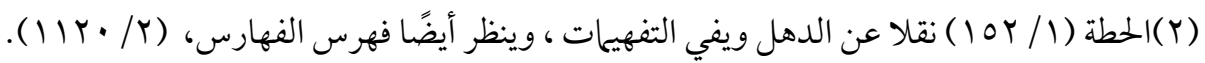

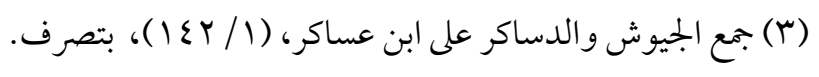

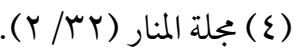




\section{المبحث الخامس \\ بقاء الدين واستمر اره إلى قيام الساعة}

في الحديث دلالة على حفظ الدين وبقائه واستمراره مابقى الزمان بمقتضى ما وعد الله

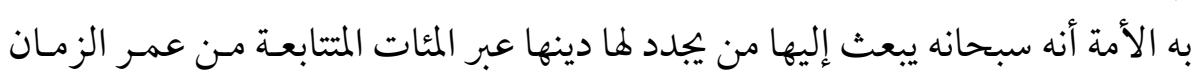

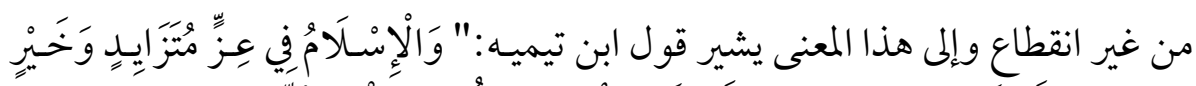

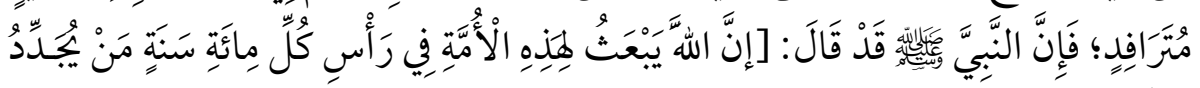

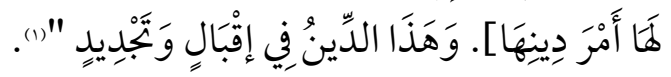

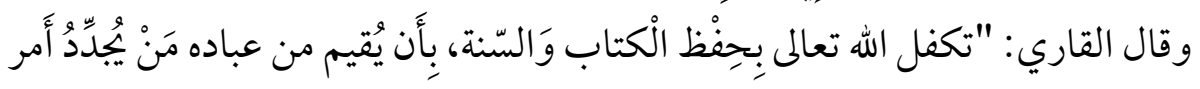

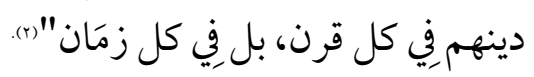

و التعبير بالمضارع في قوله [يبعث ] فيه دلالة على أن هذا البعث لا ينقطع عن في الأمة، وقوله يجدد يفيد حصول التجدد مرة بعد مرة على الدوام من غير انقطاع. ومن الأحاديث الدالة على استمر ار الدين وبقائه إلى قيام الساعة:

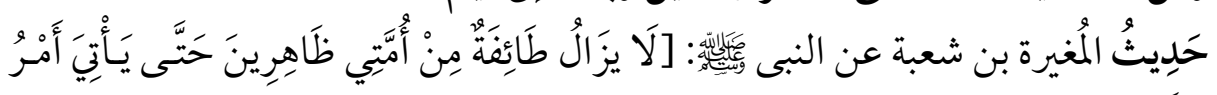

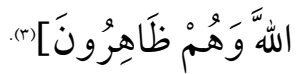

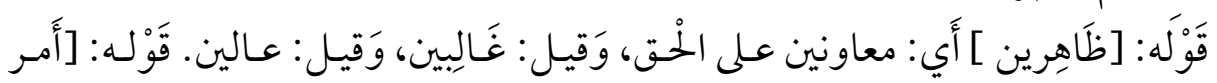
الهَأَي: الْقِيَّامَة.

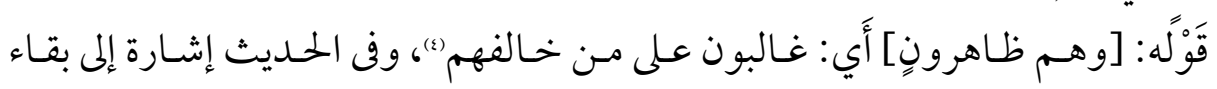
الدين ببقاء هذه الطائفة ظاهرين على الحت وهى بـ باقية بإذن الله إلى أن يأتي أمـر الله فليزم من بقائها بقاء الدين.

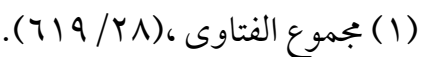

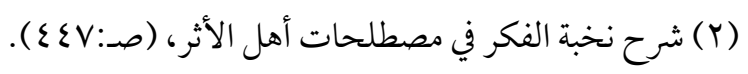

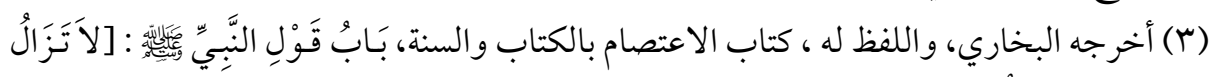

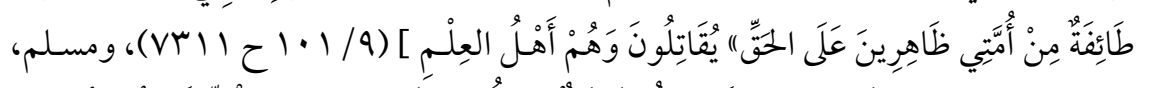

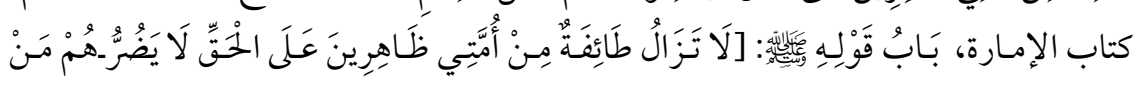

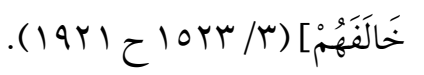

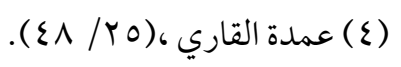




$$
\text { وقد تواردت أقوال العلماء تؤكد ذلك. }
$$

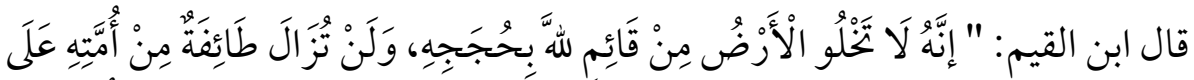

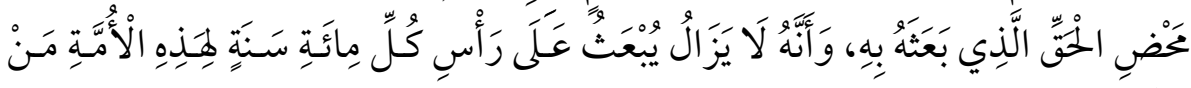

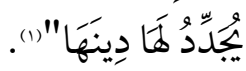

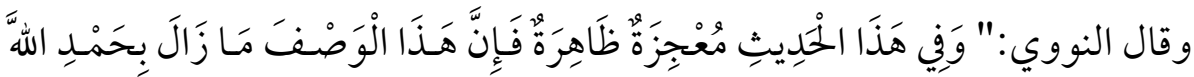

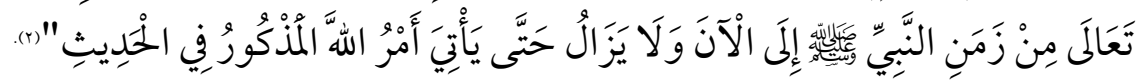

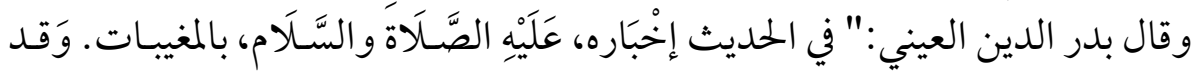

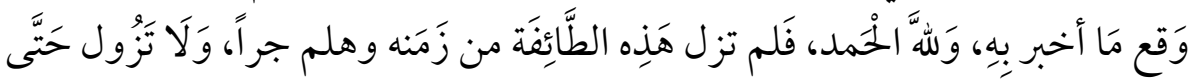

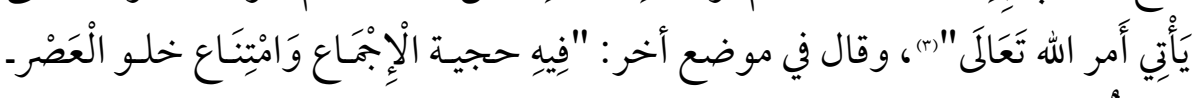

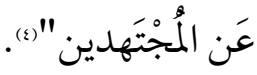

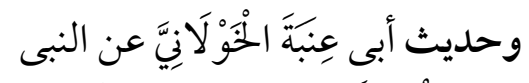

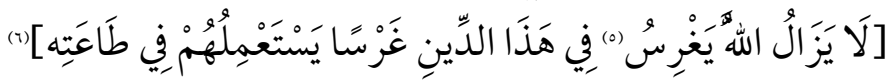

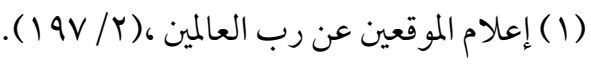

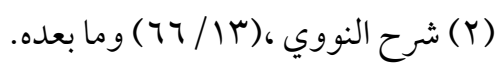

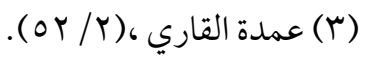

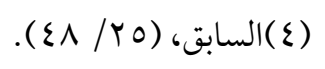

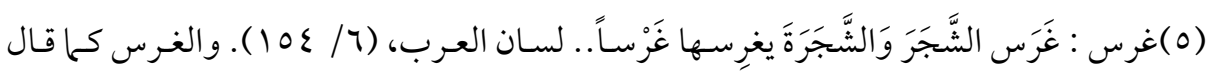

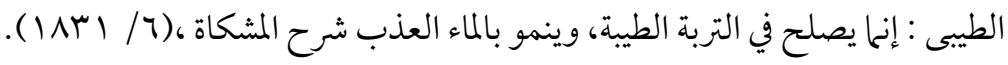

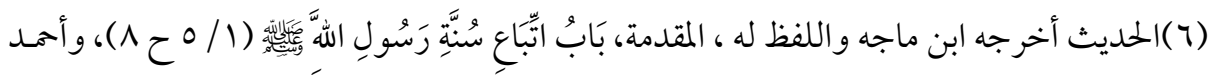

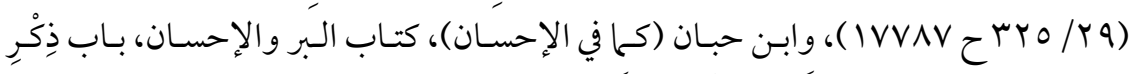

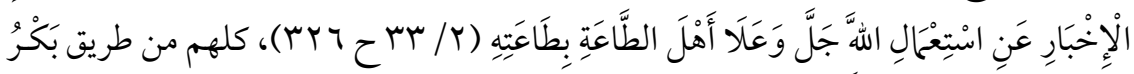

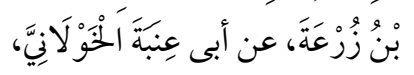

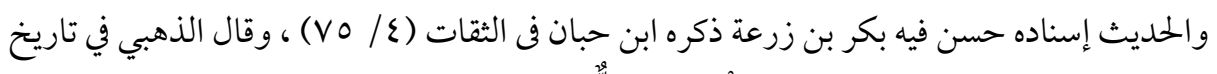

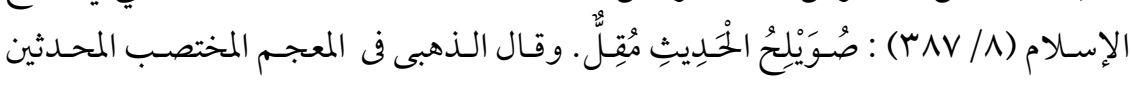

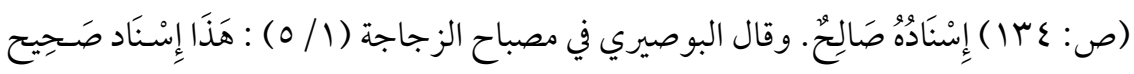

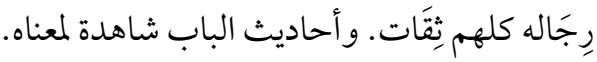




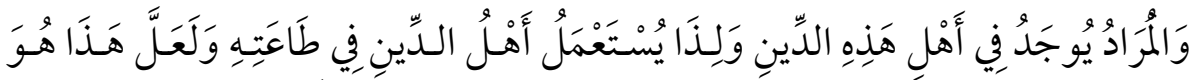

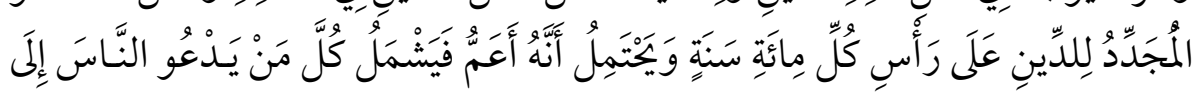

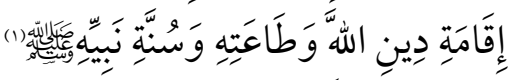

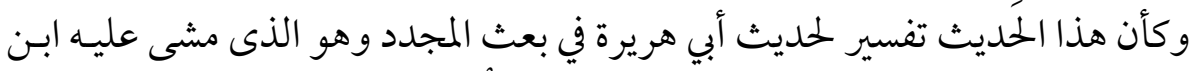

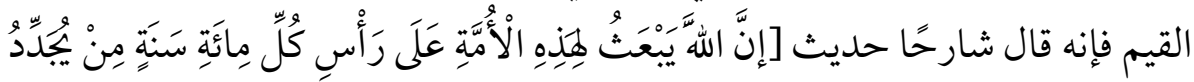

هَّا دِينَهَا.].

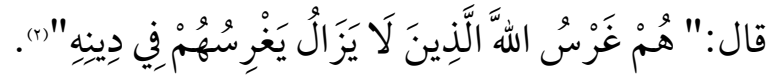

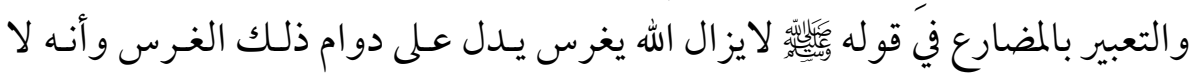
ينقطع عن الأمة أبداً.

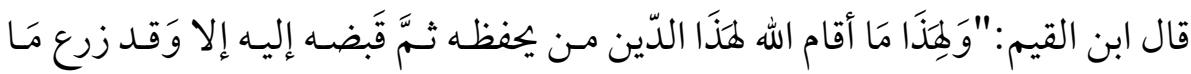

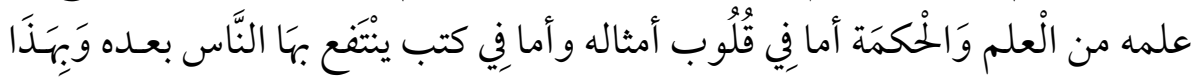

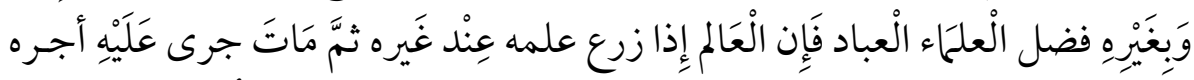

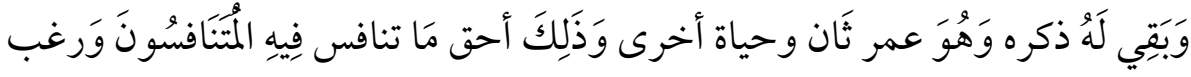

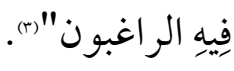

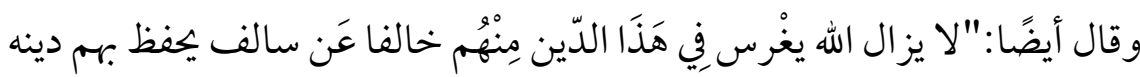

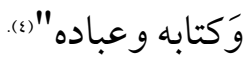

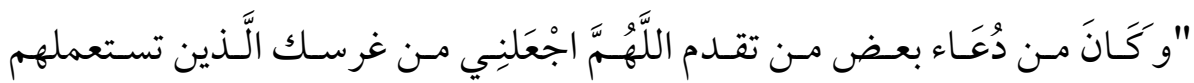

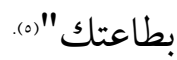
وهذا يدل على عظيم فضل من يستعمله الله في طاعته.

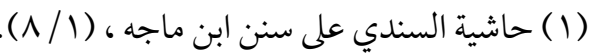

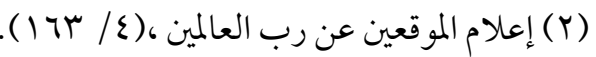

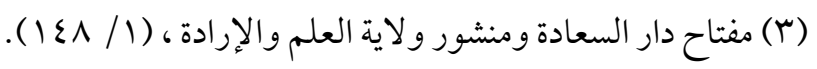

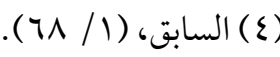

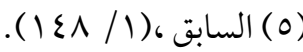




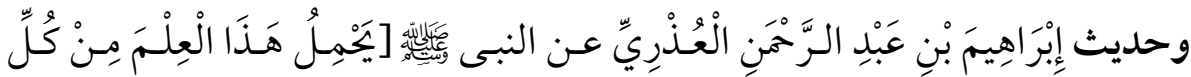

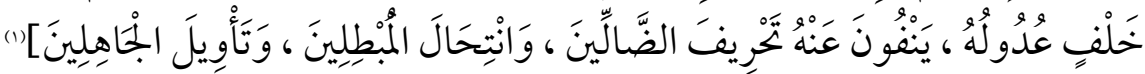

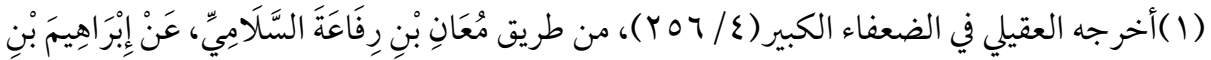

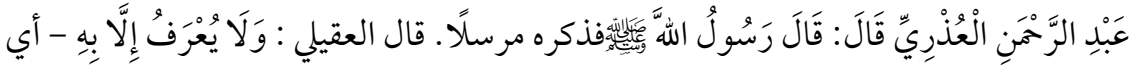

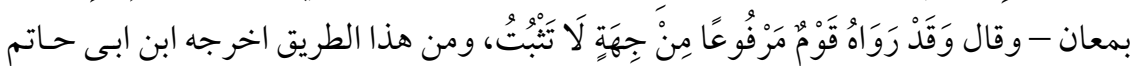

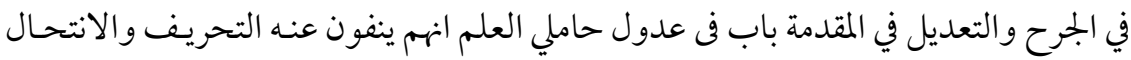

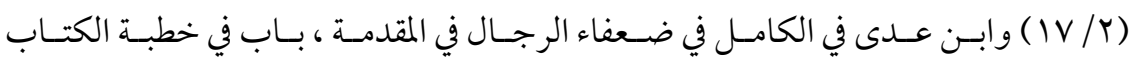
. ( $(Y) / 1)$

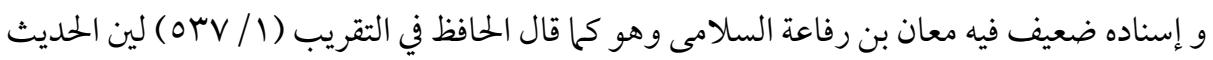

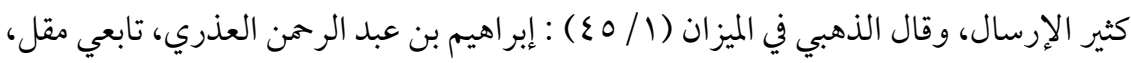

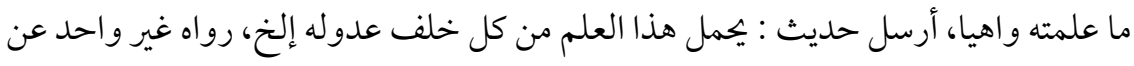

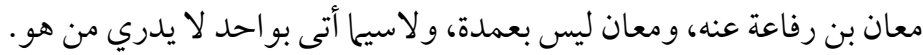

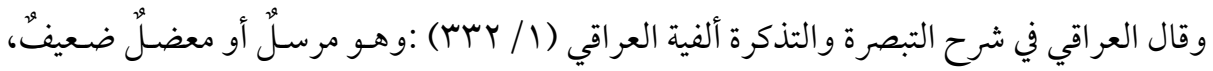

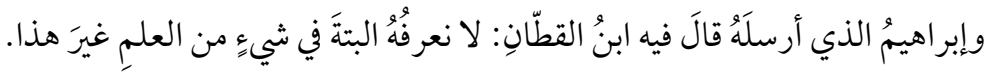

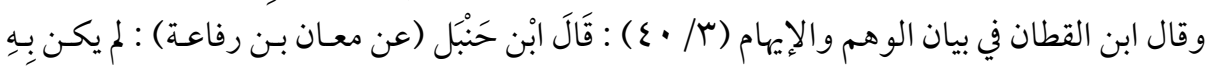

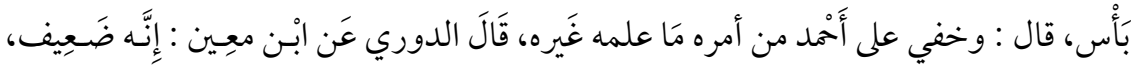

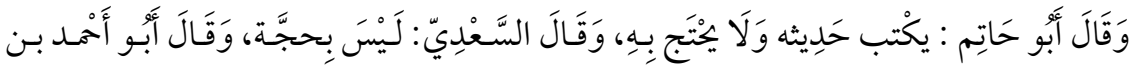

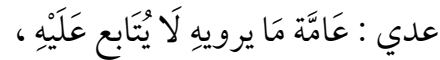

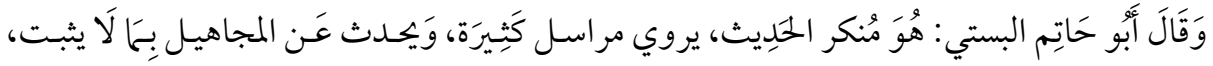

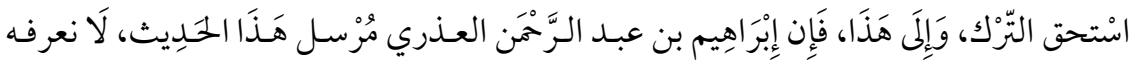

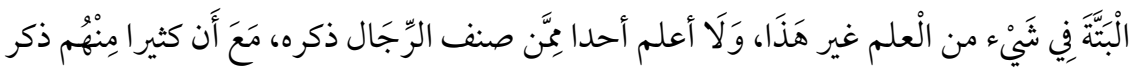

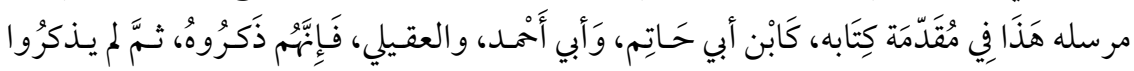

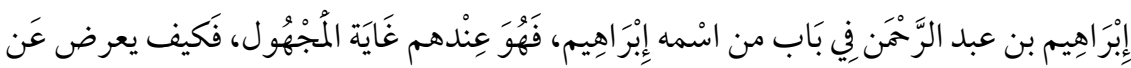

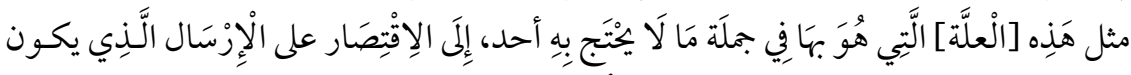

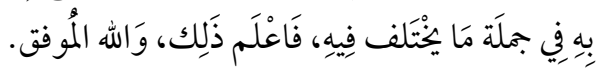
و الحديث قد روى عن جماعة من الصحابة مرفوعًا :

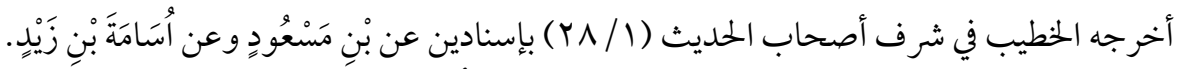

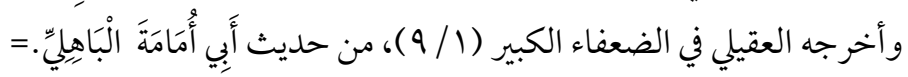




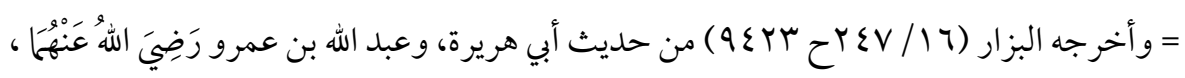

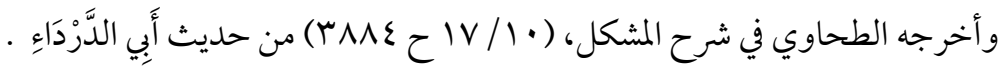
وأسانيدها ضعيفةٌ.

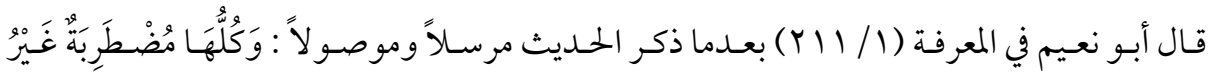

مُسْتَفِِمَة.

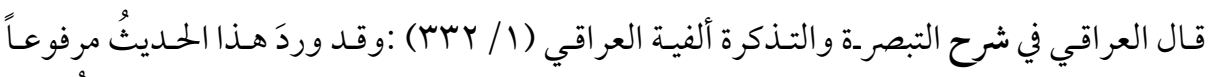

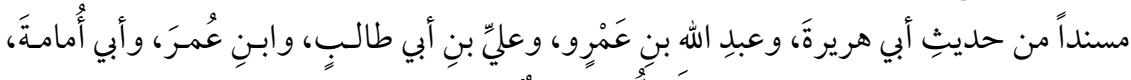

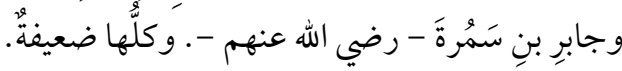

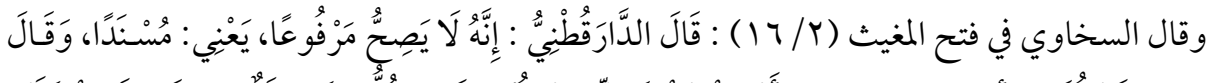

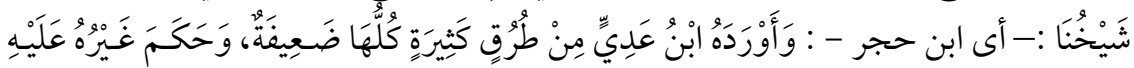

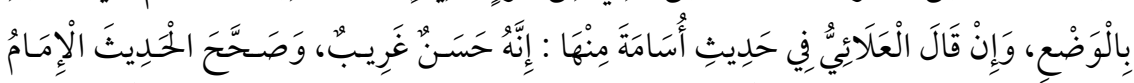

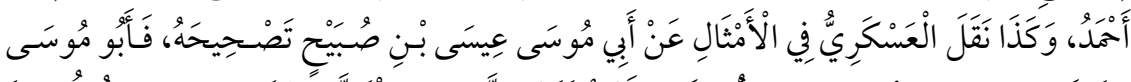

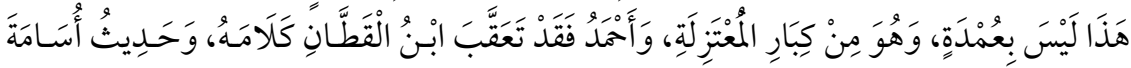

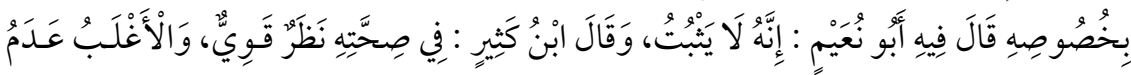

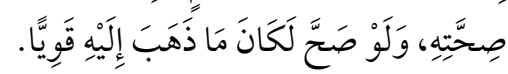

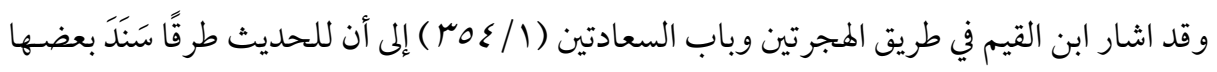
بعضاً.

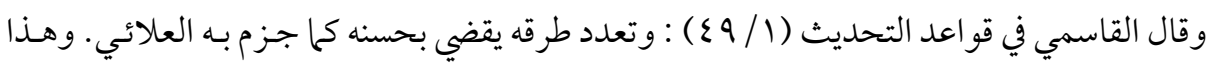

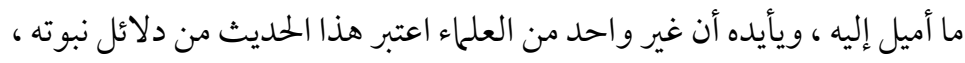

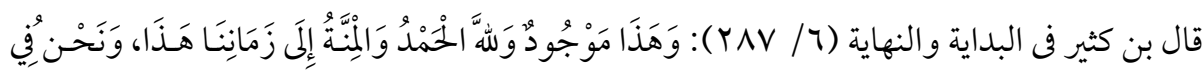

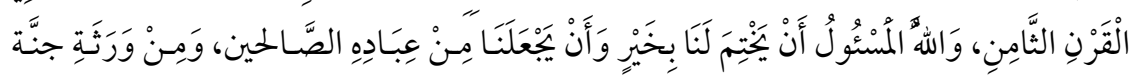

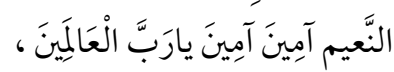

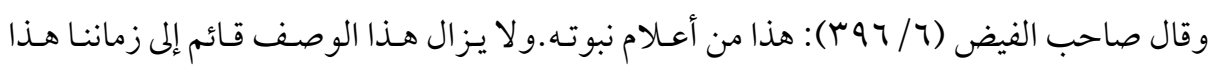

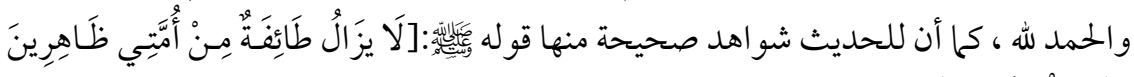

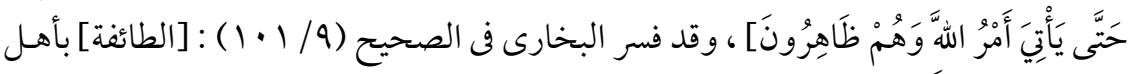

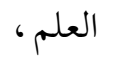

(1) شرح المشكاة للطيبي الكاشف عن حقائق السنن، (Y/ I (V). 


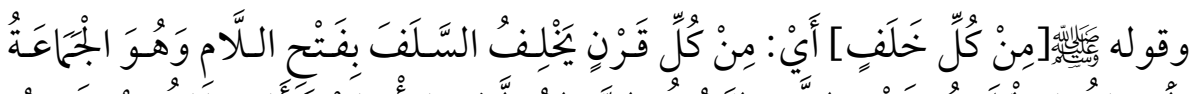

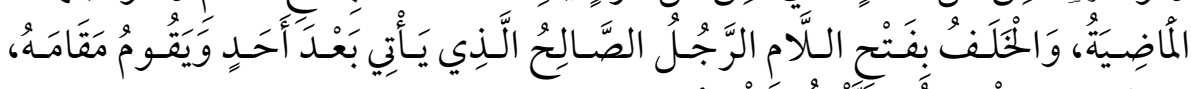

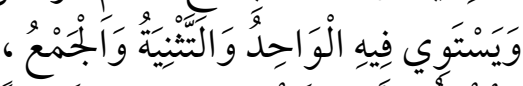

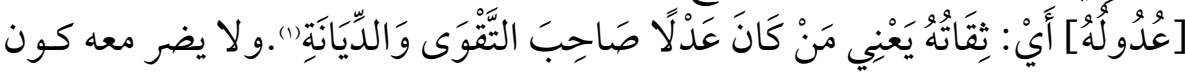

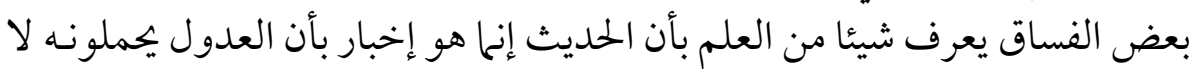
أن غيرهم لا يعرف منه شيئان).

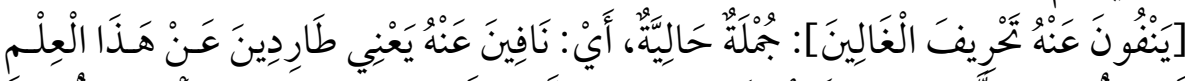

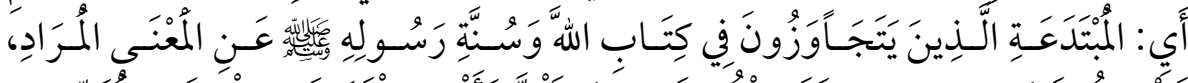

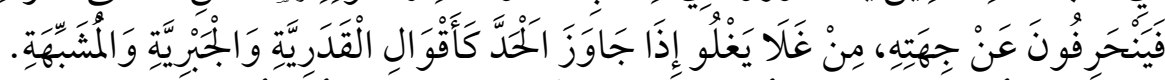

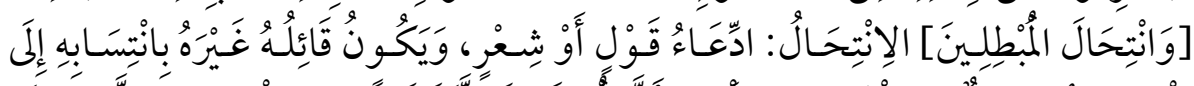

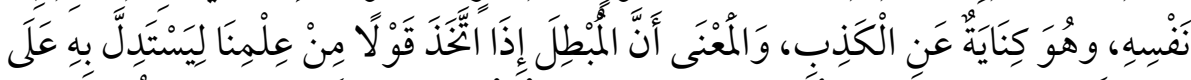

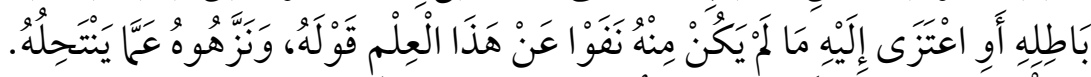

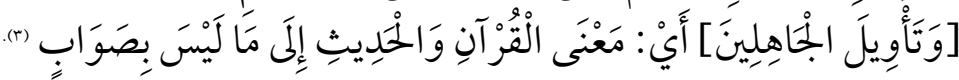

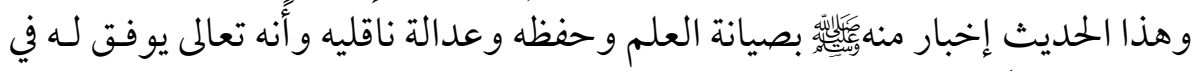

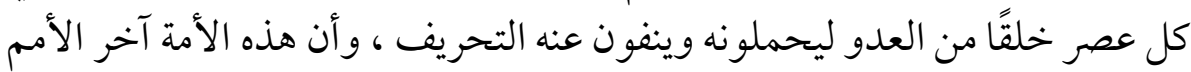

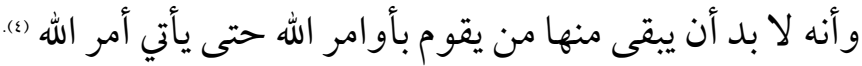

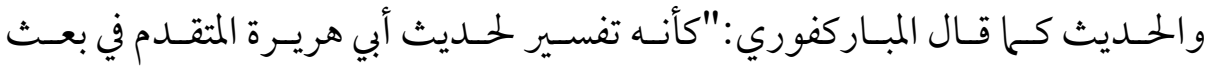

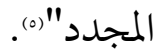

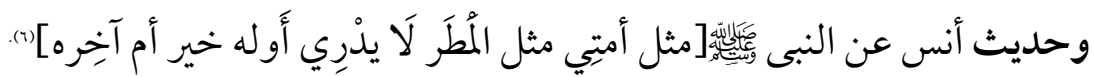

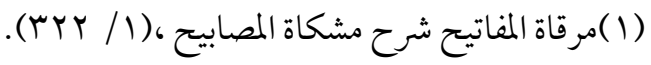

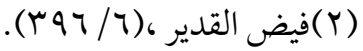

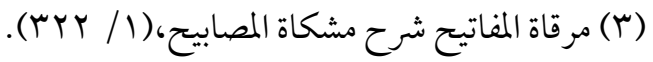

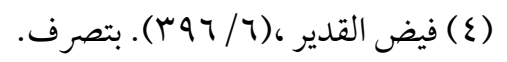

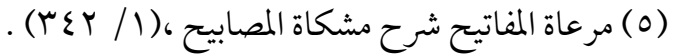

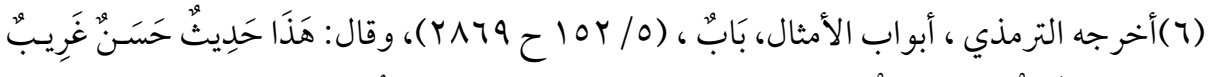

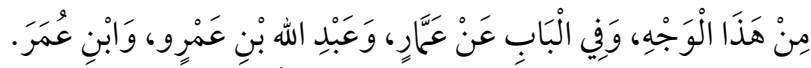

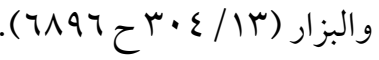

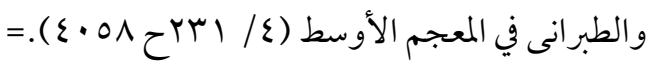




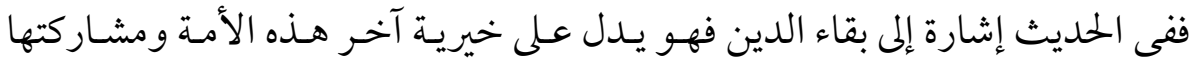

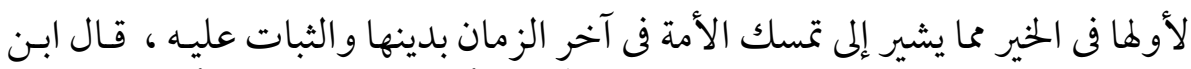

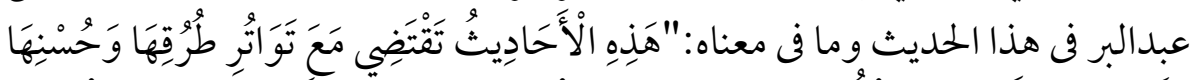

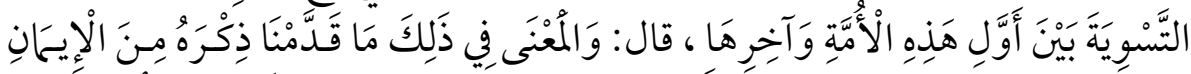

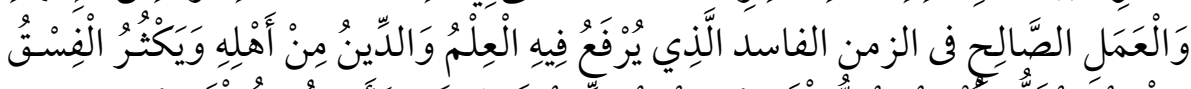

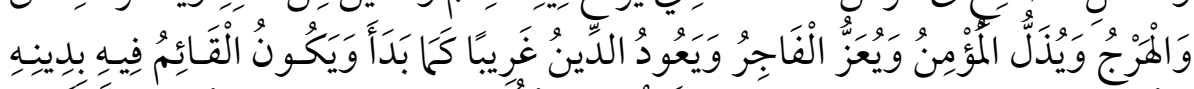

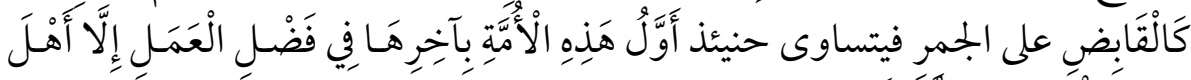

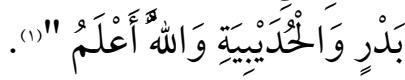

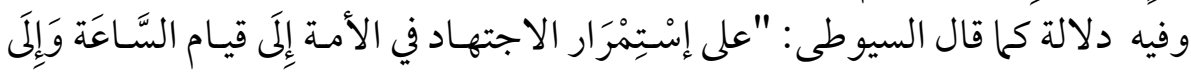

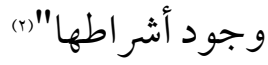

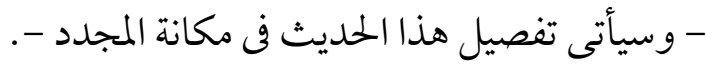

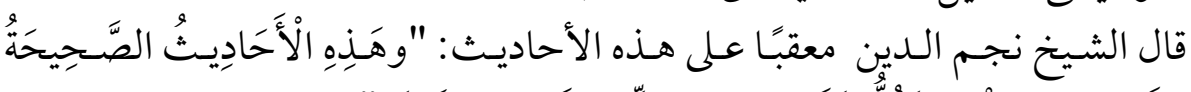

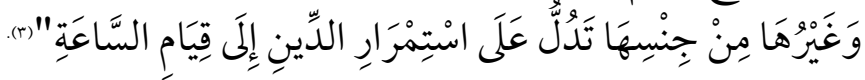

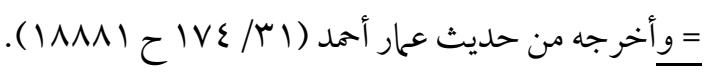

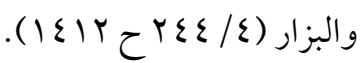

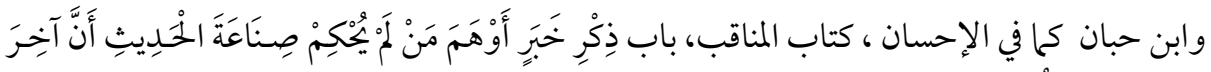

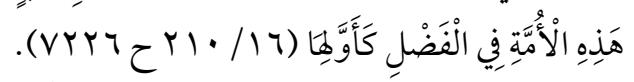

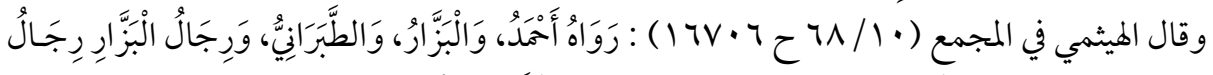

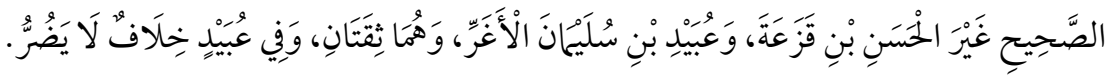

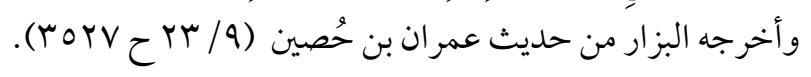

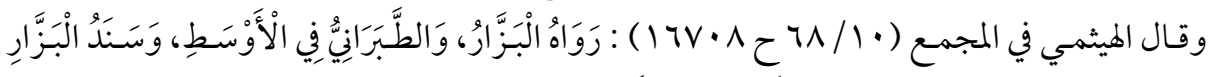

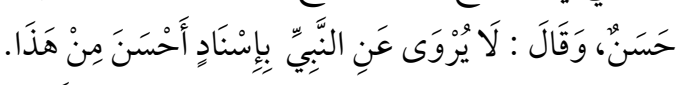

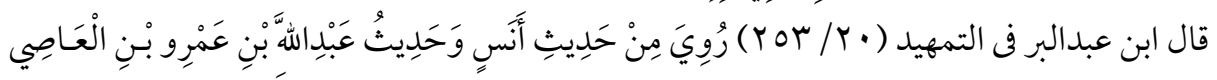

$$
\text { مِنْ وُجُوِوِ حِسَانِ. }
$$

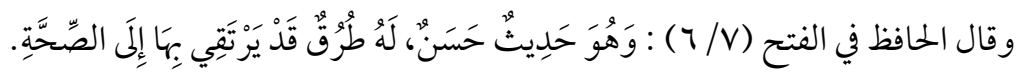

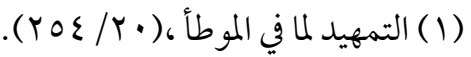

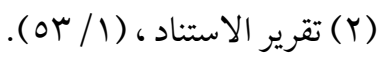

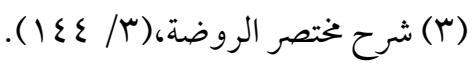




\section{المبحث السادس \\ أحاديث تتعارض فى معناها مع حديث الباب}

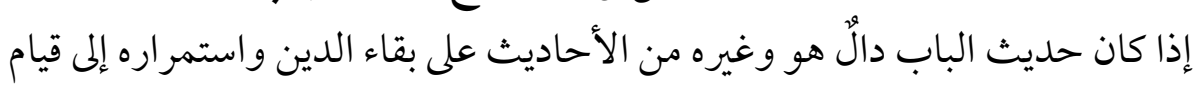
الساعة كما ذكرت في المبحث السابق.

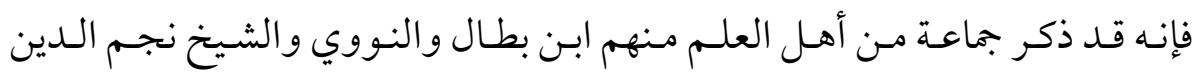

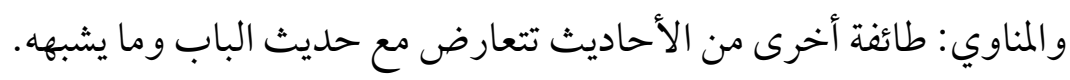

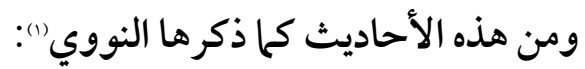

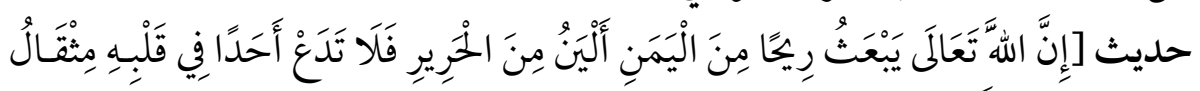

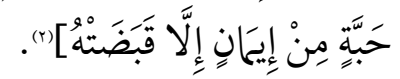

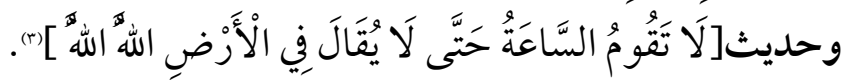

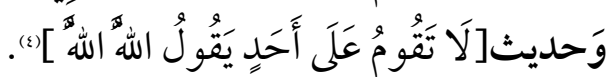

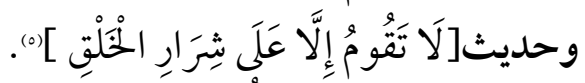

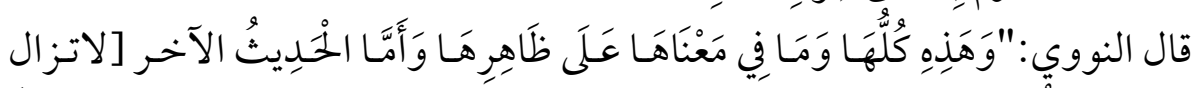

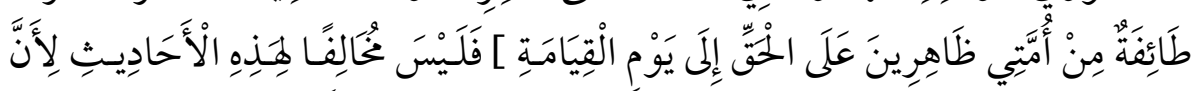

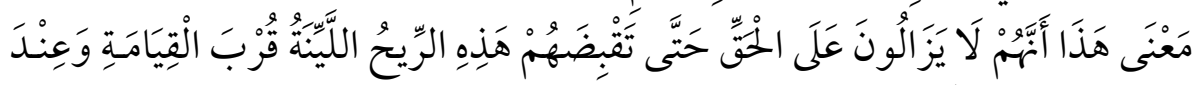

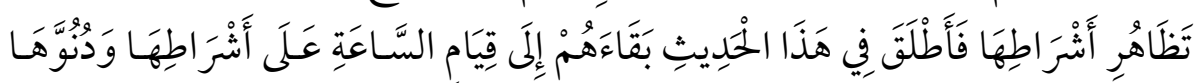

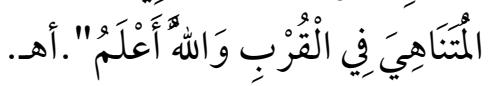

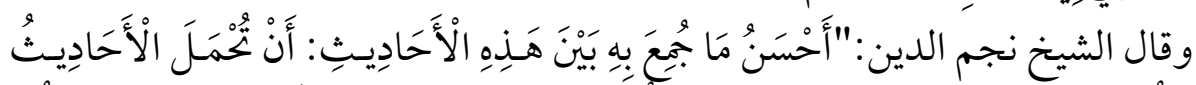

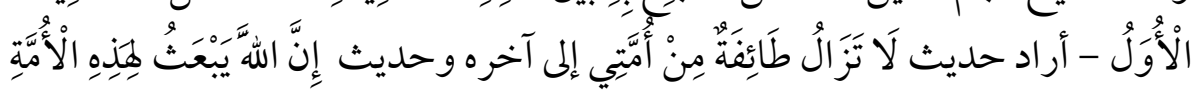

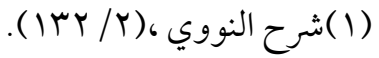

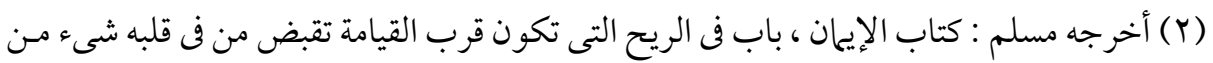

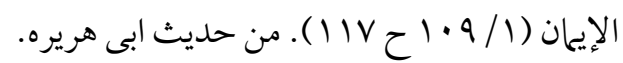

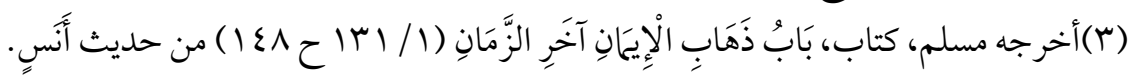

$$
\begin{aligned}
& \text { (ع) السابق نفسه. }
\end{aligned}
$$

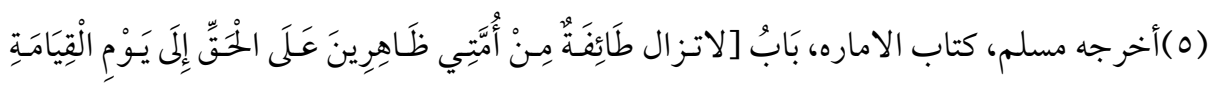

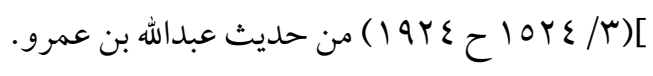




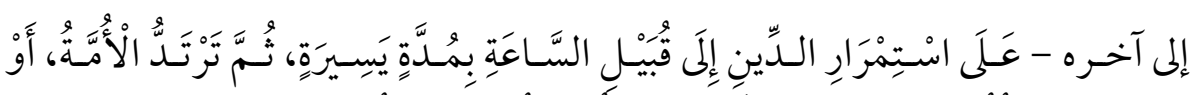

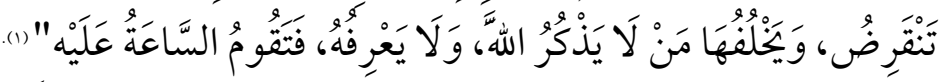

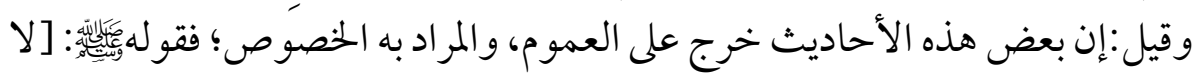

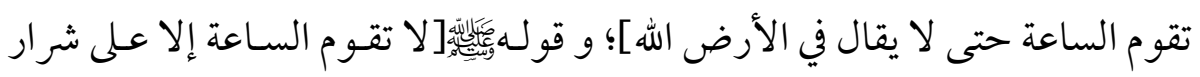
الناس يعنى: في موضع كذا، فإن به طائفة من أمتي لا يضرهم من خالفهم () .

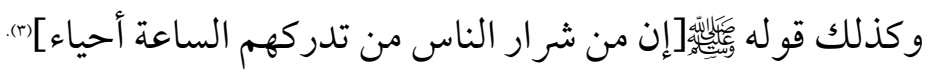

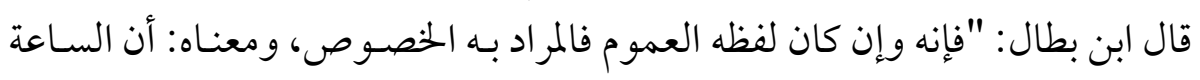

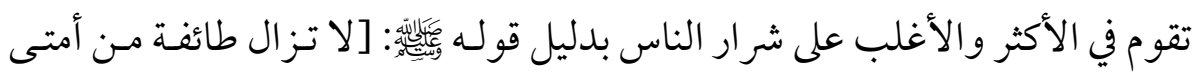

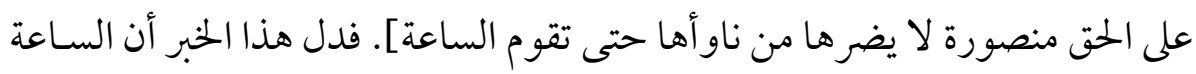

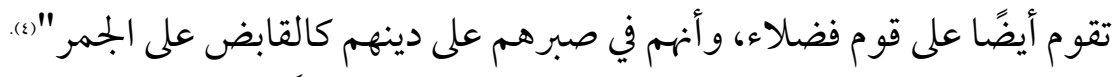

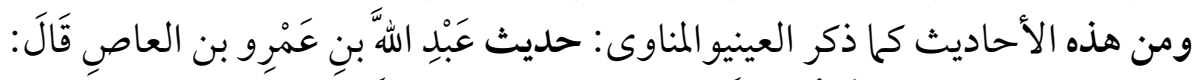

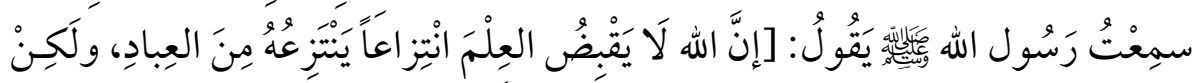

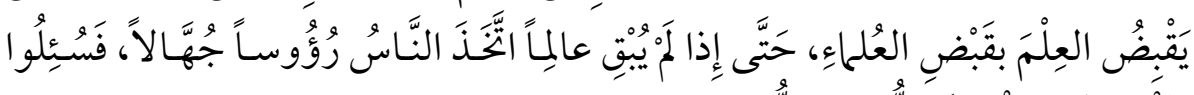

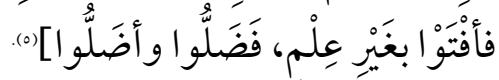

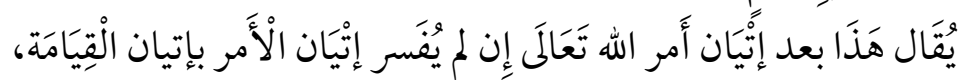

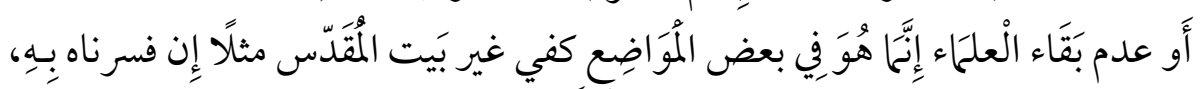

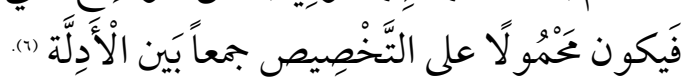

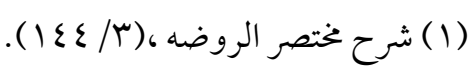

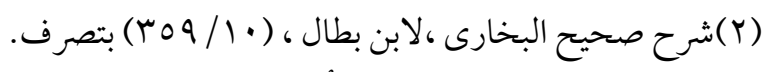

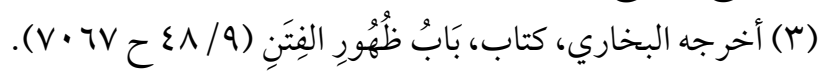

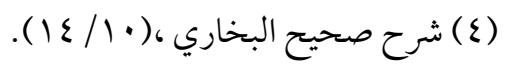

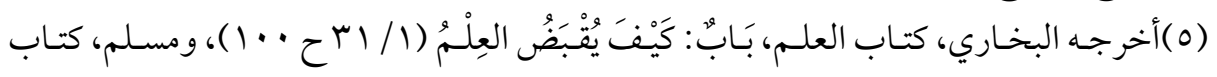

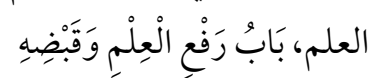

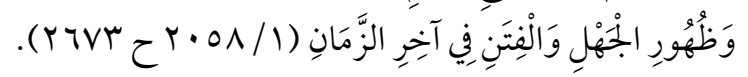

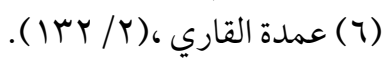


=

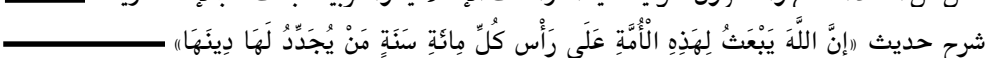

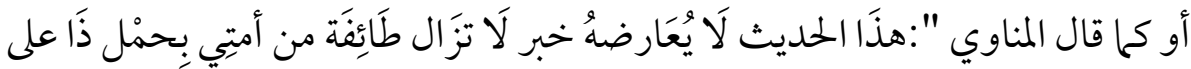

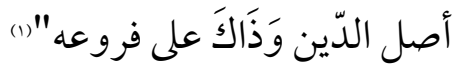

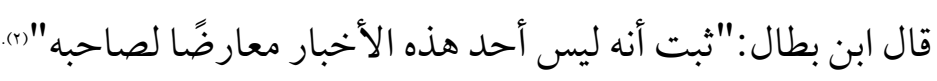

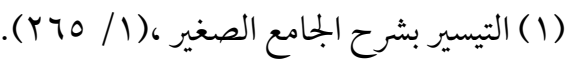

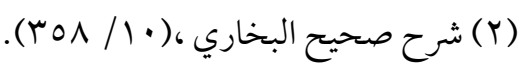

ב 
$$
\text { المبحث السابع }
$$

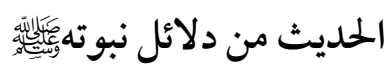

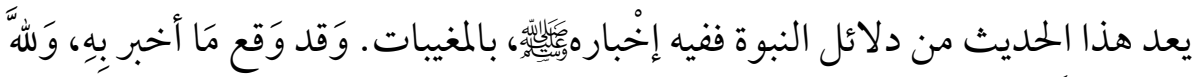

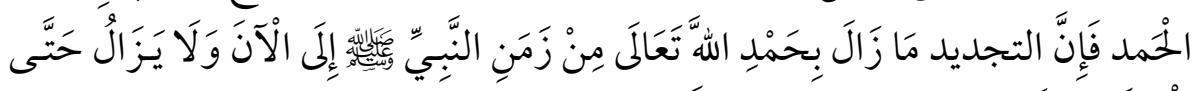
يَأْتِيَ أَمْرُ اللَّهَ،

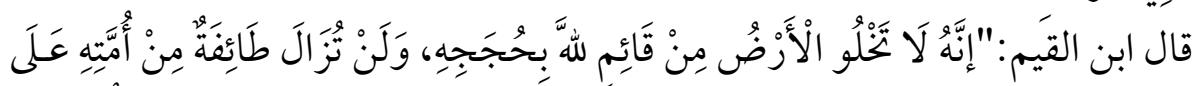

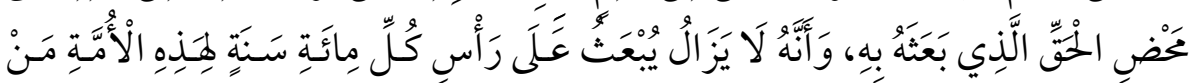

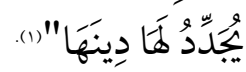

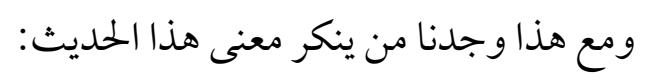

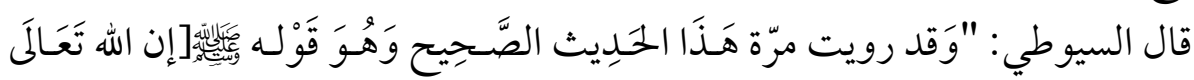

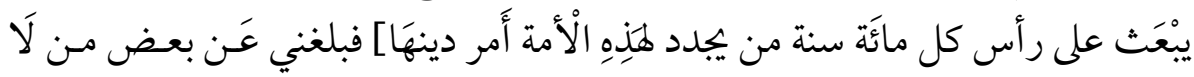

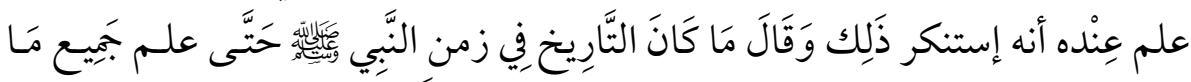

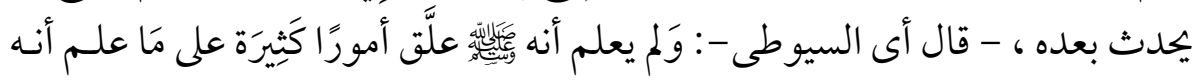

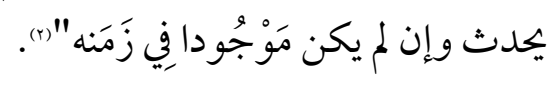

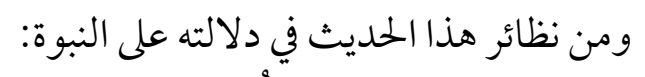

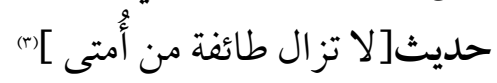

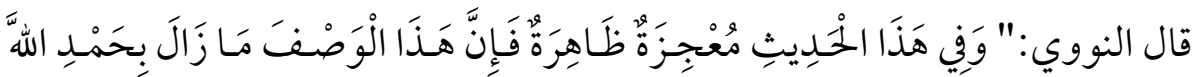

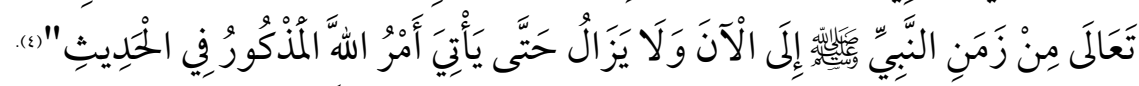

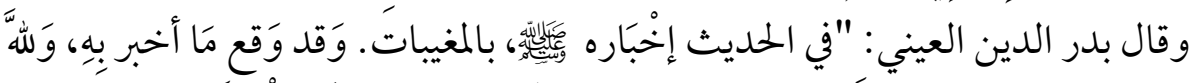

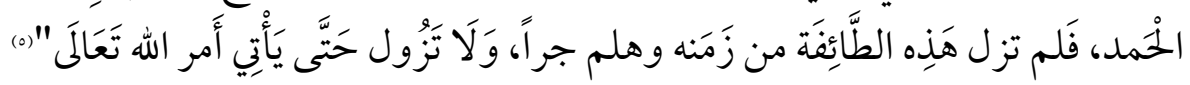

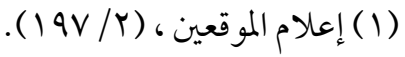

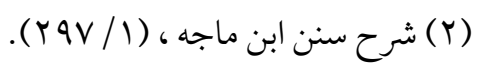

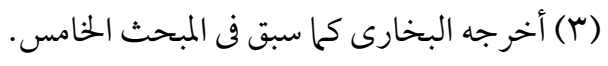

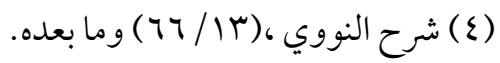

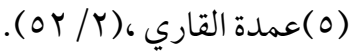




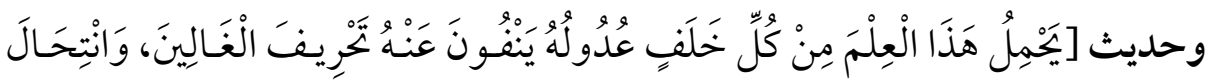

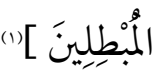

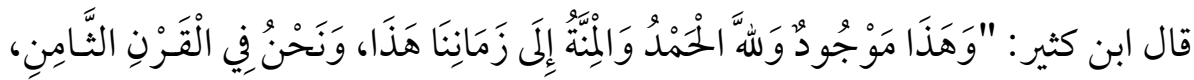

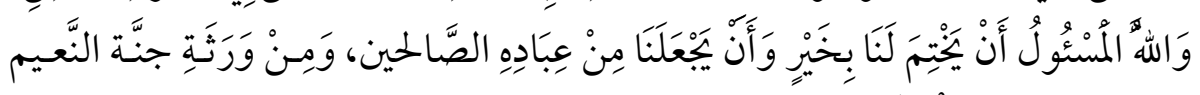

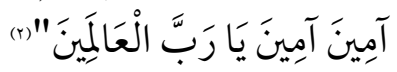

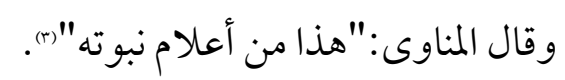
ولا يزال ذلك بفضل الله تعالى إلى هذا الزمان.

$$
\begin{aligned}
& \text { (1) سبق تخريجه والحكم عليه فى المبحث الخامس. }
\end{aligned}
$$

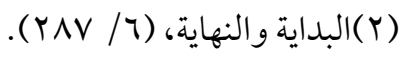

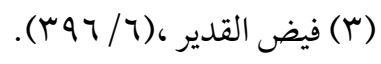




\section{المبحث الثامن \\ تجديد الإيهان}

يشير الحديث إلى ضرورة الاعتناء بأمر الدين وإصـلاح مافسـد منهه ومـدى عنايـة الله

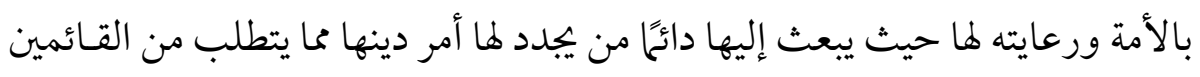

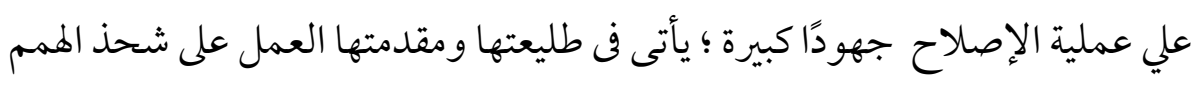

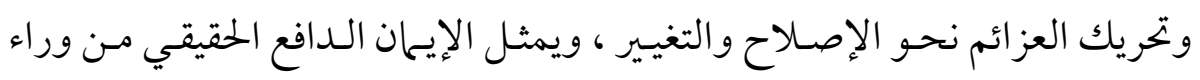

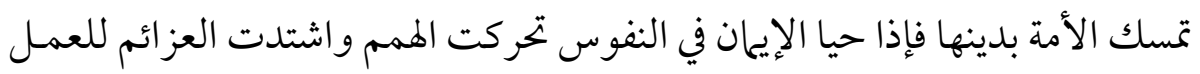

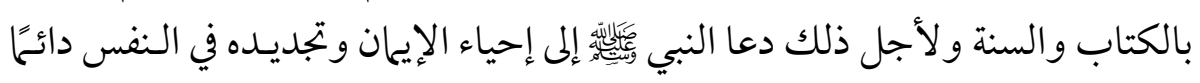

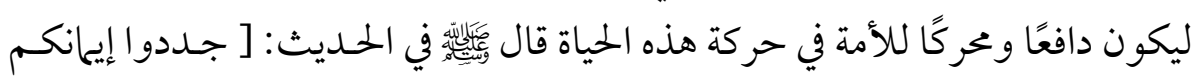

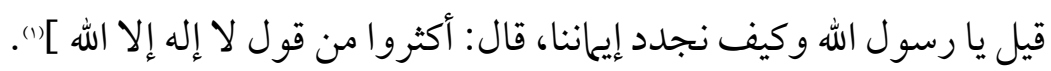

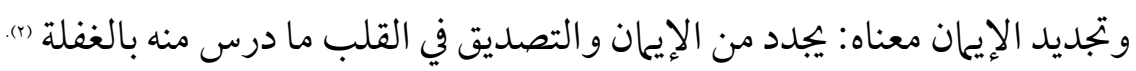

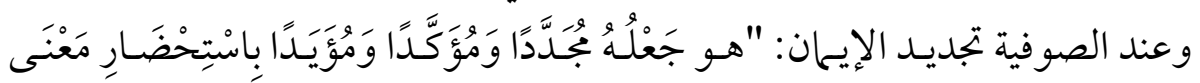

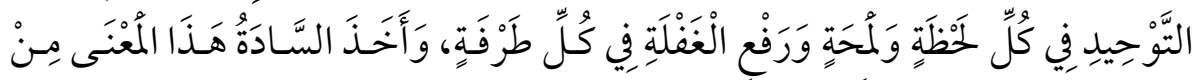

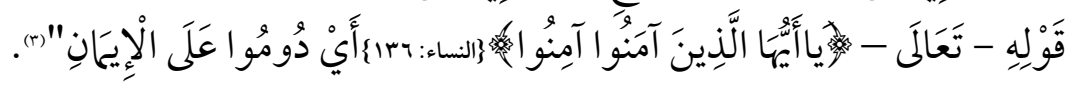

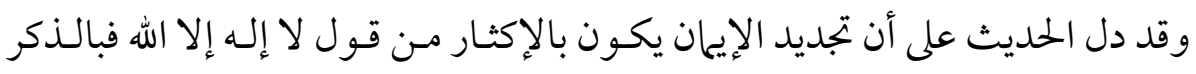

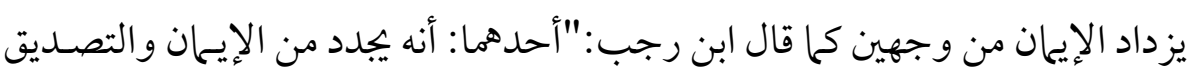

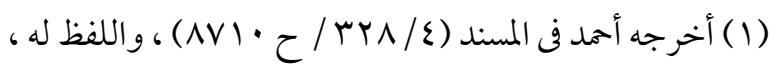

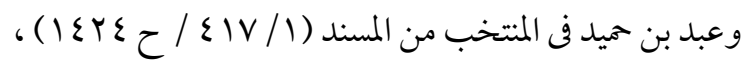

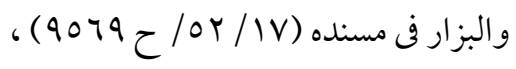

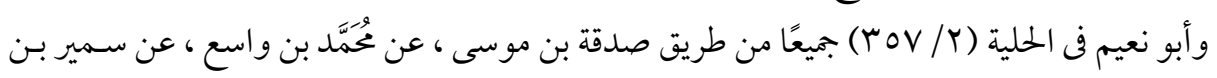

$$
\text { نهار ، عَنْ أَبِي هُرَيْرَةَ. }
$$

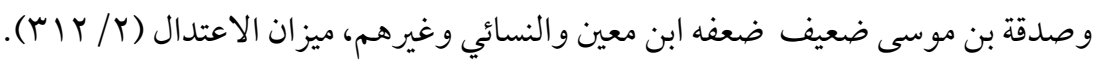

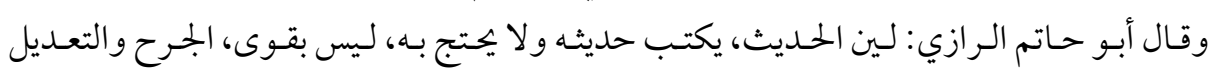

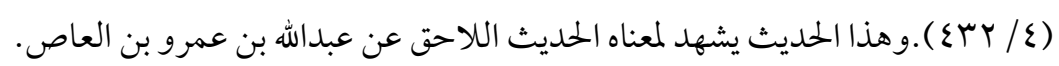

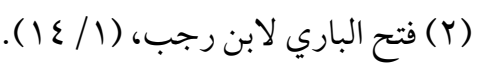

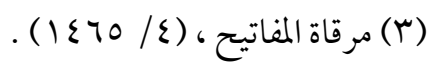


في القلب ما درس منه بالغفلة كما قال ابن مسعود: الذكر ينبـت الإيهان في القلب كما ينبت الماء الزرع.

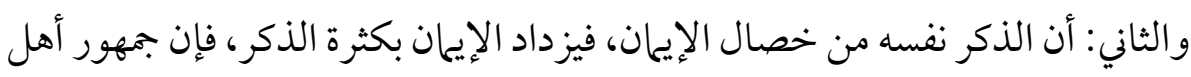

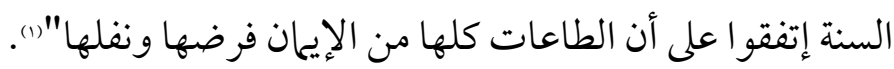

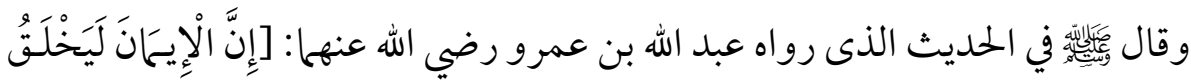

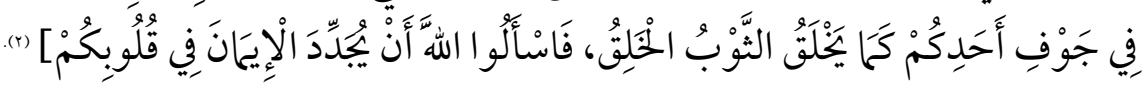

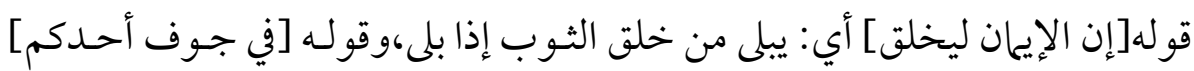

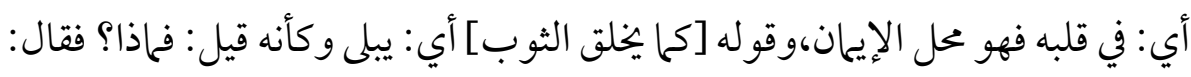

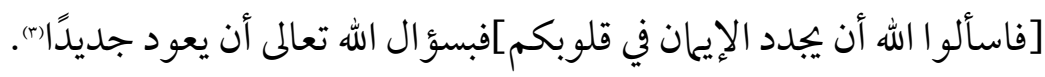

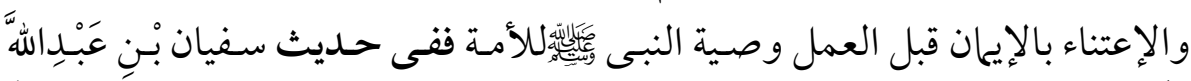

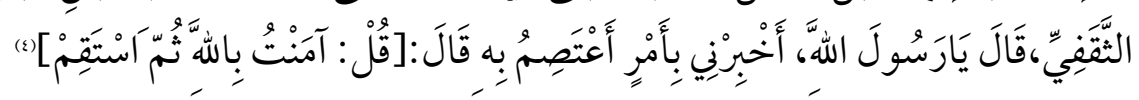

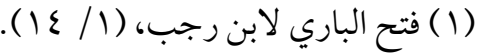

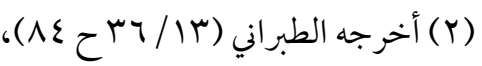

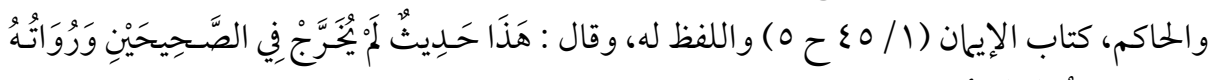

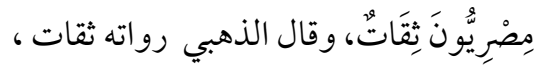

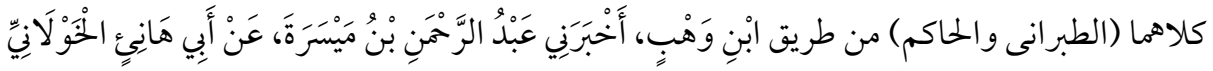

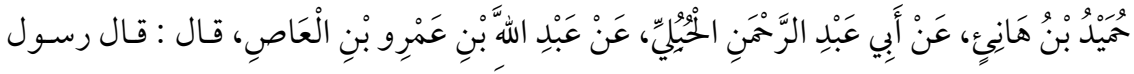

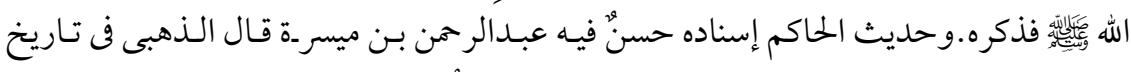

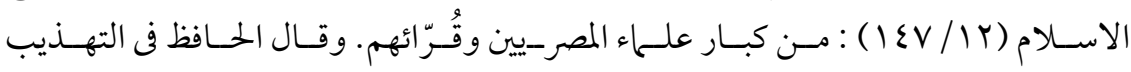

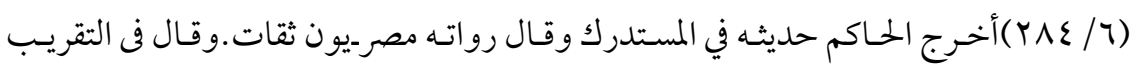

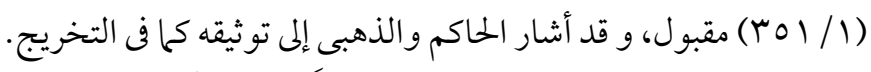

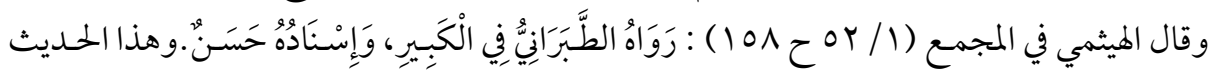
أيضًا يشهد لمعناه الحديث السابق.

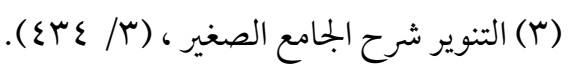

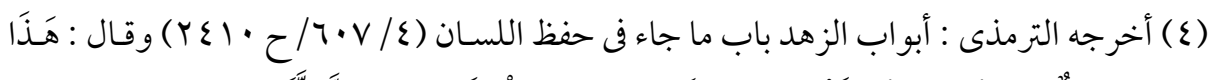

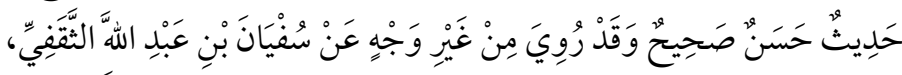

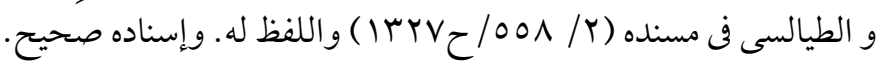




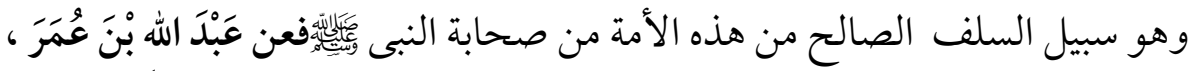

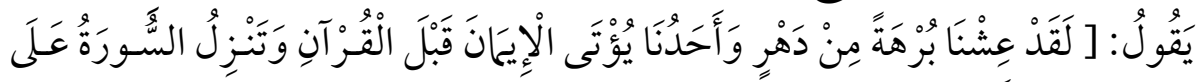

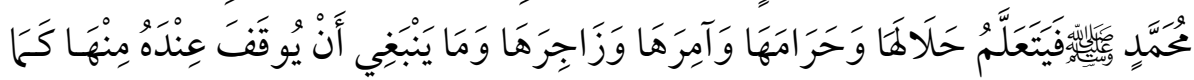

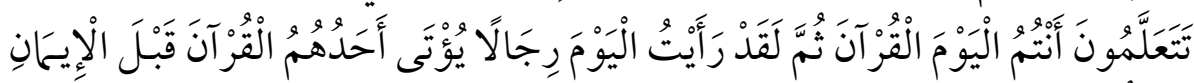

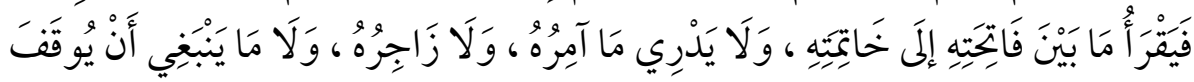

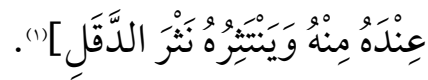

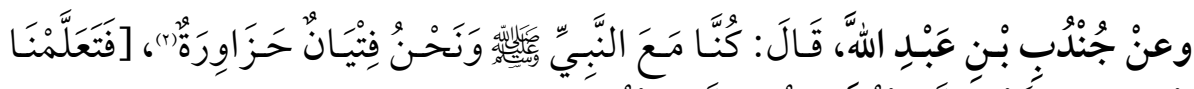

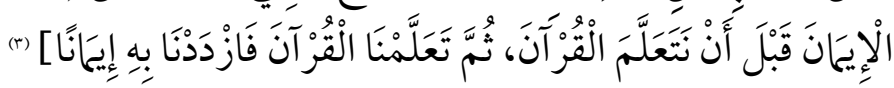

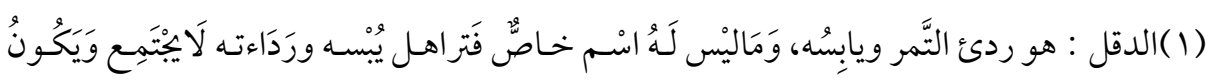

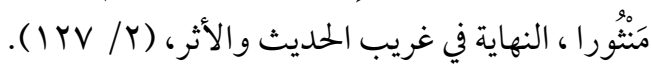

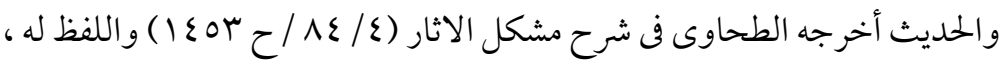

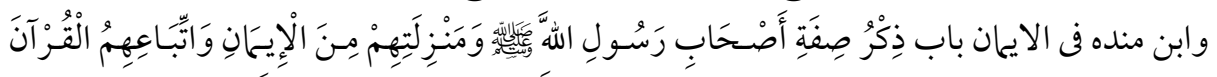

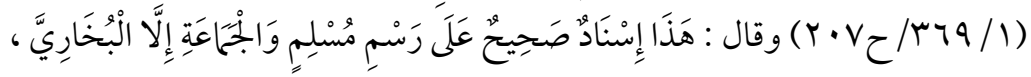

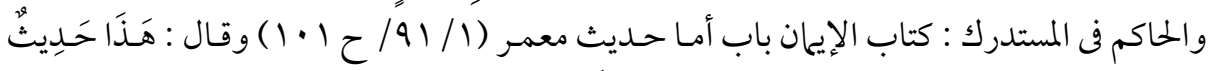

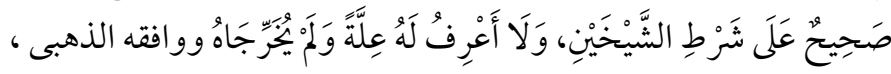

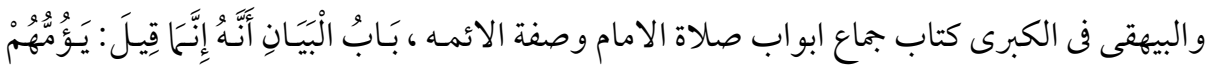

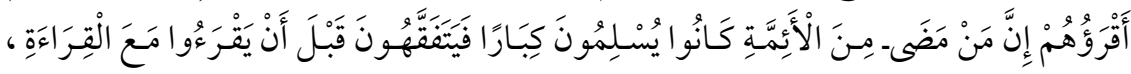
، (orq. $\tau^{/ 1 V \cdot / r)}$

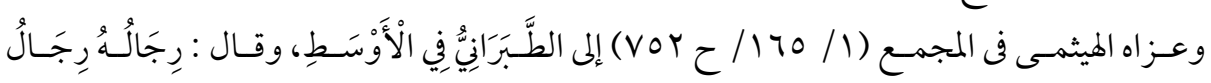
الصَّحِيحِ.

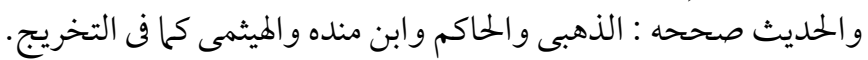

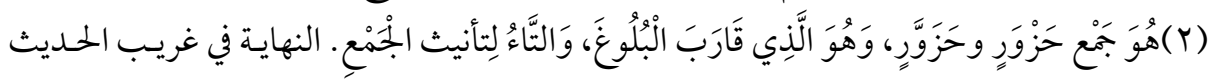

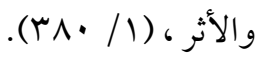

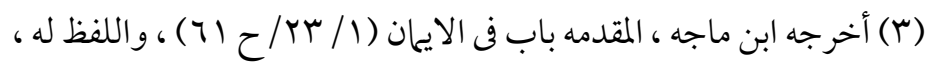

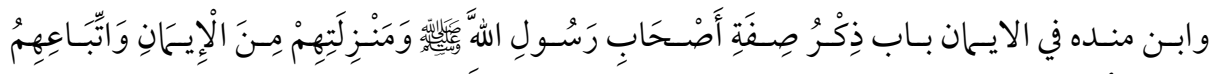

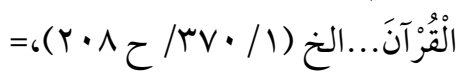


=

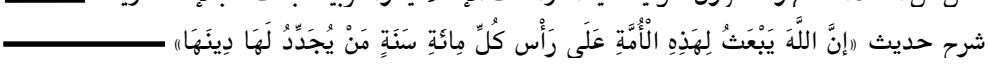

ففي هذه الأحاديث دعوة للمصلحين من هذه الأمة إلى إحياء الإياان في النفوس أولاًا

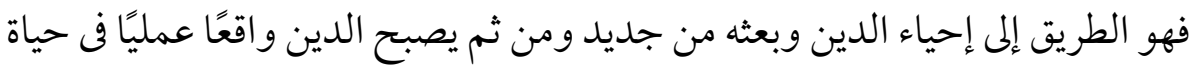

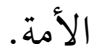

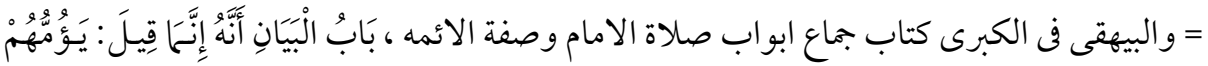

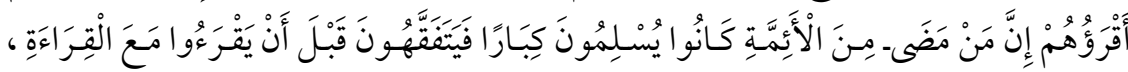

$$
\text { ،orar C/IVI/r) }
$$

والحديث صحح إسناده البوصيرى في الزوائد (IV/ I / ) ).

= orv 


\section{المبحث التاسع \\ شروط المجدد}

لم يرد في أي من الأحاديث النبوية ذكر شيء من شروط إلمجد المجدد وقد آل الأمر كاملاً في

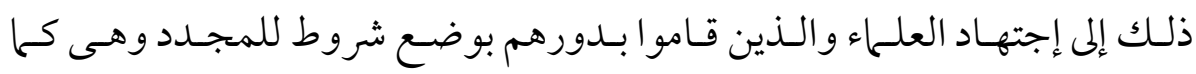
تضمنتها أقو الهم على النحو الآتي:

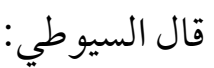

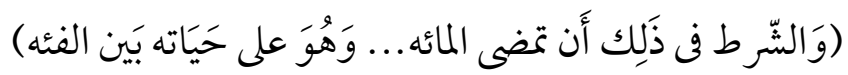

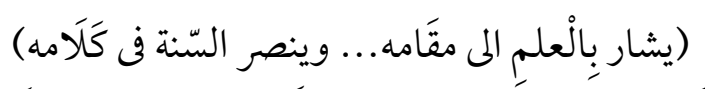

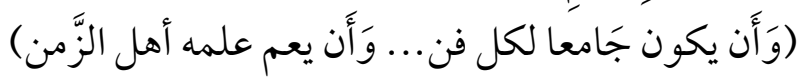

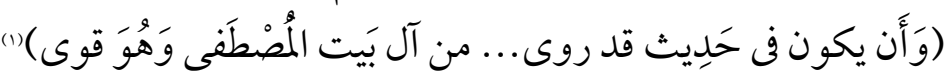

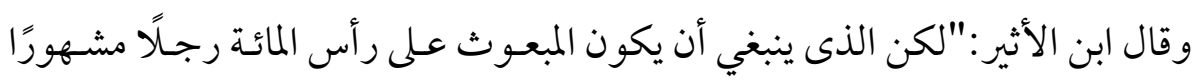

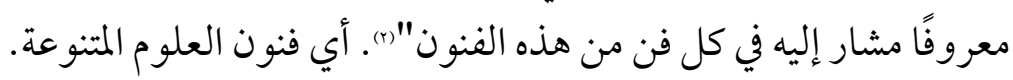

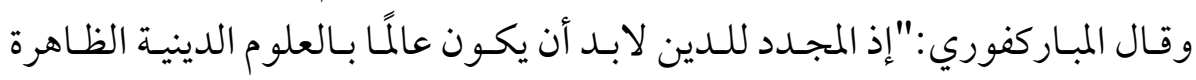

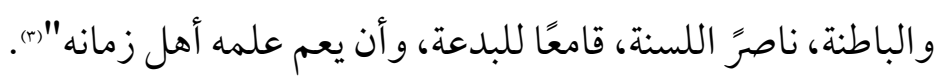

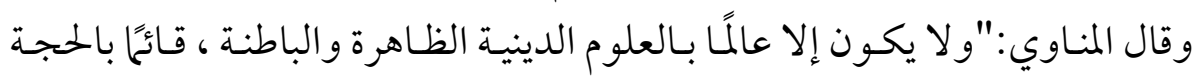

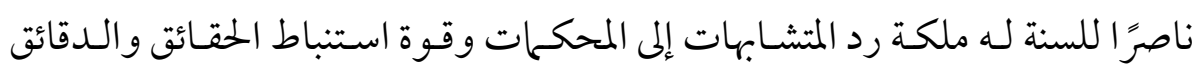

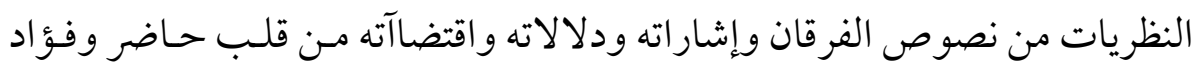
يقظان" (s).

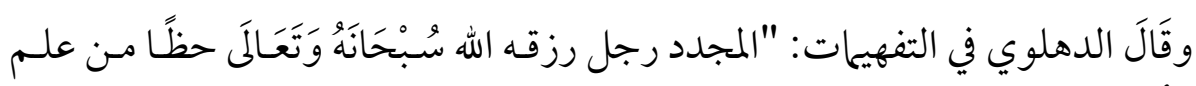

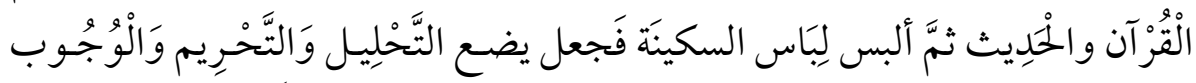

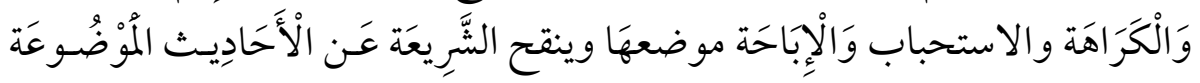

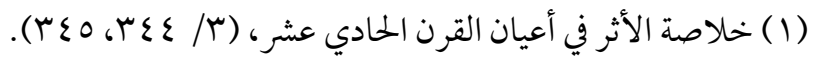

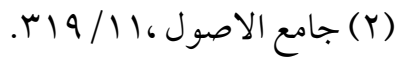

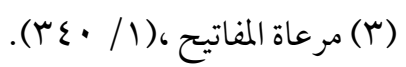

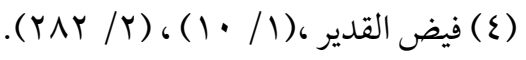




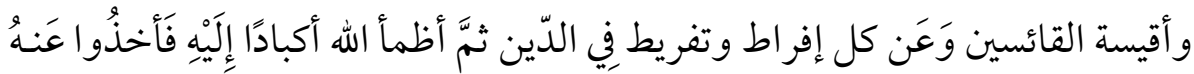
الْعلم".

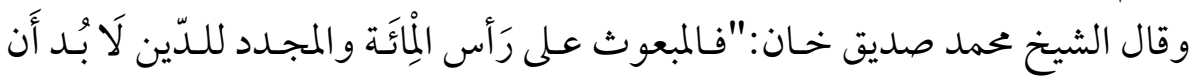

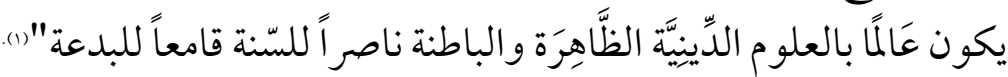

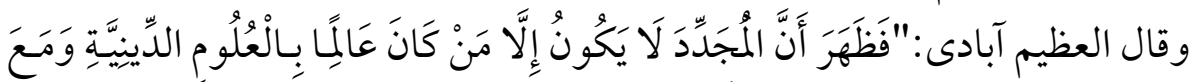

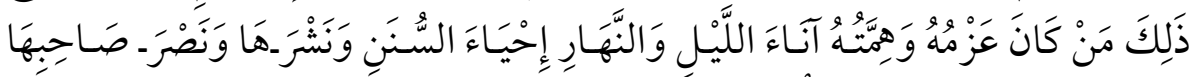

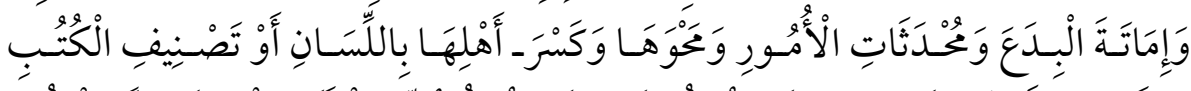

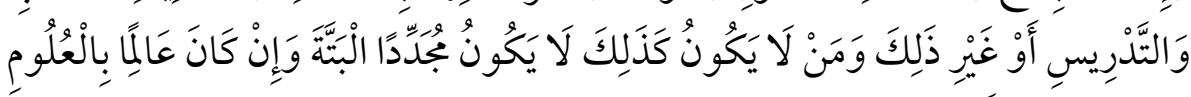

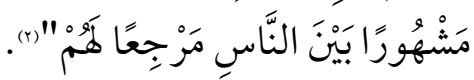

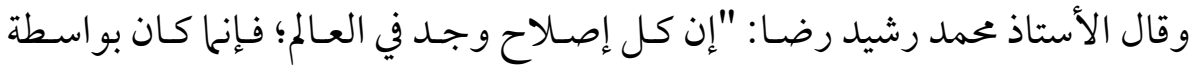

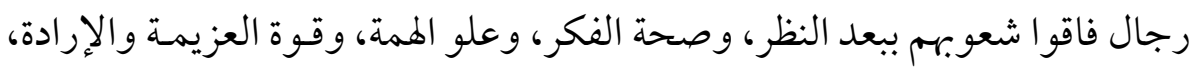

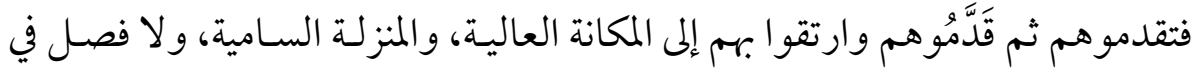

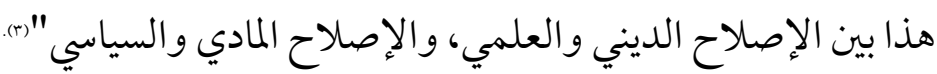

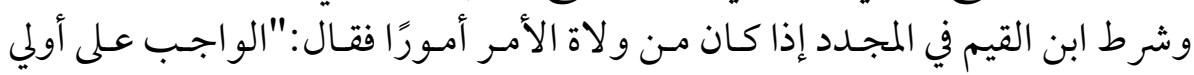

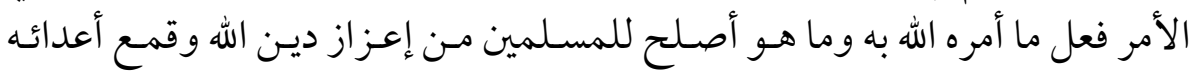

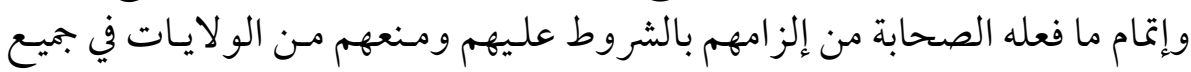

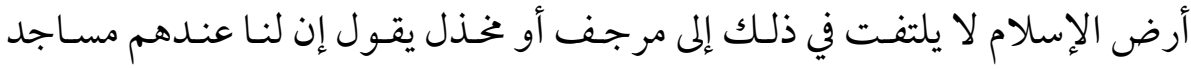

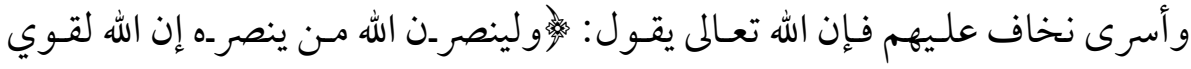

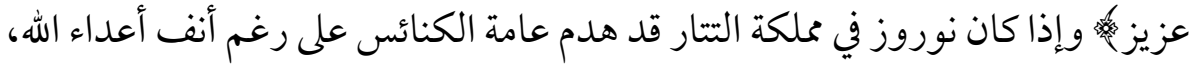

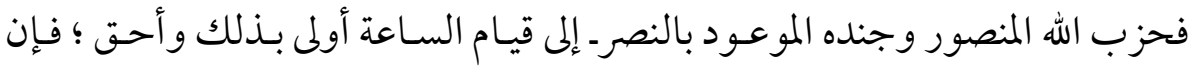

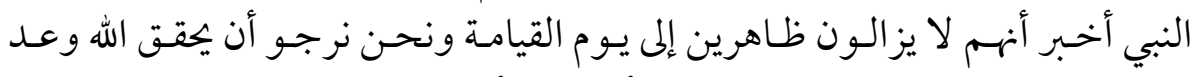

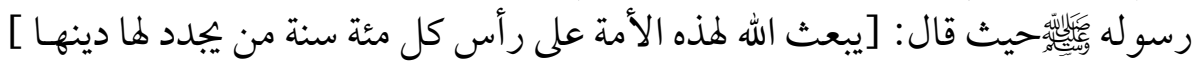

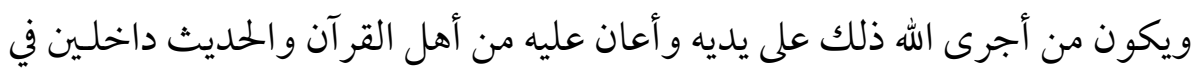

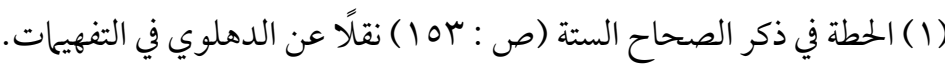

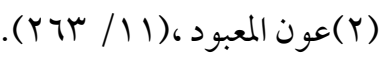

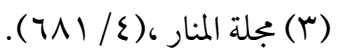




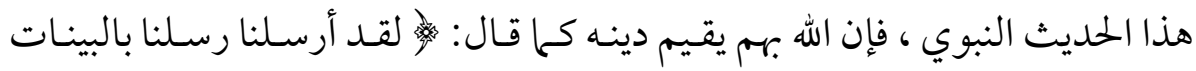

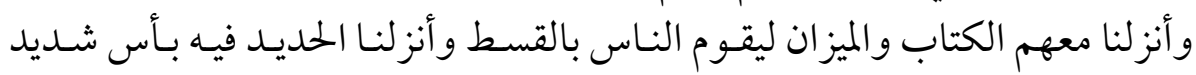

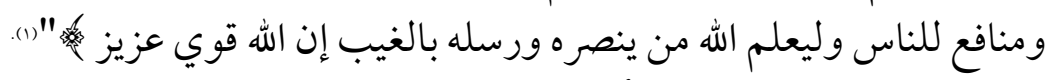

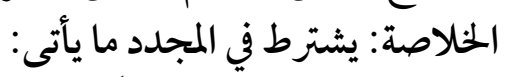

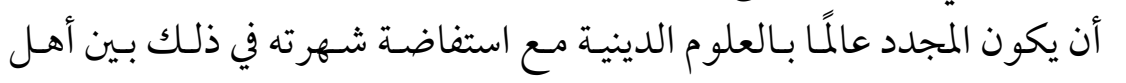
عصرم. هـ أن يعم نفعه ، وينتشر ـ علمـه في الآفـاق ويتـأثر بـهـ أهـل زمانـه في سـائر الأقطـار والأمصار. " أن يكون ناصرًا للسنة و أهلها.

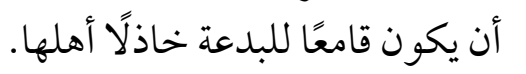

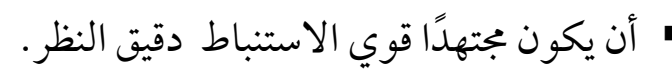
• أن يكون حاضر القلب يقظ الفؤ اد عنده ملكة الرد على المخالفين للحق الفئ.

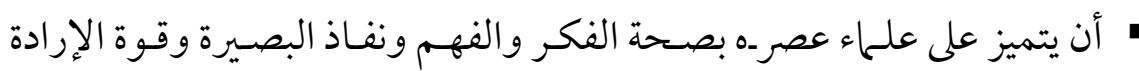
و الفمة العالية. • أن يكون متصفًا بكل فضل. أن يعمل على إعزاز الدين ورفع رايته و كسر ـ شـو كة أعدائه متمكنًا مـن إظهـار

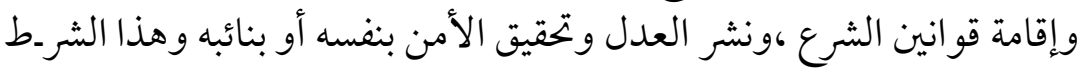
يكون في الحكام والأمراء.

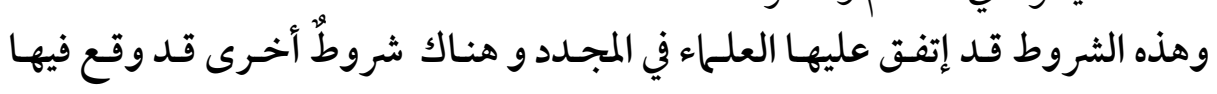
إختلاف وهي: اشترط بعضهم أن يكون المجدد على رأس المائة.

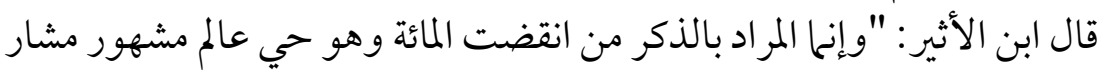
إليه "(r) وقال الطيبي: "وإنها المراد بالذكر ذكر مـن انقضـت المائة وهـو حي عـالم مشـار إليه "(r)

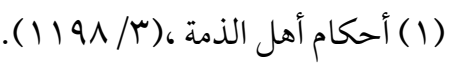

$$
\begin{aligned}
& \text { (Y) جامع الأصول، (1)/19/1) }
\end{aligned}
$$

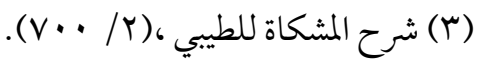


وقال الكرماني: "وقد كان قبل كل مائة أيضًا من يصحح ويقوم بأمر الدين وإنما

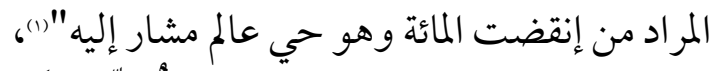

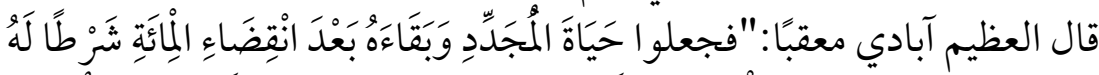

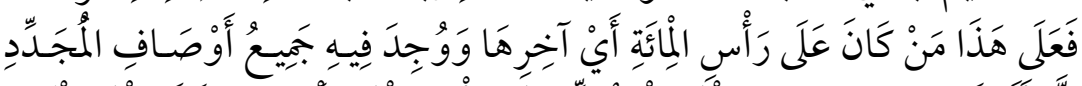

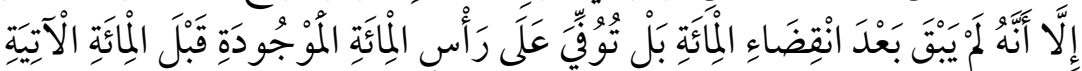

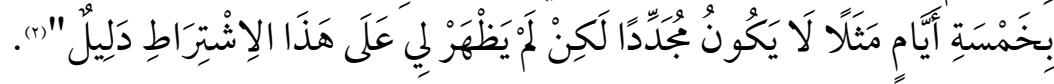

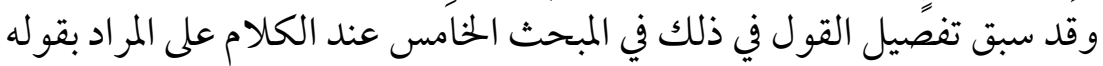

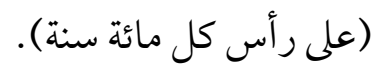

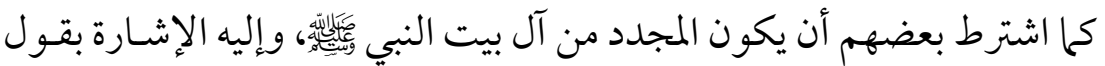

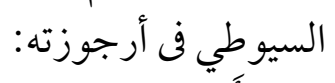

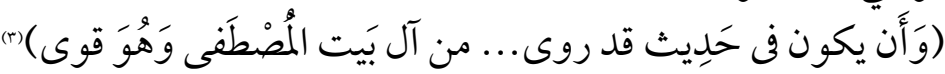

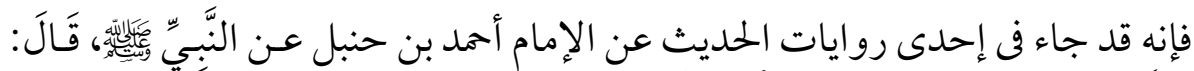

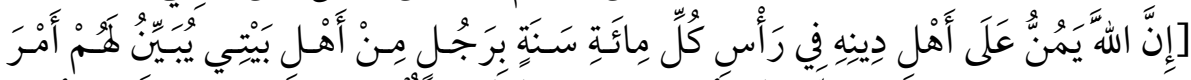

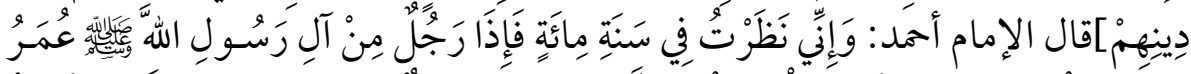

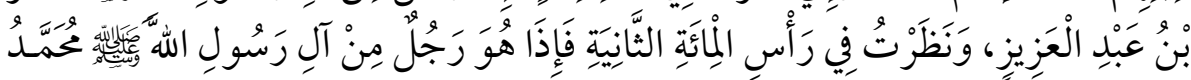

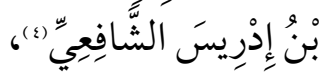

$$
\begin{aligned}
& \text { قال السبكى : وَهَذَا ثَابت عَن الإِمَام آَحْمَدَ سقى اللَّ عَهُهده } \\
& \text { (1) الكو اكب الدراري (I/ / (Y (Y). }
\end{aligned}
$$

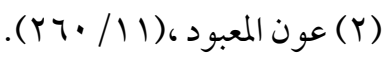

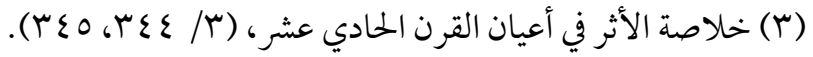

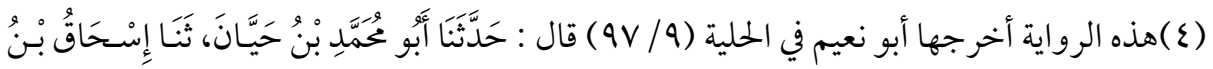

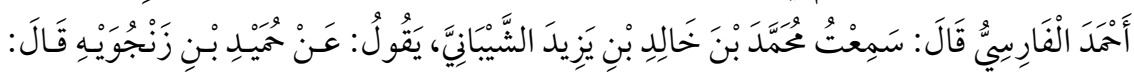

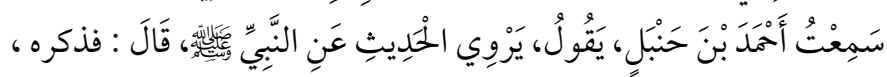

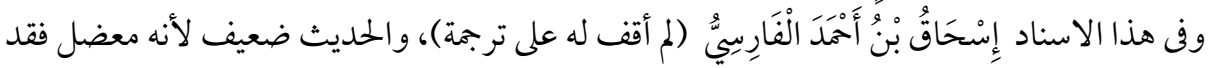

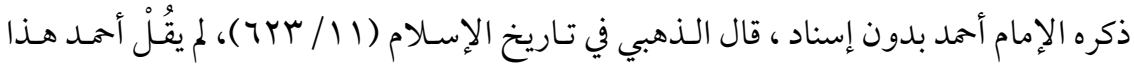

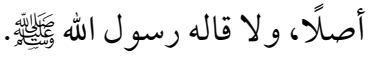

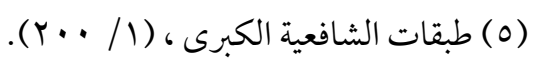




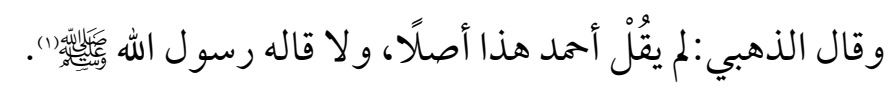

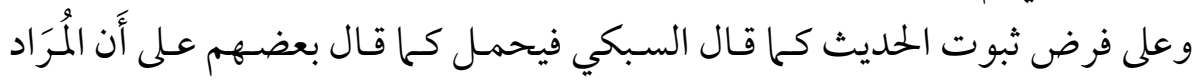

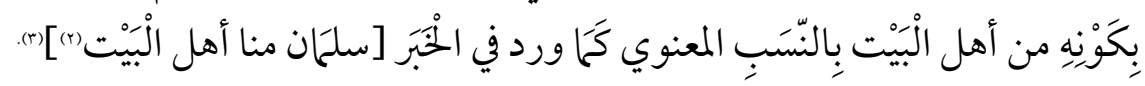

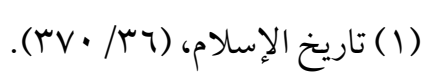

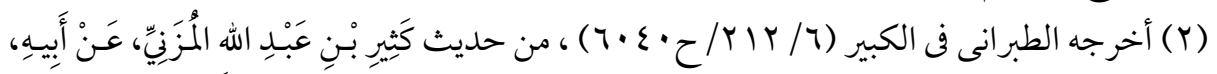

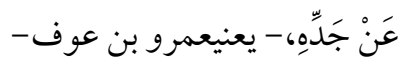

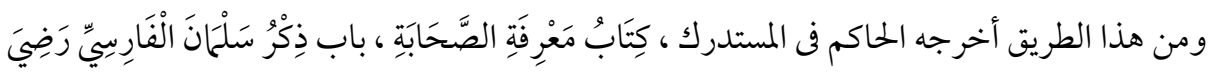

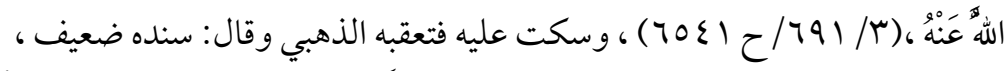

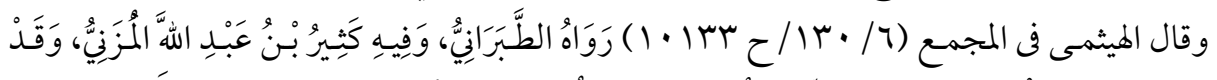

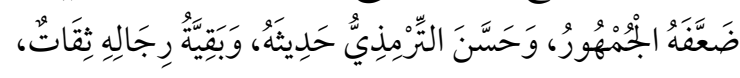

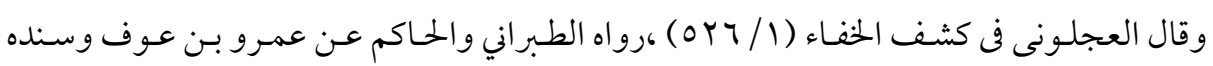

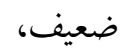

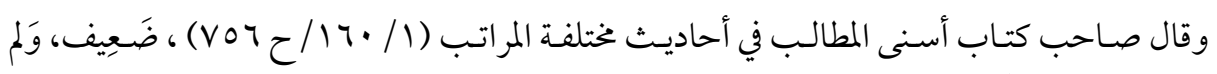

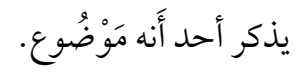

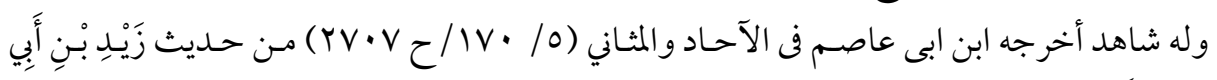

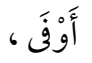

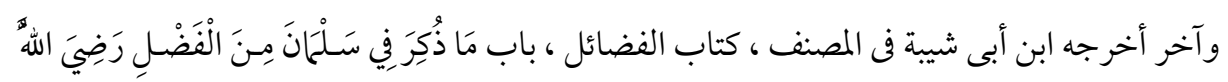

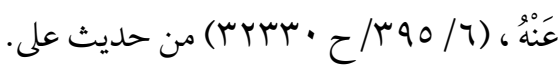

(r) خلاصة الأثر، (r) (r) (r) 


\section{المبحث العاشر \\ مكانة المجدد}

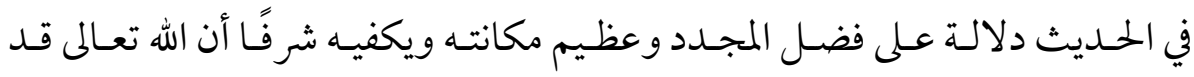

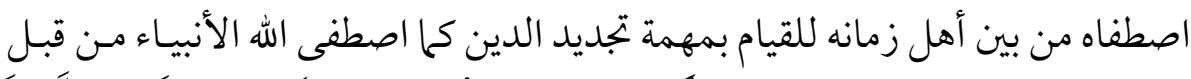

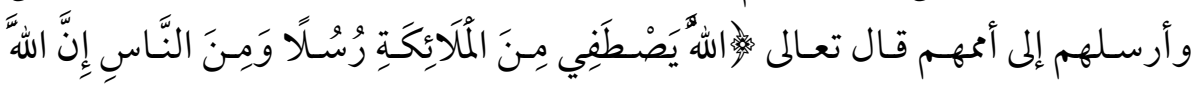

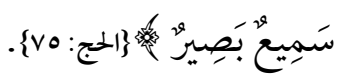

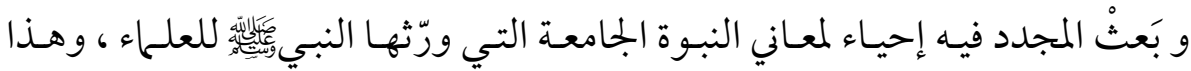

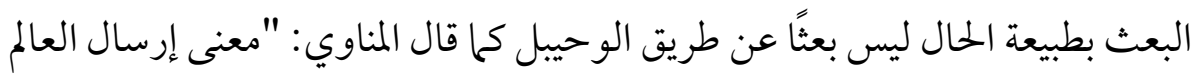

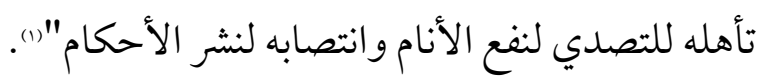

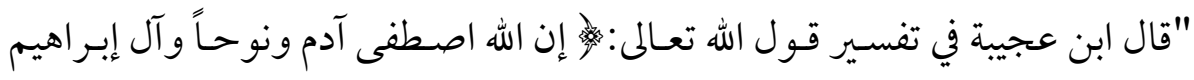

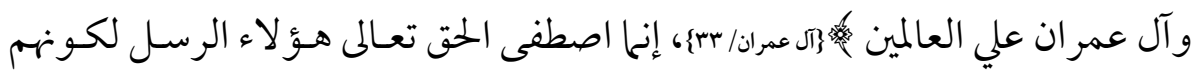

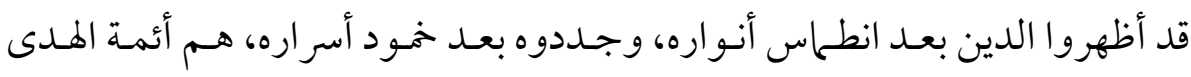

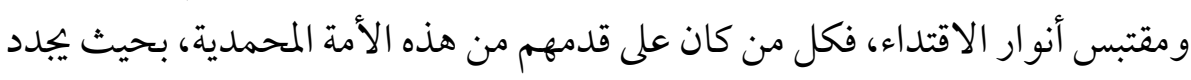

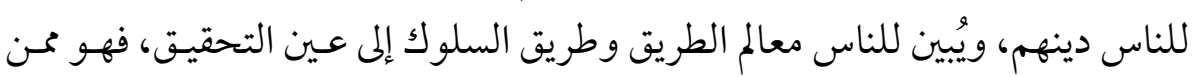
اصطفاه الله على عالمي زمانه.

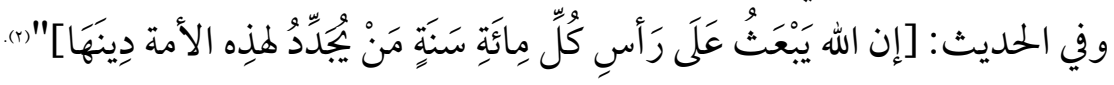

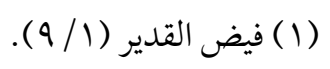

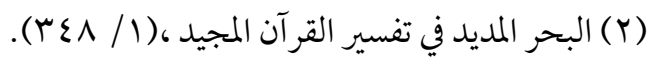


وقد حفلت السنة المشرفة بالأحاديث الدالة على مكانـة العللهاء وبخاصـة الـدعاة مـنهم والمصلحون و ف ويأتي في طليعة هذه الأحاديث:

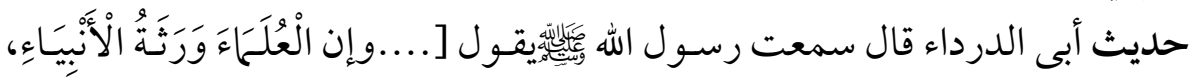

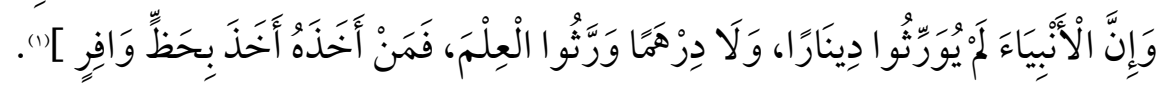

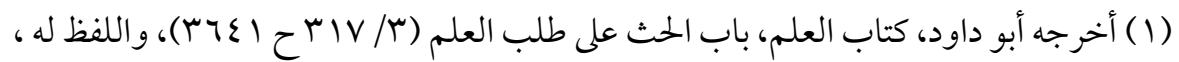

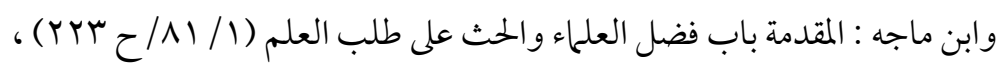

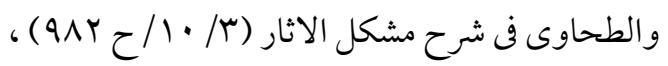

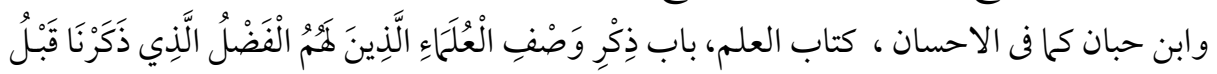

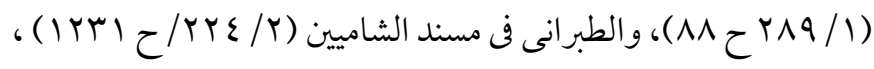

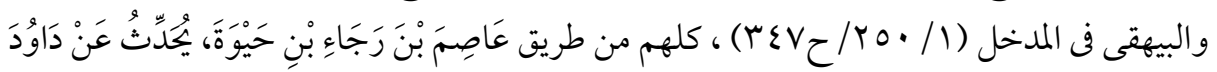

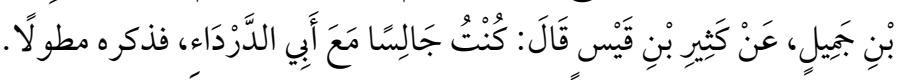

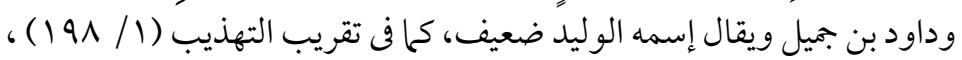

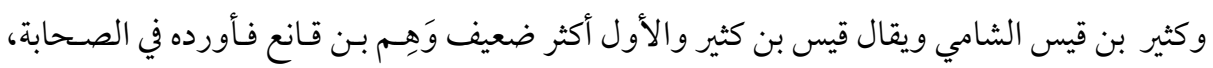

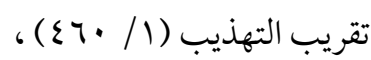

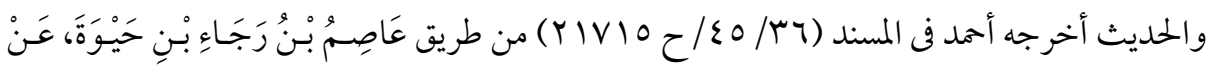

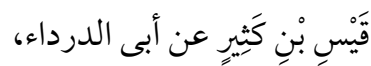

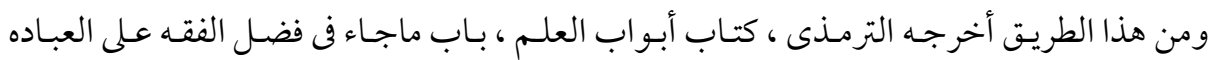

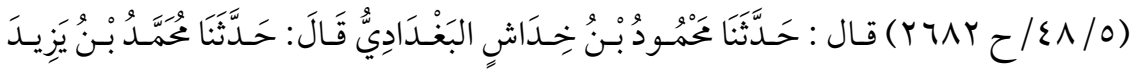

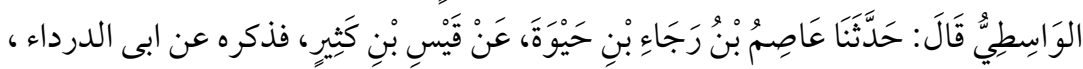

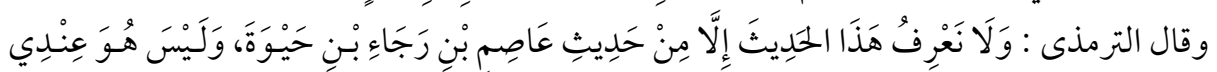

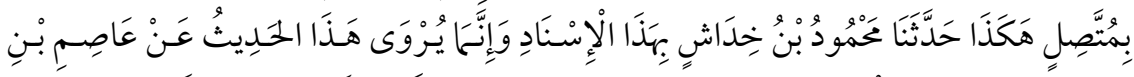

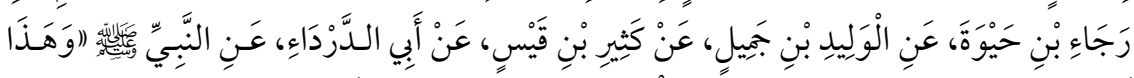

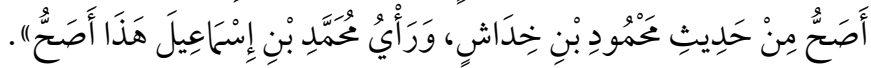

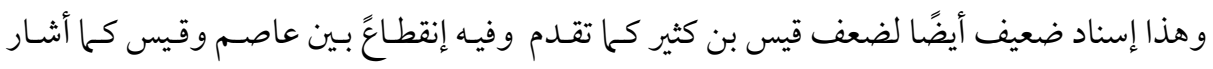
الترمذى.= 
قال ابن القيم: "هذا من أعظم المناقب لأهل الْعلم فَإِن الأنبياء خِير خلقِ الله فورثتهم

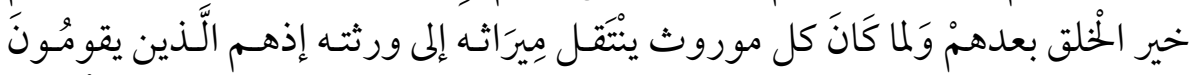

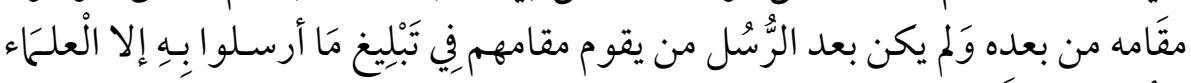

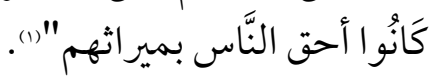

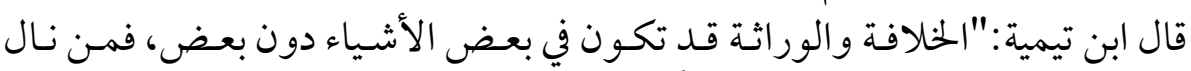

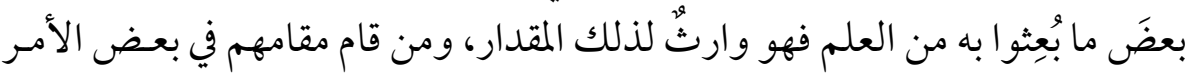

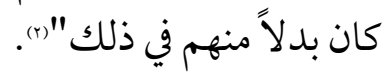

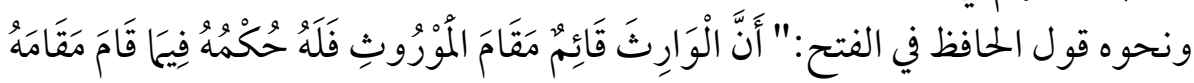
فِيدِ" (r)

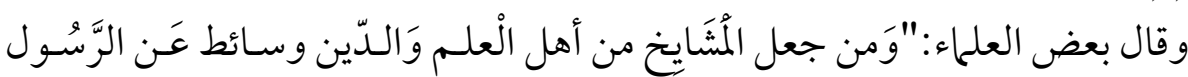

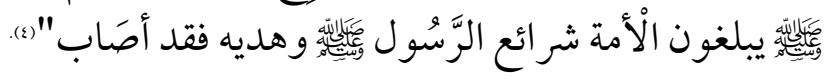

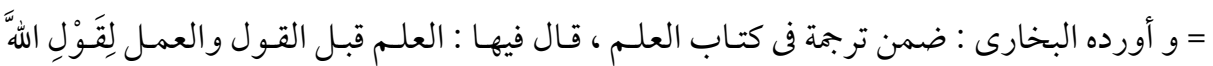

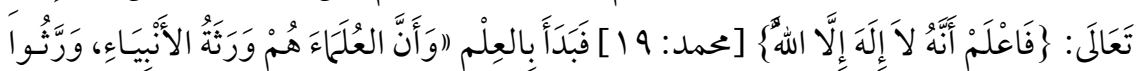

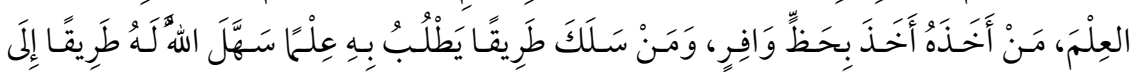
، (Y乏/1)(攵)

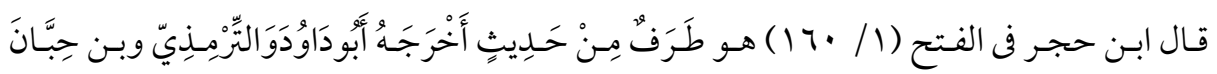

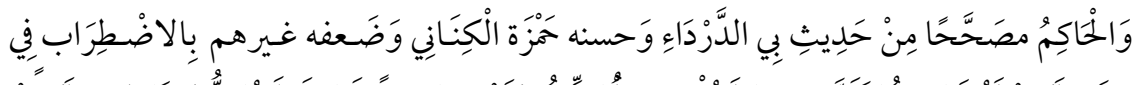

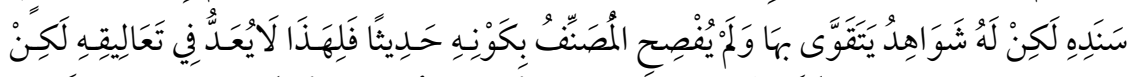

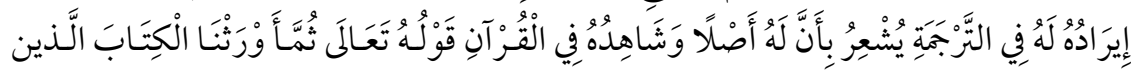

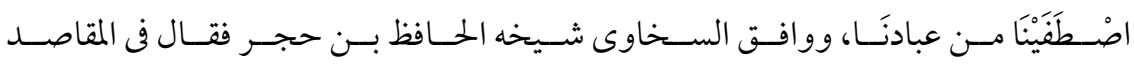

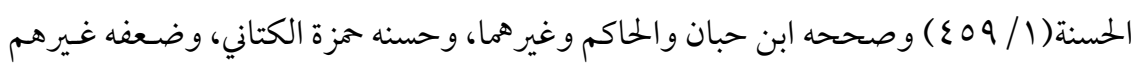

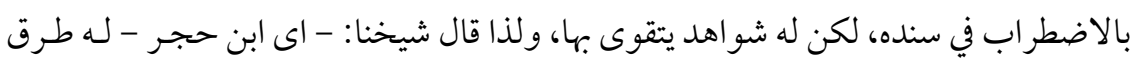

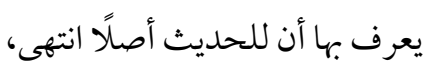

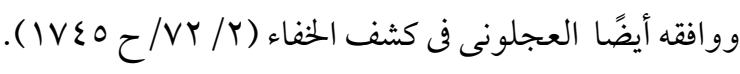

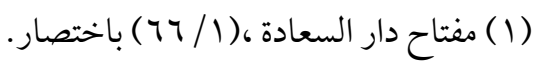
(Y)

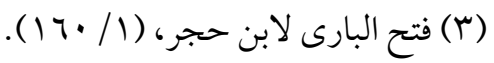

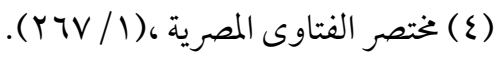




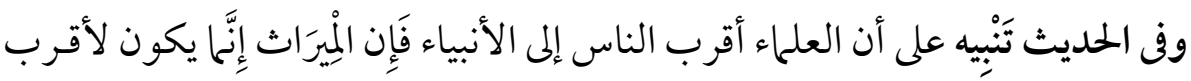

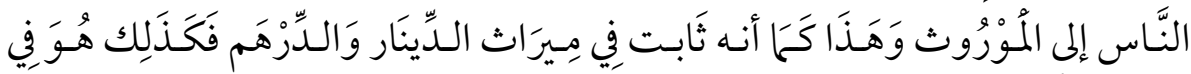

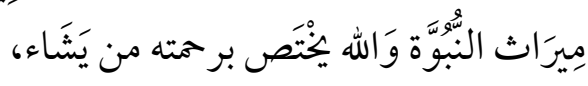

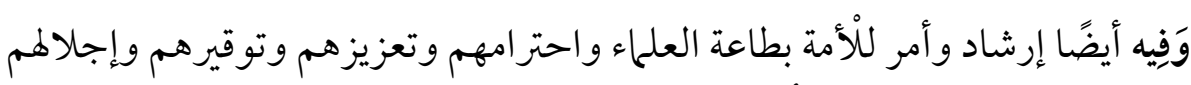

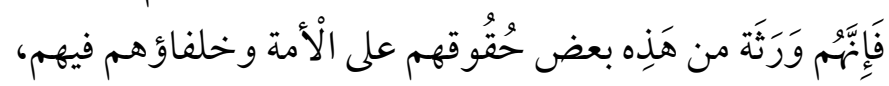

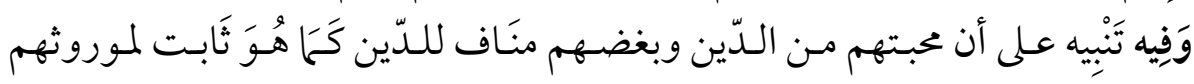

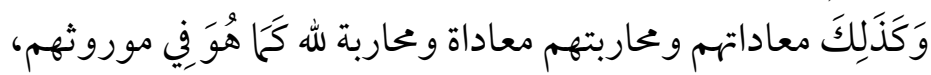

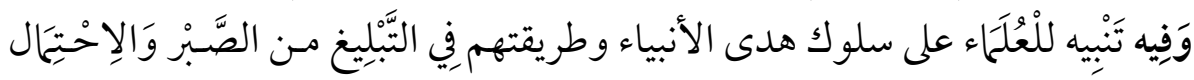

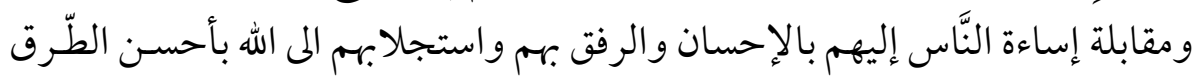

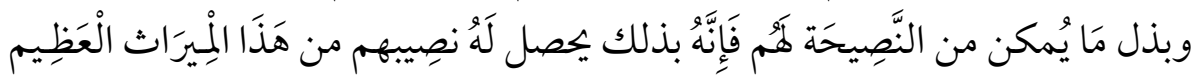

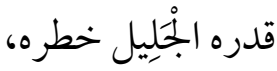

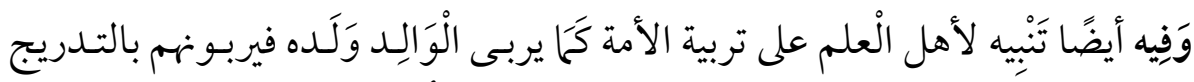

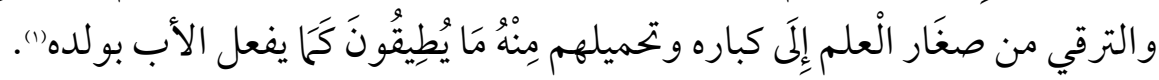

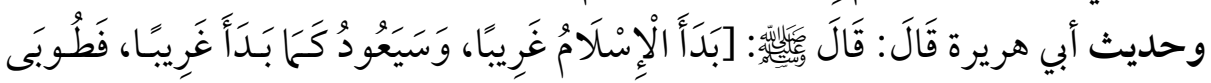

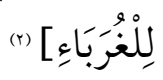

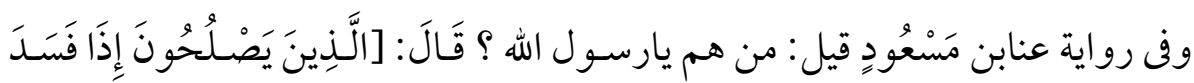

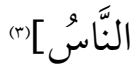

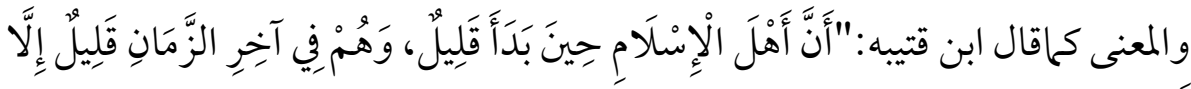
أَنَّهمن خِيَّار "(s).

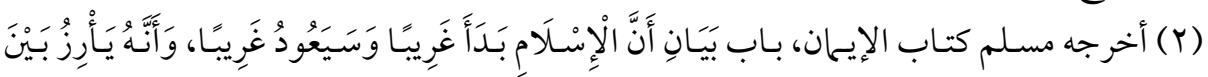

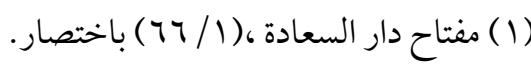

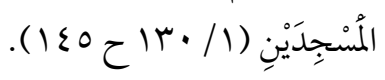

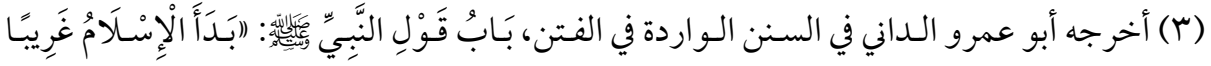

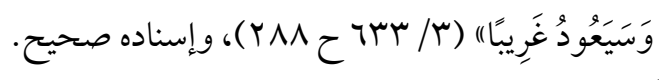

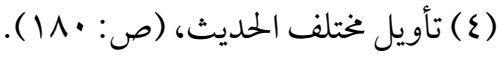


قال القاضى: "وظاهر الحديث العمومُ، وأن الإسلام بدأ في آحاد من الناس وقلَّةٍ ثمان

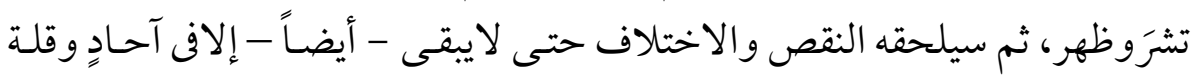

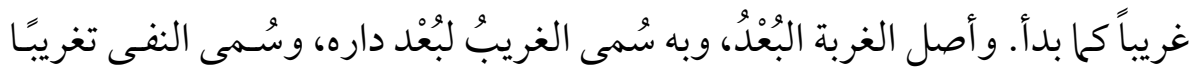

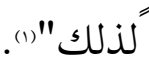

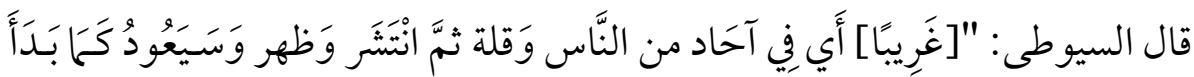

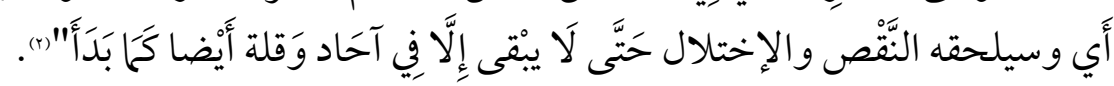

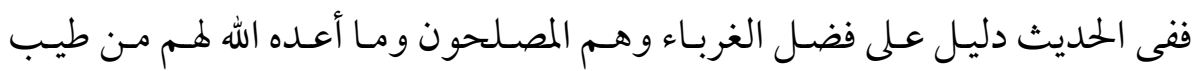

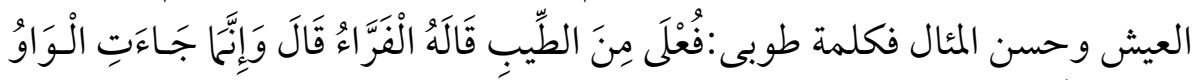

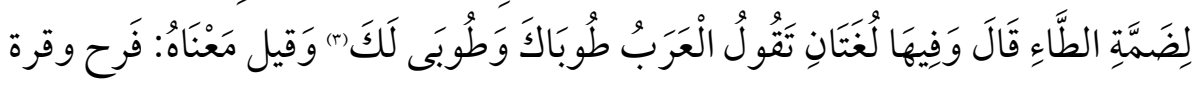

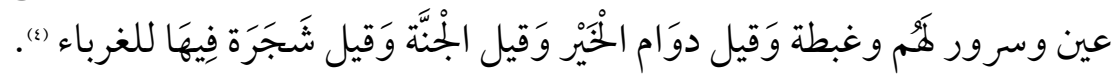

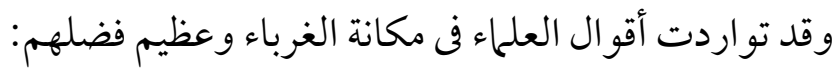

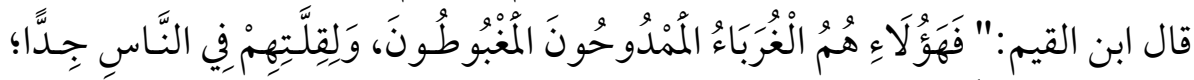

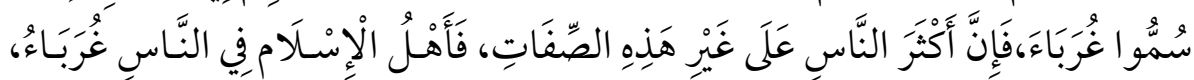

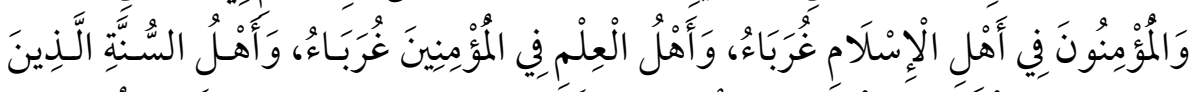

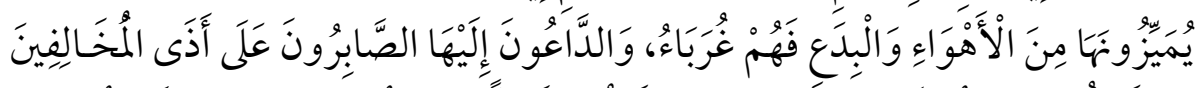

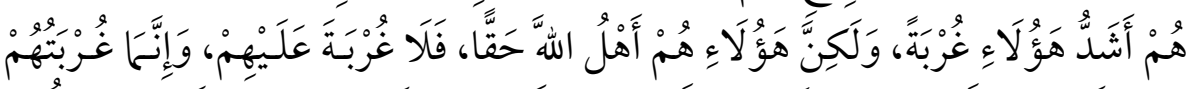

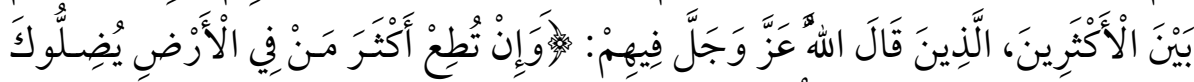

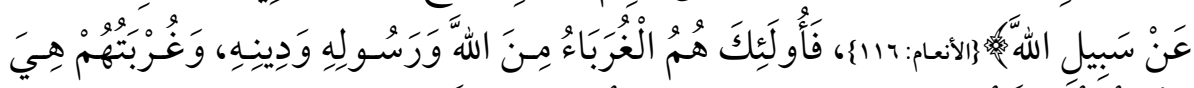

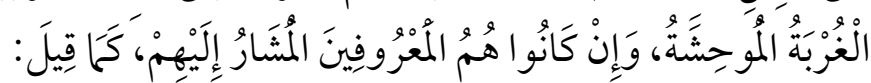

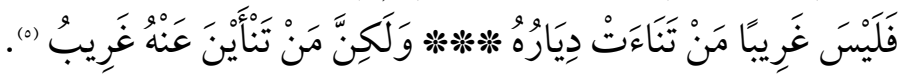

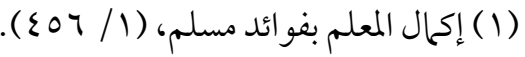

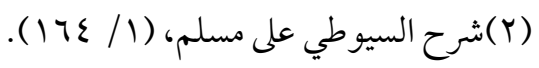

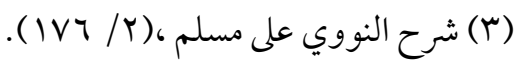

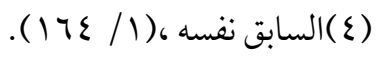

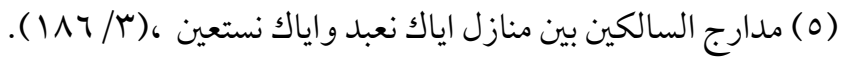




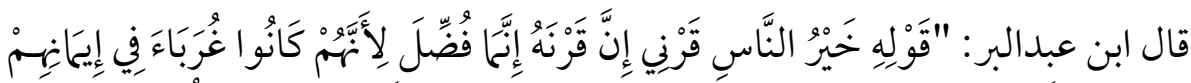

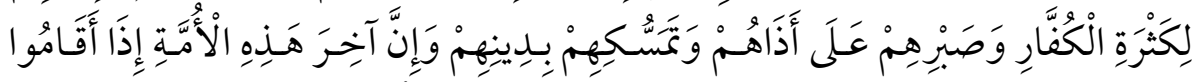

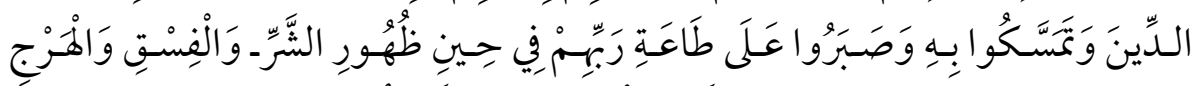

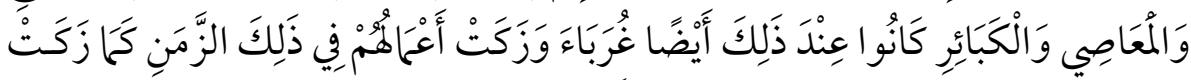

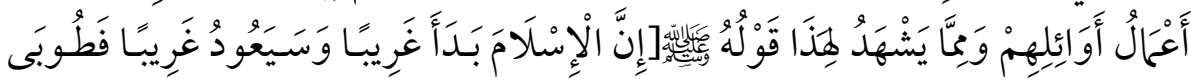

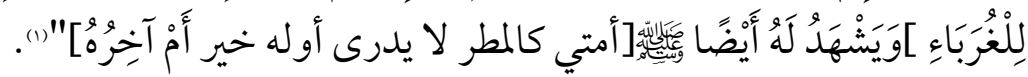

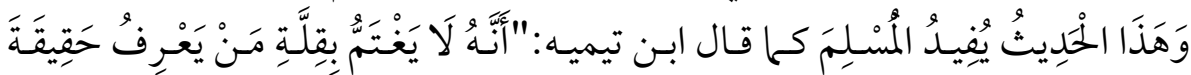

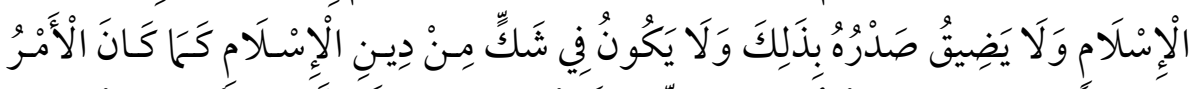

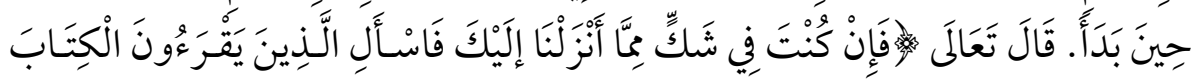

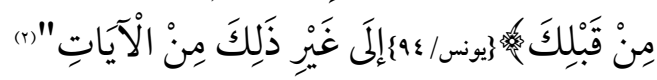

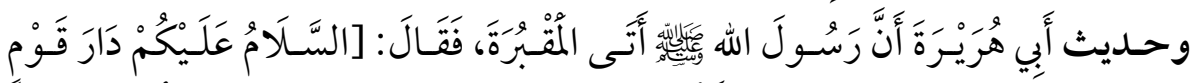

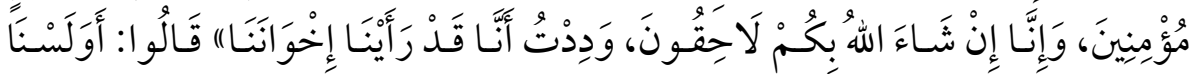

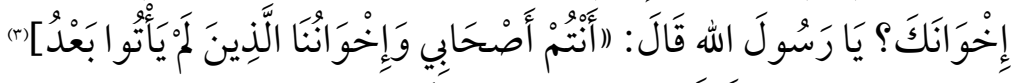

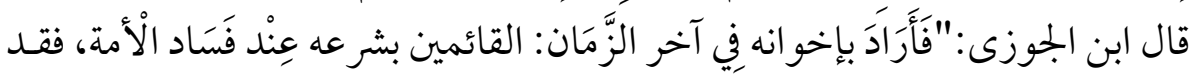

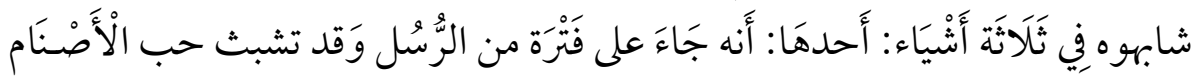

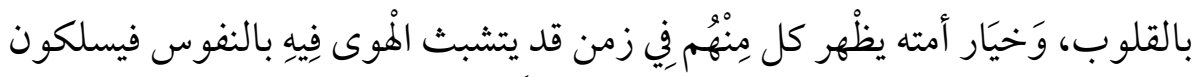

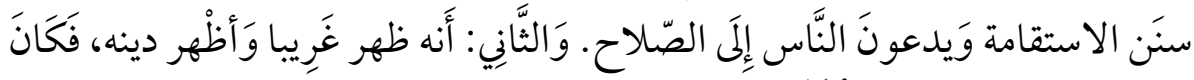

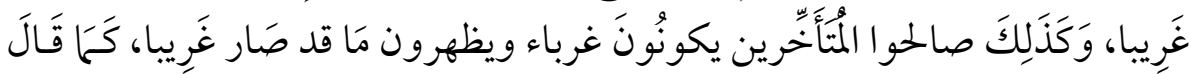

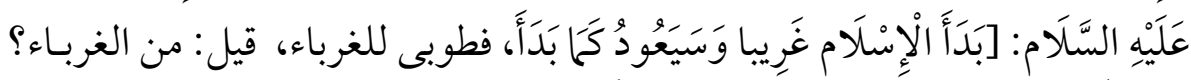

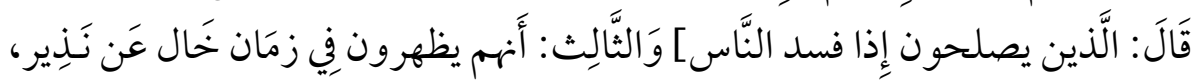

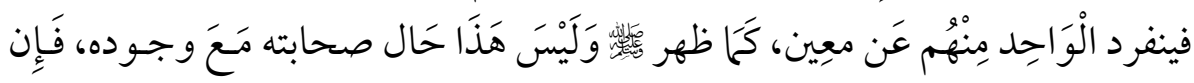

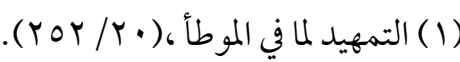

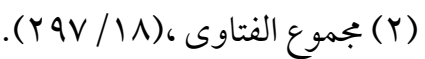

(Y) أخرجه مسلم وسبق تخريهه وشر حه بآتم مما هاهنا في المبحث الثالث.

$0 \leqslant 1$ 


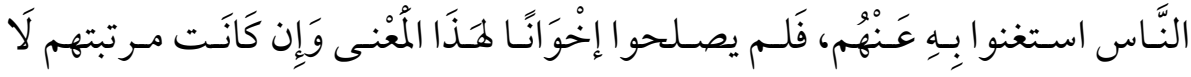

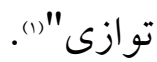

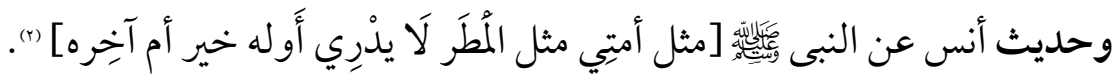

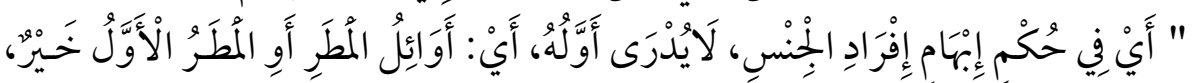

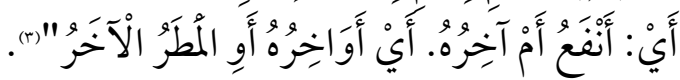

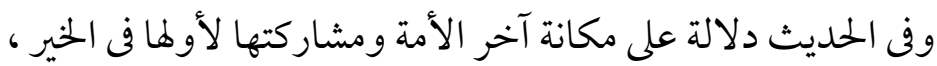

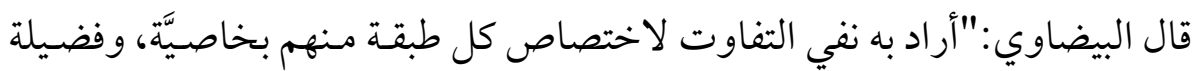

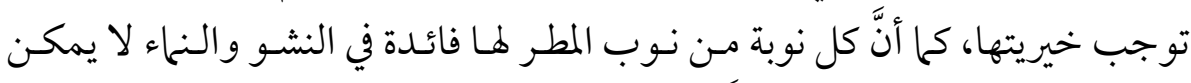

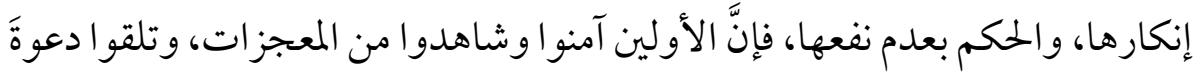

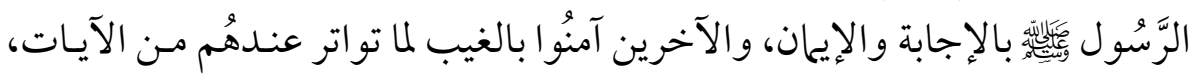

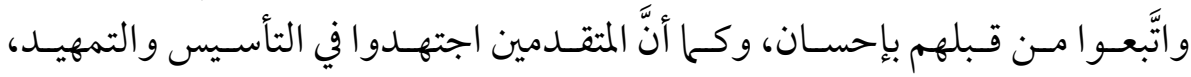

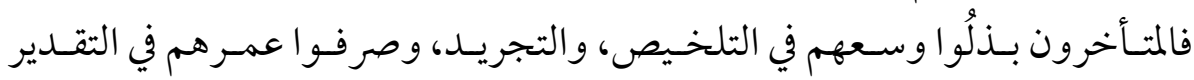

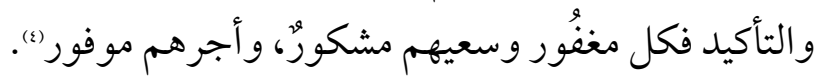

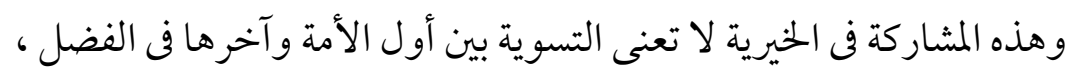

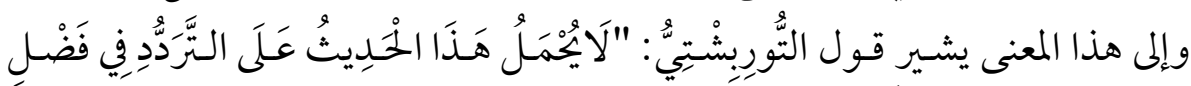

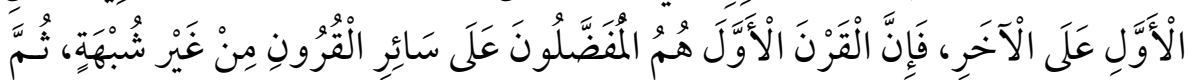

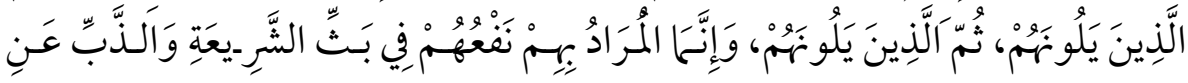

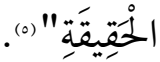

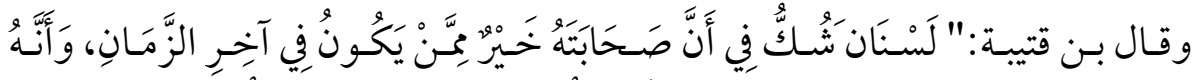

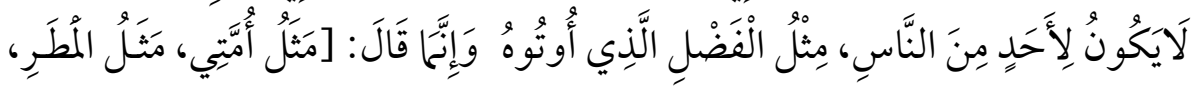

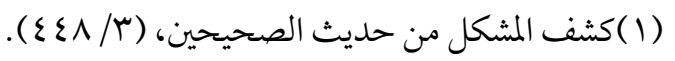

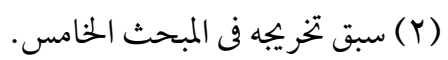

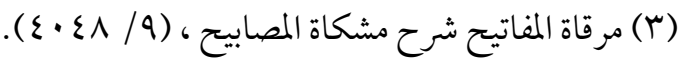

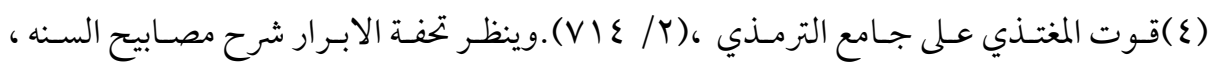
. (O^ $\varepsilon / \mu)$

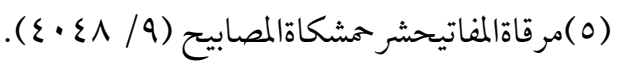




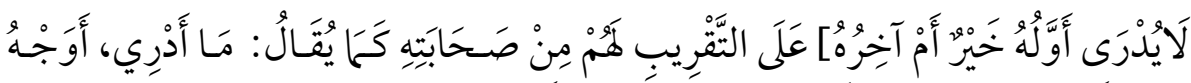

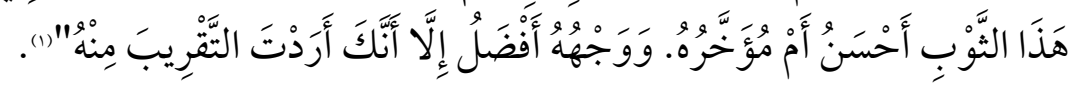

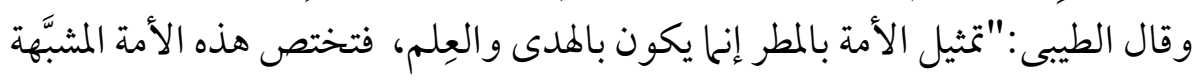

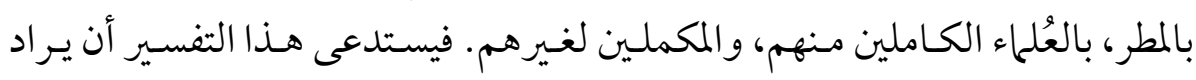

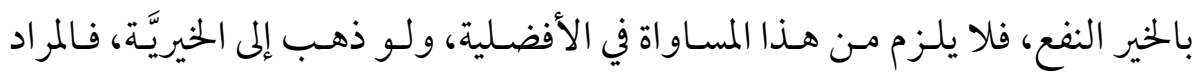

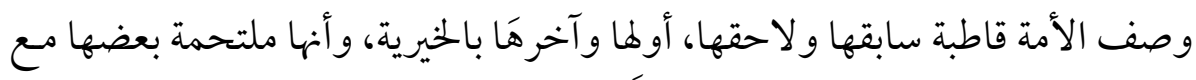

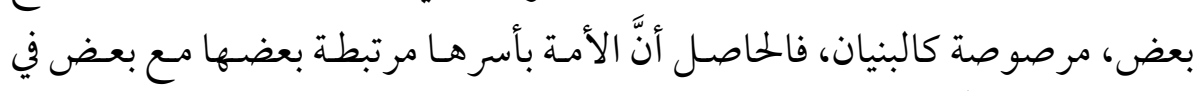

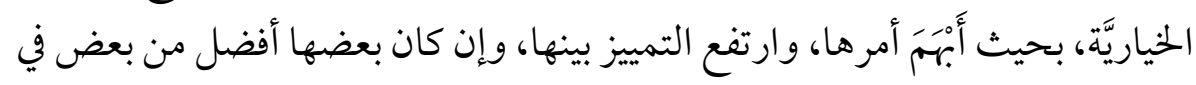

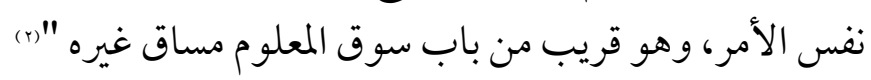

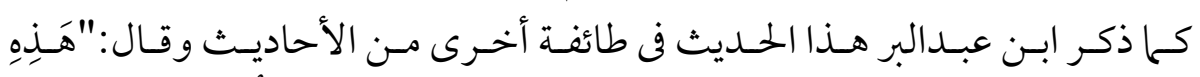

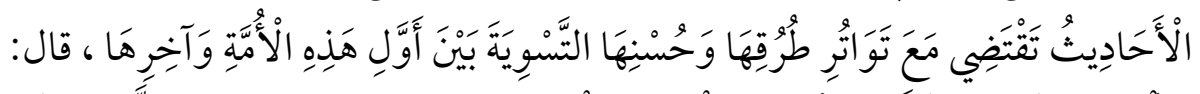

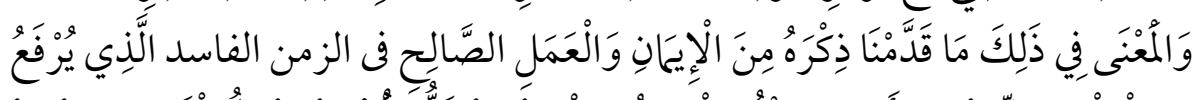

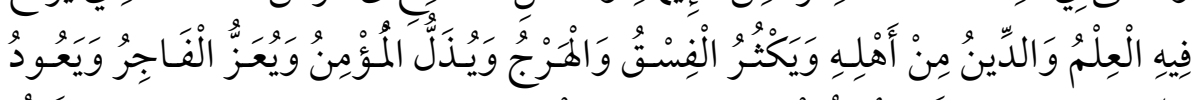

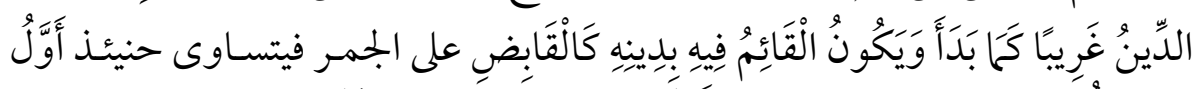

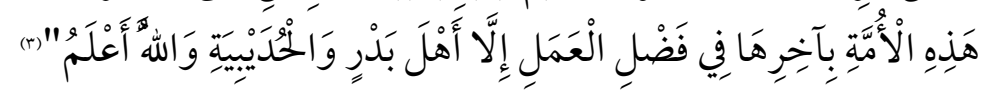

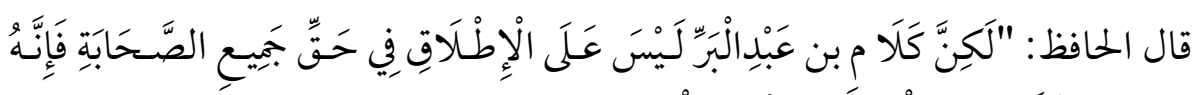

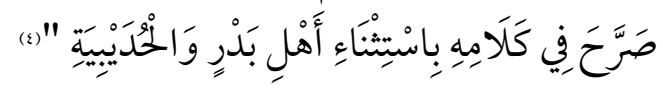

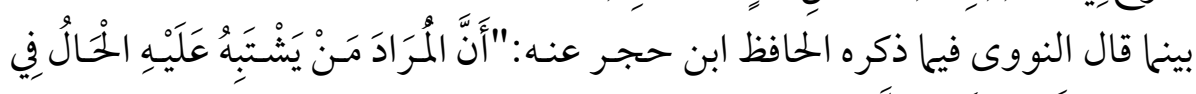

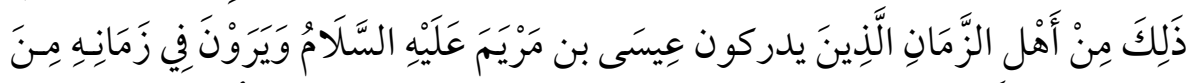

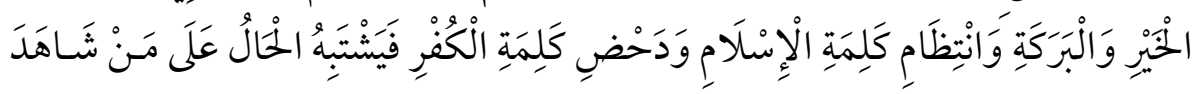

(1) تأويل غختلف الحديث، (ص: (1) (1) ).

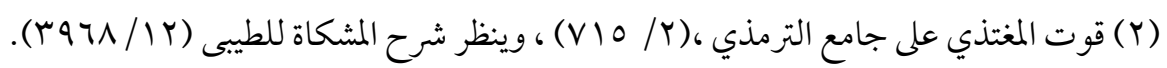

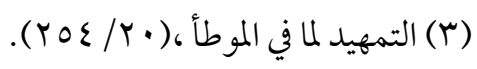

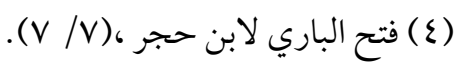

00. 


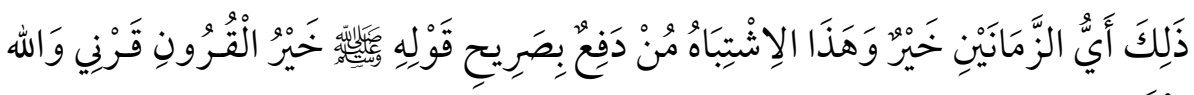

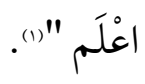

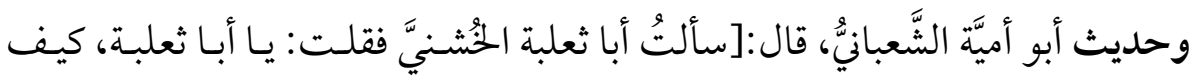

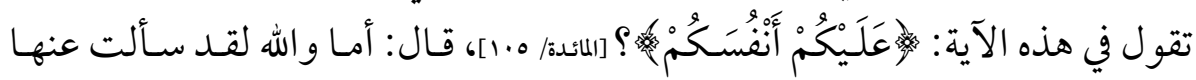

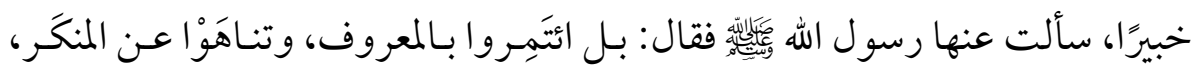

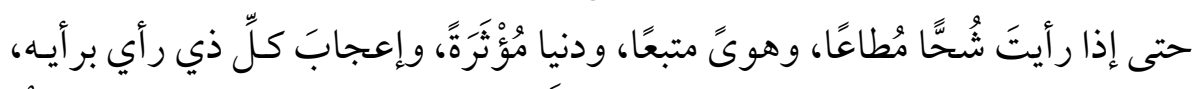

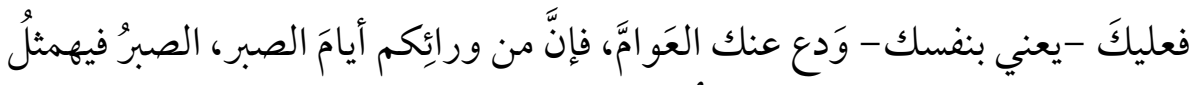

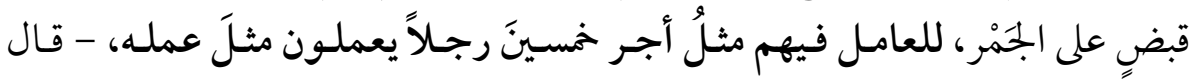

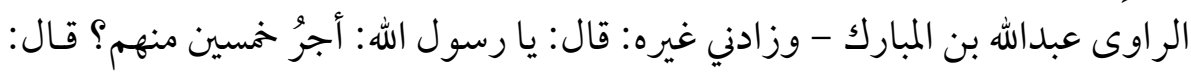

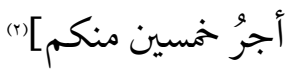

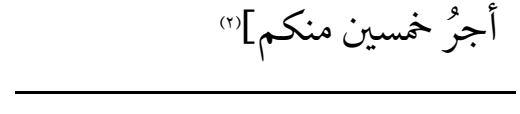

(1) السابق نفسه، (Y/V) ( (1).

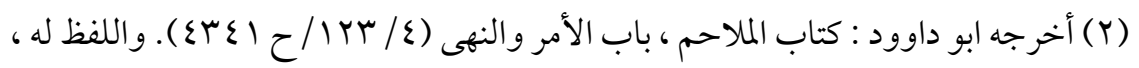

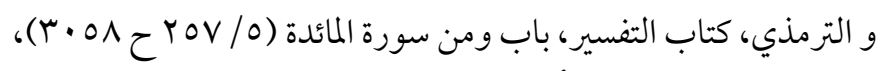

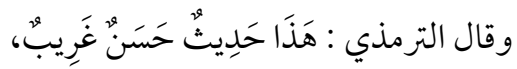

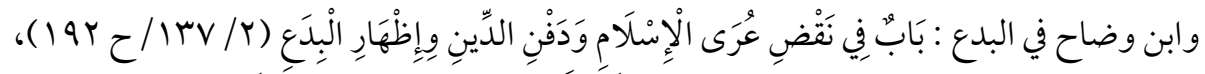

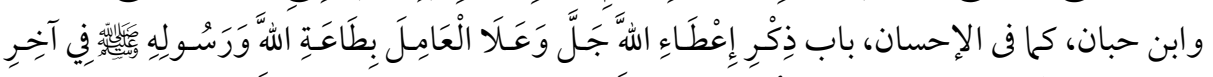

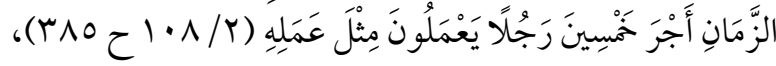

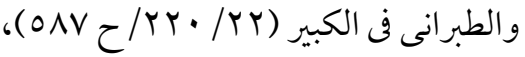

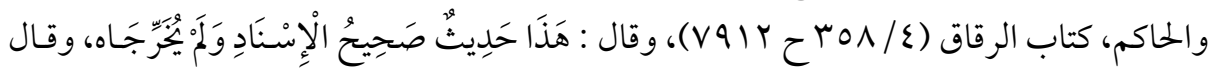

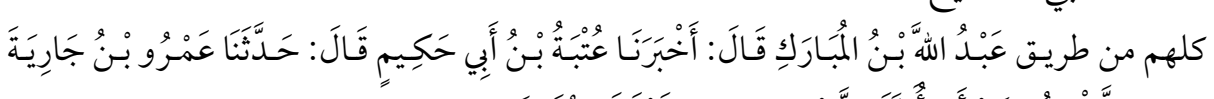

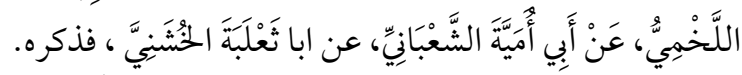

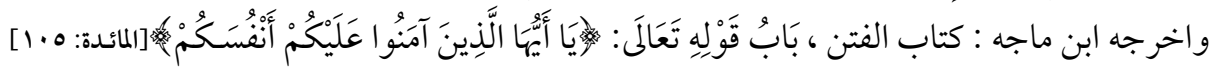

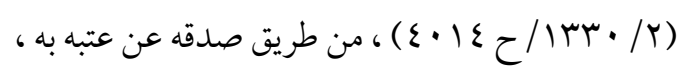

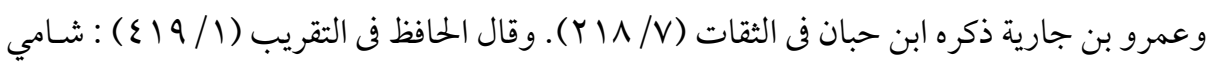

$$
\text { مقبول من السابعة.= }
$$




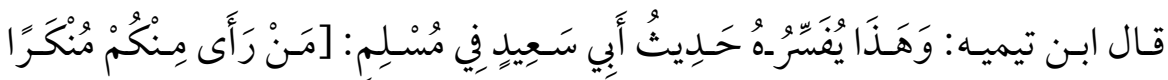

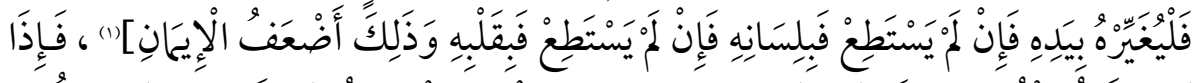

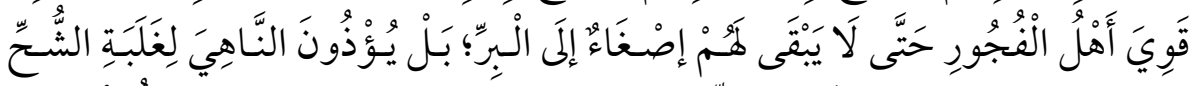

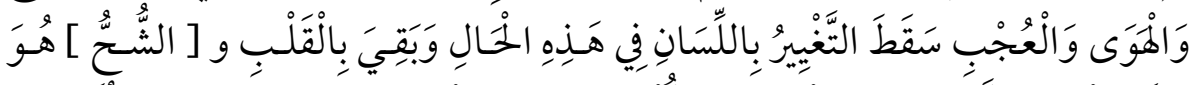

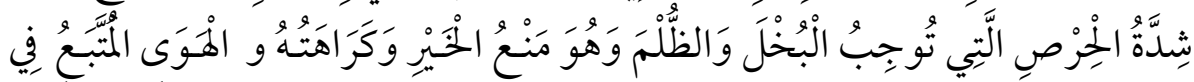

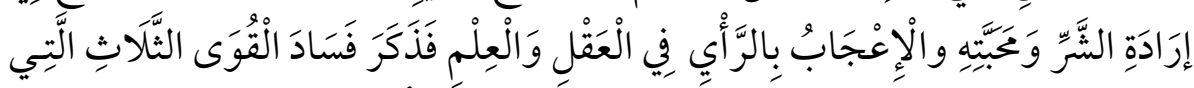

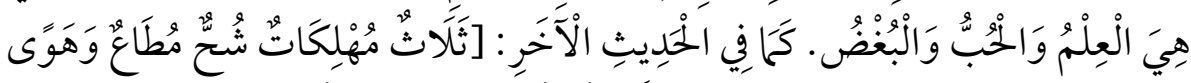

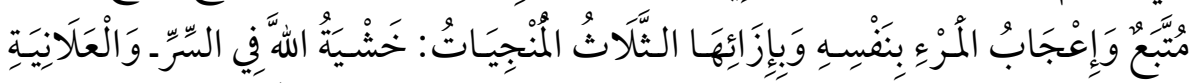

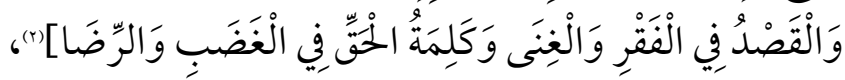

= قلت وإن كان الحديث فى إسناده ضعف إلا أن جزئه الأول يتقوى بحديث أنس الآتى ذكره أنظر

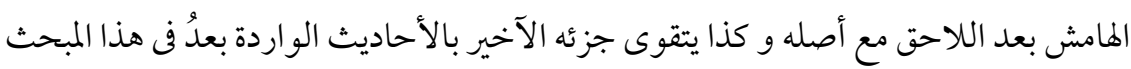

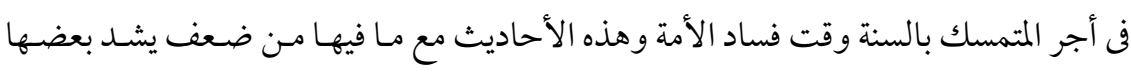

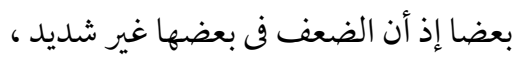

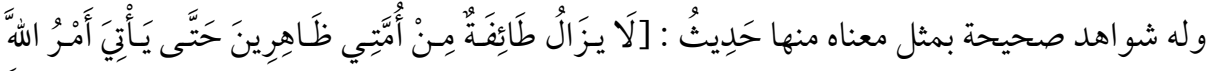

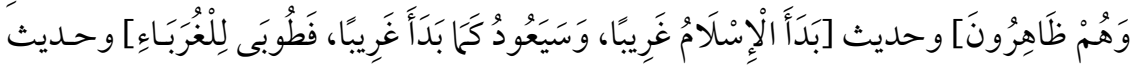

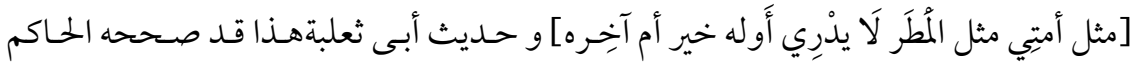

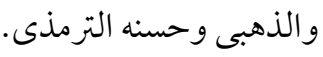

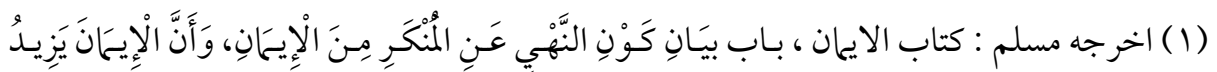

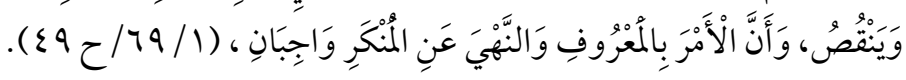

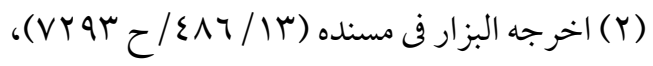

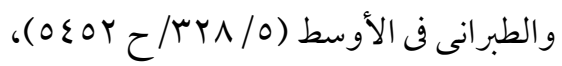

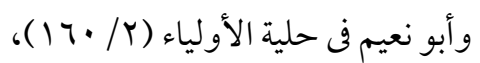

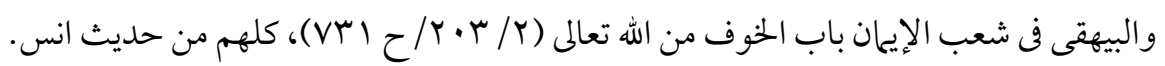

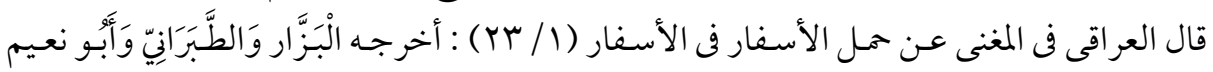

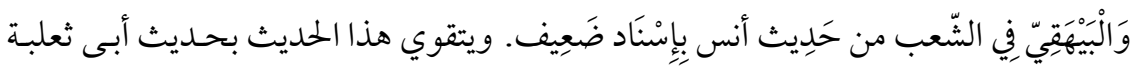
الخشنى السابق وبحديث عمار الأتى. ولئ. 


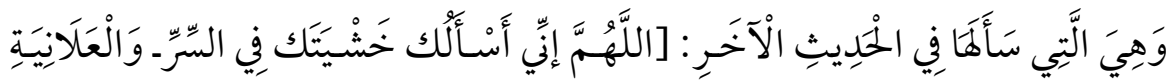

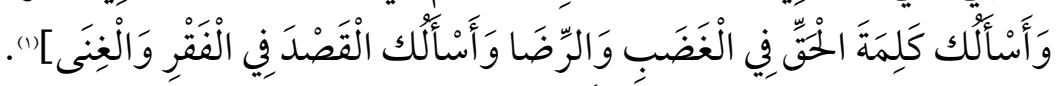

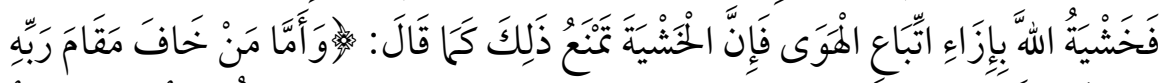

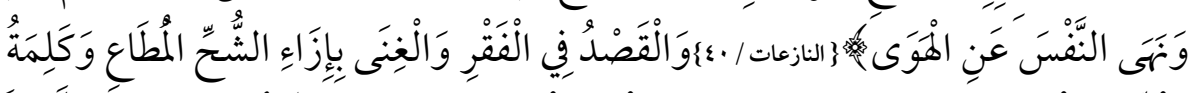

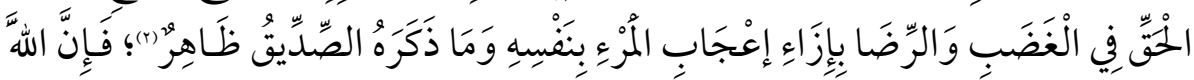

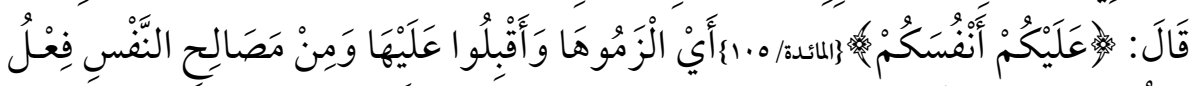

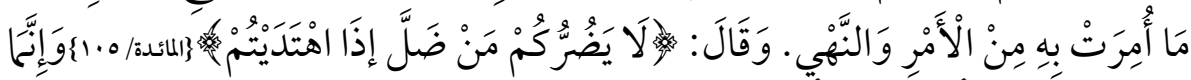

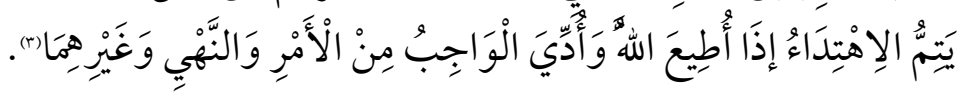

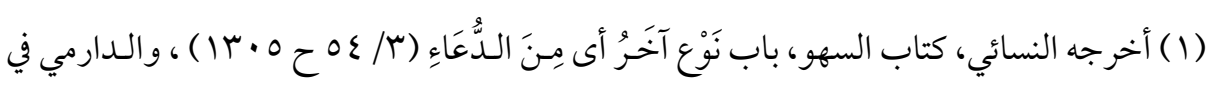

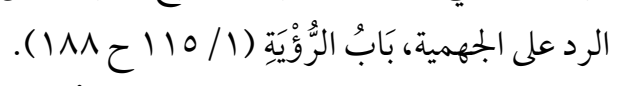

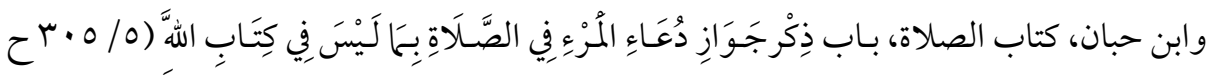

(19V)

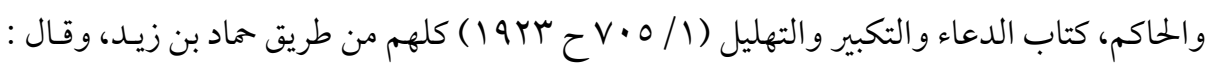

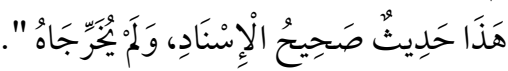

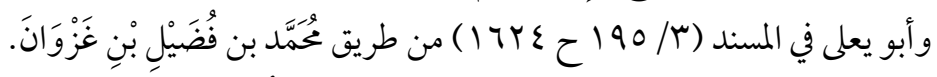

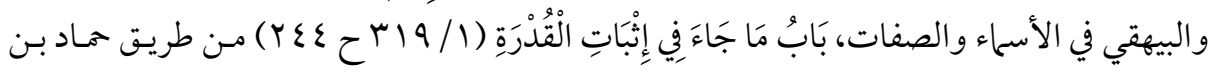

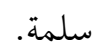

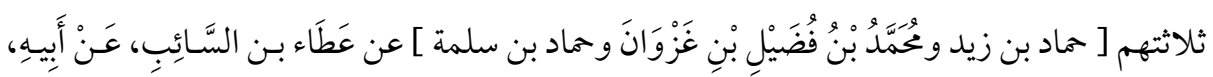

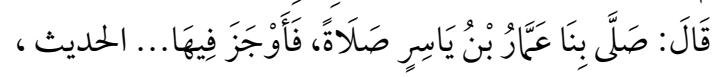

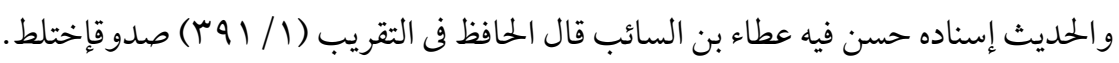

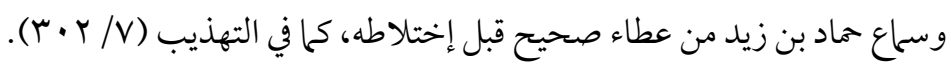

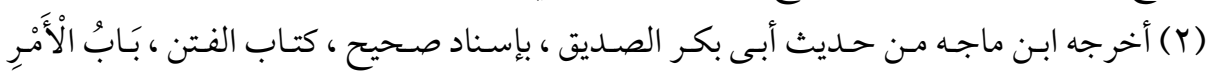

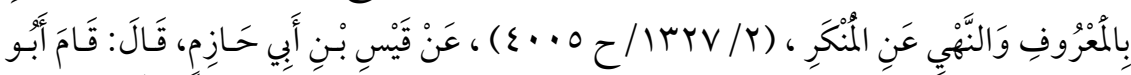

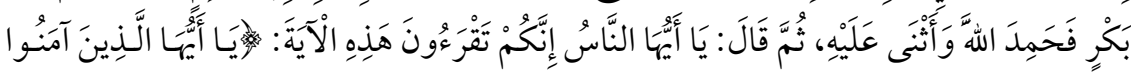

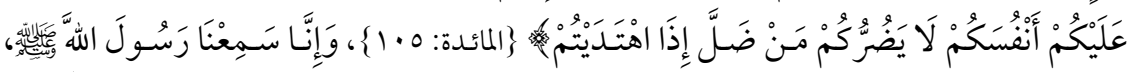

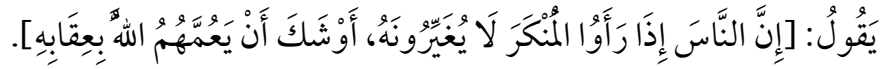

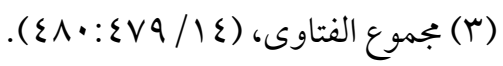




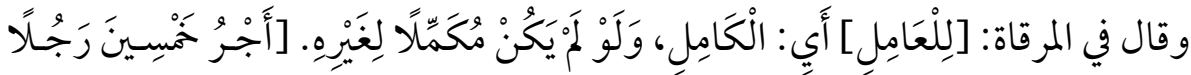

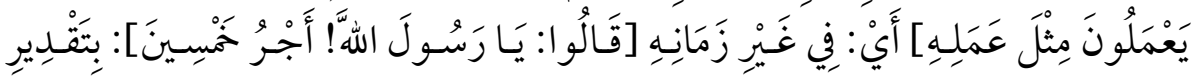

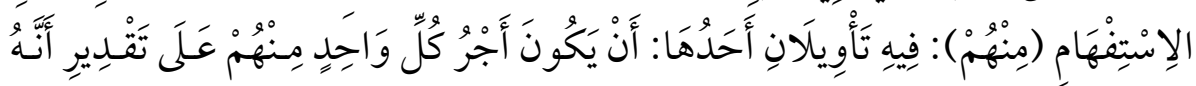

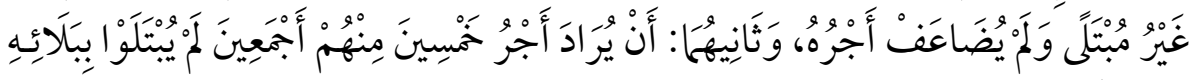

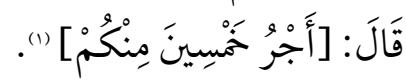

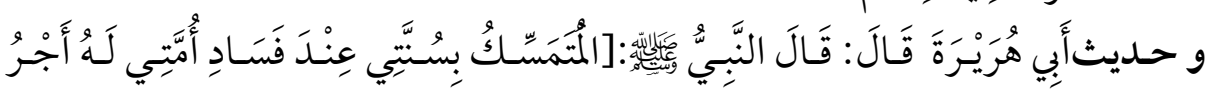
شَهِيدٍِ قال المباركفوري:"قوله: [ [عند فساد أمتي] أي عند غلبة البدعة والجهل و الفسق فيهمه،

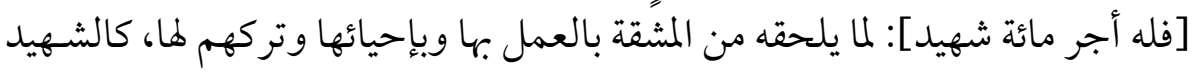

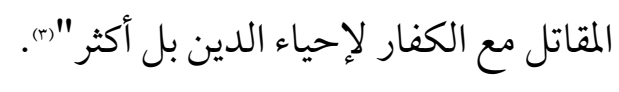

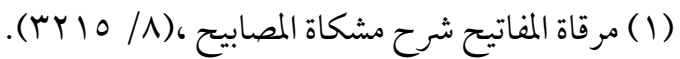

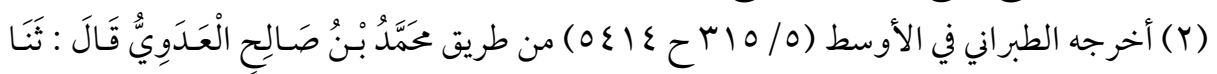

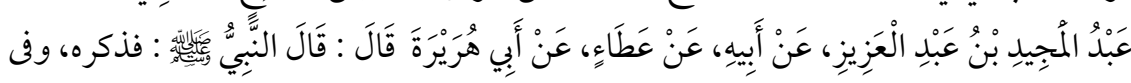

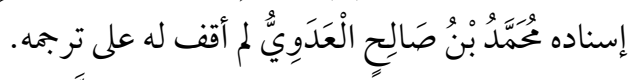

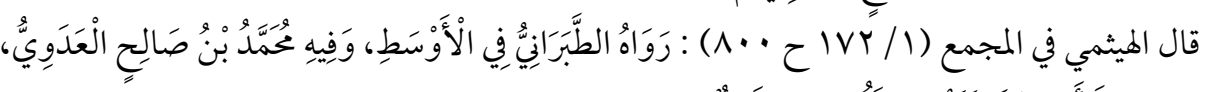

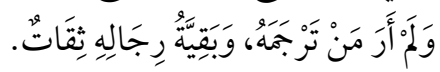

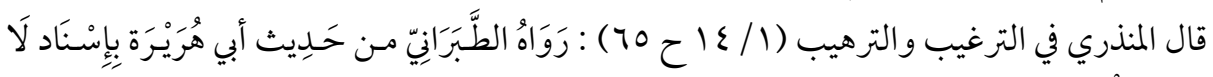
بَأْس بِِ.

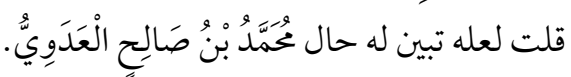

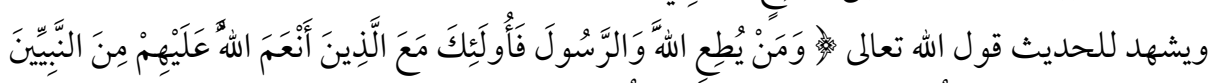

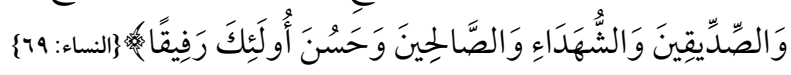

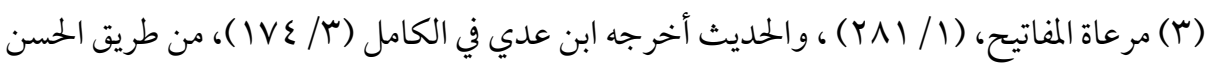

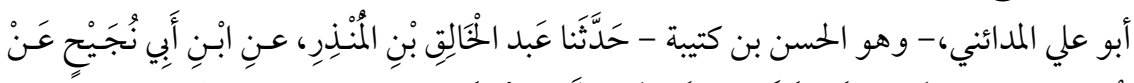

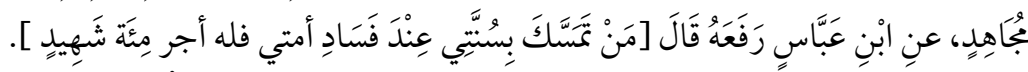

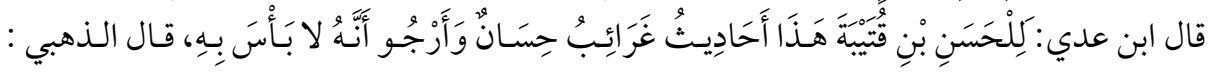

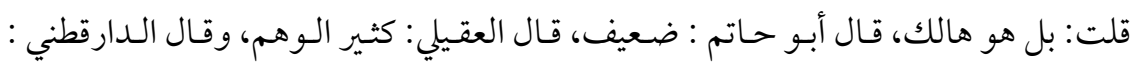

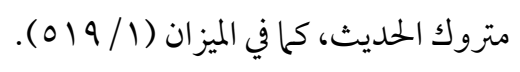


و قال الطيبي:"قيل [فساد أمتى] ولم يقل: إفسادهم لأنهابٔلغ، كأن ذواتهم قد فسـدات

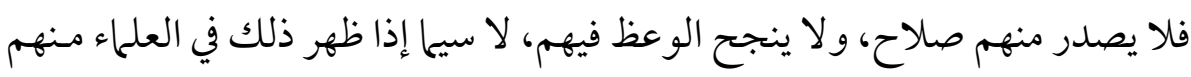

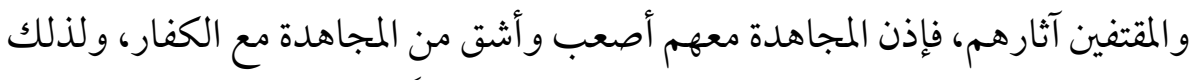

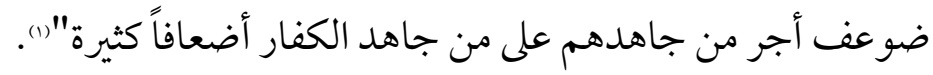

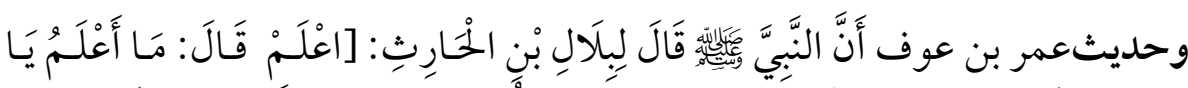

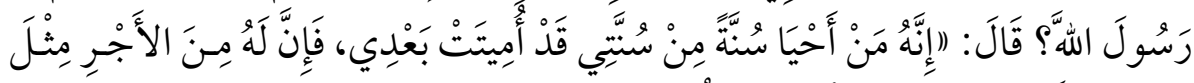

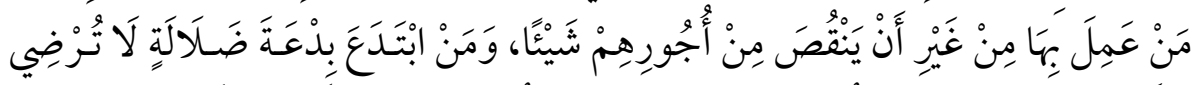

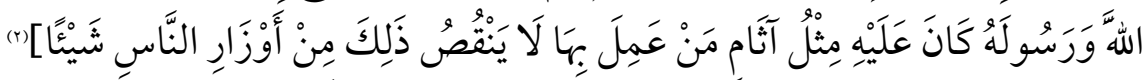

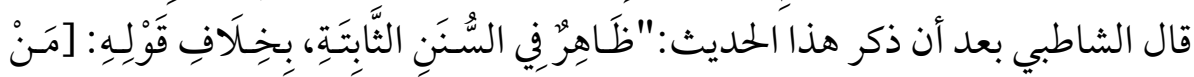

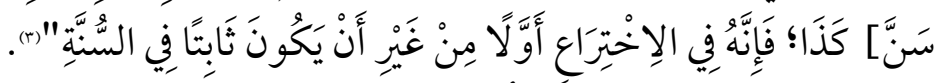

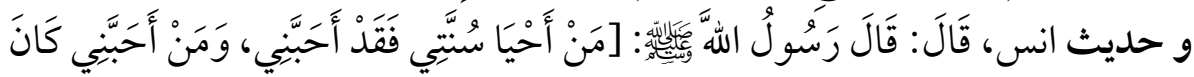

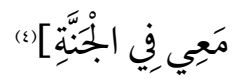
قال صاحب التنوير :"[من أحيا سنتي] بالعمل بها و إثاعتها ونفي تحريف المحرفين لها

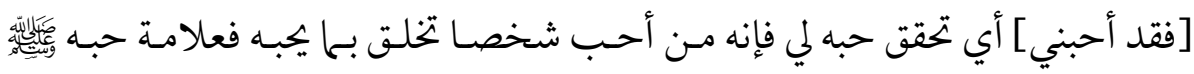

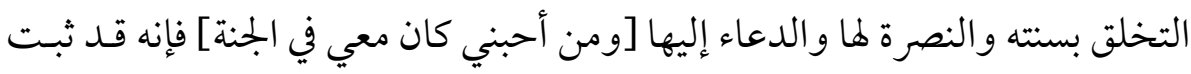

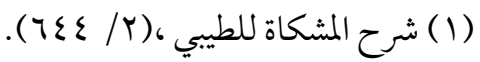

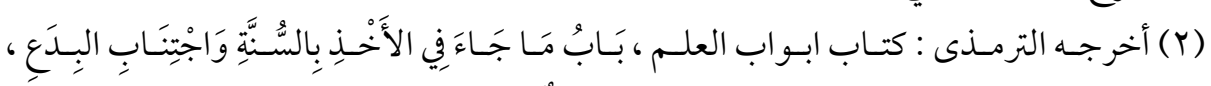

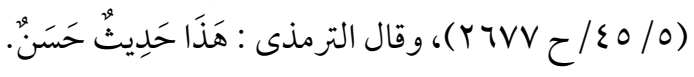

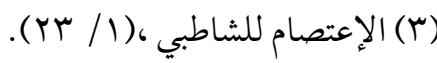

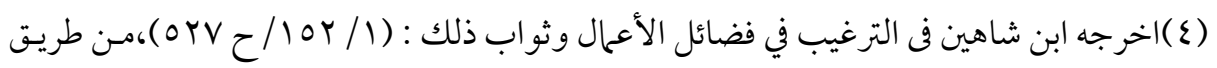

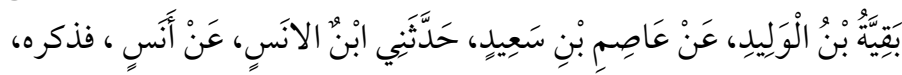

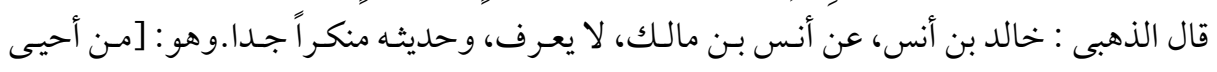

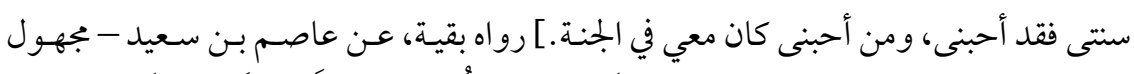

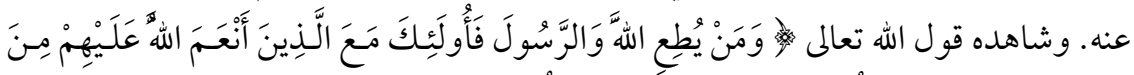

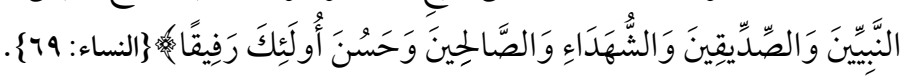




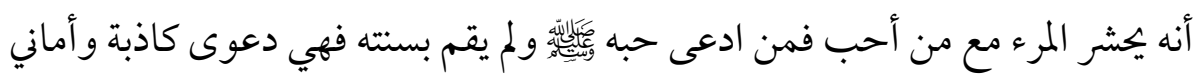
باطلة" (1). بكتر

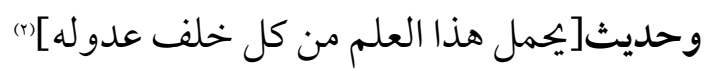

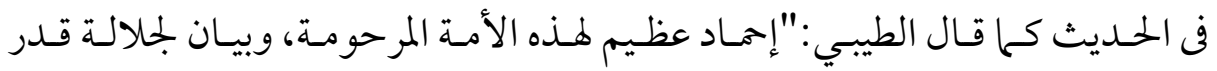

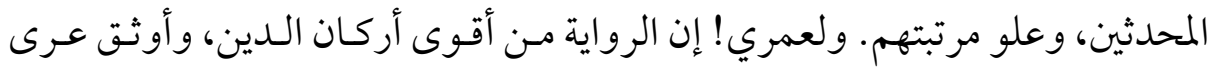

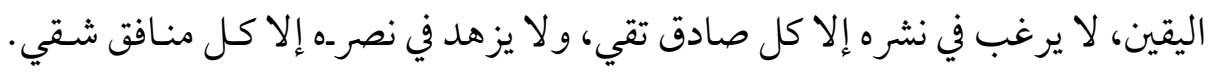

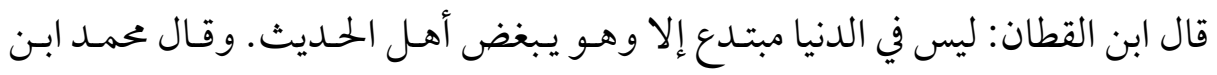

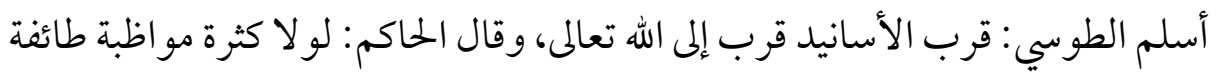

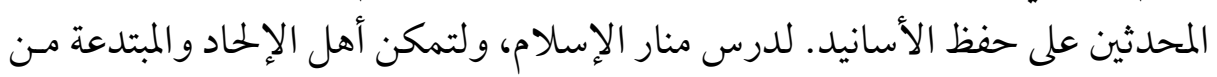

$$
\text { وضع الأحاديث، وقلب الأسانيد" (r). }
$$

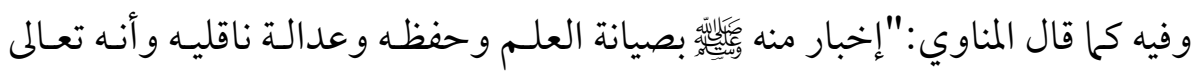

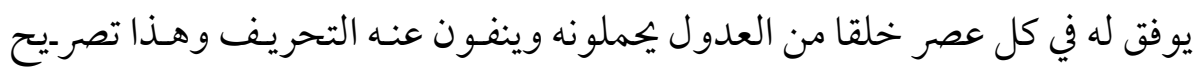

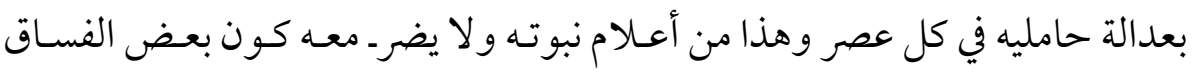

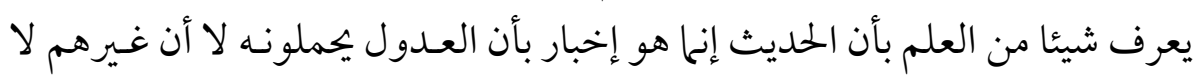

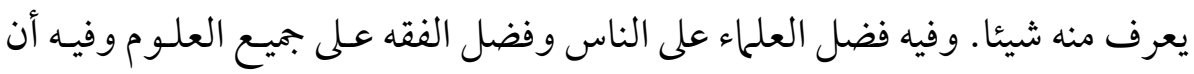
هذه الأمة آخر الأمم و أنه لا بد أن يبقى منها من يقوم بأوامر الله حتى يأتي أمر الله" ل(ع).

$$
\text { ومن الآثار الموقوفه: - م الم }
$$

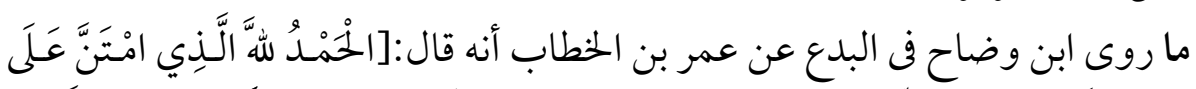

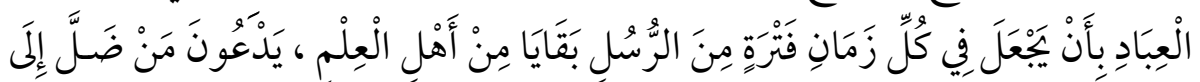

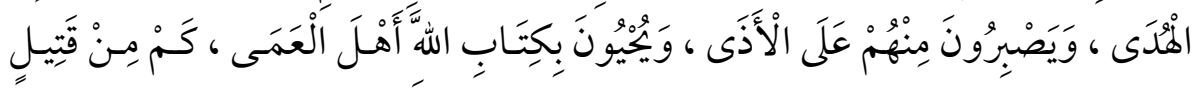

$$
\begin{aligned}
& \text { (1) التنوير شرح الجامع الصغير، ( (1/ 00). } \\
& \text { (Y) سبق تخريجه فى المبحث الخامس. }
\end{aligned}
$$

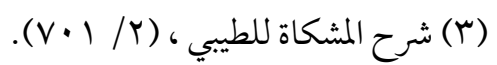

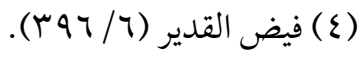




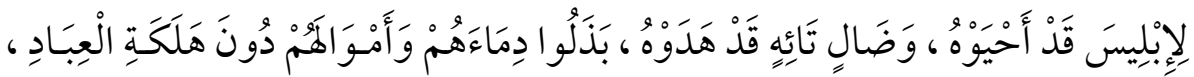

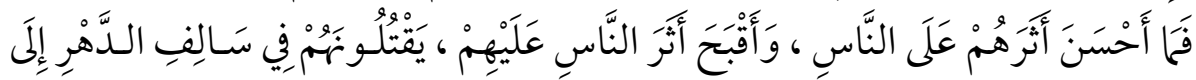

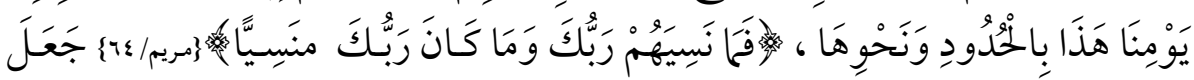

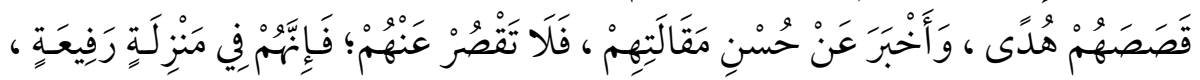

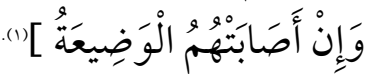

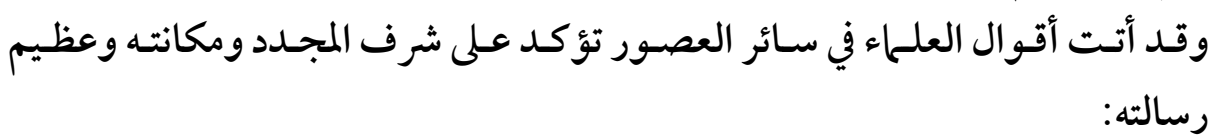

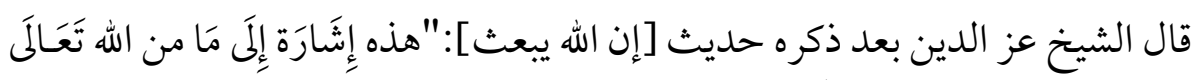

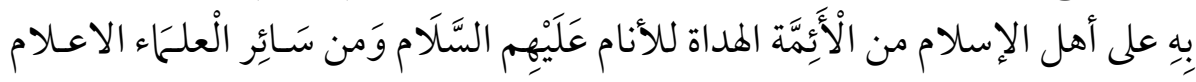

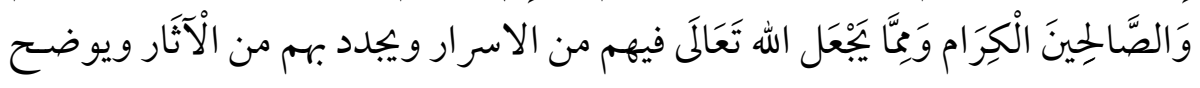

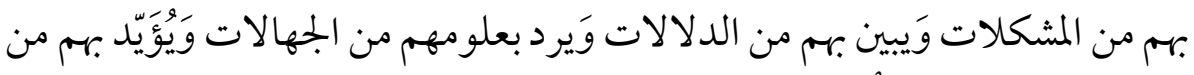

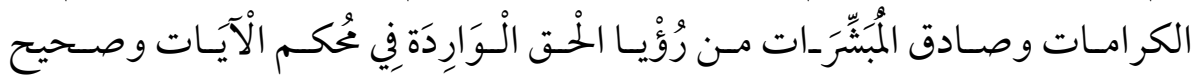

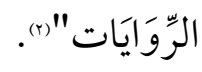

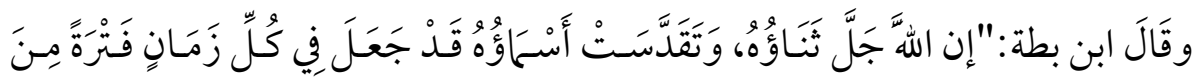

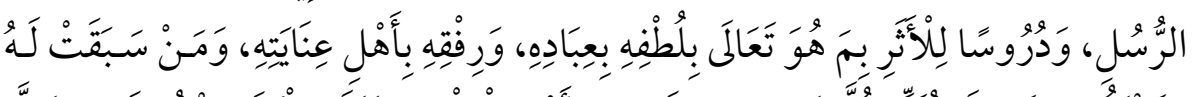

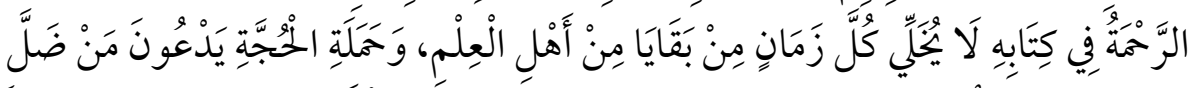

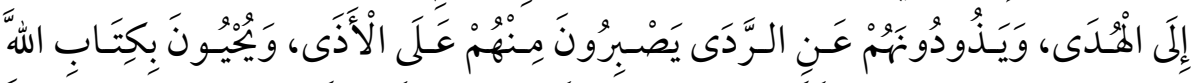

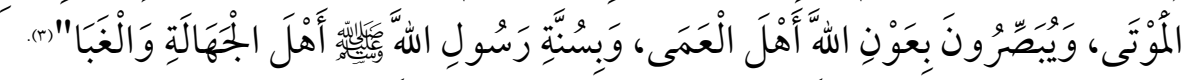

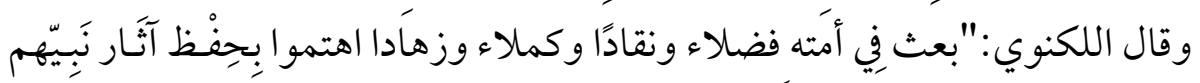

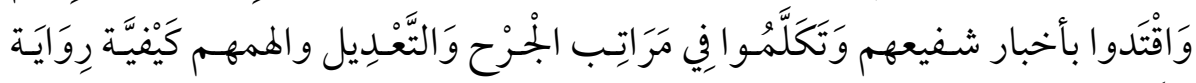

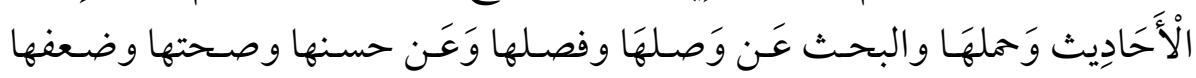

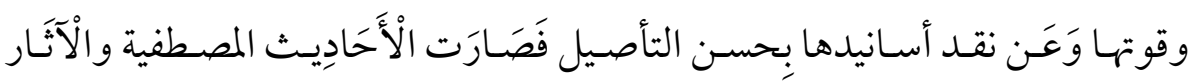

$$
\begin{aligned}
& \text { (1) الآثر سبق تخريه في المبحث الثالث. }
\end{aligned}
$$

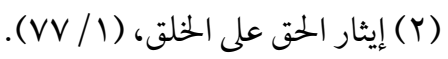

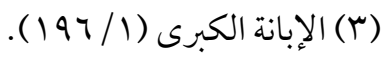




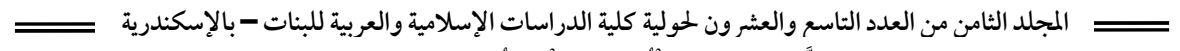

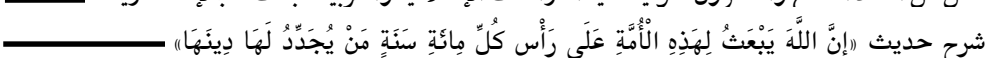

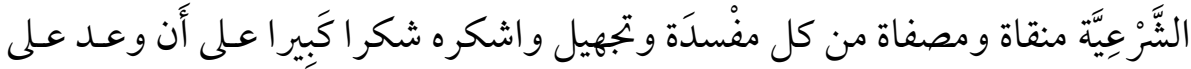

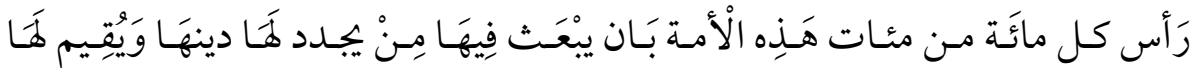

طريقتها" (1) مان

(1) الرفع والتكميل فى الجرح و التعديل، (1/ ع ع ).

$=$ 00 人 


$$
\begin{aligned}
& \text { المبحث الحادي عشر } \\
& \text { هل يكون المجدد فردًا واحدًا فى العصر أم أكثر؟ }
\end{aligned}
$$

اختلف العلماء في ذلك على قولين: القول الأول:أن المجدد لا يكون إلا فردًا واحدًا في العصر.

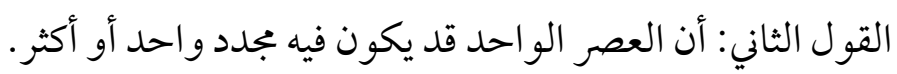

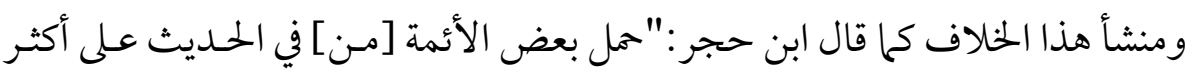

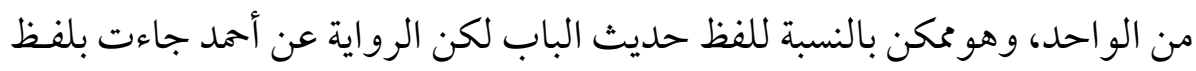

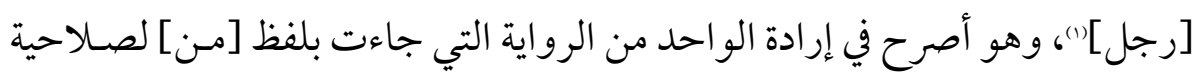

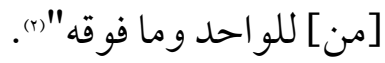

وقد مال السيوطي إلى اختيار القـول الأول وهـو أن المجـدد يكـون واحسدًا في العصر.

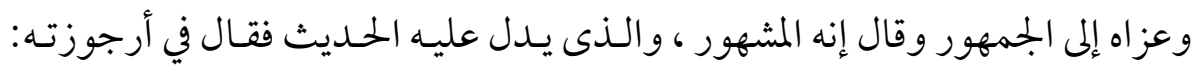

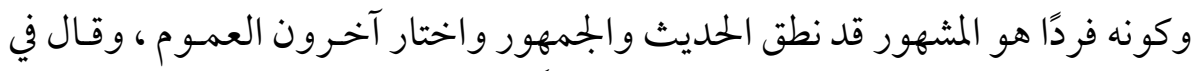

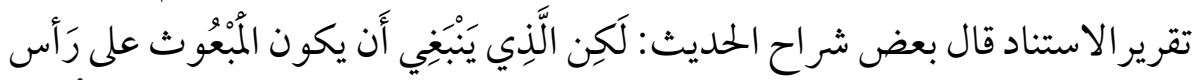

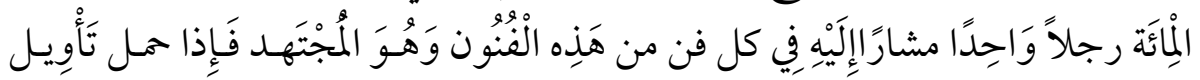

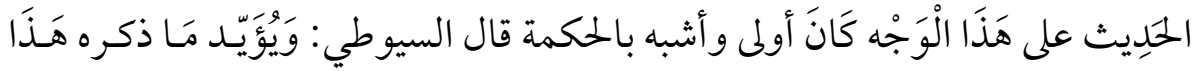

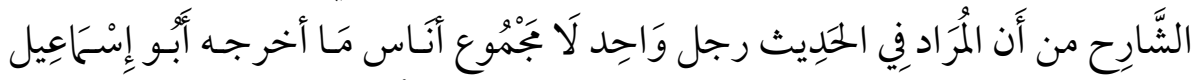

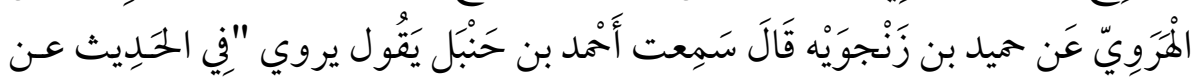

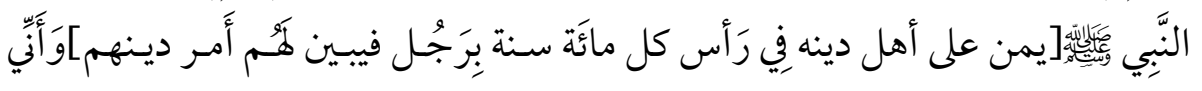

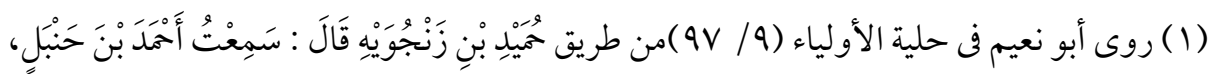

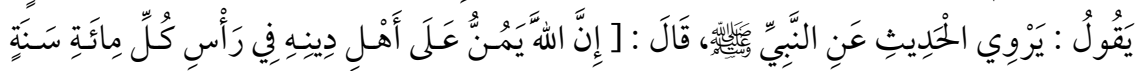

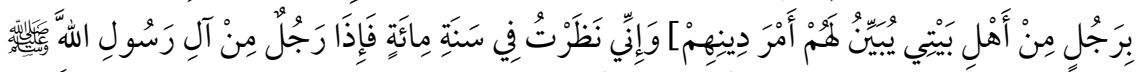

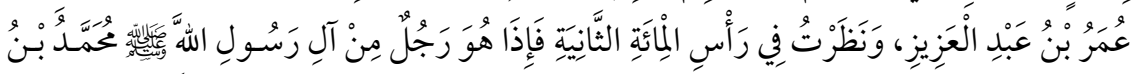

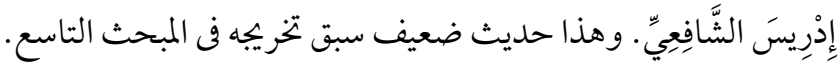

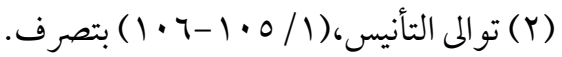




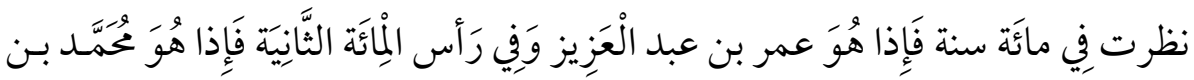

$$
\text { إِدرِيس الشَّافِعِي "(1). }
$$

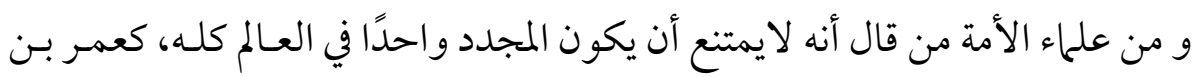

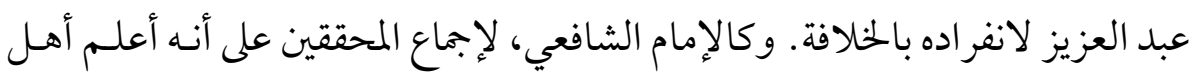
زمانه،

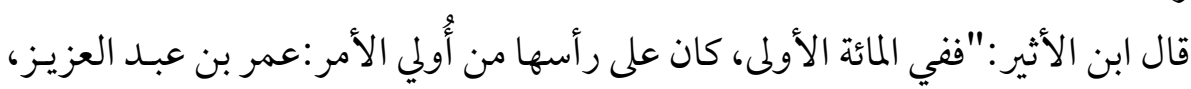

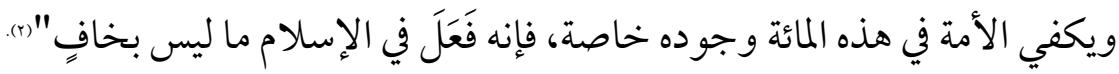

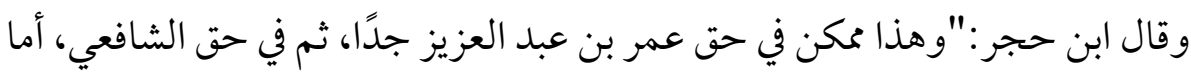

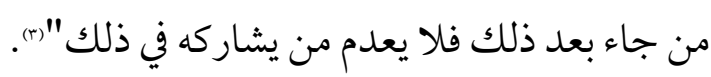

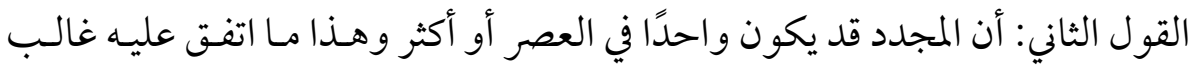

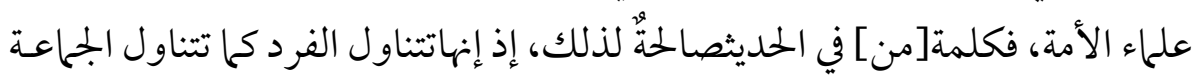

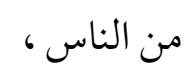

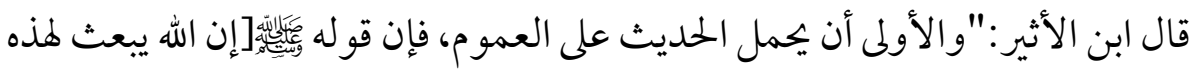

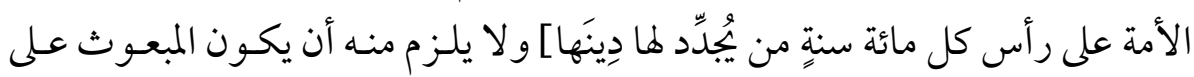

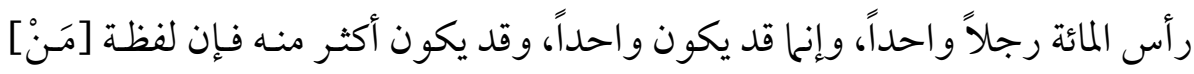

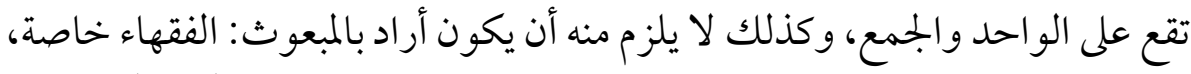

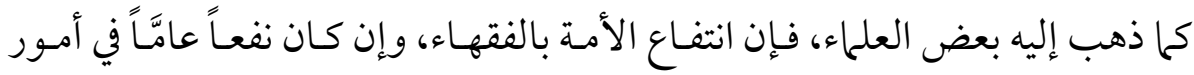

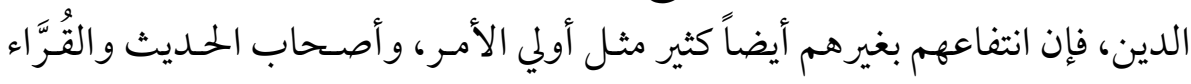

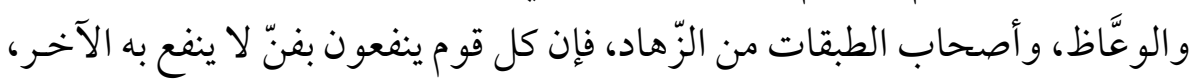

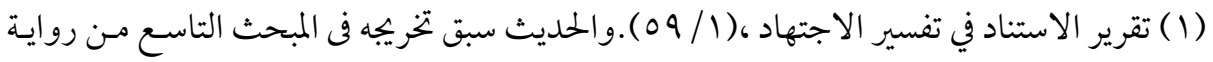

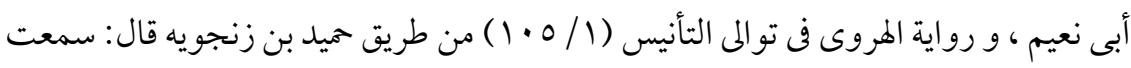

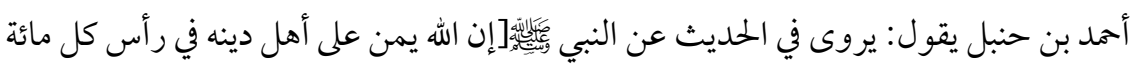

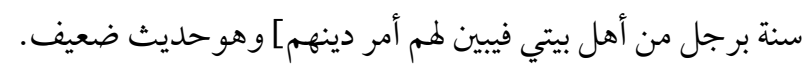

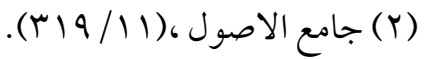

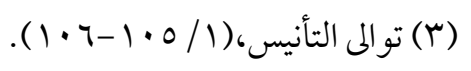


إذ الأصل في حِفْظِ الدِّين حفظُ قانون السياسة، وبث العدل والتناصف الذي به تحقن

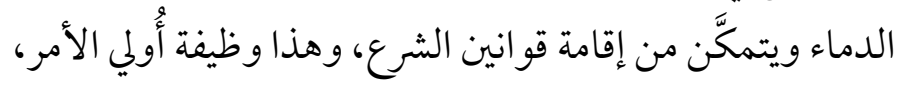

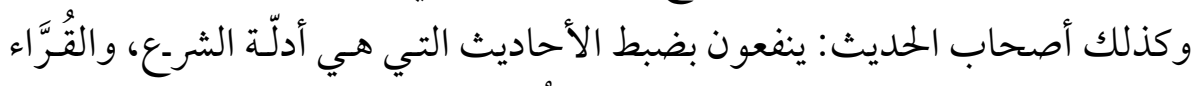

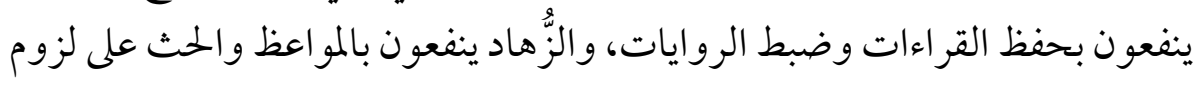

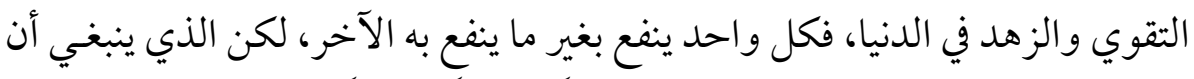

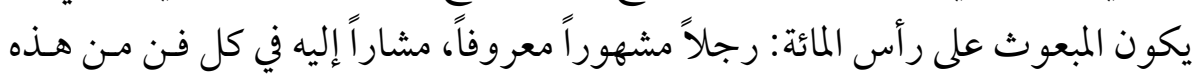

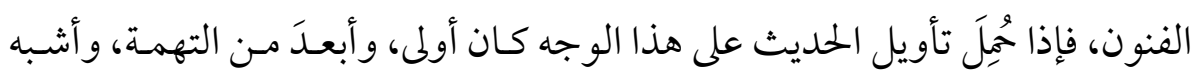

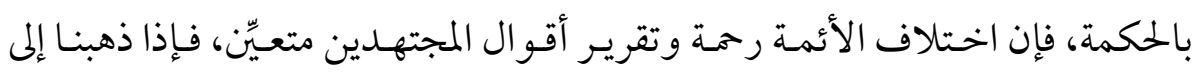

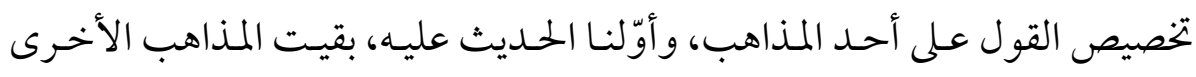
خارجةً عن احتمال الحديث لها، و وكان ذلك الملك طعناً فيها.

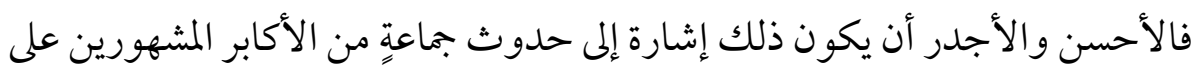

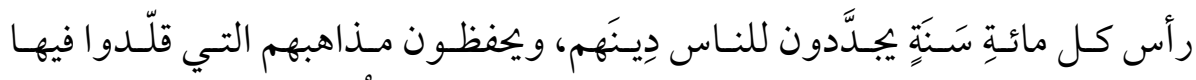

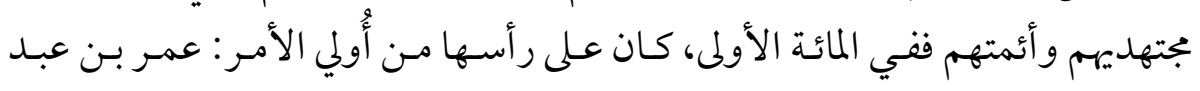

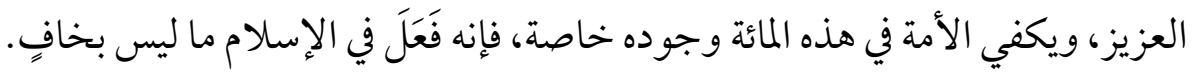

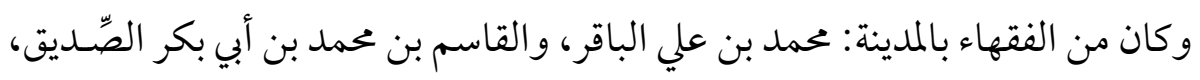

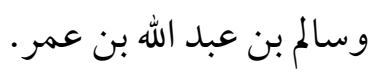

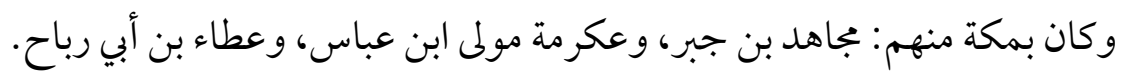

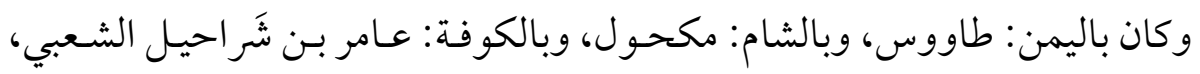

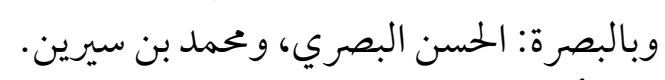
وأما القُرَّاء على رأس المائة الأولى، فكان القائم بها عبد المبد الله بن كثير.

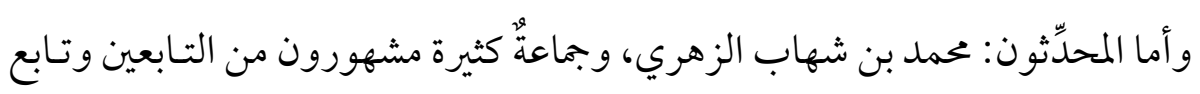

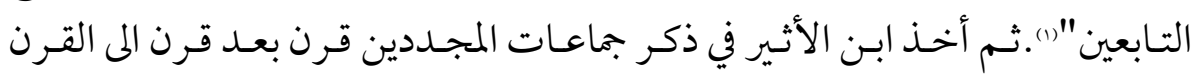

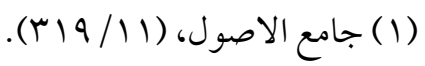




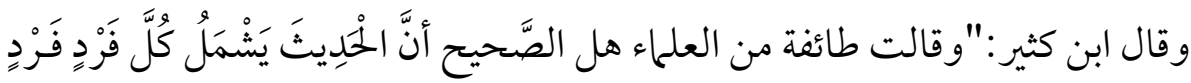

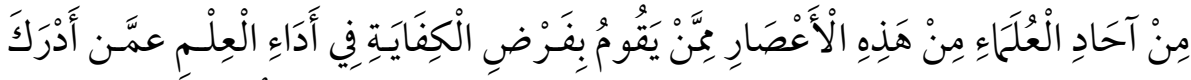

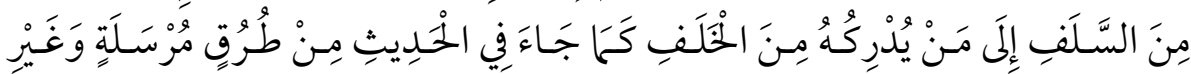

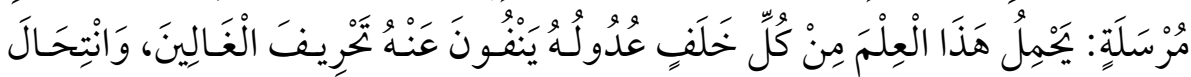

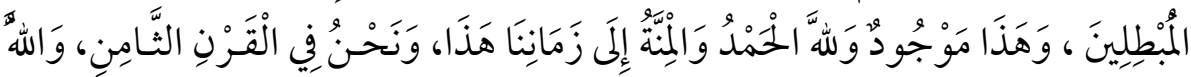

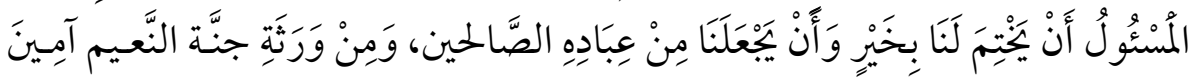

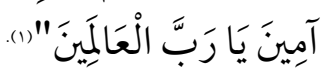

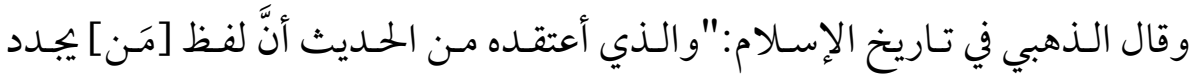

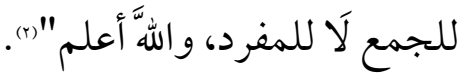

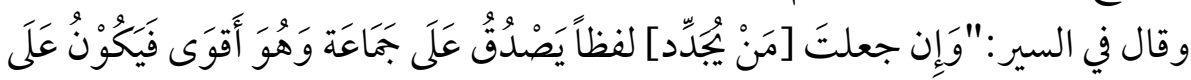
رَأْس المائَة:

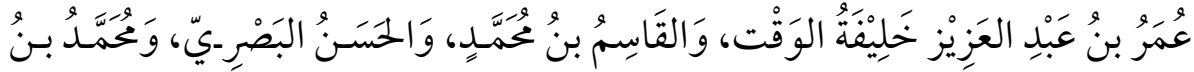

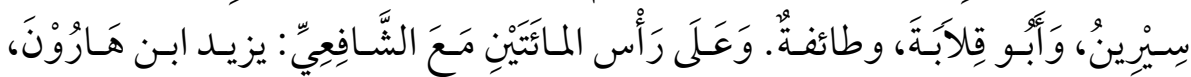

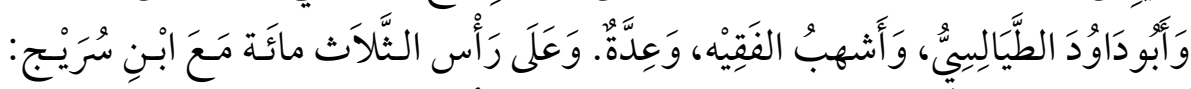

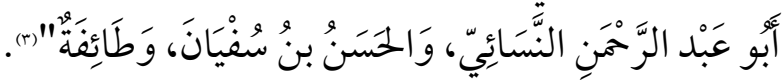

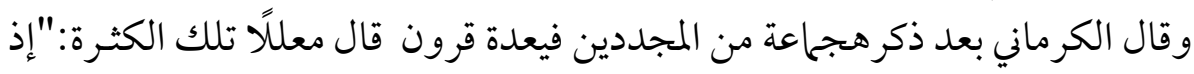

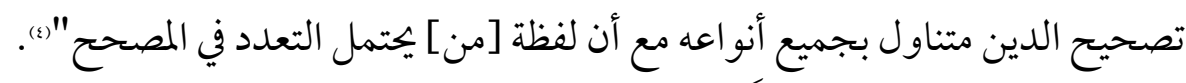

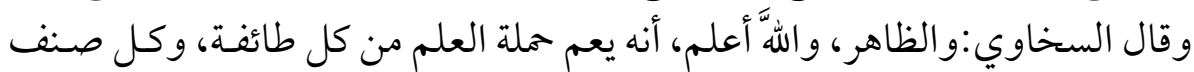

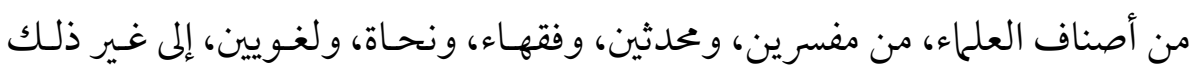
من الأصناف" (من أصناف

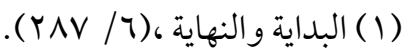

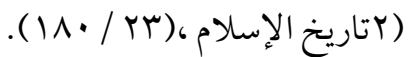

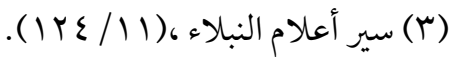

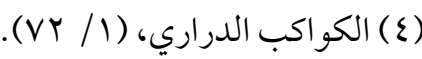

(0) المقاصد الحسنه ، (1/ ع • (Y).
} 


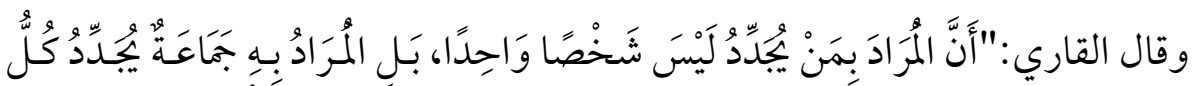

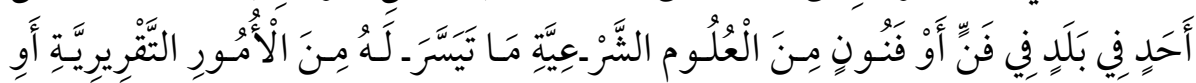

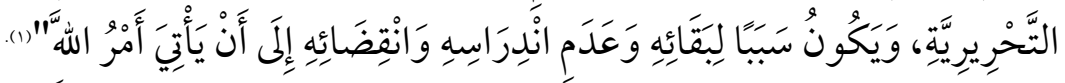

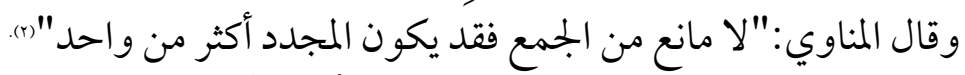

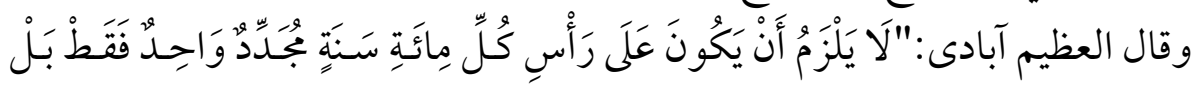

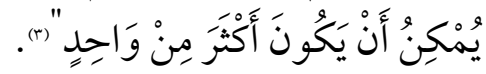
المناقشه:

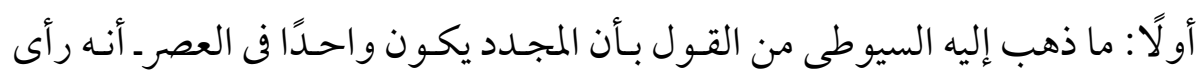

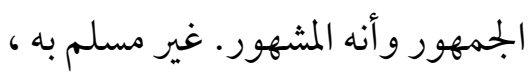

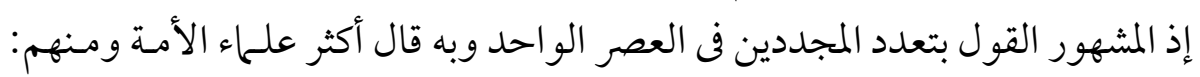

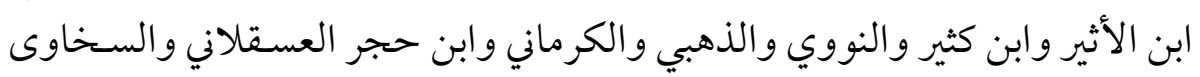

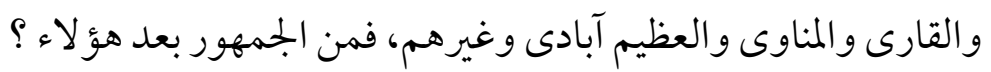

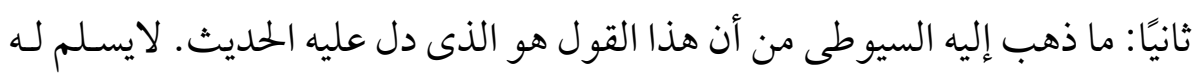

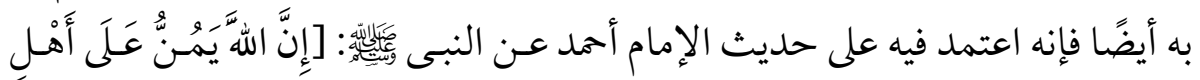

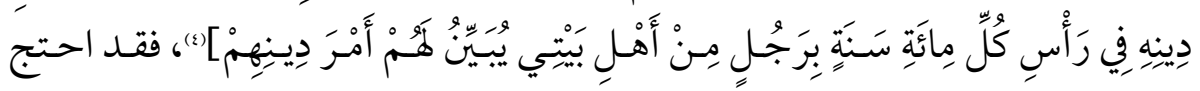

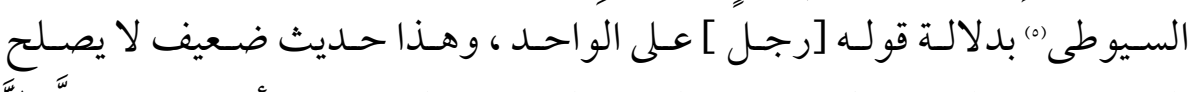

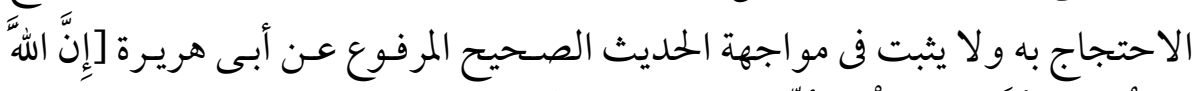

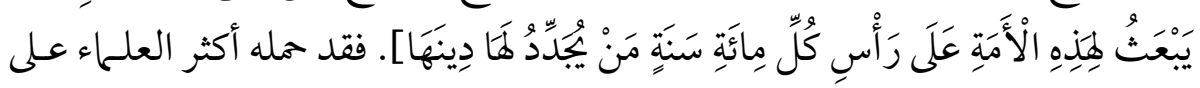

الجمع لئم

ثالثًا: القول بأن المجدد يكون واحدًا في العصر يلزم منه:

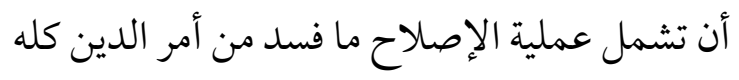

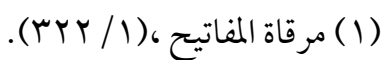

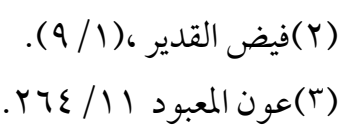

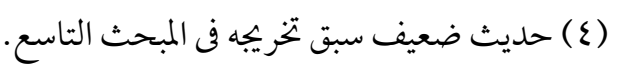

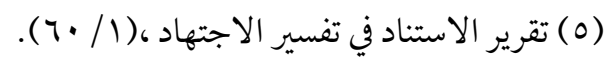




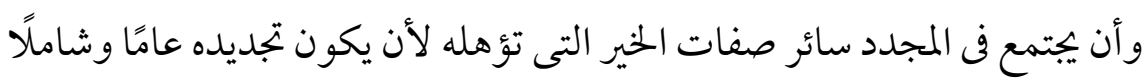

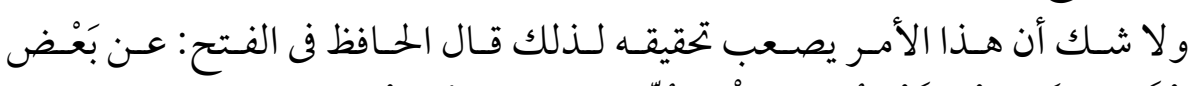

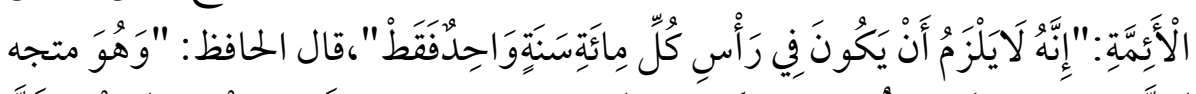

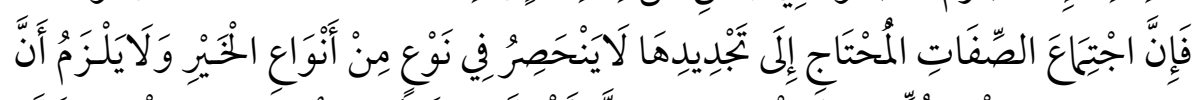

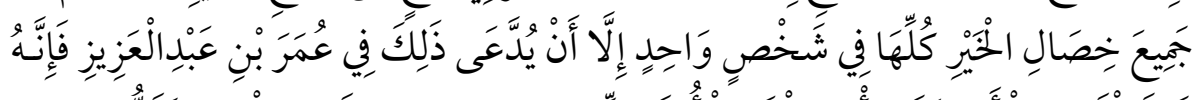

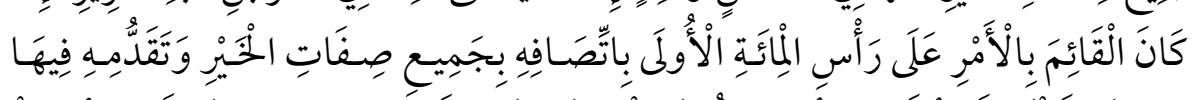

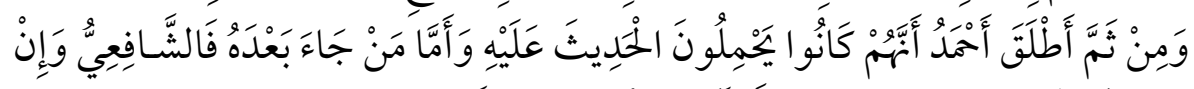

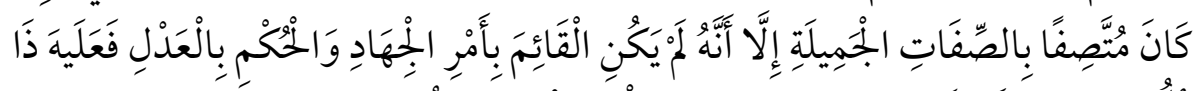

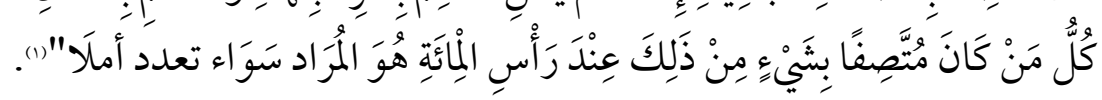

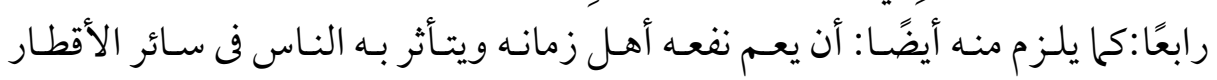

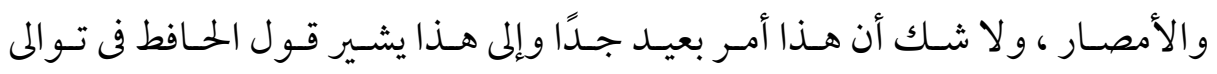

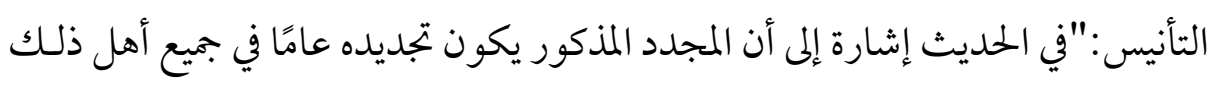

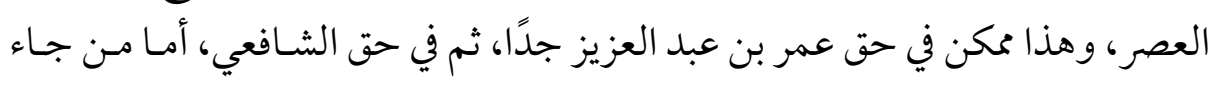

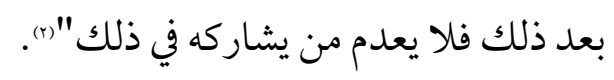

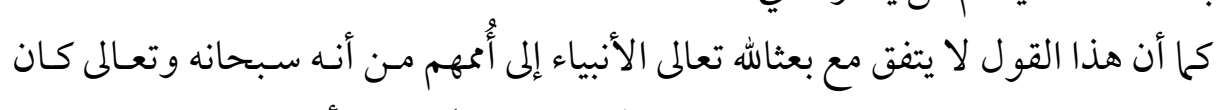

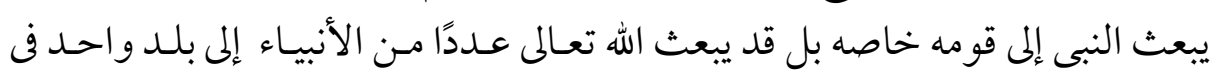
زمان واحد

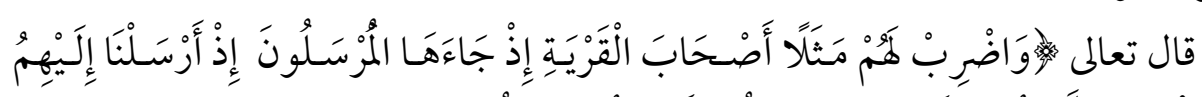

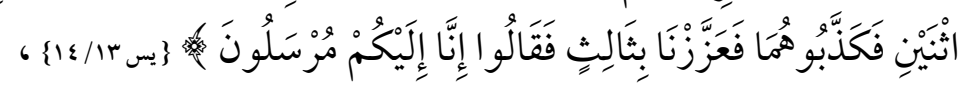

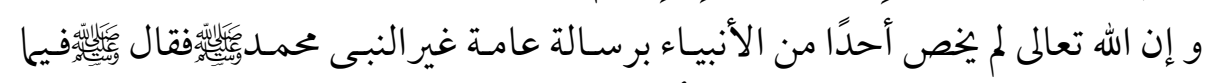

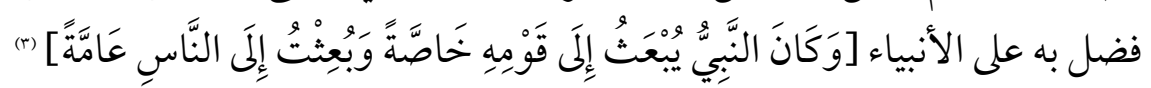

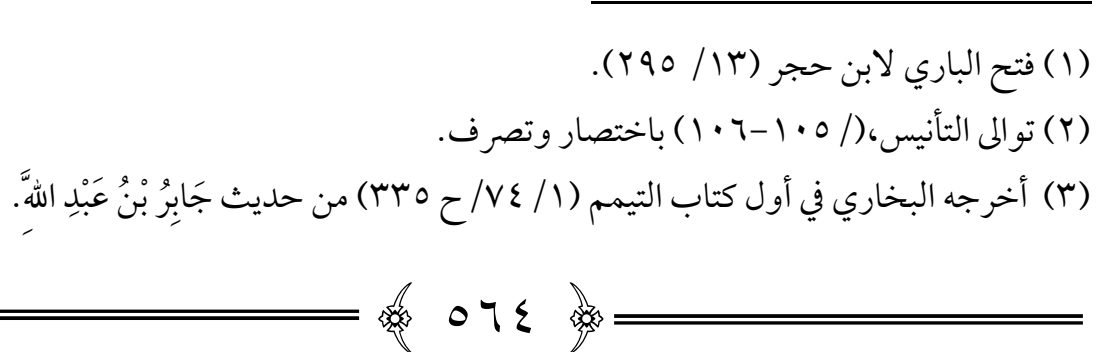




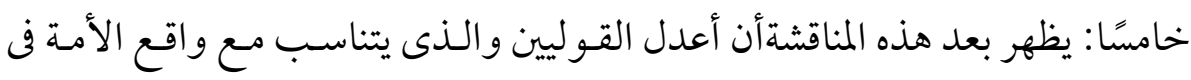

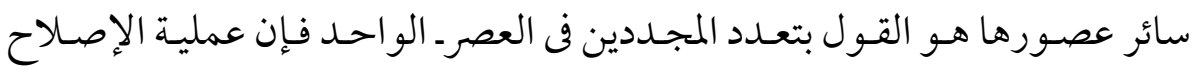

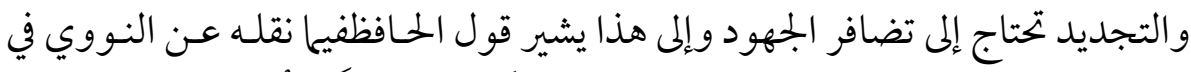

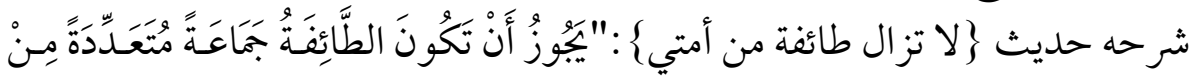

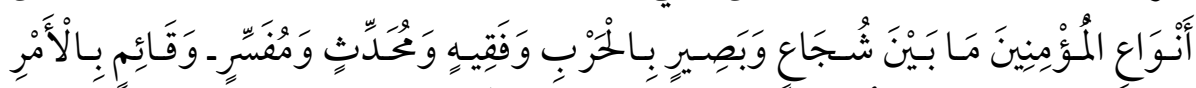

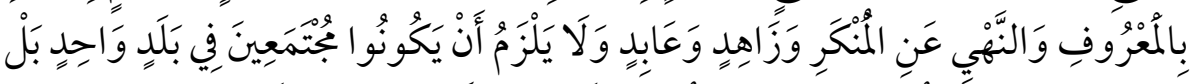

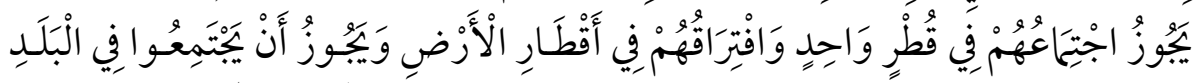

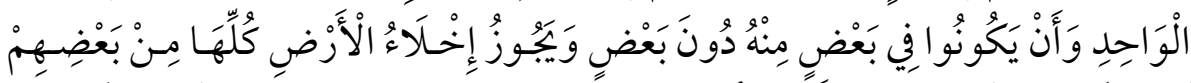

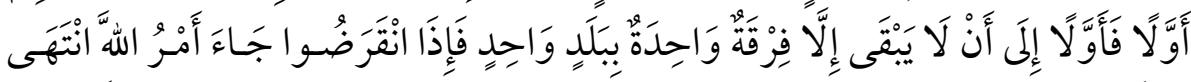

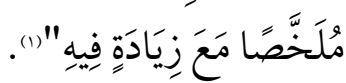

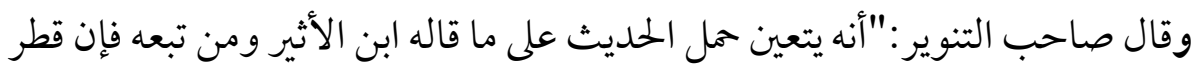

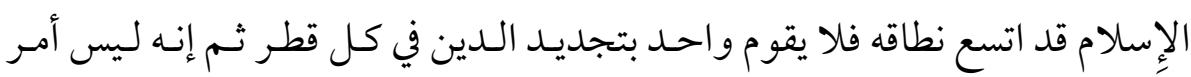

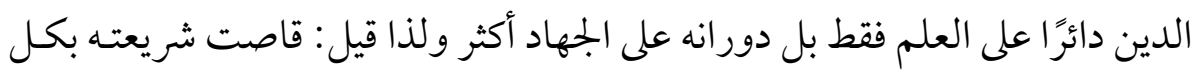

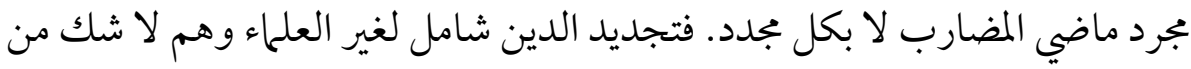

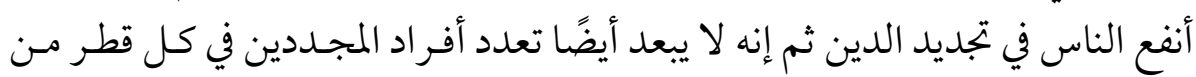

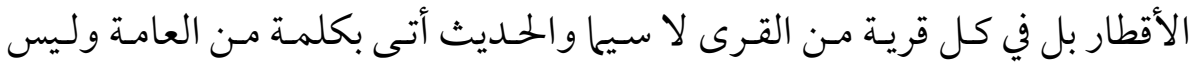

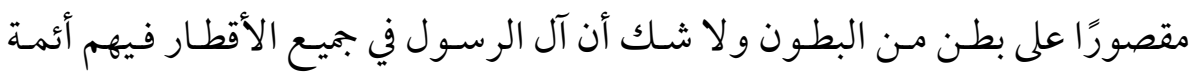

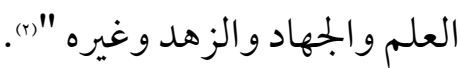

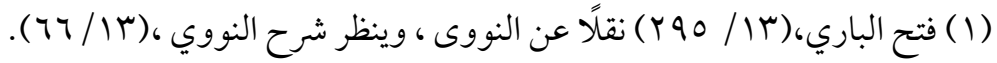

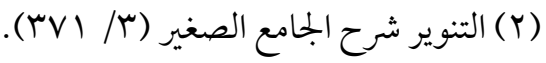




$$
\begin{aligned}
& \text { المبحث الثاني عشر } \\
& \text { المجددون عبر تاريخ الدولة الإسلامية }
\end{aligned}
$$

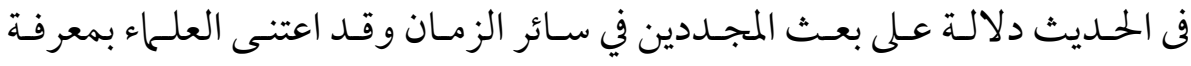

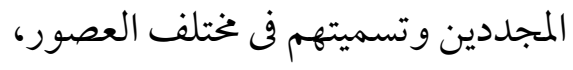$$
\text { وقدأظهرت الدراسة في هذا الجانب أمورًا: }
$$

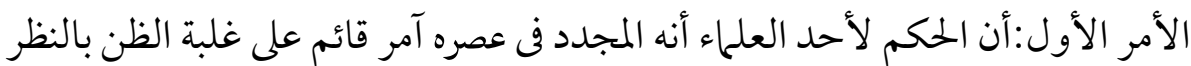

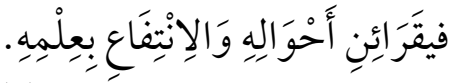

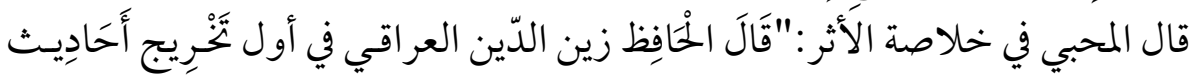

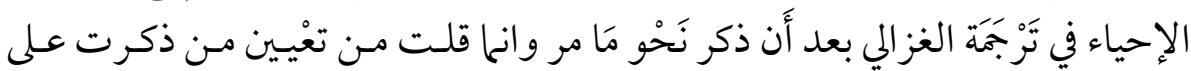

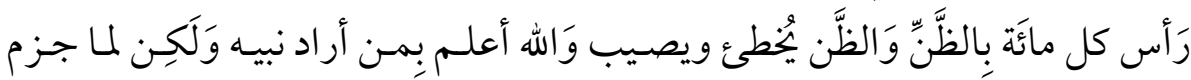

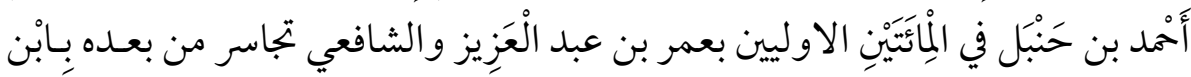

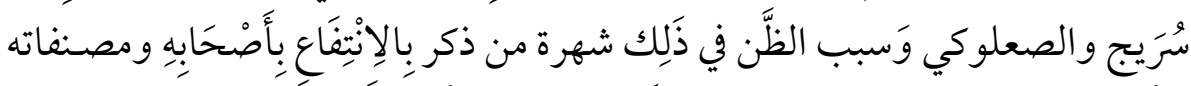

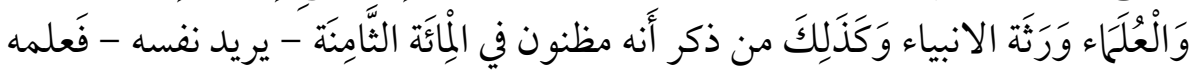

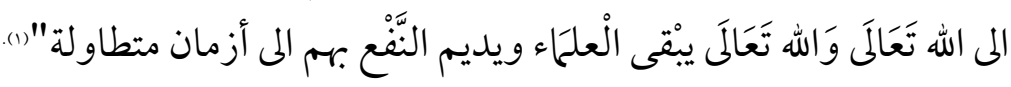

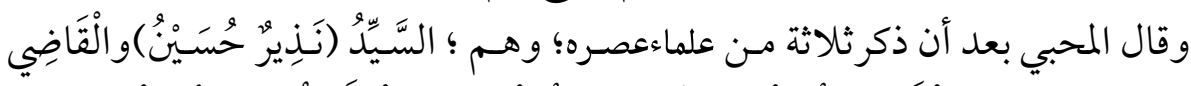

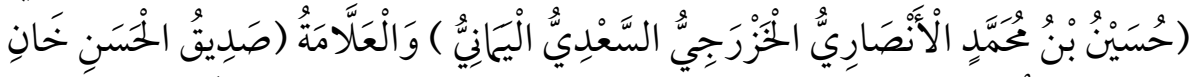

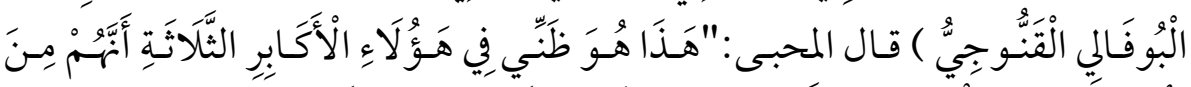

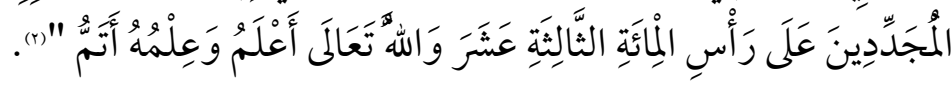

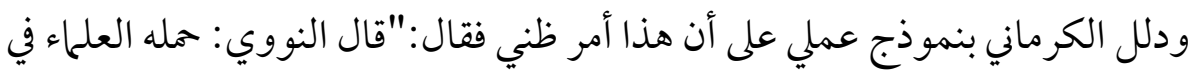

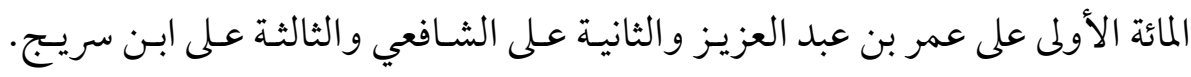

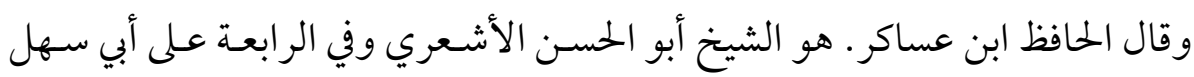

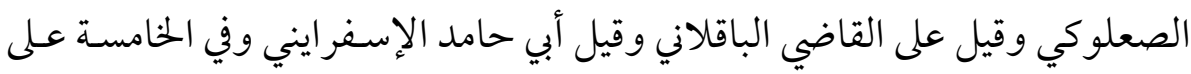

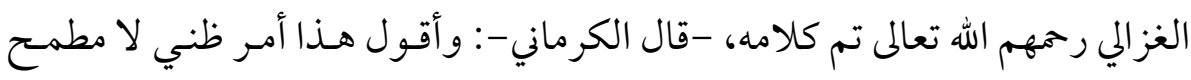

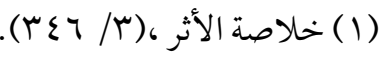
(Y) السابق نفسه. 
لليقـين فيـه فللحنفيـة أن يقـول هـو الحسـن بـن زيـاد في الثانيـة والطحساوي في الثالثـة

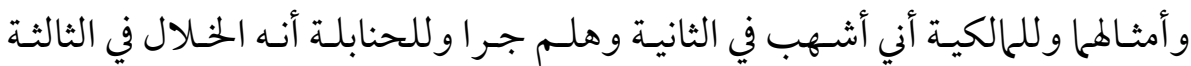

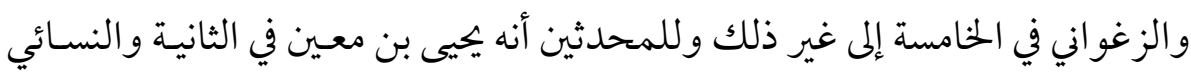

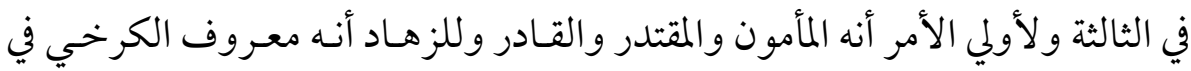
الثانية والشبلي في الثالثة ونحو هما إذ تصحيح الدين متناول بجميع أنواعه مع الثم أن لفظة

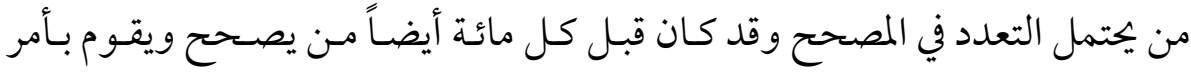

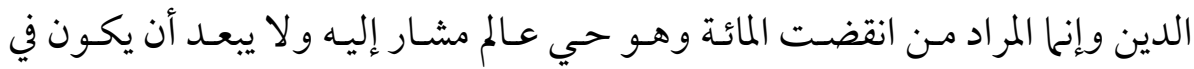

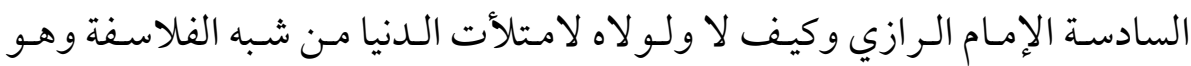
الداعي إلى الله في إثبات القواعد الحقانية وحجة الحق على الخلقق في تصحيح العقائد

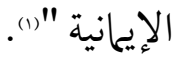

الأمر الثاني:أن الحكم لأحد العلماء أنه المجدد فى عصره أمر وقع فيه اختلاف كبير بين العلماء

وممن أشار من العلماء إلى وجود هذا الاختلاف ؛الذهبي والسبكي:

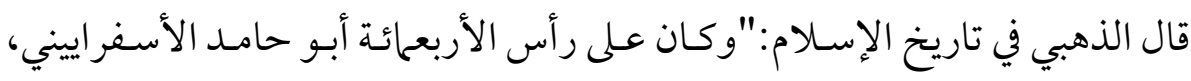

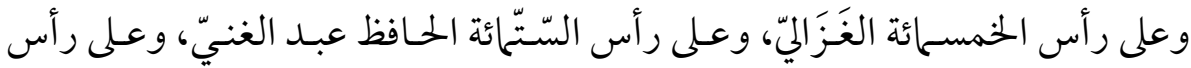
السّبعمائة شيخنا ابن دقيق العِيد.قال الذهبى : (على أن بعضَ هؤ لاء يخالفني فيهم خلق

$$
\text { من العلم|ء)" من (s) }
$$

وهذا يدل على كثرة الاختلاف الو اقع بين العلماء في هذا الأمر

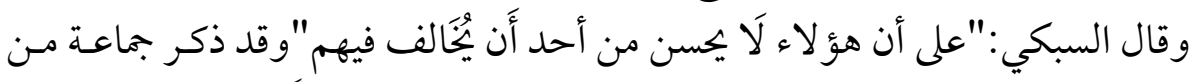

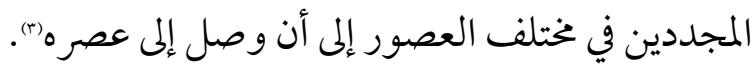

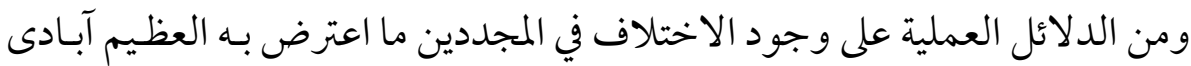

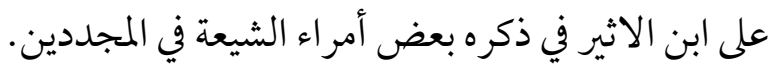

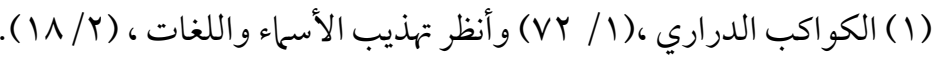

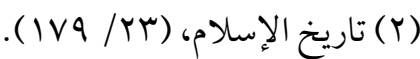

$$
\begin{aligned}
& \text { (Y) طبقات الشافعيه الكبرى، (I/ . . (Y). }
\end{aligned}
$$




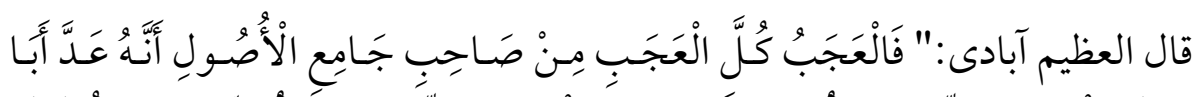

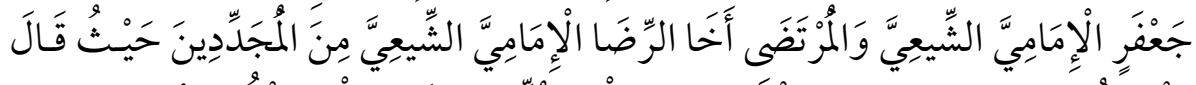

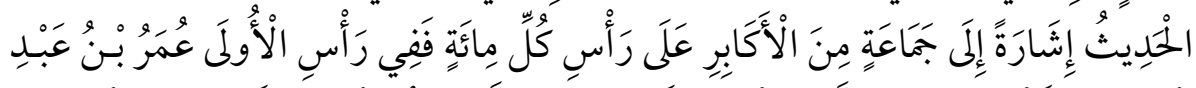

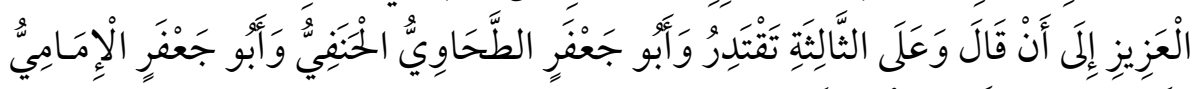

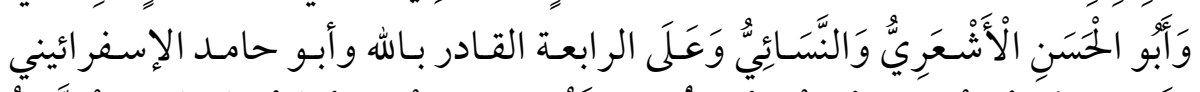

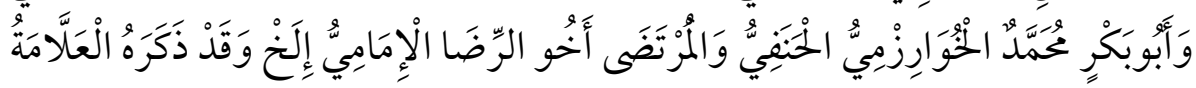

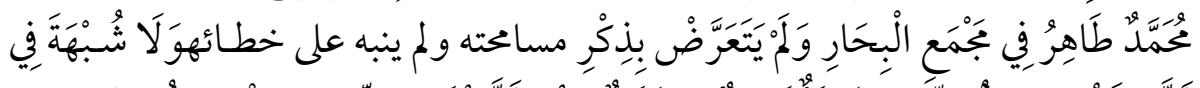

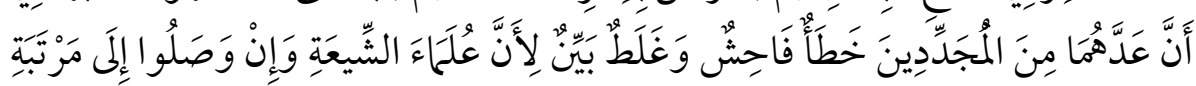

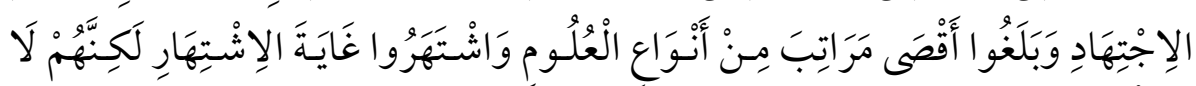

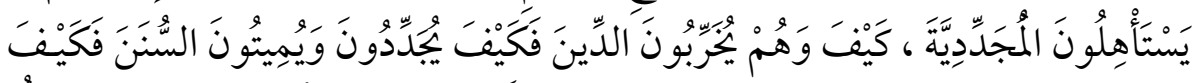

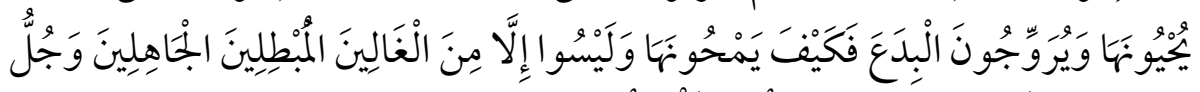

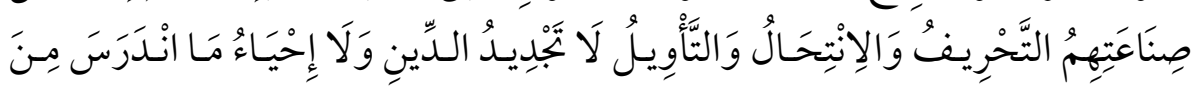

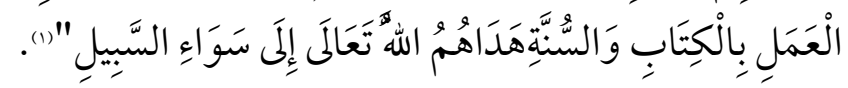

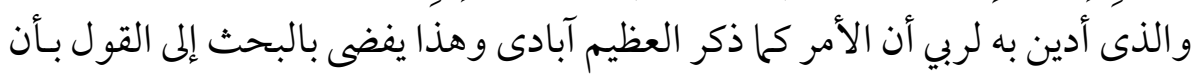

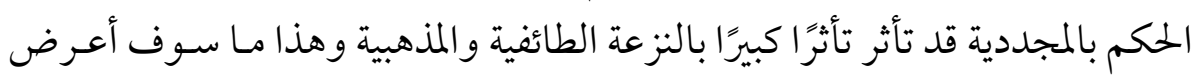

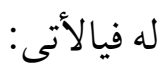

الأمر الثالث:أن الحكم بالمجددية أمر قد ظهرت فيه النزعة الطائفية والمذهبية

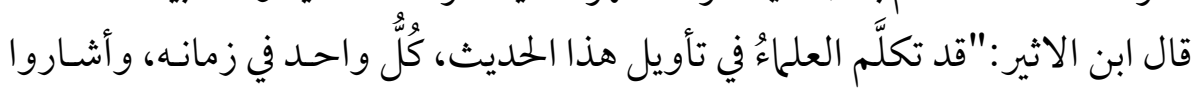

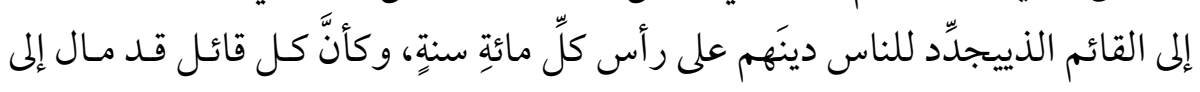

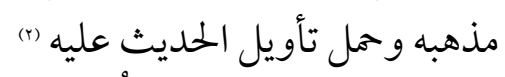

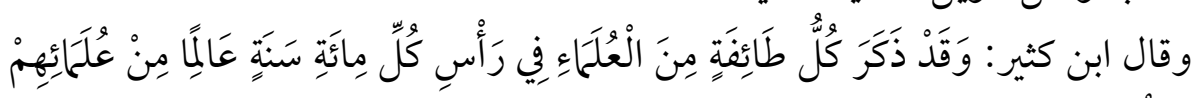

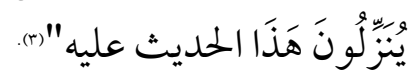

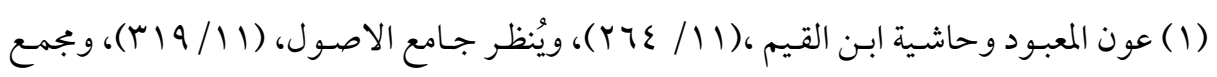

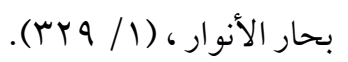

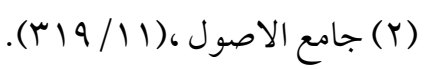

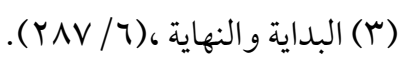


ومن الدلائل التطبيقية على وجود النزعة الطائفية والمذهبية فى اختيار المجدد:

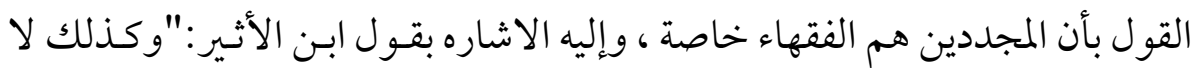

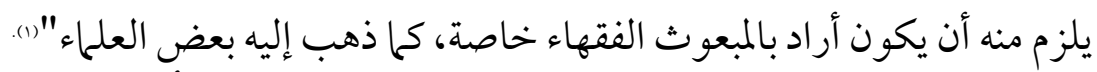

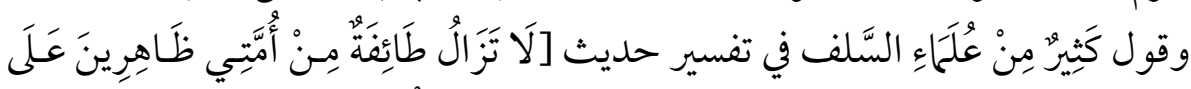

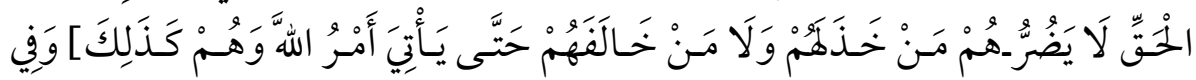

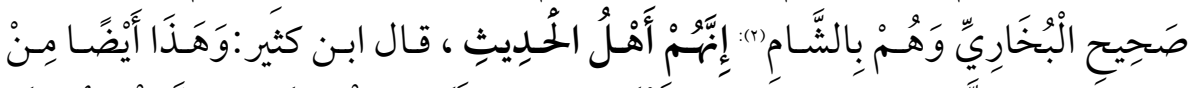

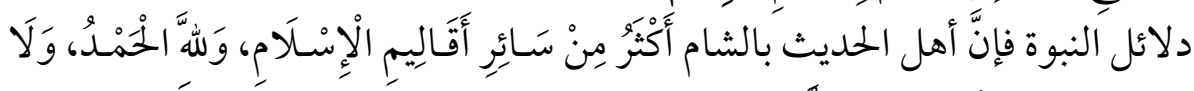

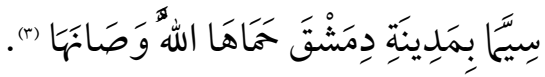

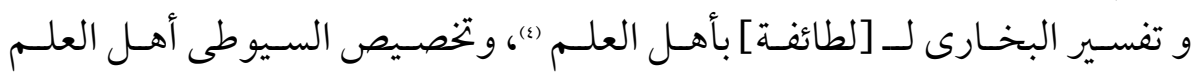

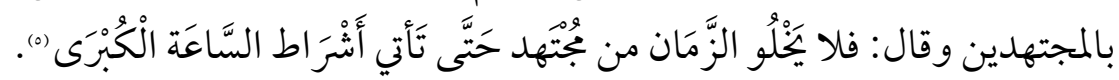

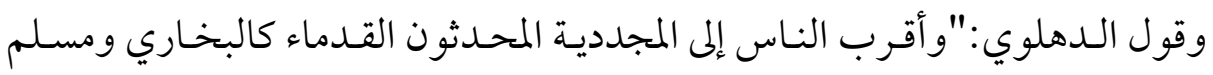

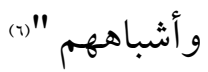

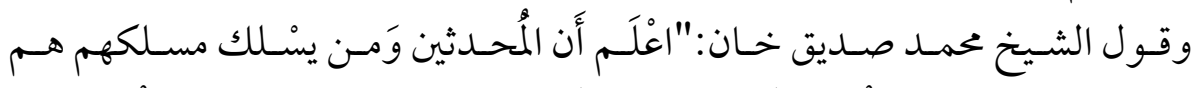

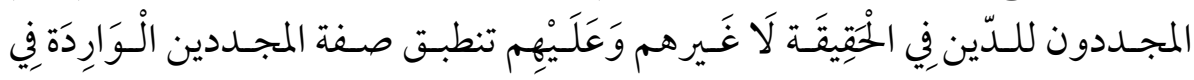

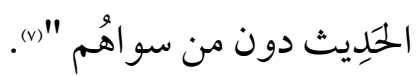

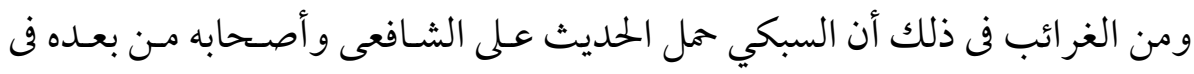

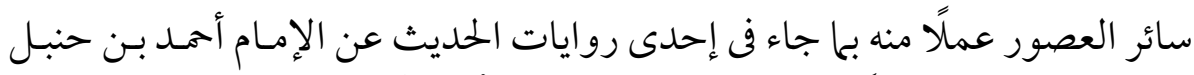

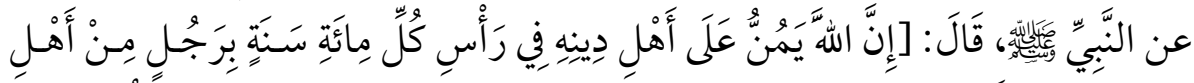

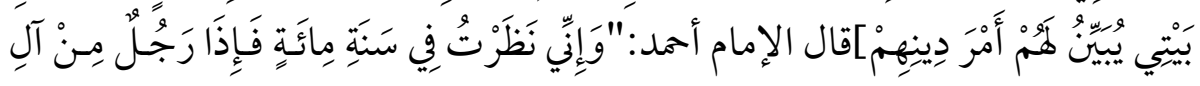

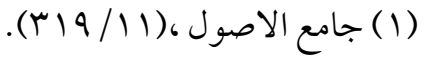

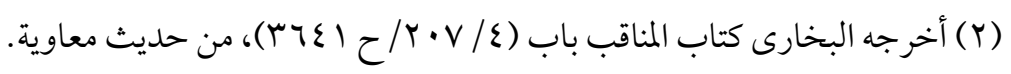

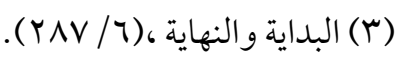

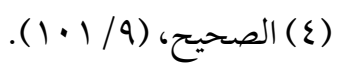

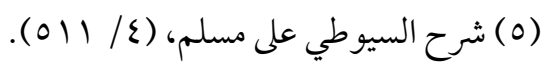

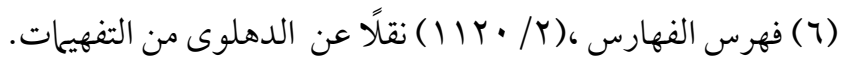

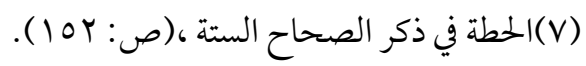




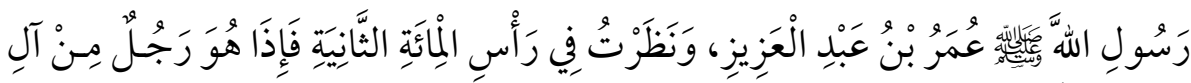

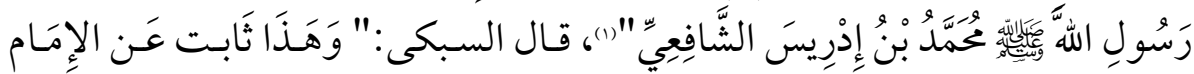

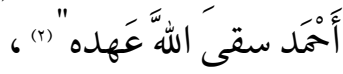

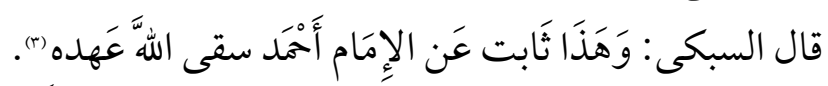

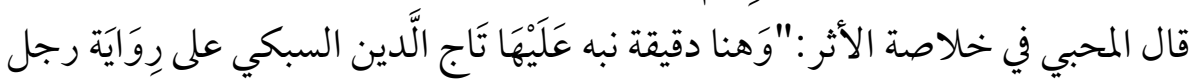

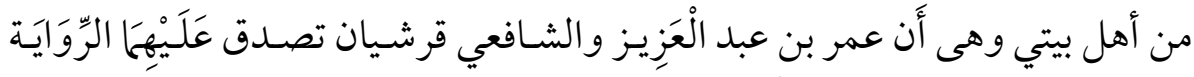

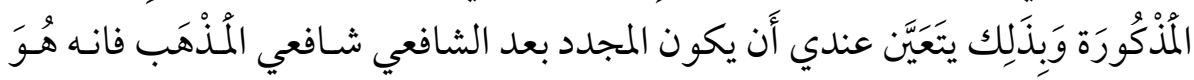

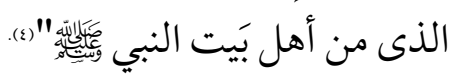

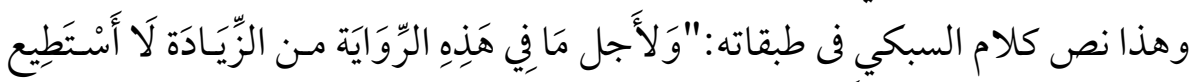

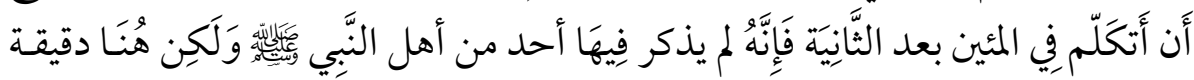

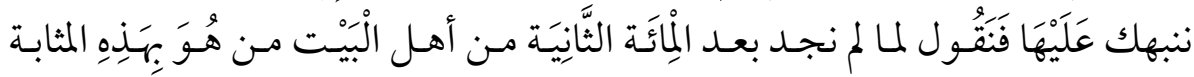

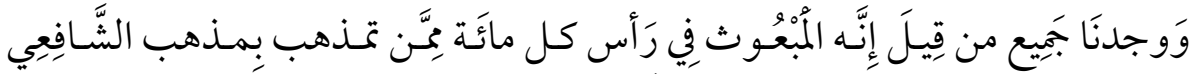

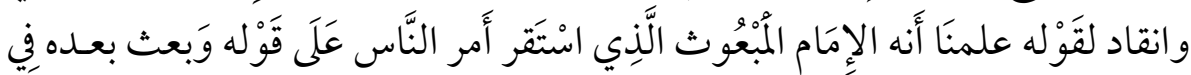

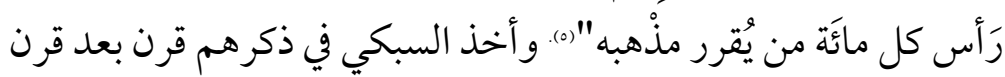
وإلى عصره.

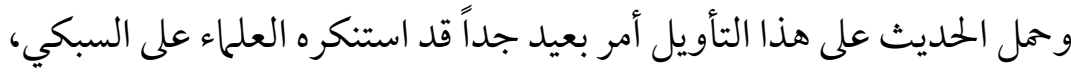

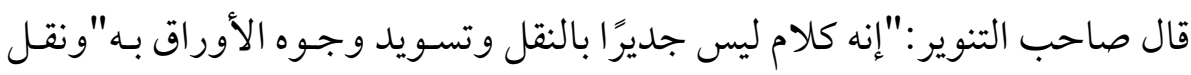

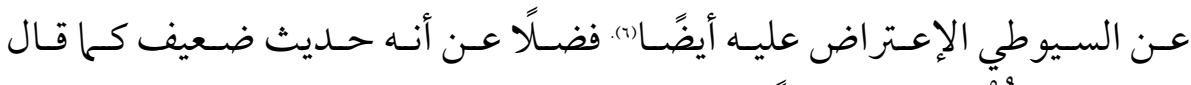

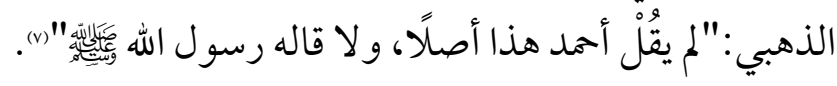

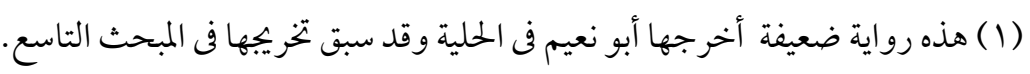

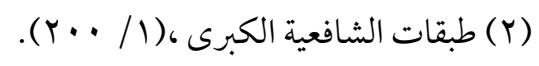
(Y) (Y) السابق نفسه.

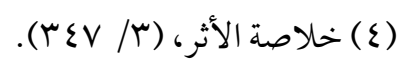

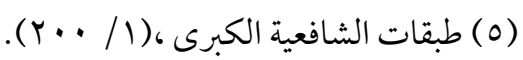

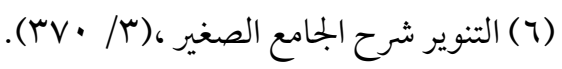

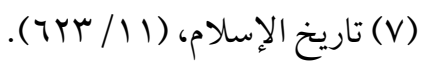


وعلى فرض ثبوت الحديث كما قال السبكي في حمل كما قال بعضهم على أَنَ المُرَادِبِكَوْنِهِ

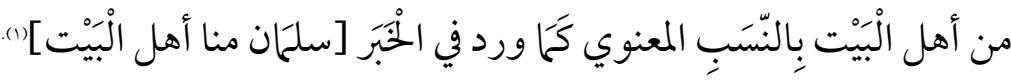

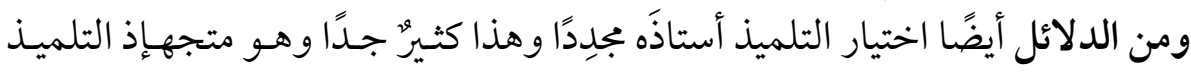
أعرف الناس بشيخه ومنه على سبيل المثال :

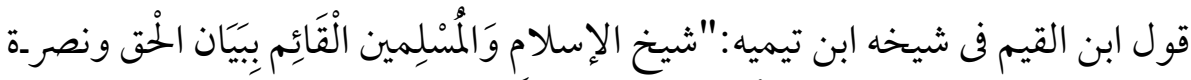

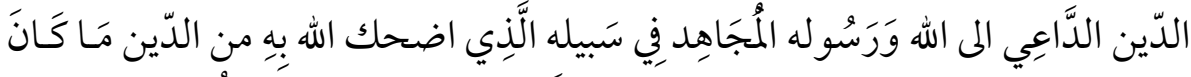

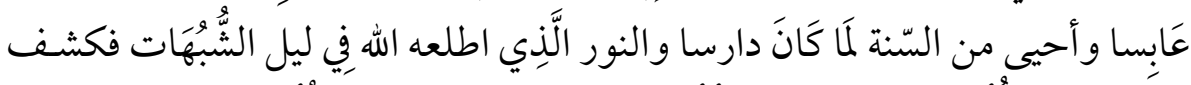

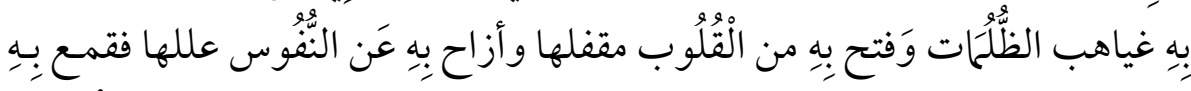

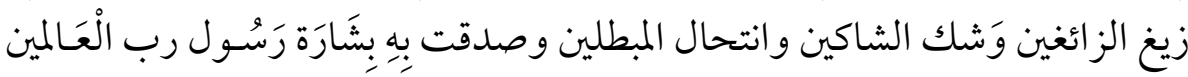

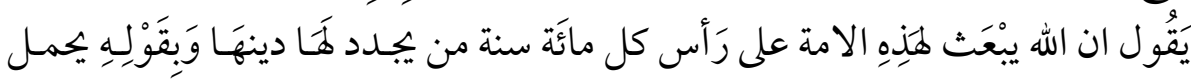

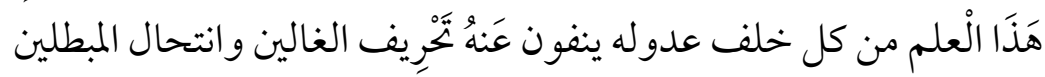

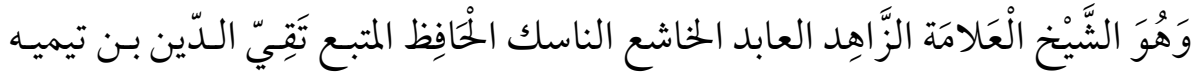

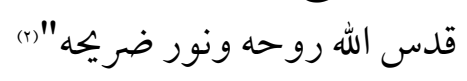

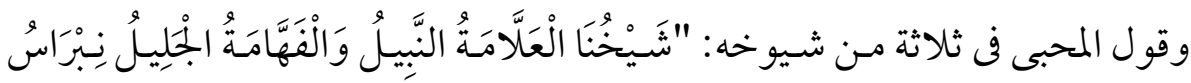

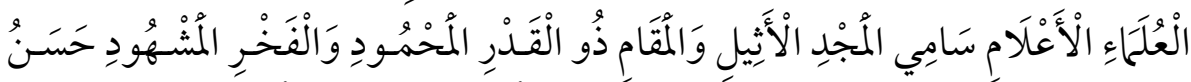

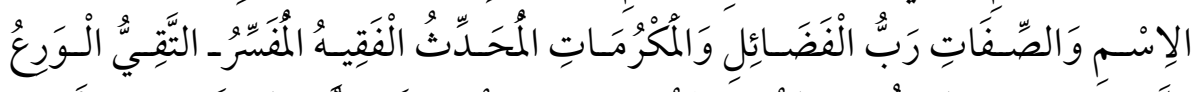

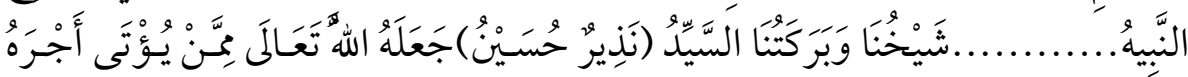

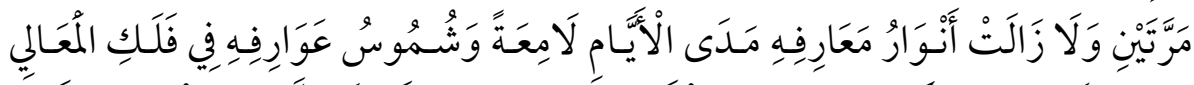

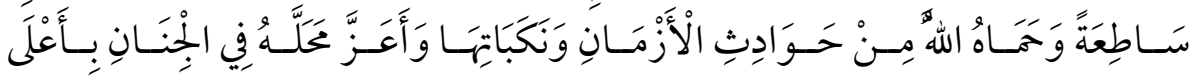

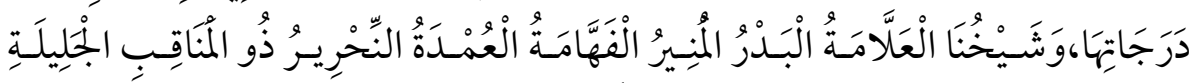

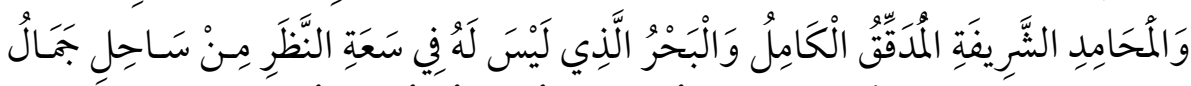

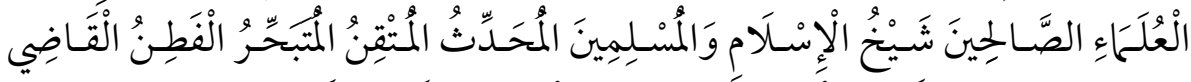

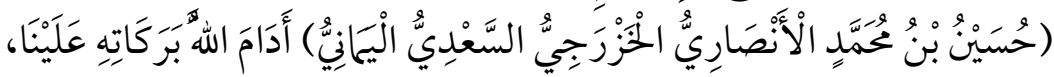

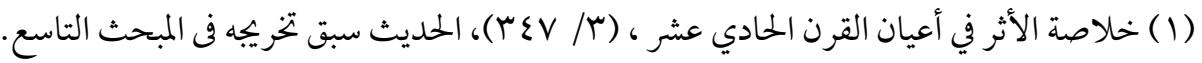

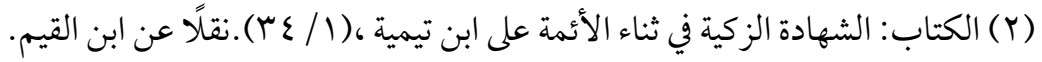




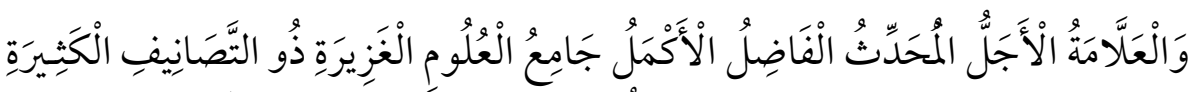

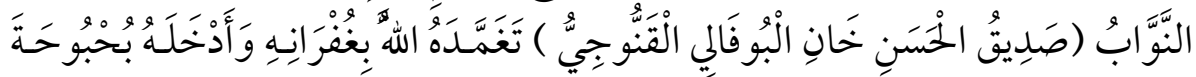

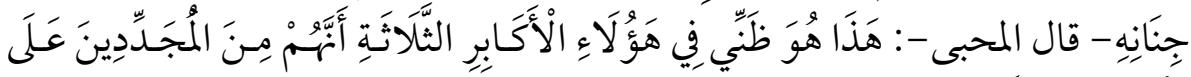

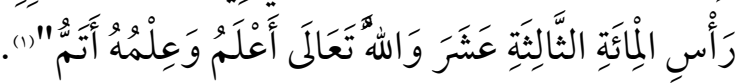

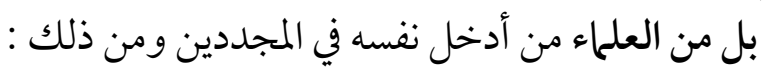

$$
\begin{aligned}
& \text { قول السيوطي عن نفسه فيأرجوزته: }
\end{aligned}
$$

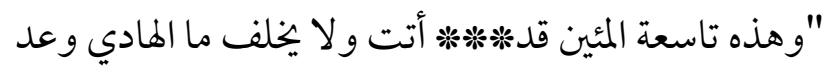

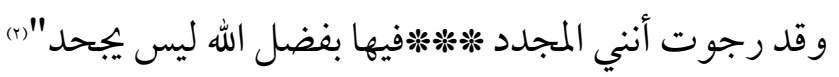

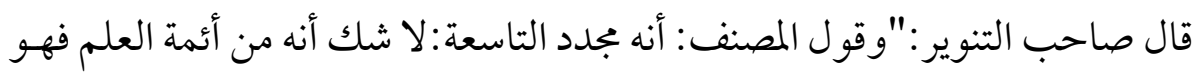
من مجدديها بتأليفه التي ملأت الدنيا وقربت كثيرًا من الفنون فهو منهم لا أنه منحصر.

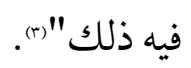

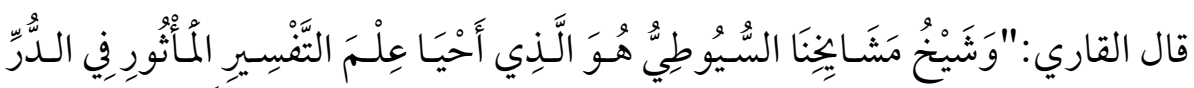

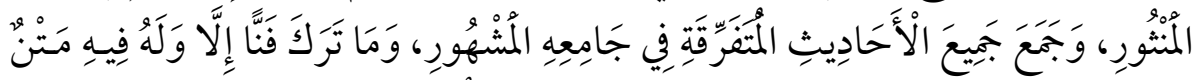

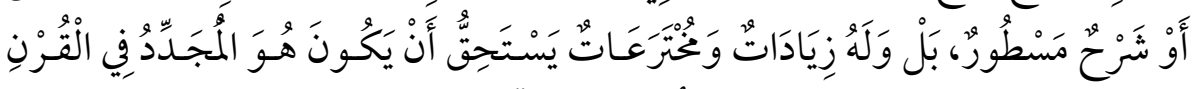

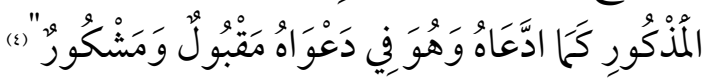

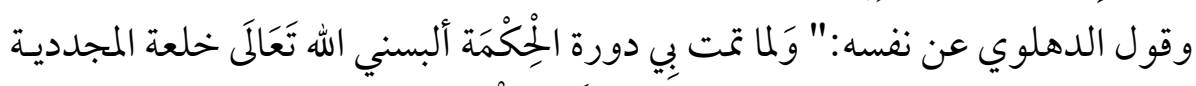

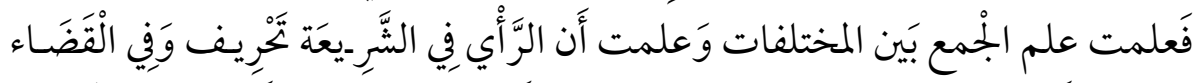

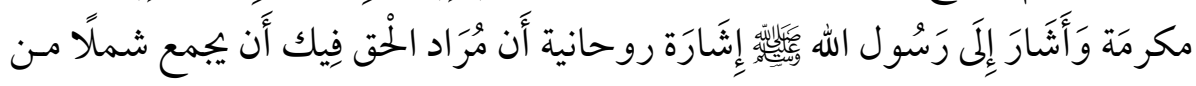

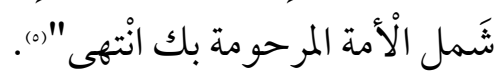

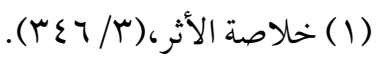

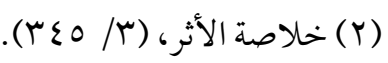

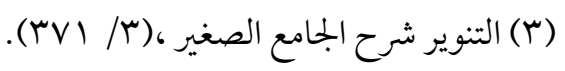

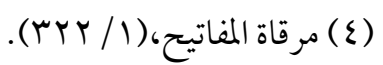

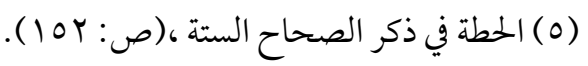




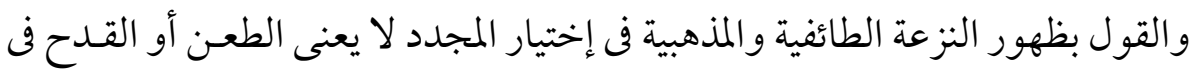

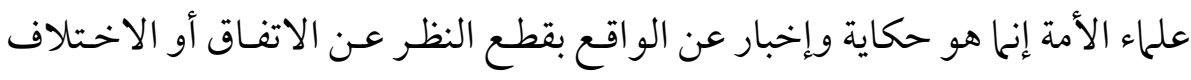

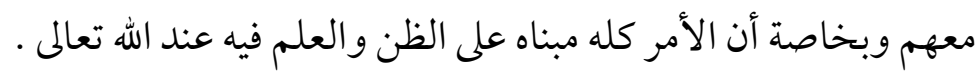

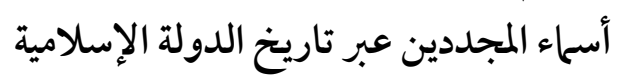

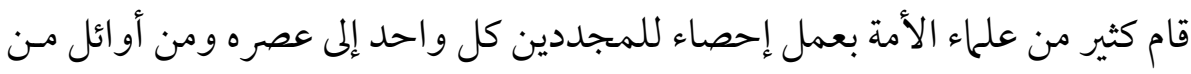

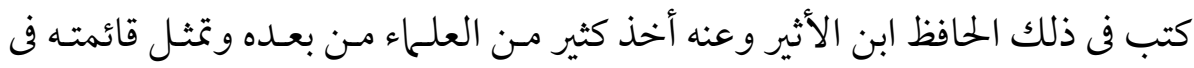

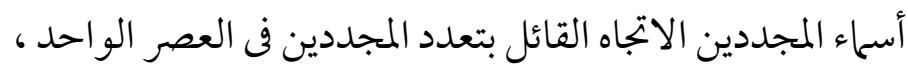

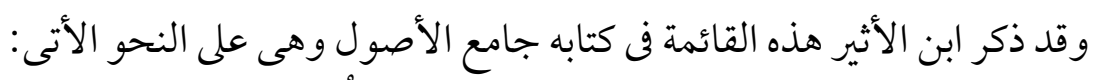

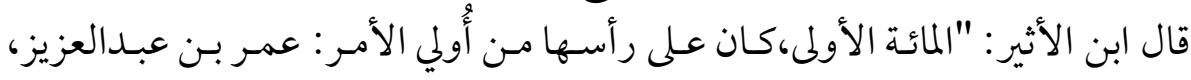

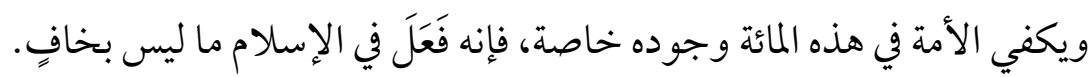

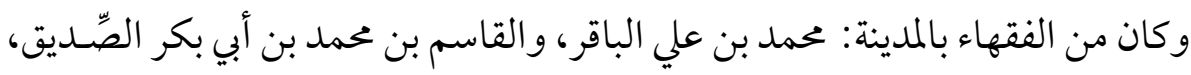
وسالم بن عبداله بن عمر.

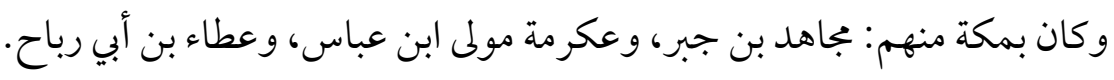

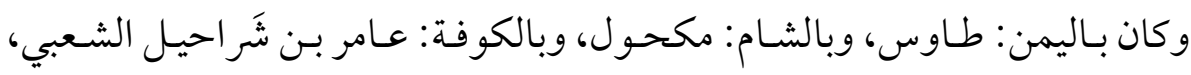
وبالبصرة: الحسن البصري، ومحمد بن سيرين.

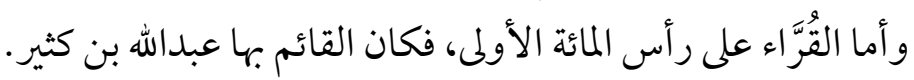

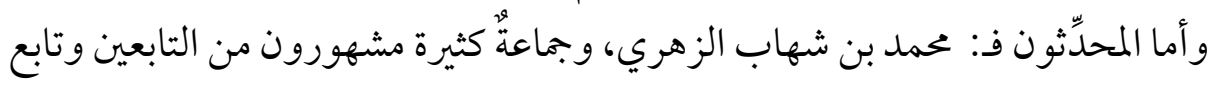
التابعين. وأما من كان على رأس المائة الثانية، فمن أُولي الأمر: المأمون بن الرشيد، ومن الفقهاء:

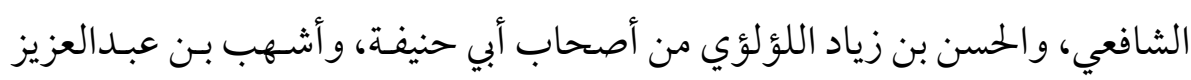

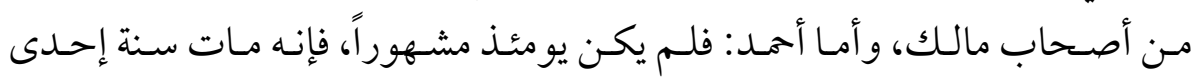
و وأربعين ومائتين.

ومن الإمامية: علي بن موسى الرضى، ومن القراء: يعقوب الحضرمي، ومين ومن المحدّثين:

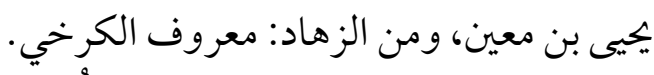

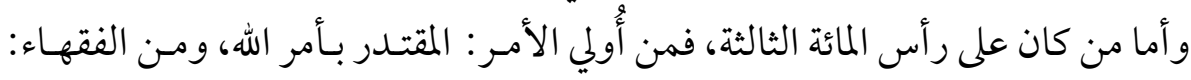

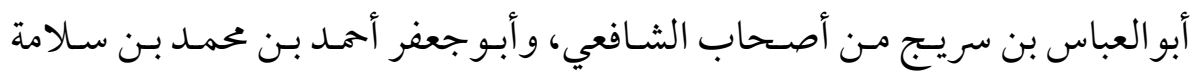


الطحاوي من أصحاب أبي حنيفة،... من أصحاب مالك، وأبوبكر بن هارون الخلال

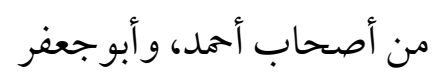

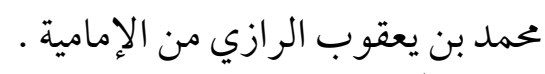

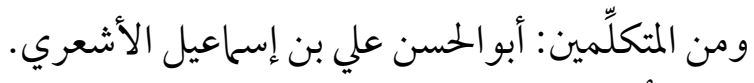

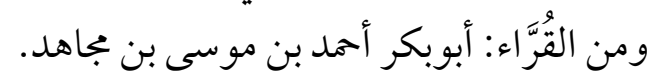

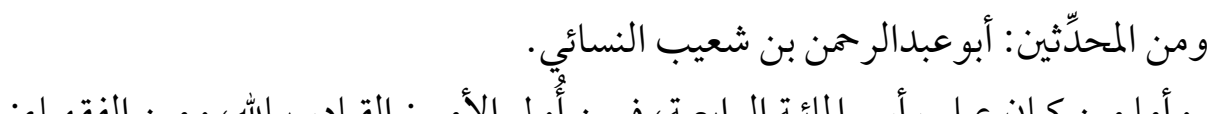

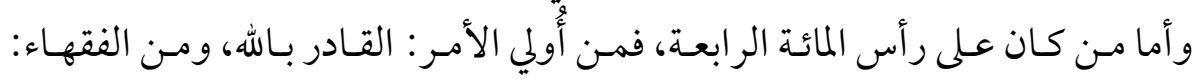

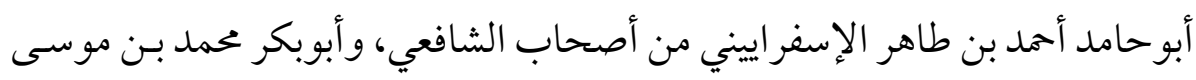

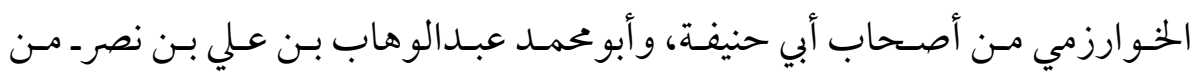

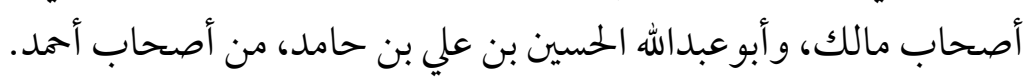

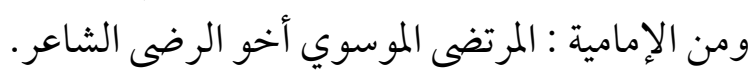

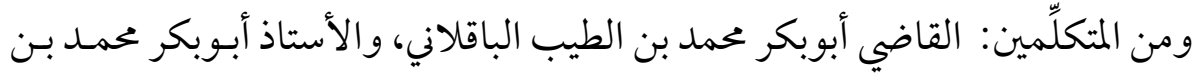

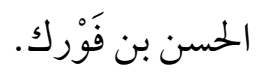
ومن المحدِّيّين: أبوعبد الله محمد بن عبدالله النيسابوري المعروف بالحاكم [ابن] البيّع.

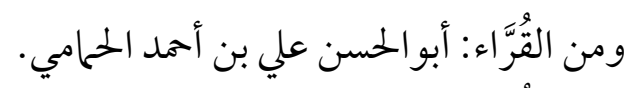

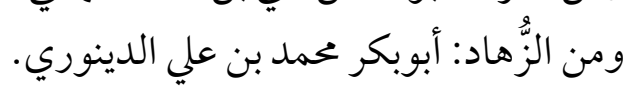

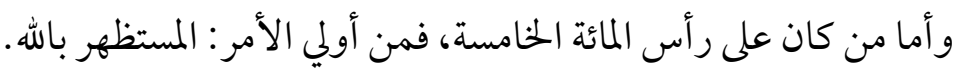

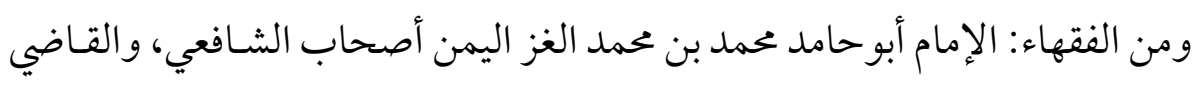

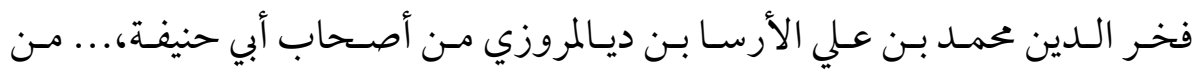

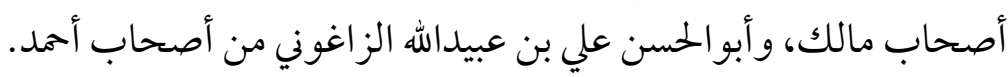

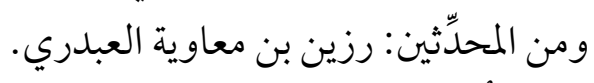

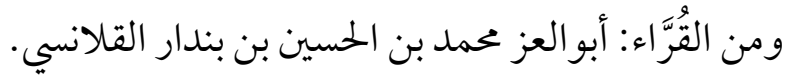

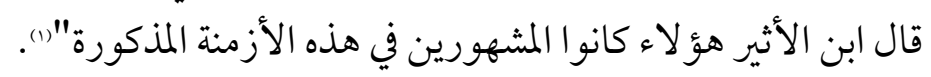

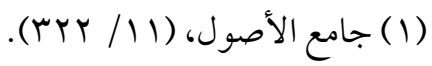
ovะ 


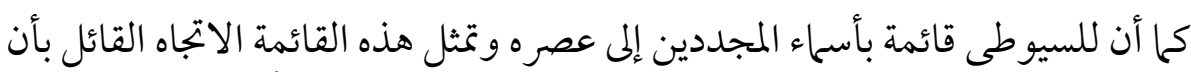

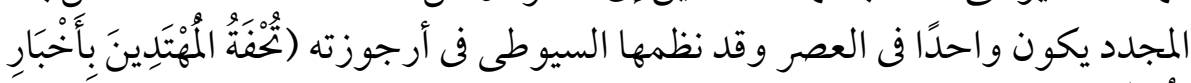

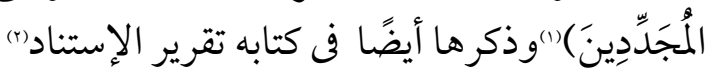

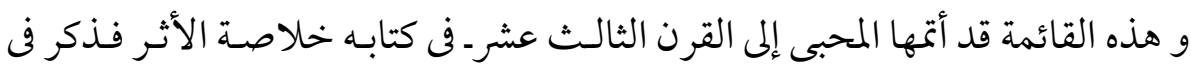

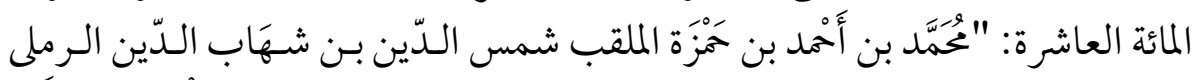

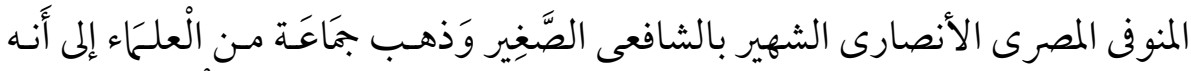

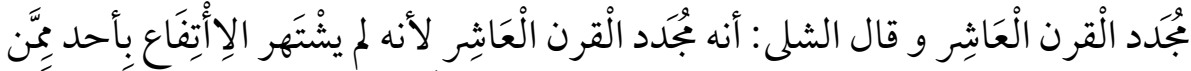

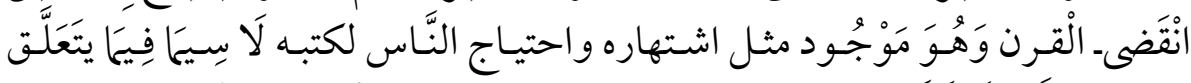

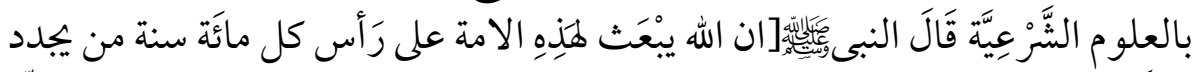

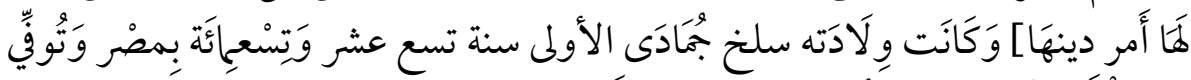

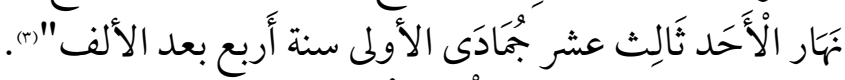

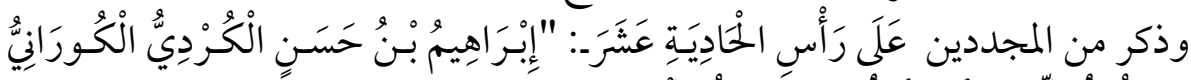

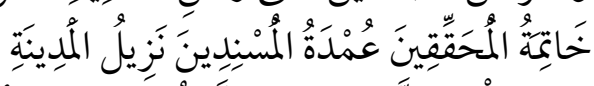

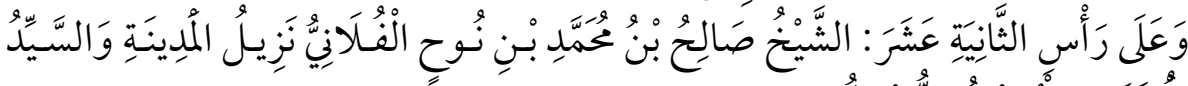

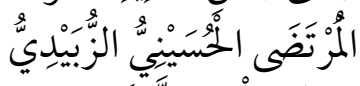

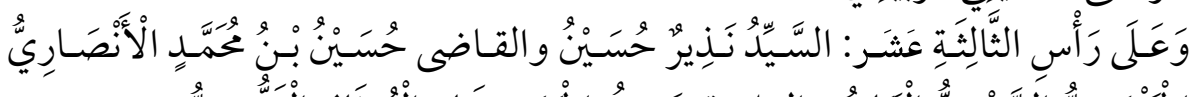

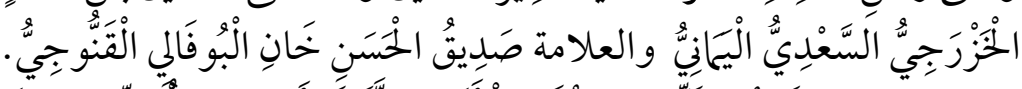

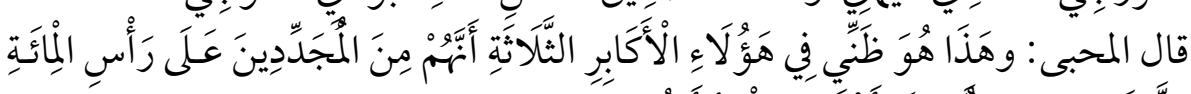

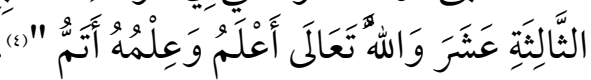

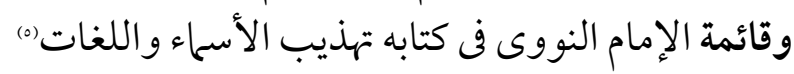

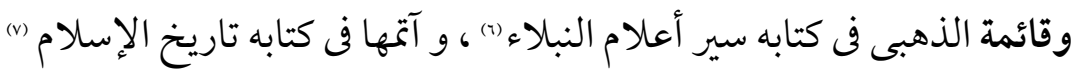

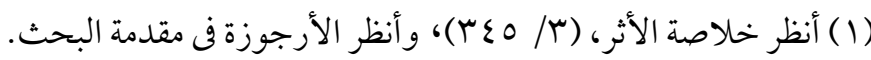

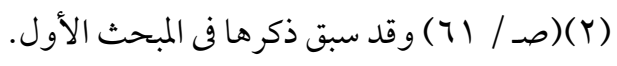
( )

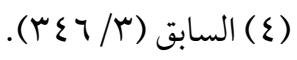
. (IN/Y)(0) . $(1 Y \varepsilon / 11)(T)$ (IVQ/rr) (V) 
وقائمة الكرمانى فى كتابه الكو اكب الدرارى (1)

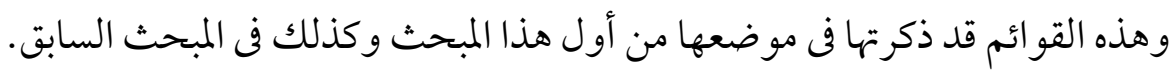

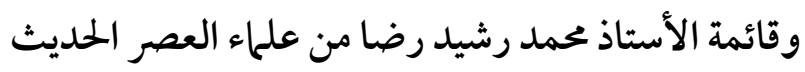

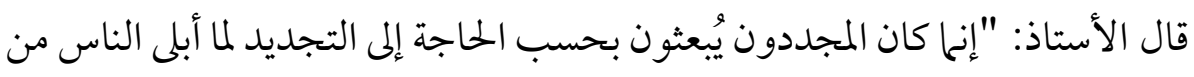

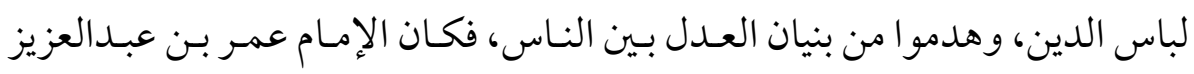

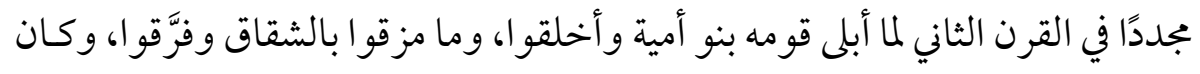

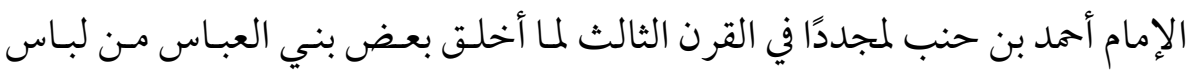

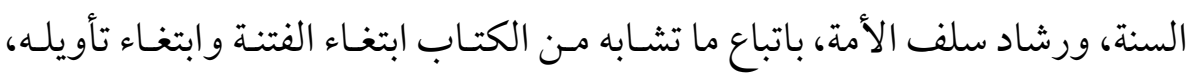

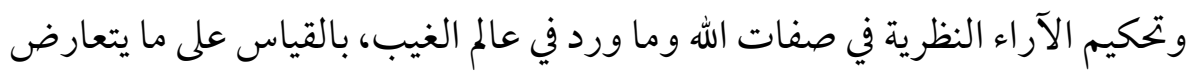

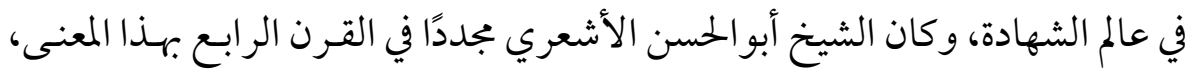

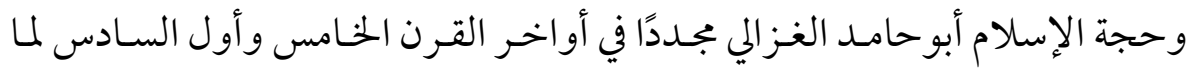

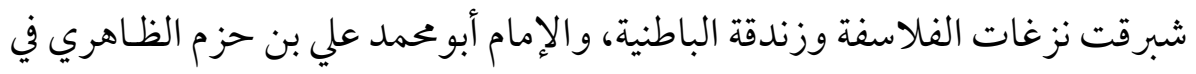

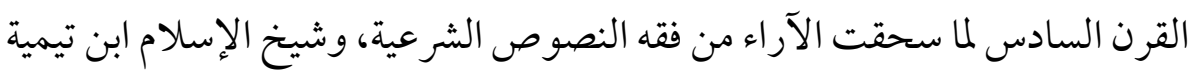

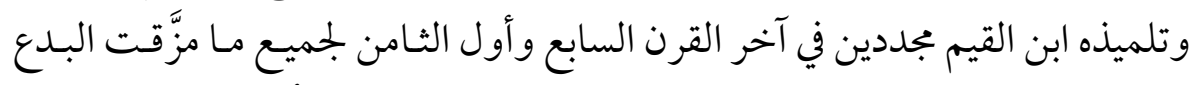

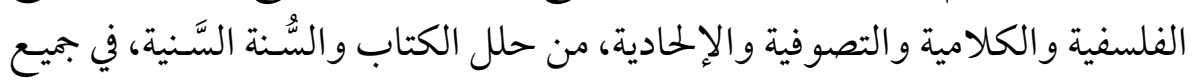

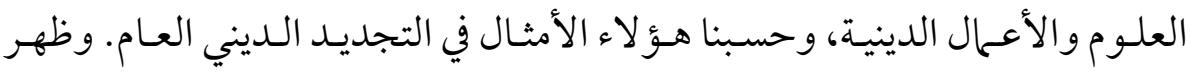

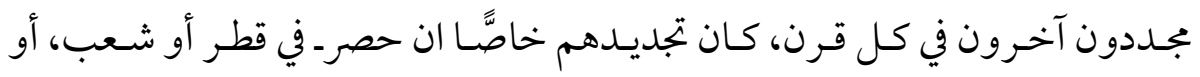

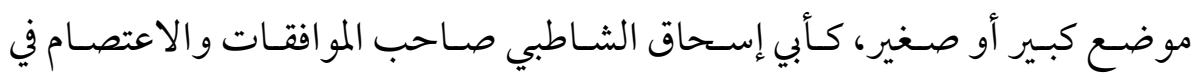

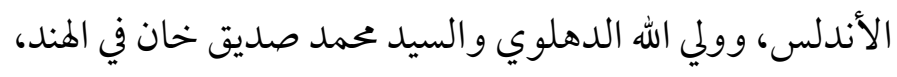
و المولى محمد بن بيرعلي البركوي في الترك، و الشيخ محمد عبدالوهاب في نجد، والمقبلي

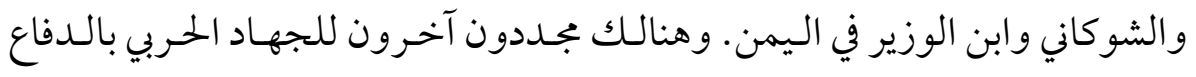
عنالإسلام، أو تجديد ملكه وفتح البلاد له، و إقامة أركان العمران فيه، وهم كثير وني ونفي

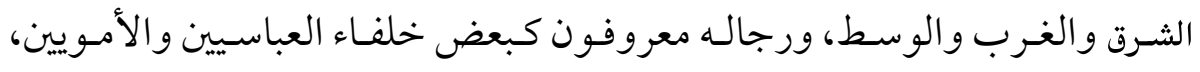

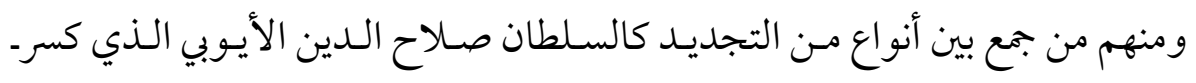


جيـوش الصـيبيين مـن شعوب الإفرنج المتحـدة، وأجلاهـم عـن البلاد الإسـلامية

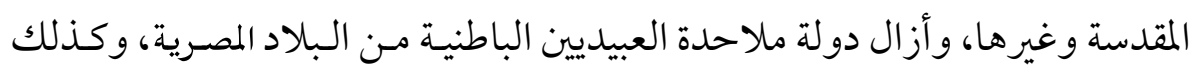

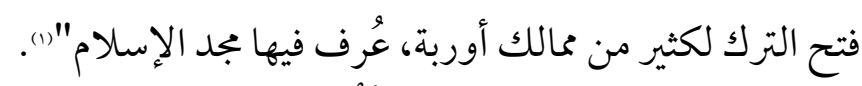

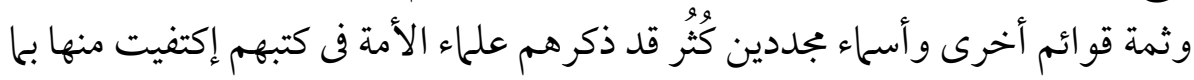
ذُكر إشارة إلى الاعتناء بأعلام الأمة من المجدئ كُدين.

من مشاهير المجددين عبر تاريخ الدولة الاسلامية:

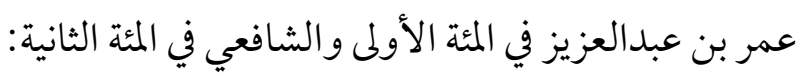

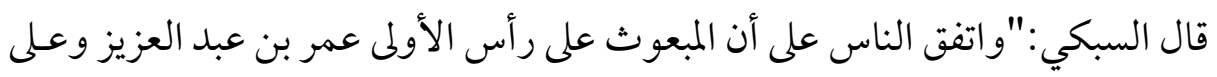

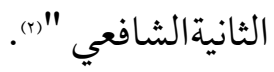

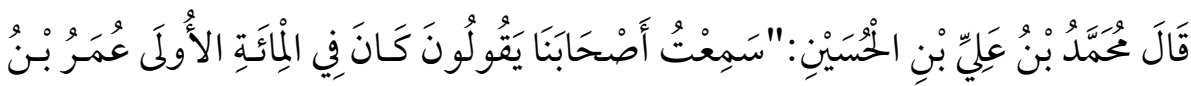

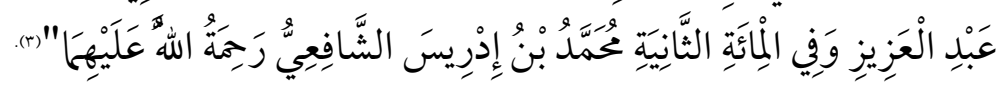

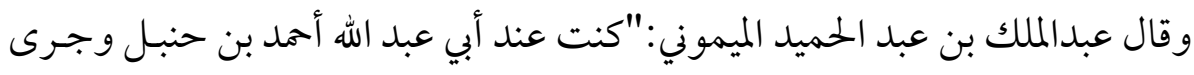

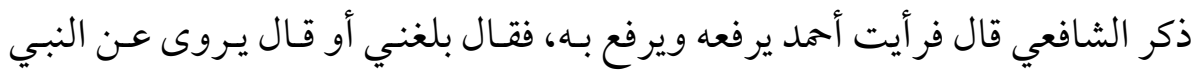

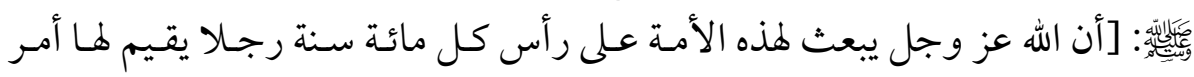

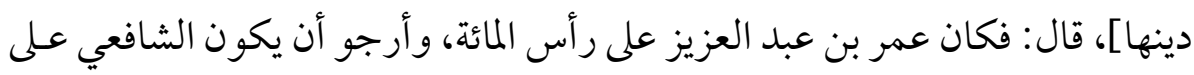

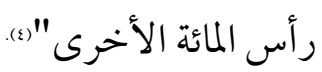

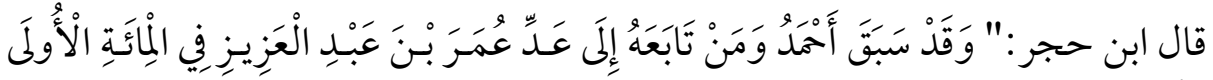

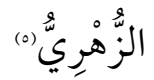

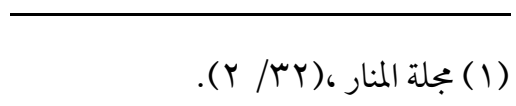

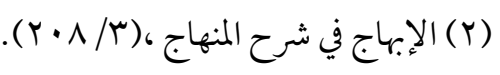

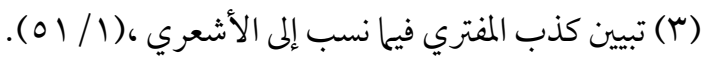

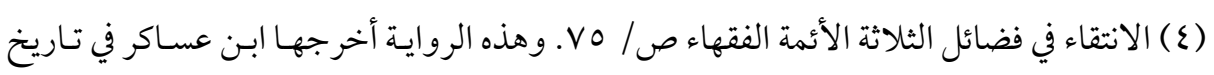

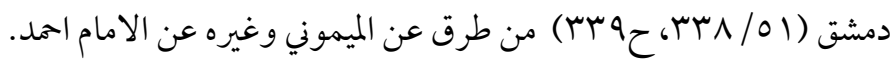

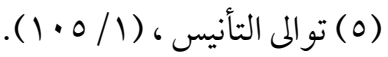




$$
\text { أما عمر بن عبد العزيز }
$$

فالأمر فيه كما قال ابن الأثير :"ويكفي الأمة في هـذه المائة وجوده خاصـة، فإِنه فَعَلَ في

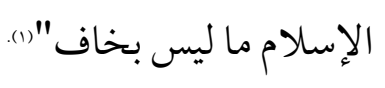

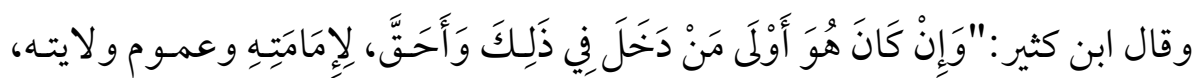

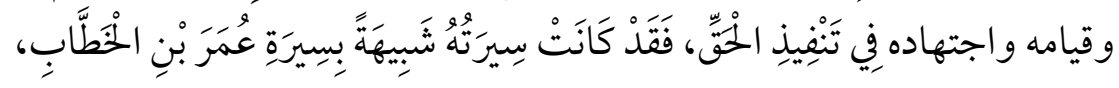

$$
\text { وَكَانَ كَثِيرًا مَا تشبه به" }
$$

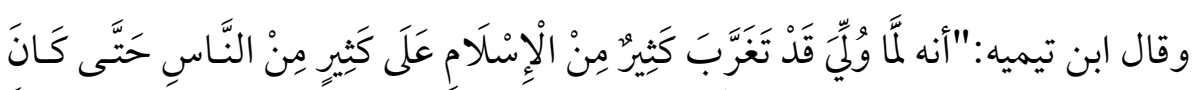

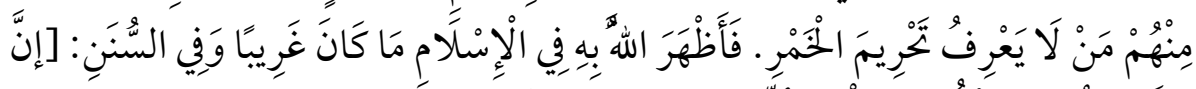

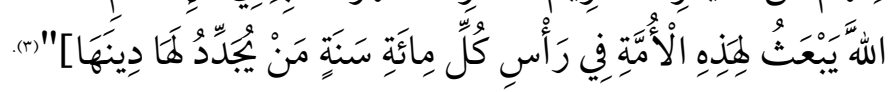

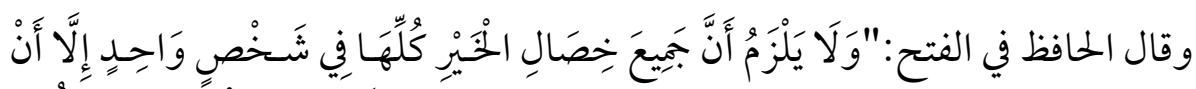

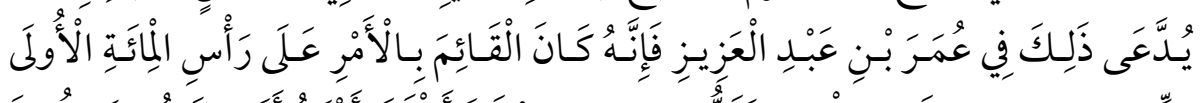

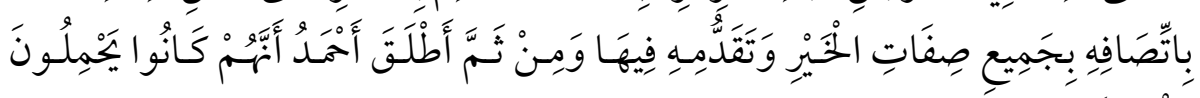

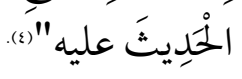
وأما الشافعي:

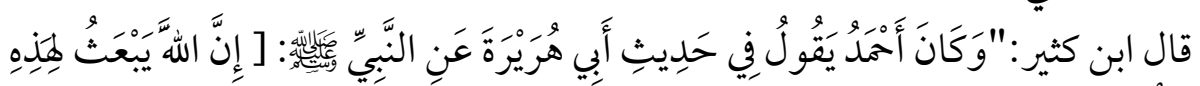

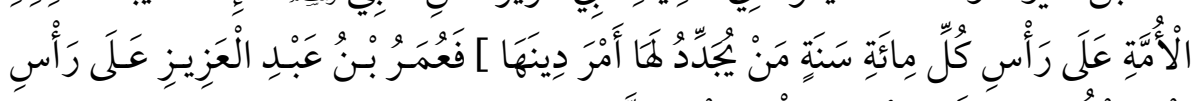

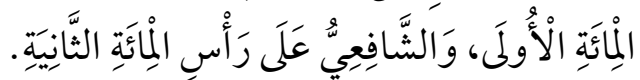

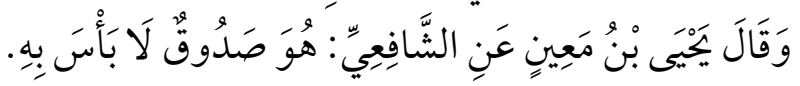

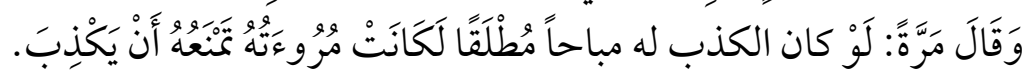

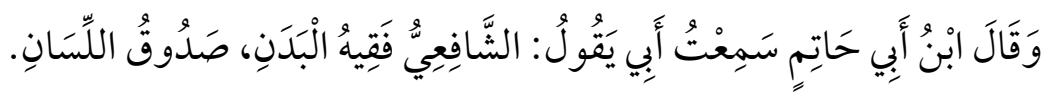

$$
\begin{aligned}
& \text { (1) جامع الاصول، (119/11) (119). }
\end{aligned}
$$

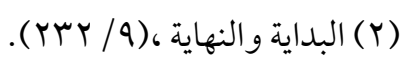

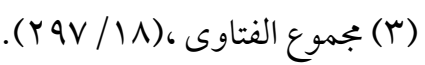

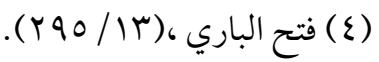




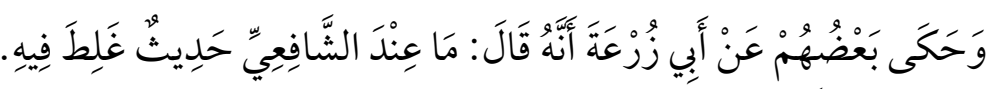

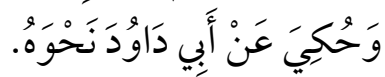

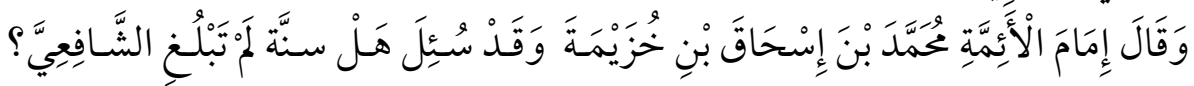
فَقَالَ:لَا،

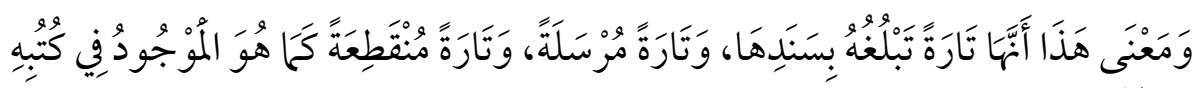

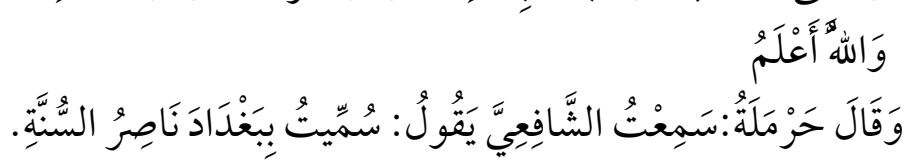

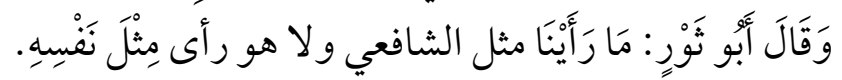

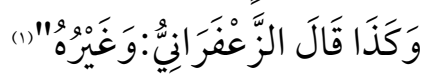




$$
\text { المسيح والمهدى يجددان أمر الدين }
$$

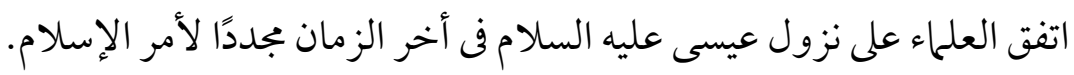

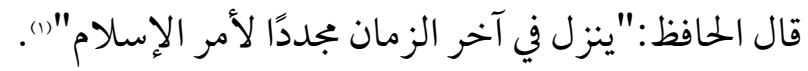

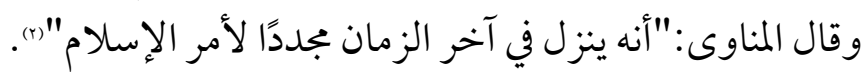

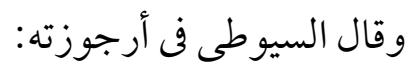

(وَآخر المئين فِيَهَا ياتى .... عِيسَى نبى الله ذُو الْالِيَات)

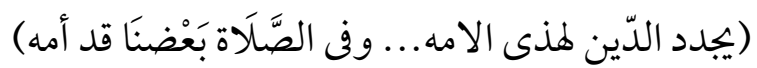

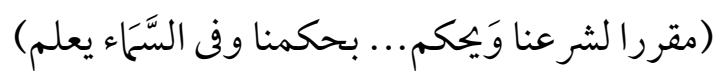

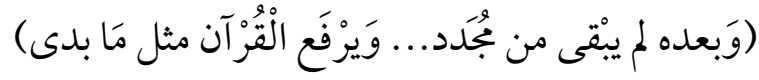

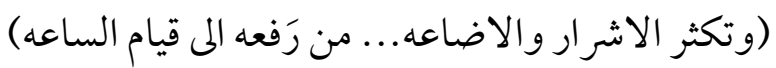

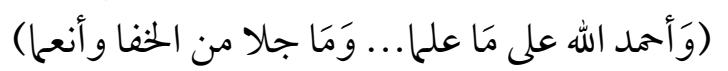

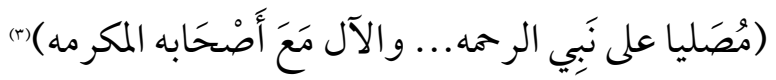

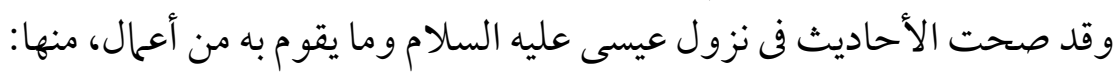

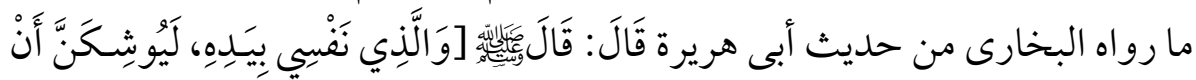

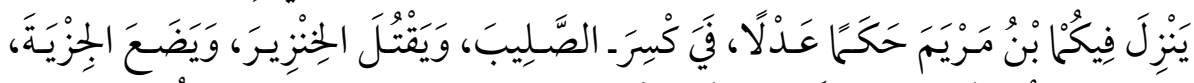

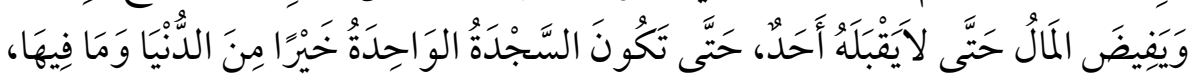

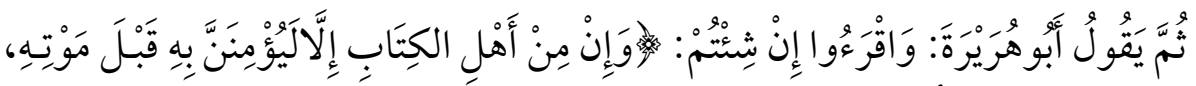

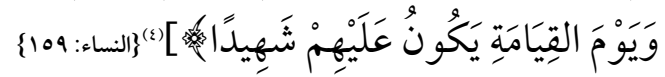

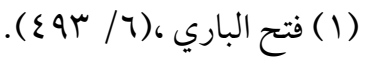

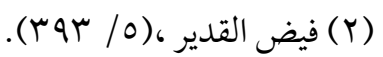

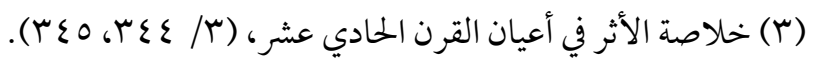

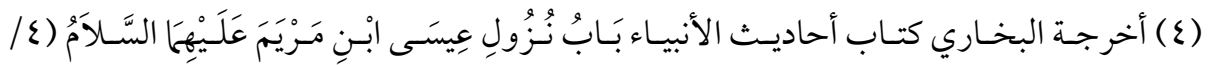

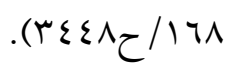




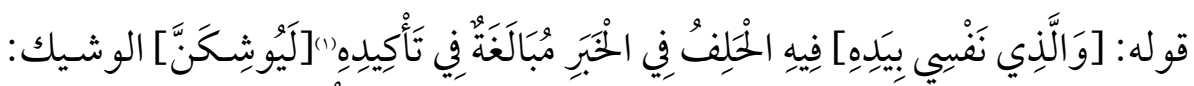

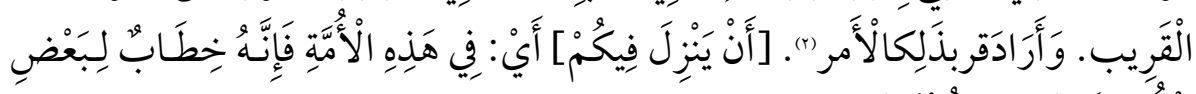

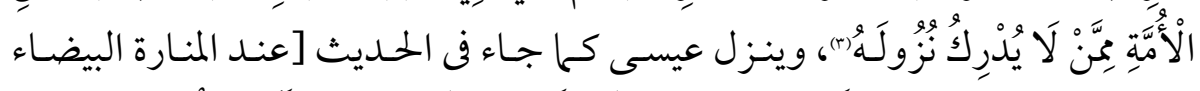

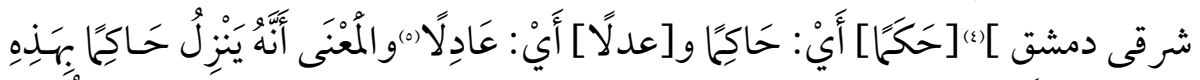

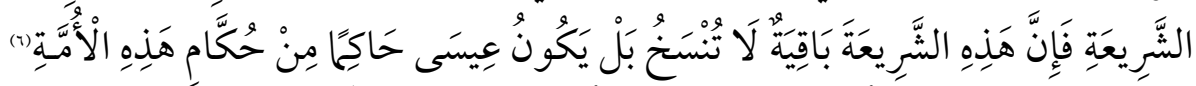

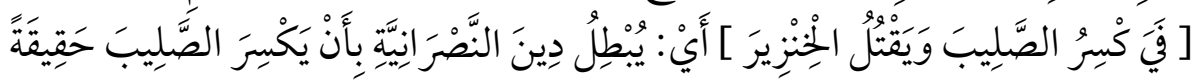

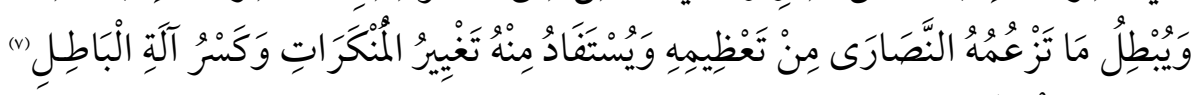

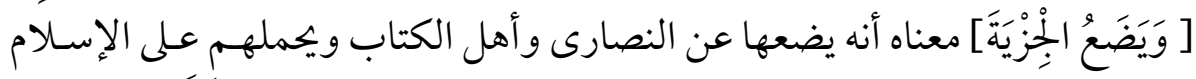

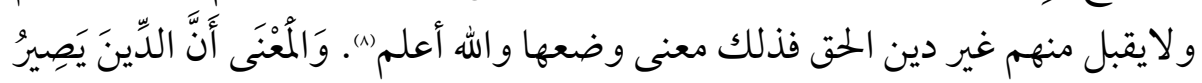

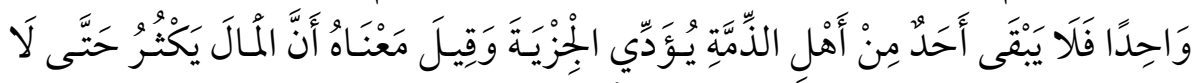

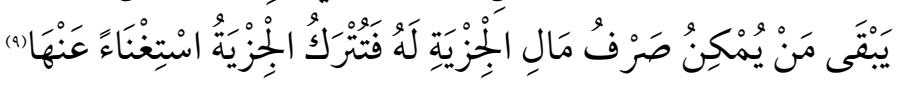

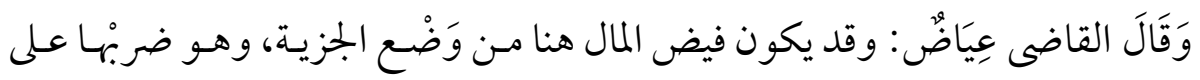

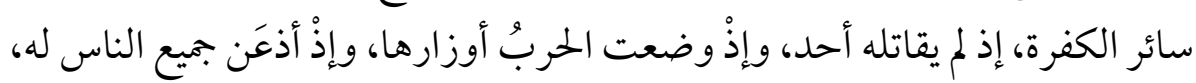

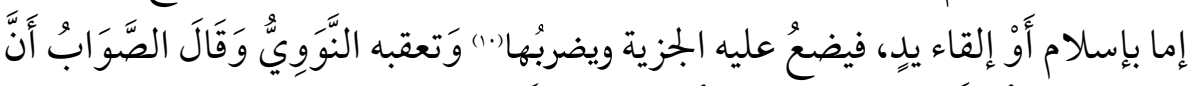

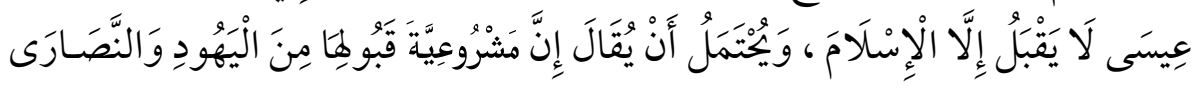

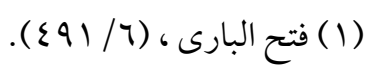

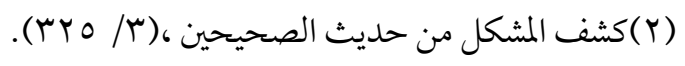

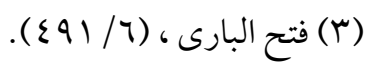

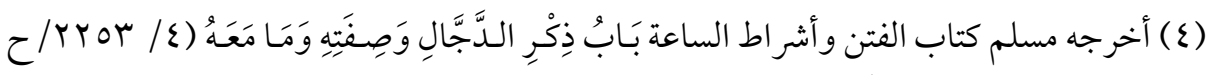

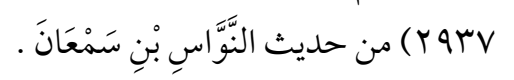

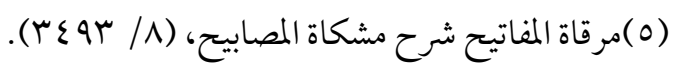

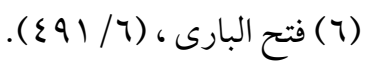

$$
\begin{aligned}
& \text { (V) السابق نفسه. }
\end{aligned}
$$

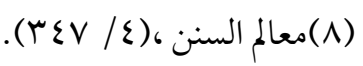

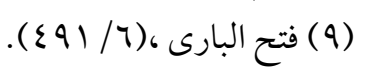

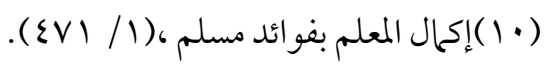




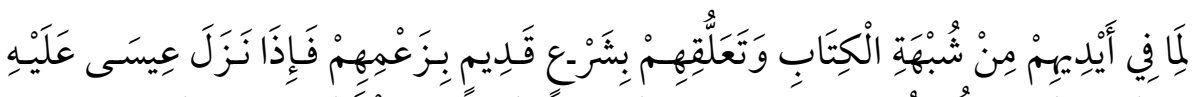

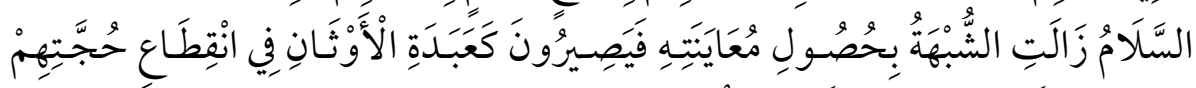

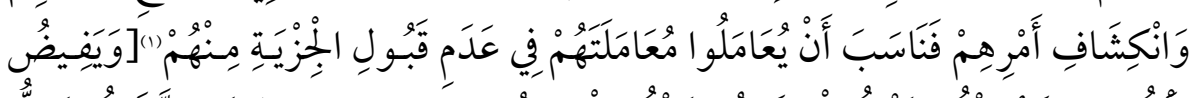

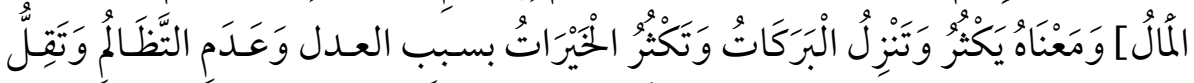

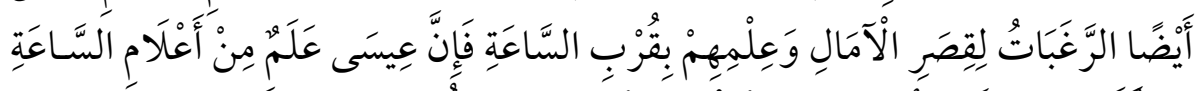

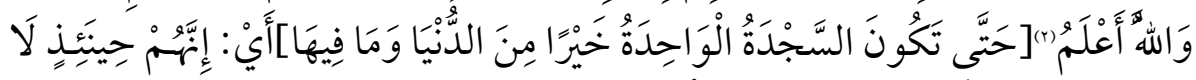

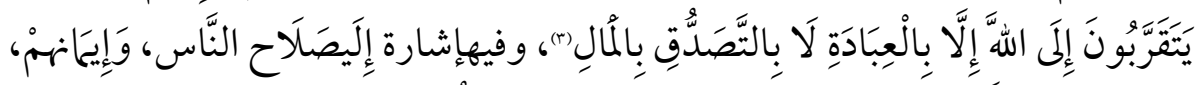

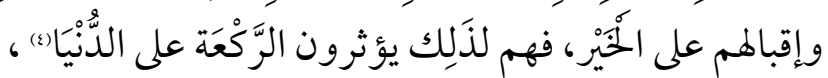

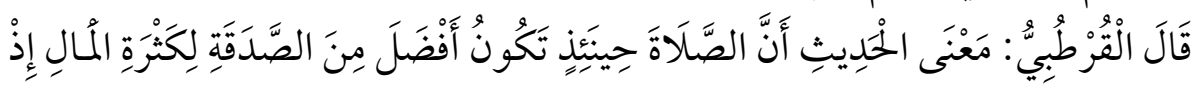

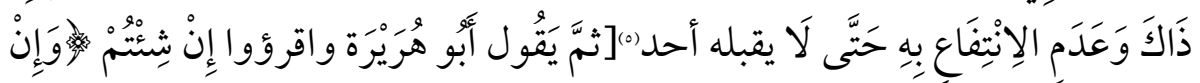

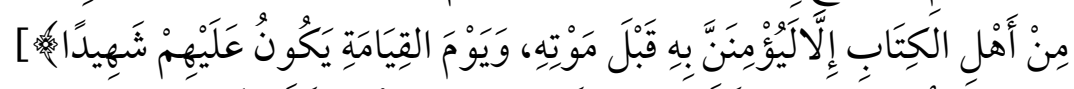

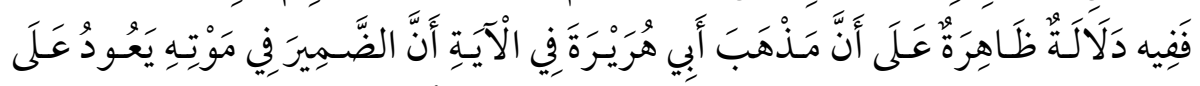

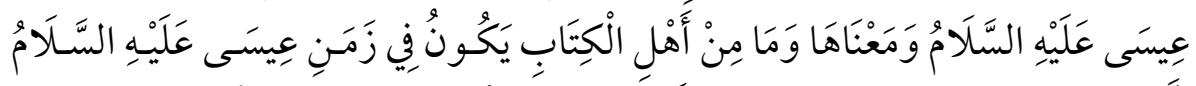

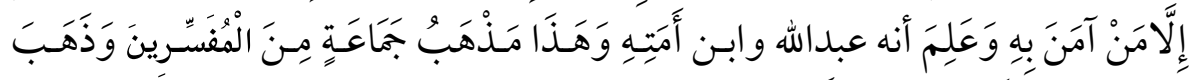

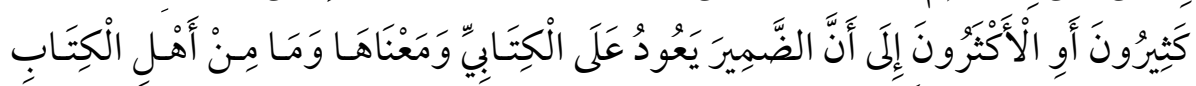

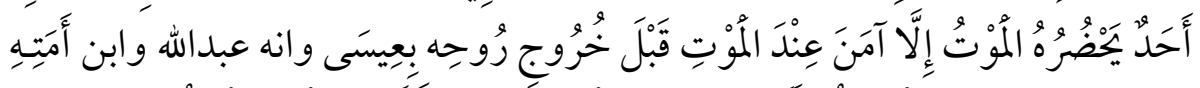

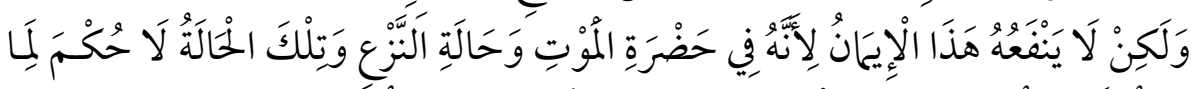

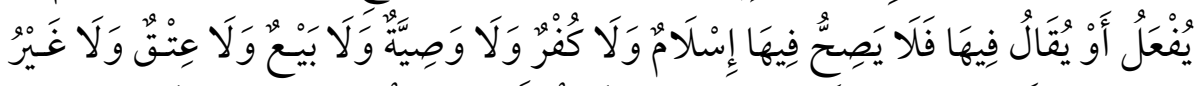

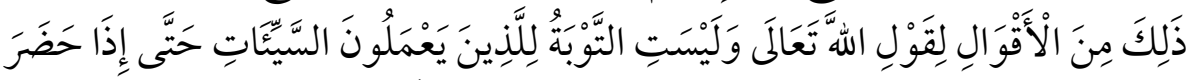

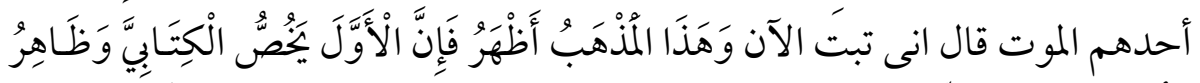

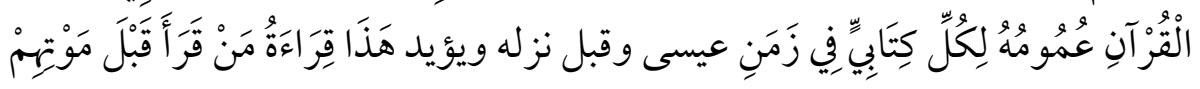

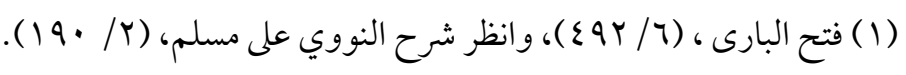

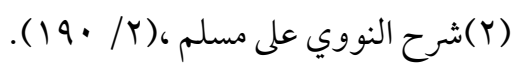

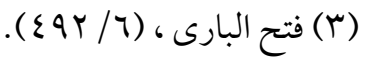

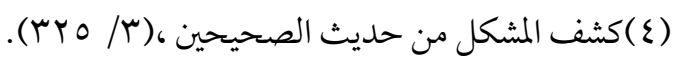

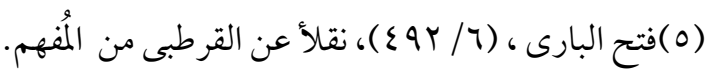

ont 


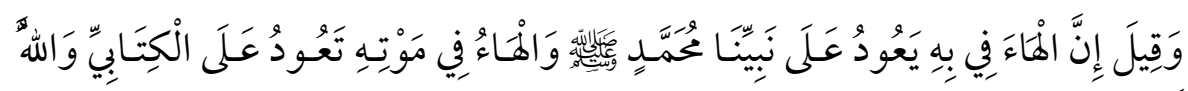
أَعْلَمَ" (1).

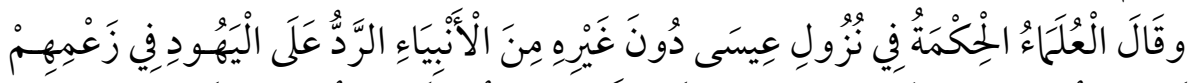

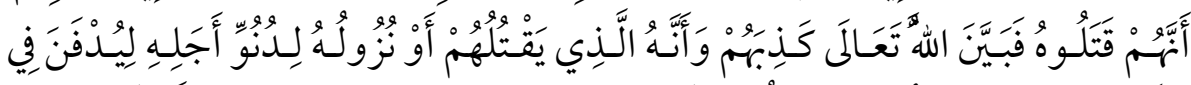

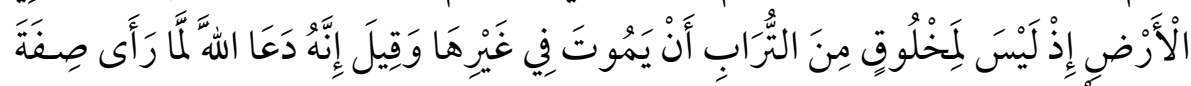

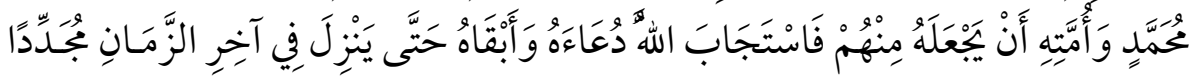

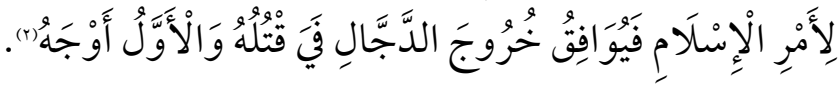

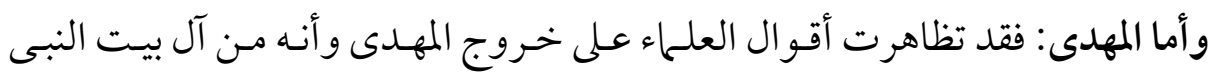
قأِ

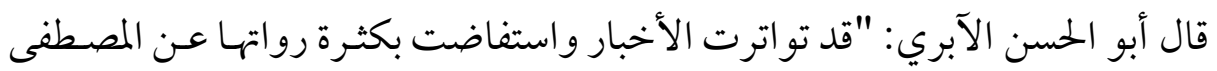

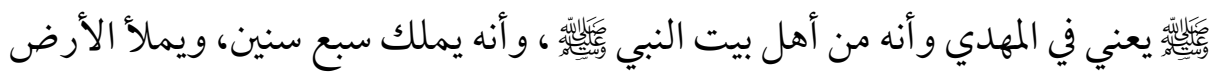

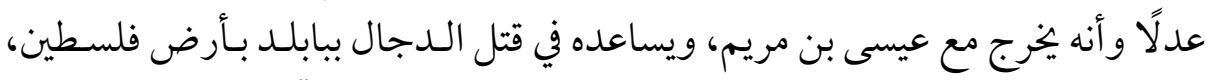

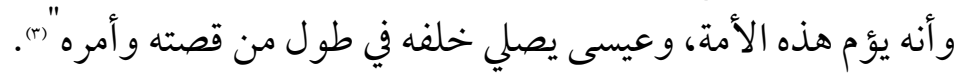

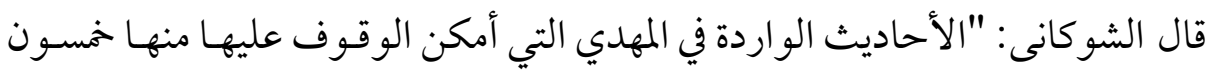

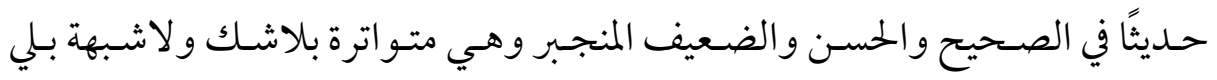

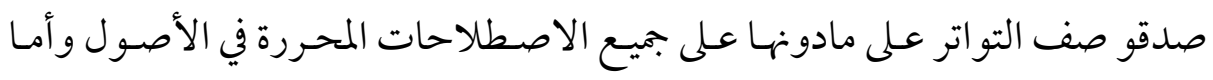

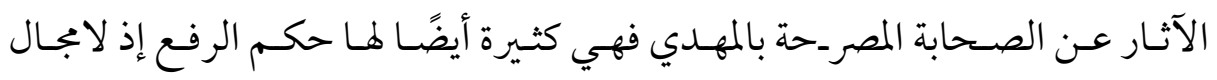

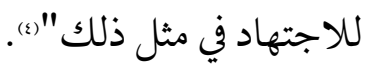

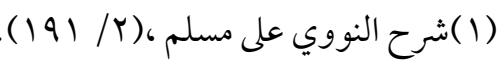

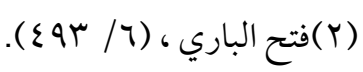

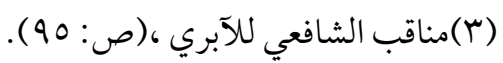

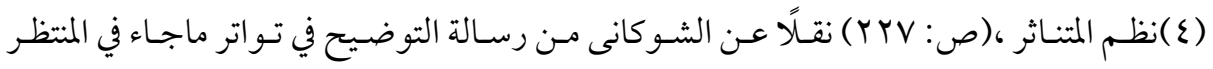

$$
\text { والدجال والمسيح. }
$$


قال الكتانى: "والحاصل أن الأحاديث الو اردة في المهدي المنتظر متواترة وكذا الواردة

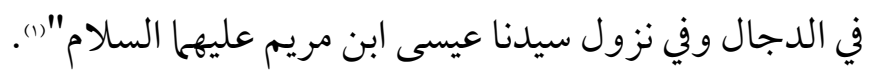

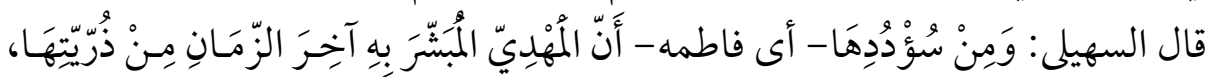

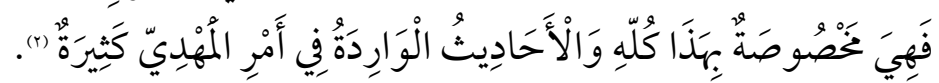

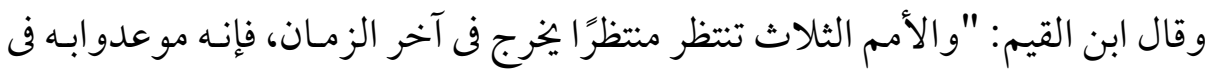
كل ملة.

والمسلمون يتتظرون نزول المسيح عيسى بن مريم مـن السهاء، لكسرـ الصليب، وقتل

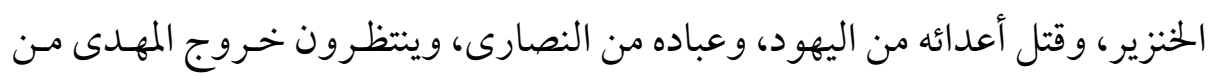

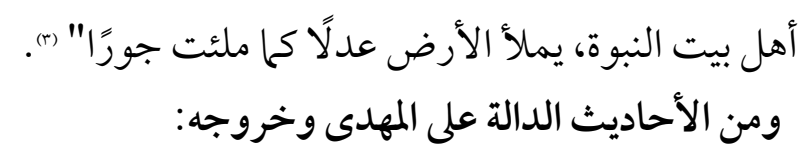

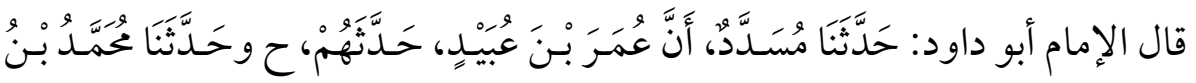

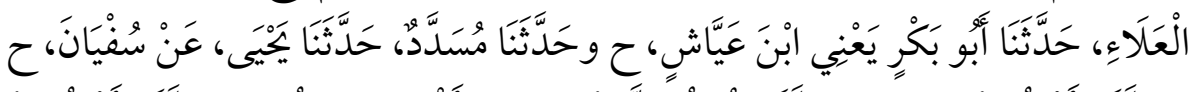

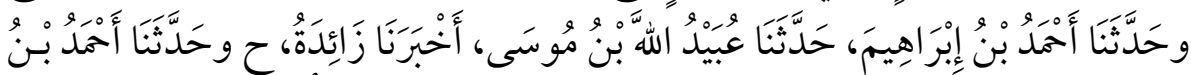

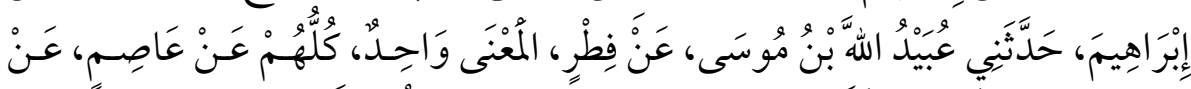

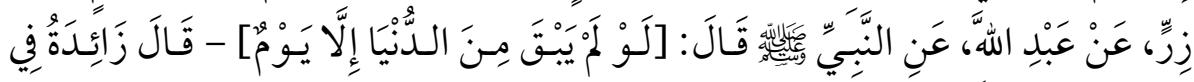

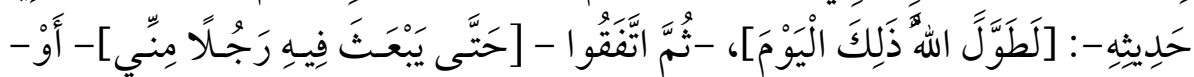

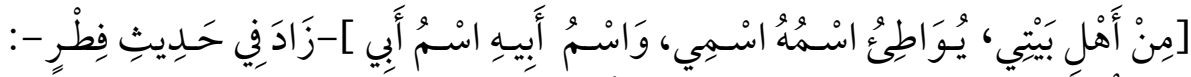

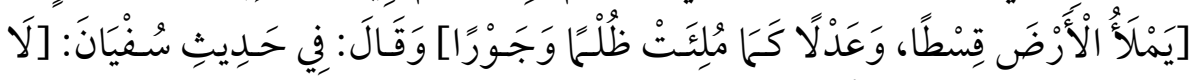

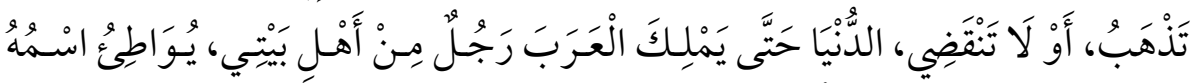

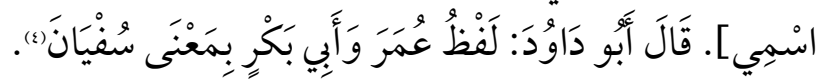

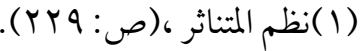

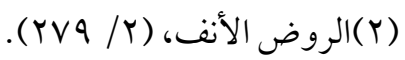

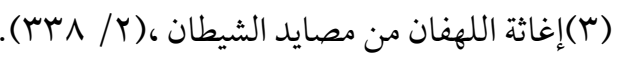

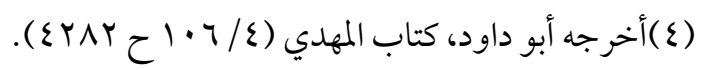

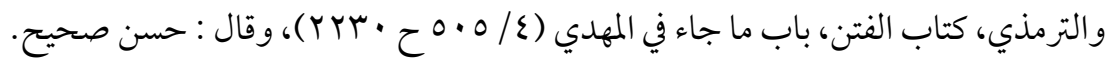

$$
\begin{aligned}
& \text { وأمد (rov) }
\end{aligned}
$$




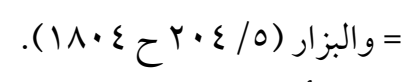

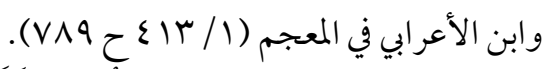

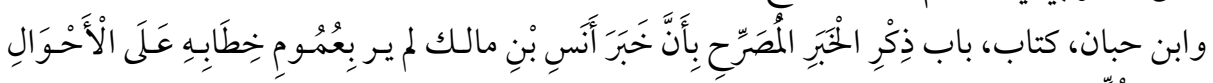

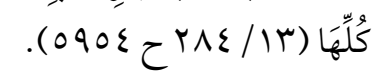

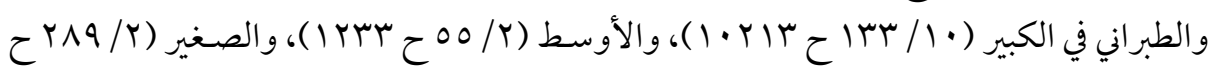

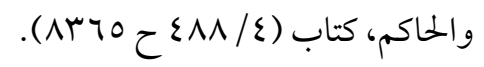

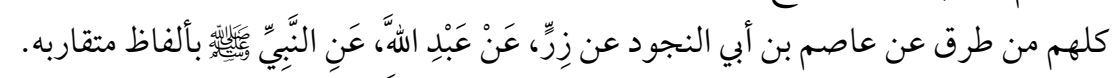

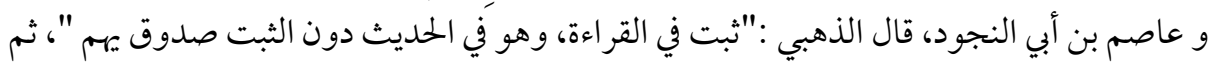

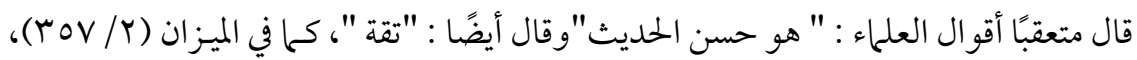

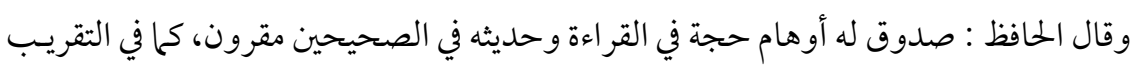
(r^o/1)

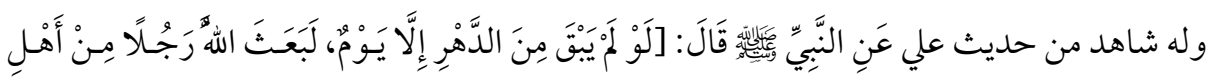

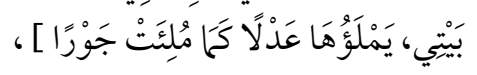

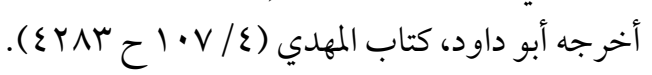

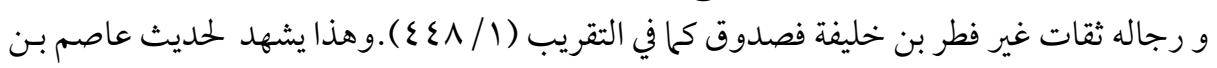

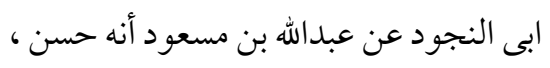

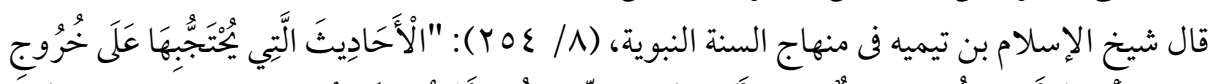

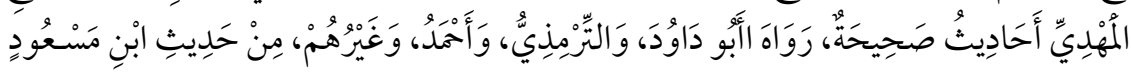

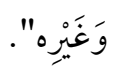

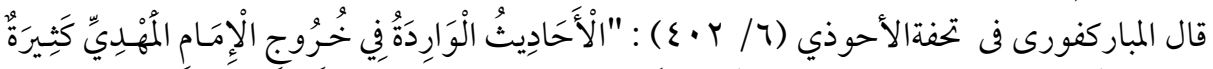

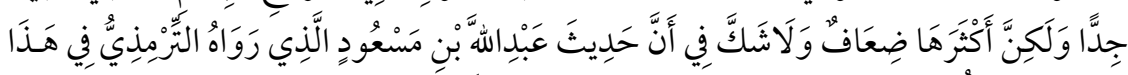

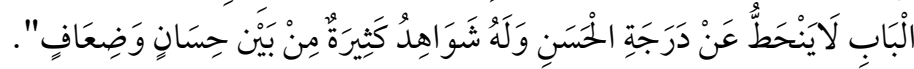

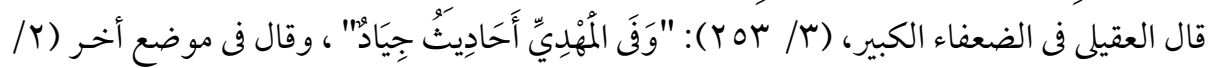

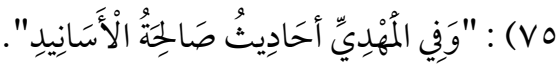

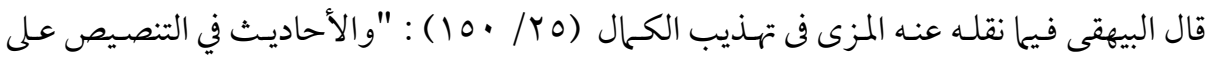

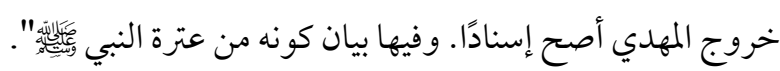

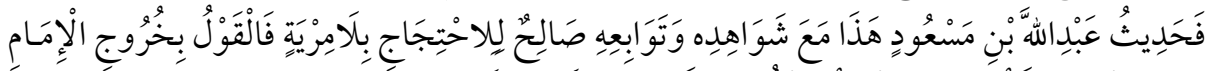

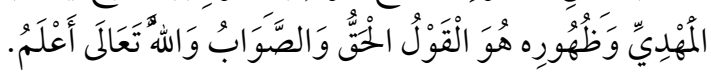

○人。 


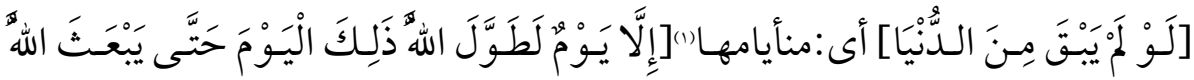

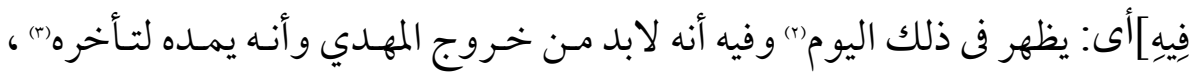

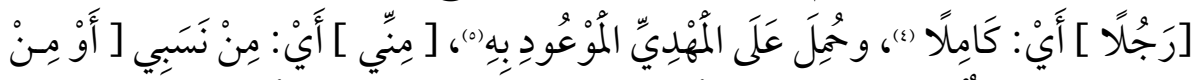

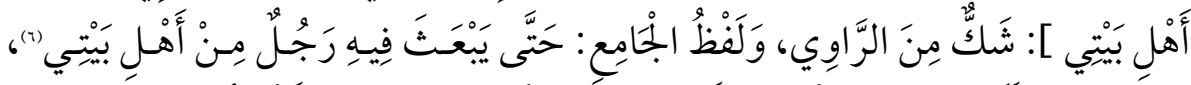

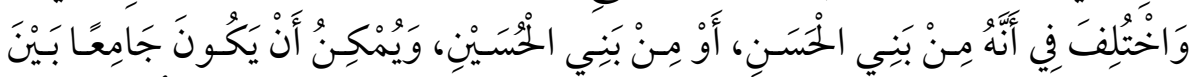

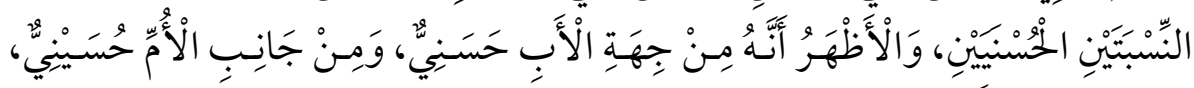

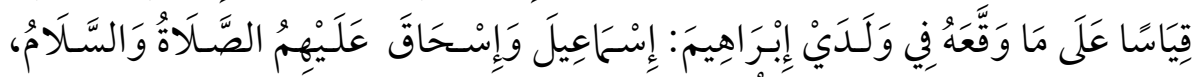

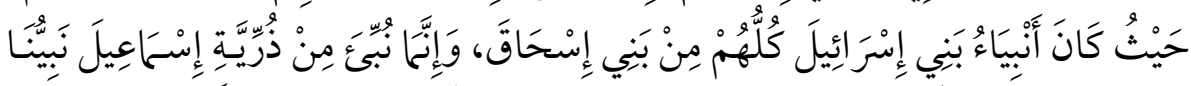

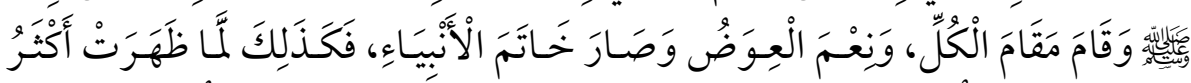

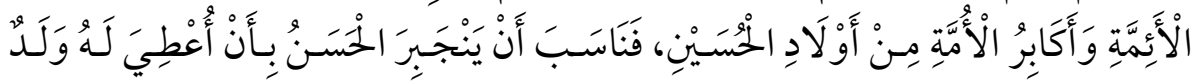

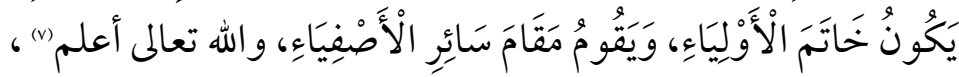

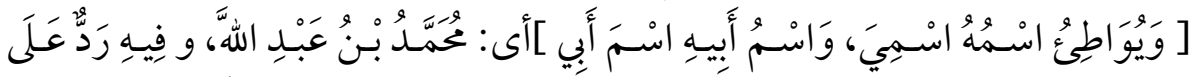

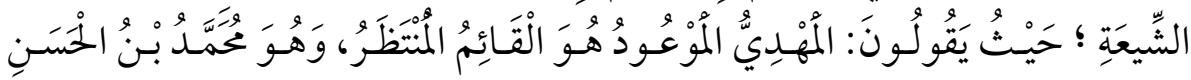

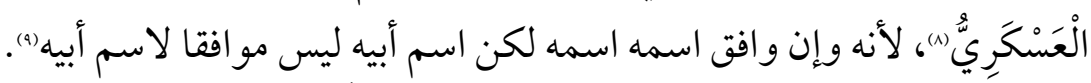

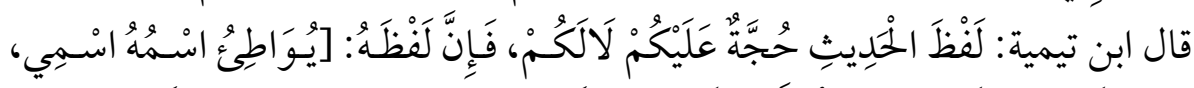

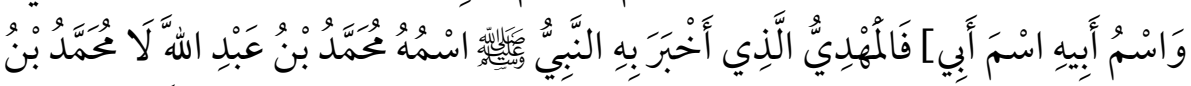

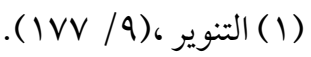

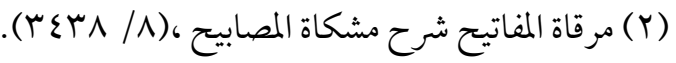

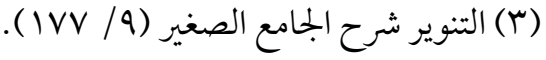

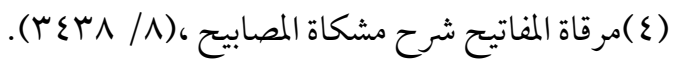

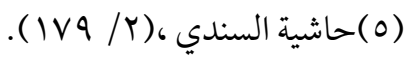

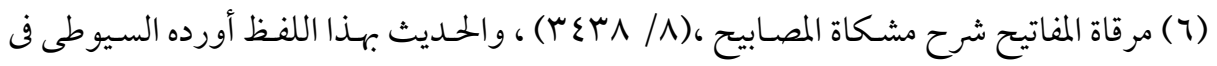

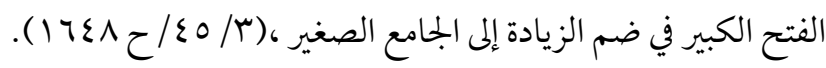

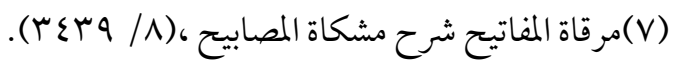
(^) (م) السابق نفسه.

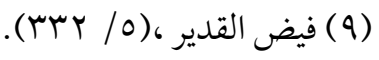


أِ

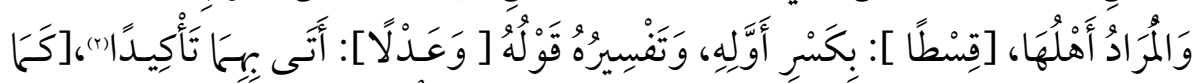

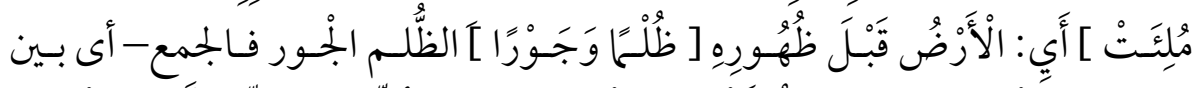

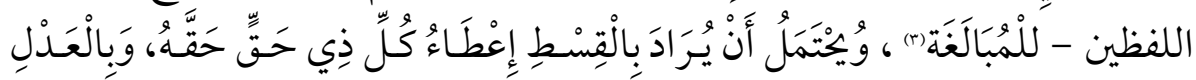

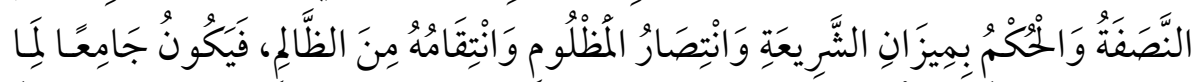

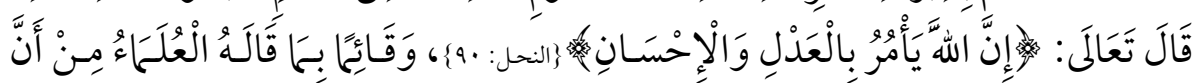

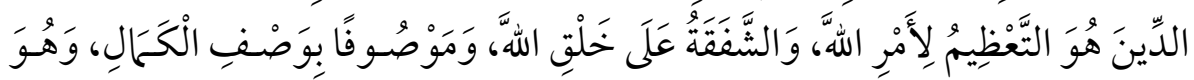

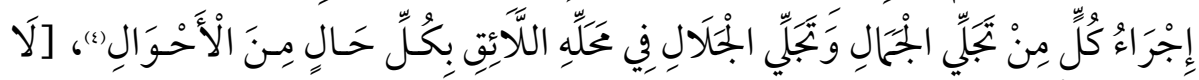

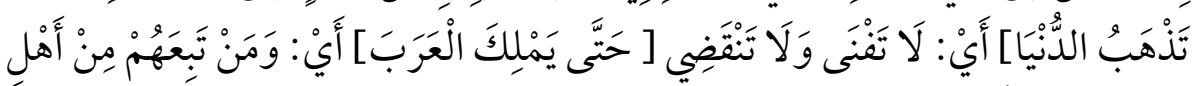

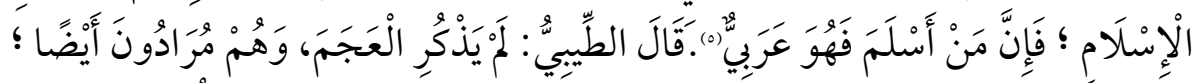

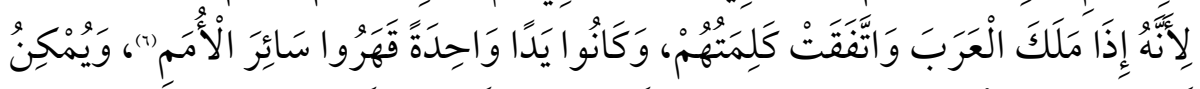

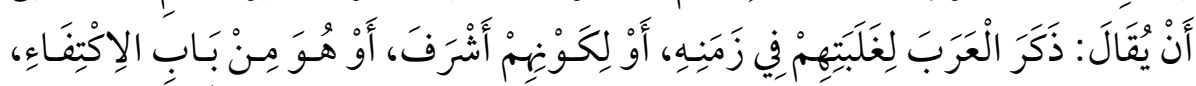

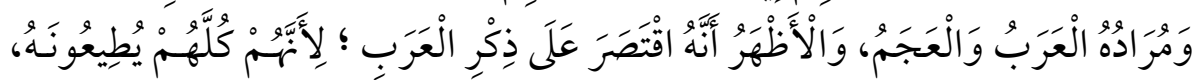

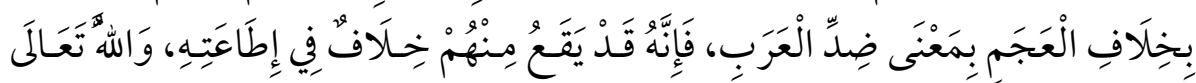

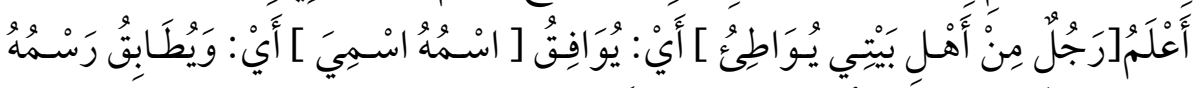

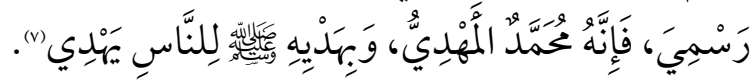

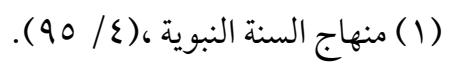

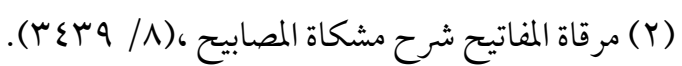

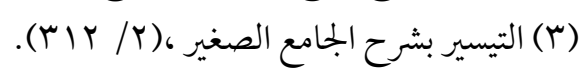

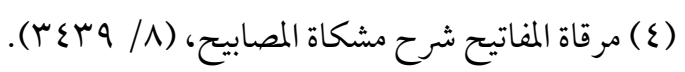

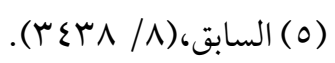

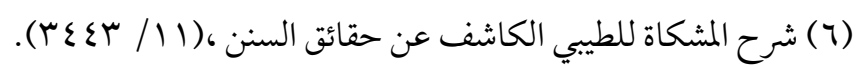

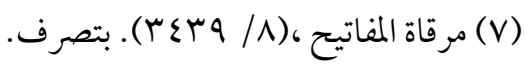




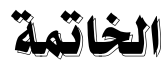

$$
\text { نتائج الدراسة وثثارها: }
$$

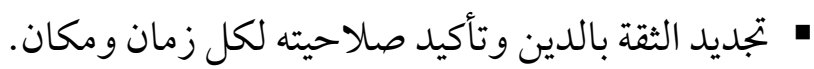

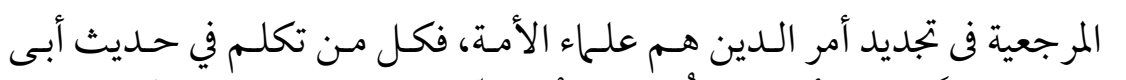

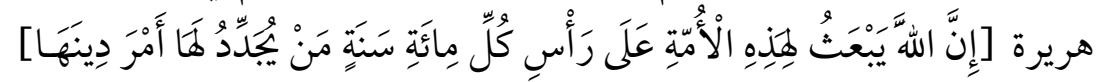

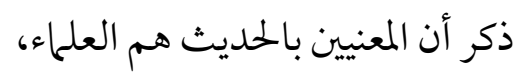

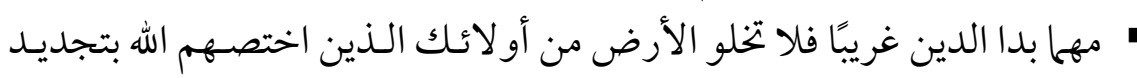

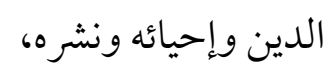

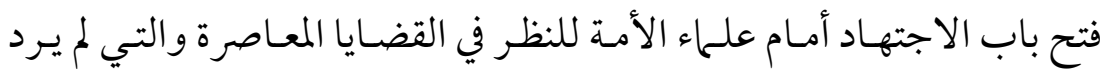

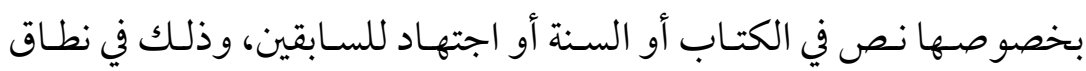

$$
\text { الثوابت بعيدا عن الجمود و الشطط. }
$$

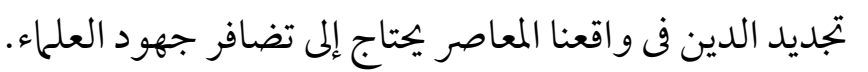

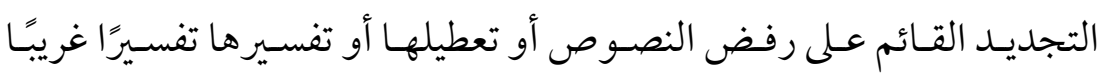

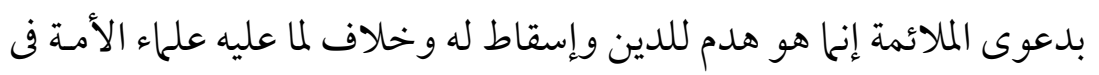

$$
\text { معنى التجديد. }
$$

" بطلان زعم القائلين أن العودة إلى الدين عودة إلى الوراء، وإثبات أنهاعودة إلى الثاد

$$
\text { الأصل الذي به يتحقق صلاح الأمة. }
$$

و بعد ، فما كان في هذا البحث من سداد وتوفيق فهو من عون ربى، وما كان فيها

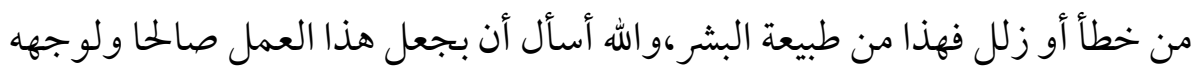

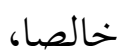




\title{
فهربست المصادروالئراجيع
}

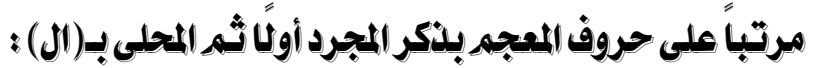

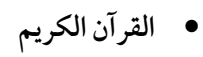

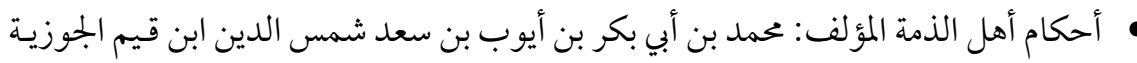

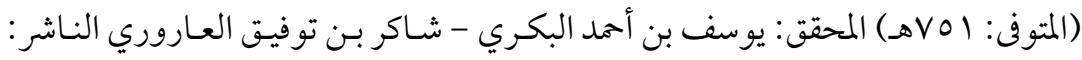

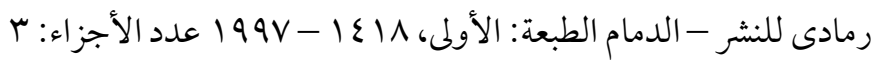

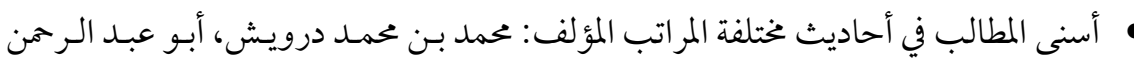

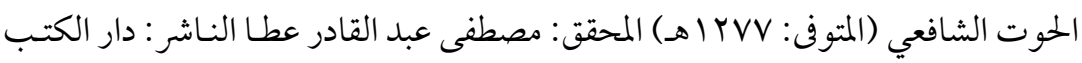

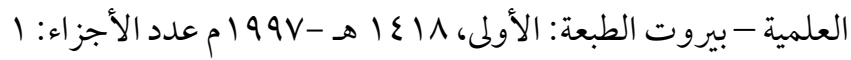

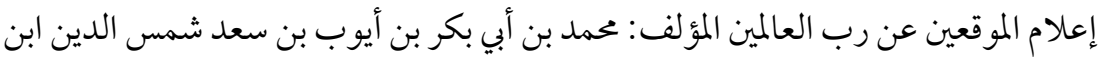

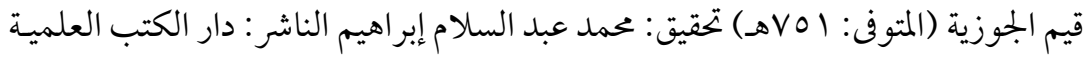

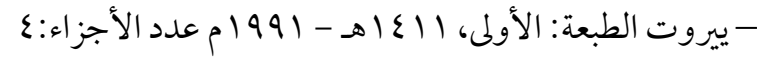

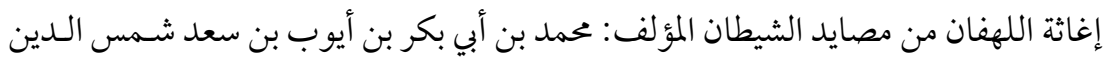

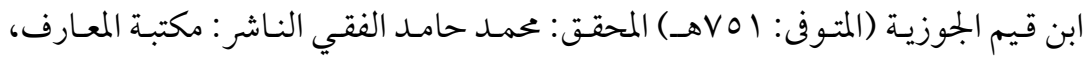

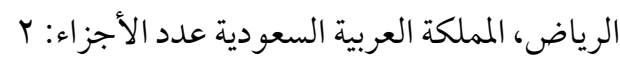

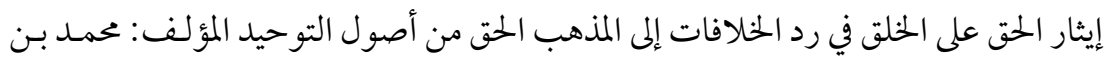

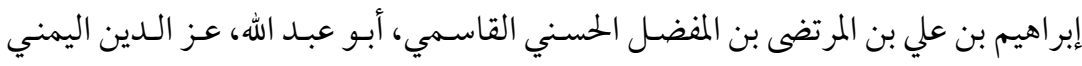

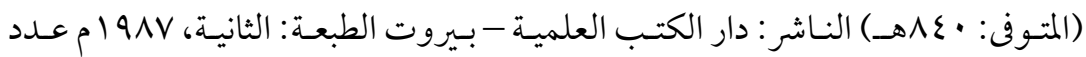 \\ الأجزاء: \\ خلاصة الأثر في أعيان القرن الحادي عشر المؤلف: محمد أمين بن فضل الله بن محب الدين بن \\ محمد المحبي الحموي الأصل، الدمشقي (المتوفى:

$$
\text { عدد الأجزاء: ع ع المجيج الحموي }
$$

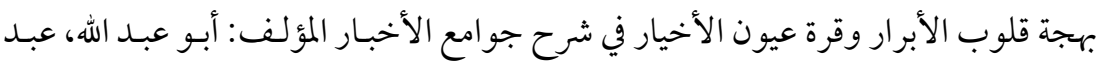

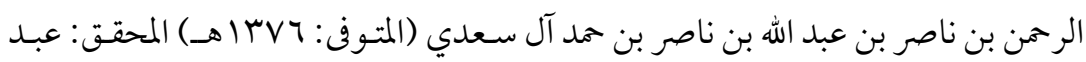

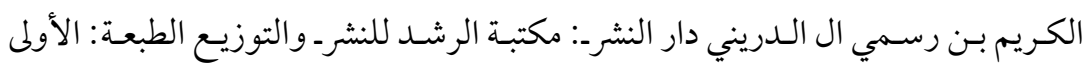 \\ مY
}


بيان الوهم والإيهام في كتاب الأحكام المؤلف: علي بن محمد بن عبد الملك الكتامي الحمـيري

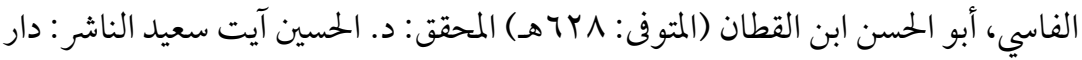

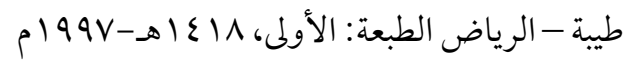

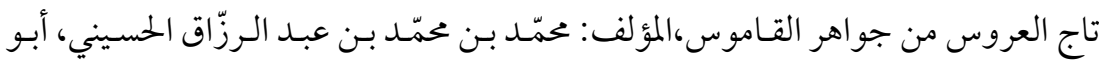

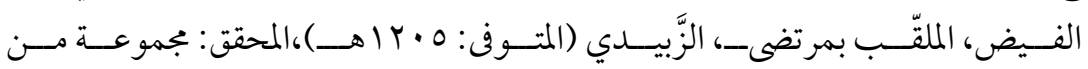
المحققين،الناشر : دار الهداية

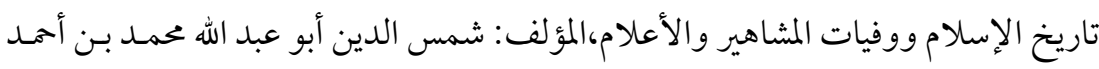

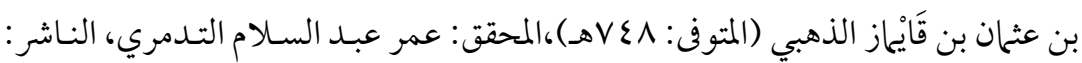

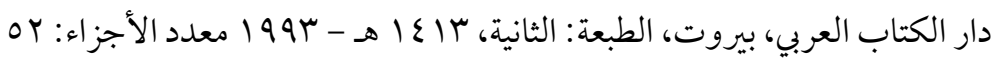

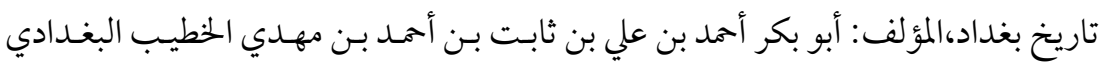

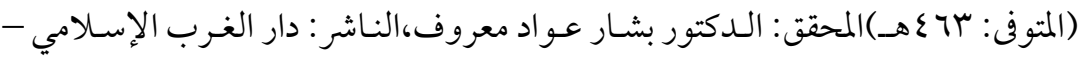

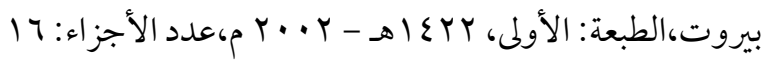

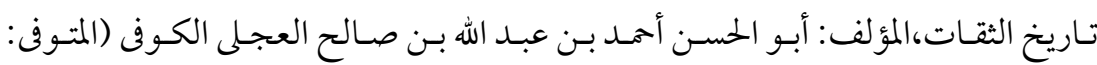

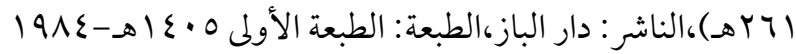

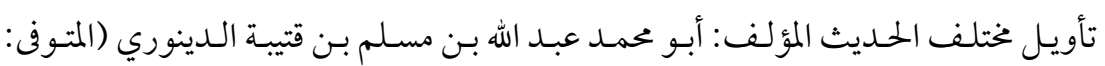

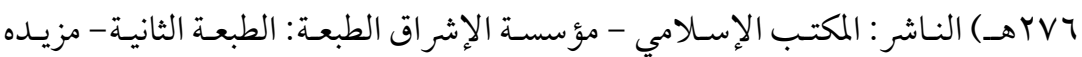

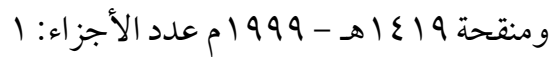

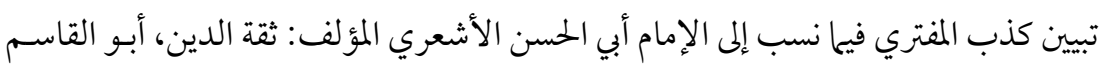

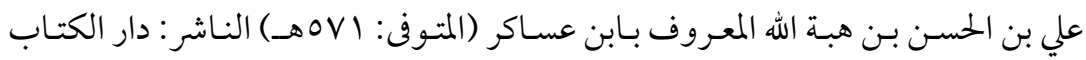

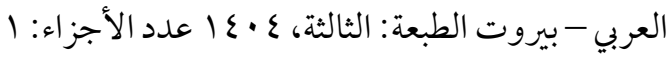

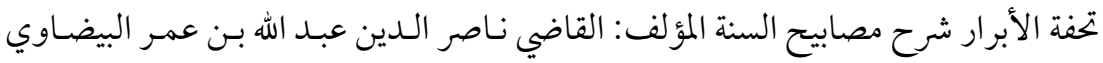

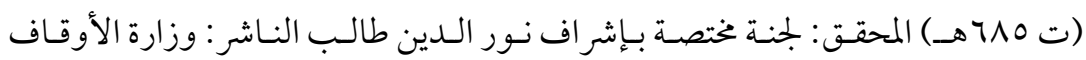

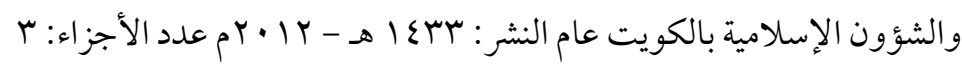

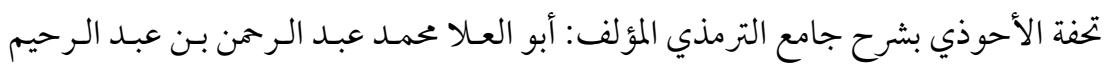

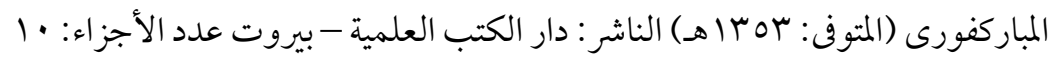

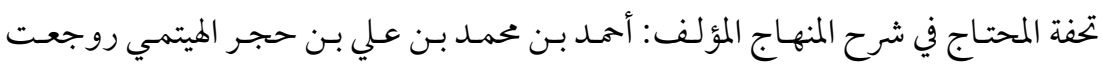

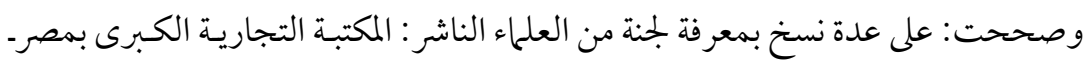

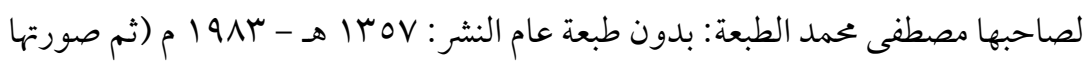
دار إحياء التراث العربي - بيروت، بدون طبعة وبدون تاريخ) عدد الأجزاء: • 


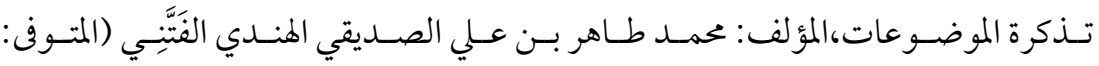

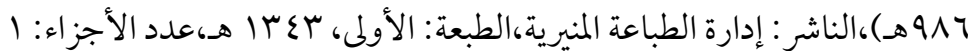

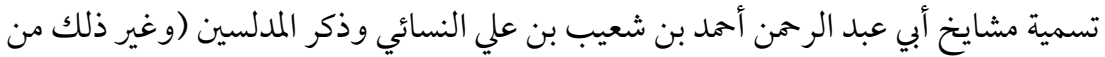

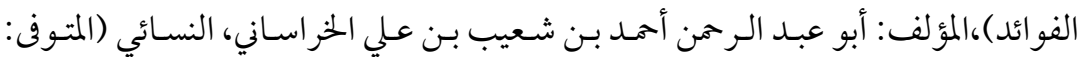

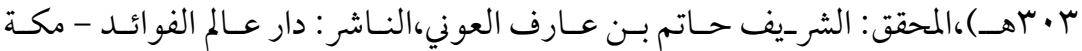

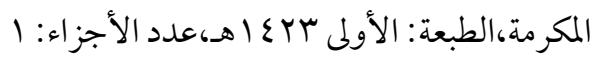

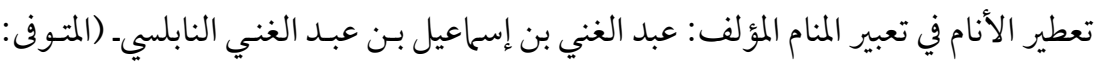

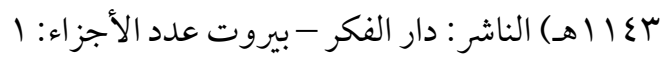

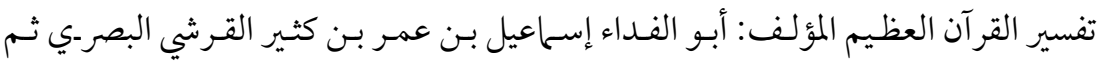

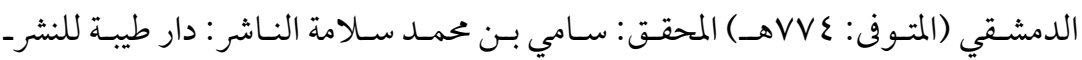

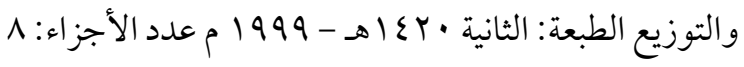

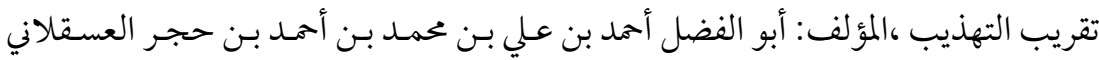

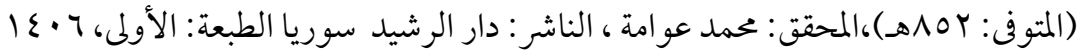

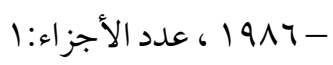

تقرير الاستناد في تفسير الاجتهاد المؤلف: عبد الرحمن بـن أبي بكر، جـلال الدين السيوطي

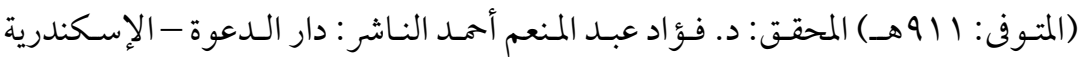

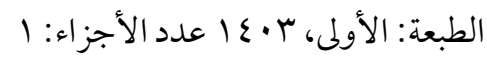

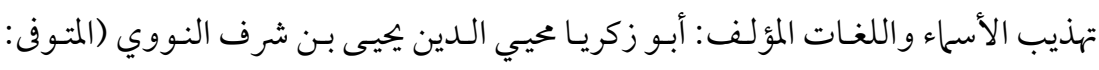

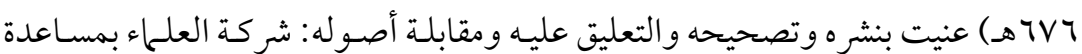

إدارة الطباعة المنيرية يطلب من: دار الكتب العلمية، بيروت - لبنان عدد الأجزاء: ع

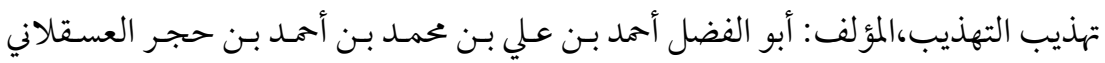

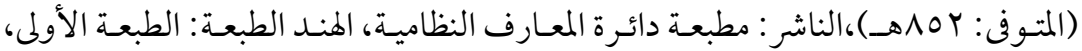

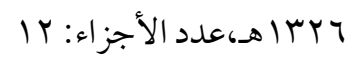

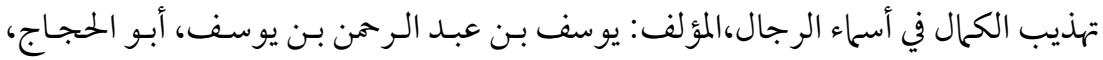

جمال الدين ابن الزكي أبي محمد القضاعي الكلبي المزي (المتوفى: Y ع لهـ)

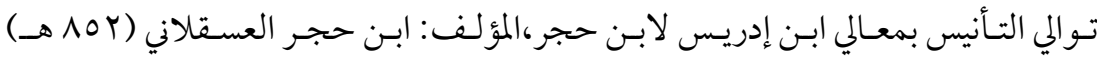

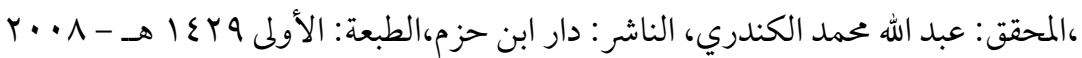

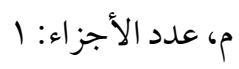

091 


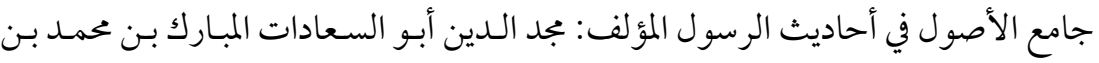

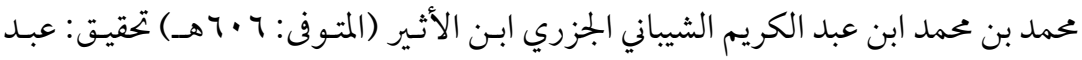

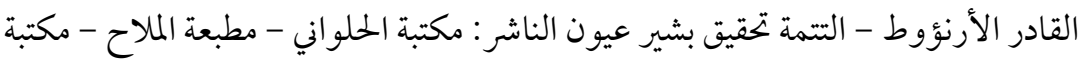
دار البيان الطبعة: الأولى الدرون

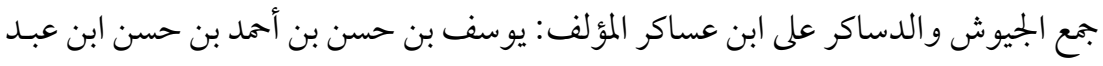

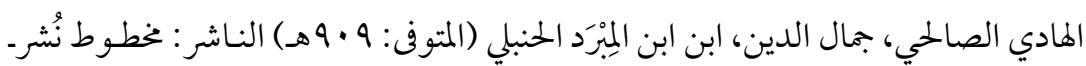

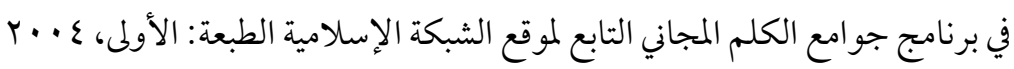

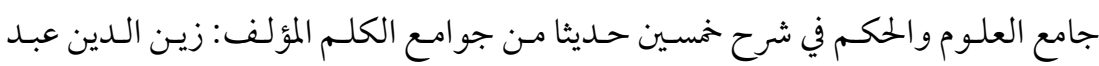

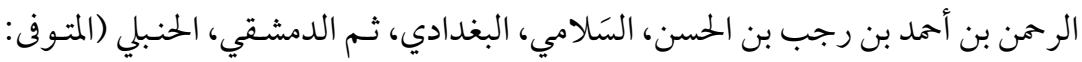

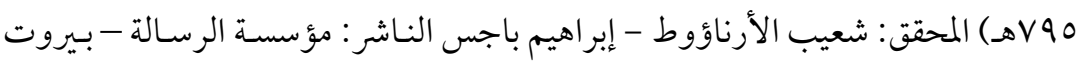

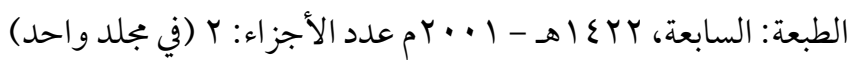

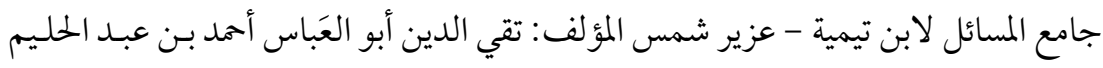

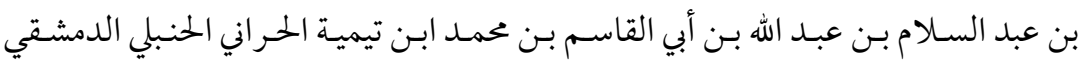

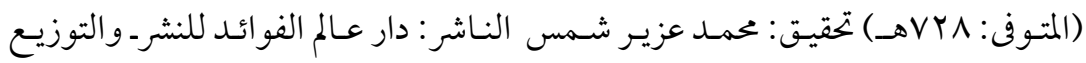

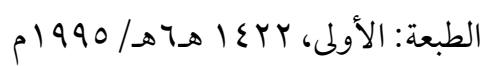

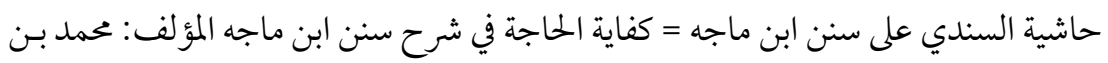

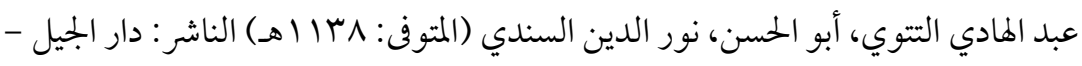
بيروت، بدون طبعة

حلية الأولياء وطبقات الأصفياء المؤلف: أبو نعيم أحمد بن عبد الله بـن أحمد بـن إسـحاق بـن

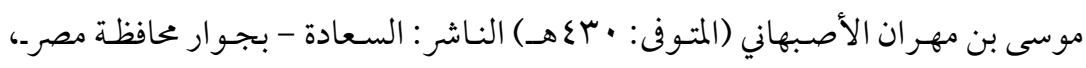

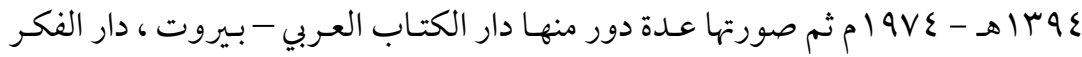

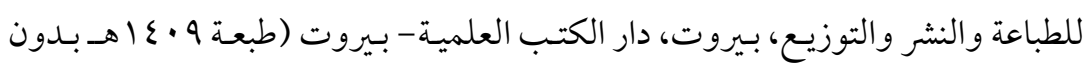

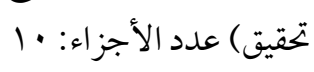
دليل الفالحين لطرق رياض الصدالحين المؤلف: محمـد علي بـن محمد بـن عـالان بـن إبر اهيم

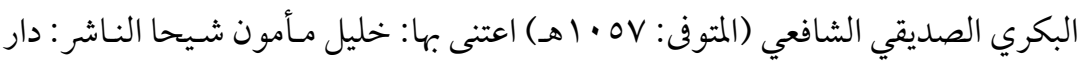

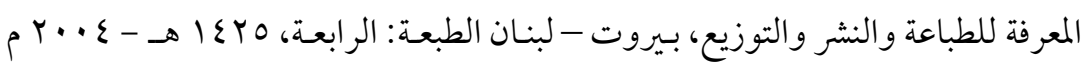

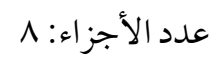


ذم الكلام وأهله المؤلف: أبو إسماعيل عبد الله بن محمد بن علي الأنصـاري الهروي (المتوفى:

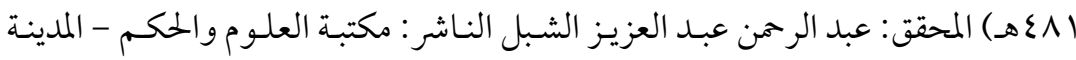

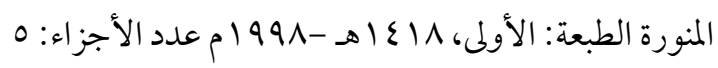

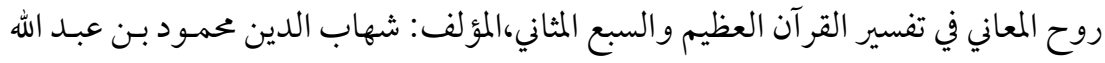

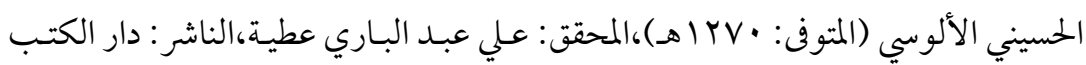

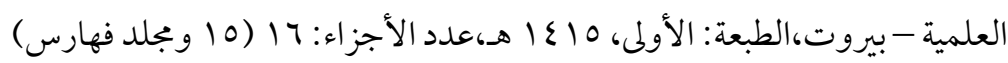

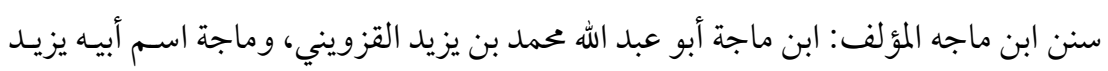

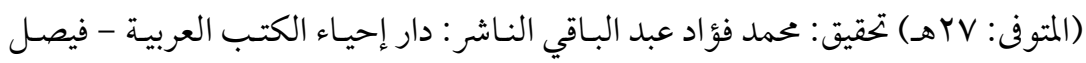

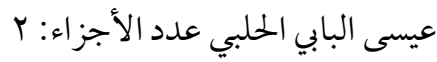

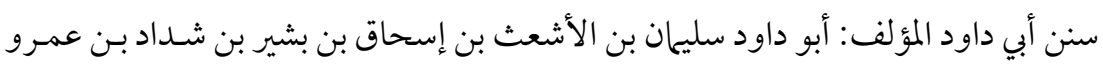

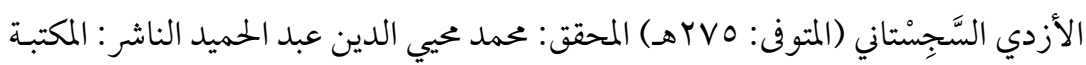

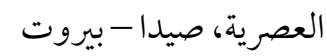

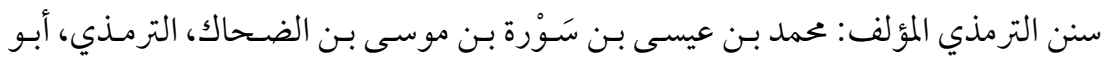

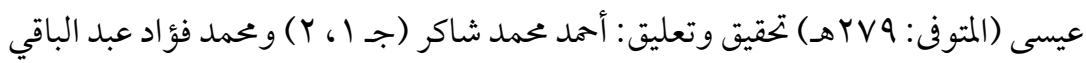

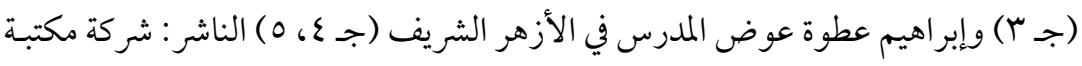

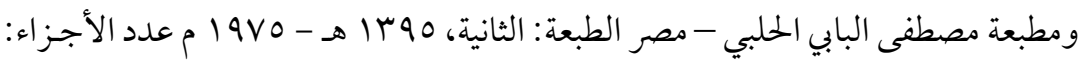
0 سير أعلام النبلاء المؤلف: شمس الدين أبو عبد الله محمد بن أحمد بن عثمان بن قَأيماز الذهبي

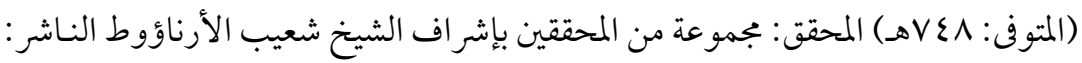

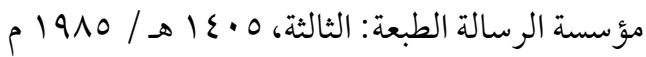

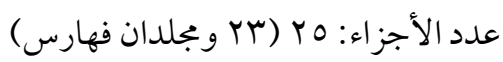
شرح أصول اعتقاد أهل السنة والجماعة المؤلف: أبو القاسـم هبـة الله بـن الحسـن بـن منصـور

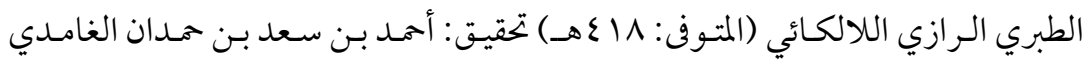

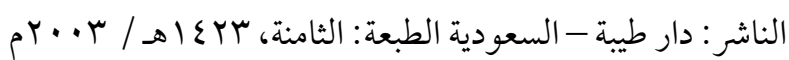

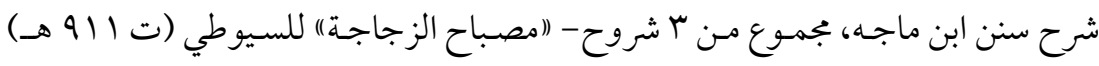

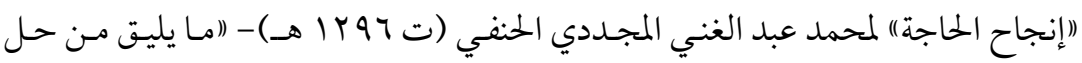

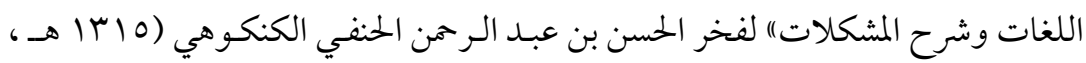

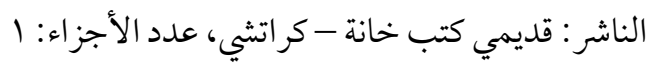




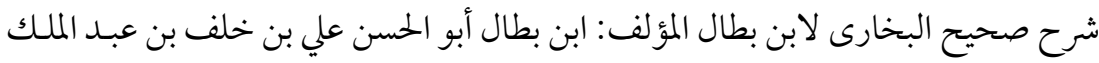

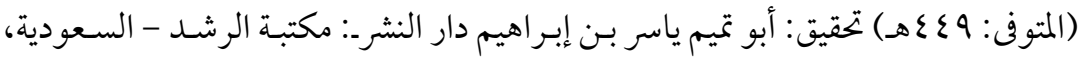

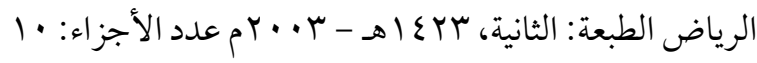

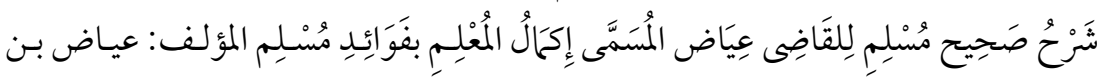

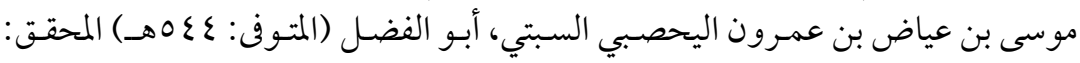

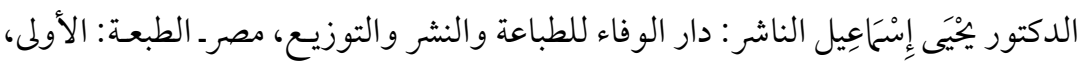

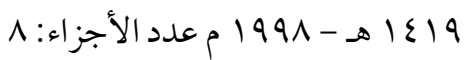

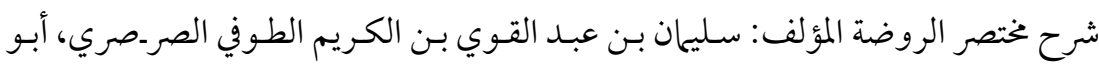

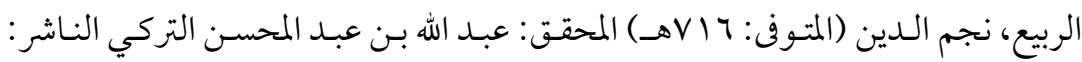

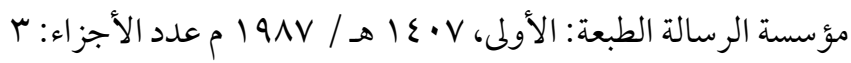

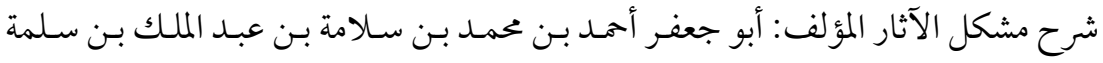

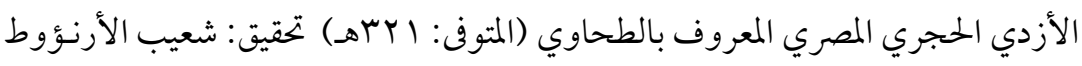

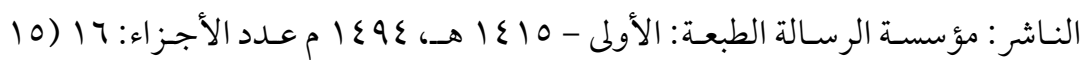
وجزء للفهارس)

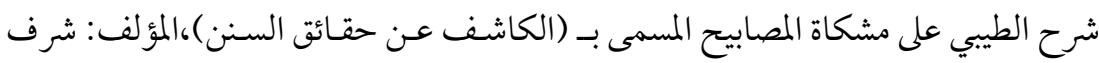

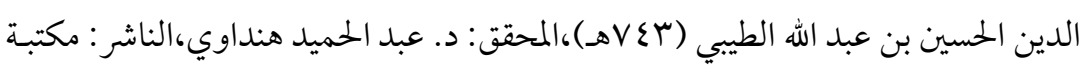

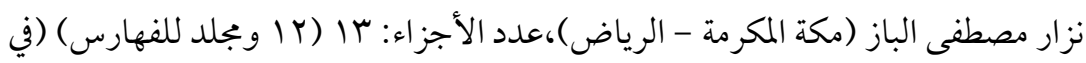

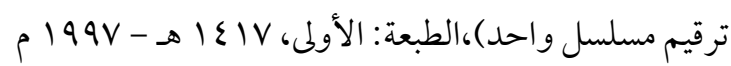

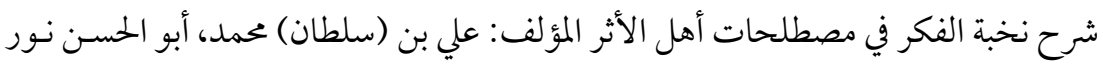

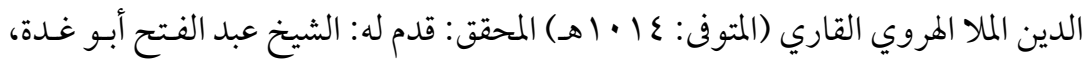

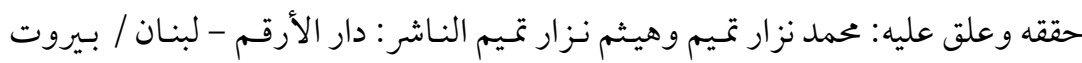

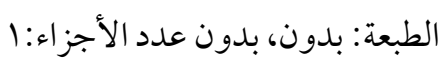

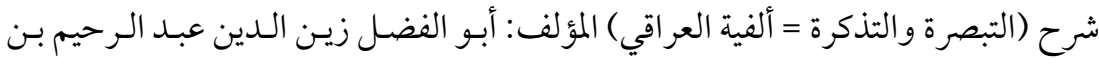

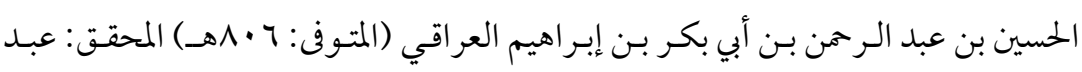

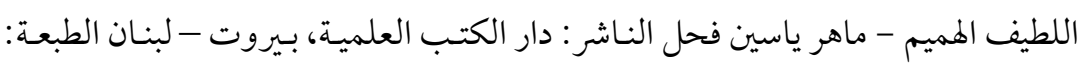

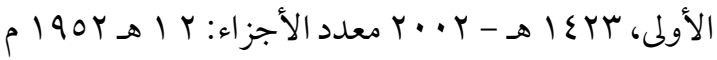

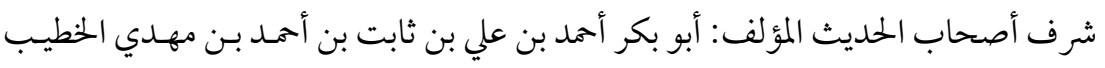

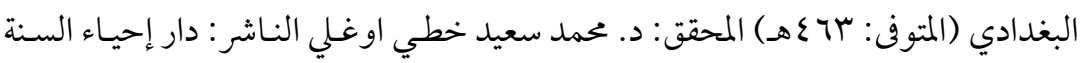

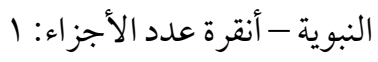


طبقات الشافعية الكبرى المؤلف: تاج الدين عبد الوهـاب بـن تقي الدين السبكي (المتوفى:

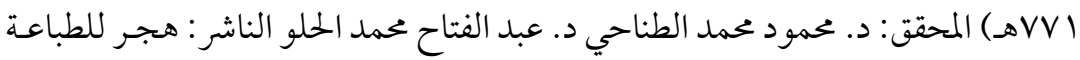

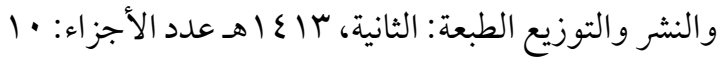

طريق الهجرتين وباب السعادتين المؤلف: محمد بن أبي بكر بن أيوب بـن سعد شـمس الدين الدين

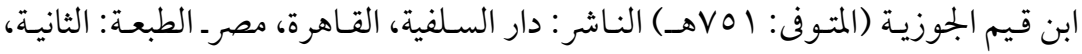

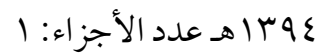

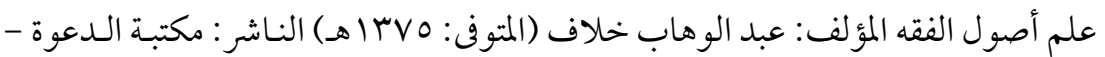

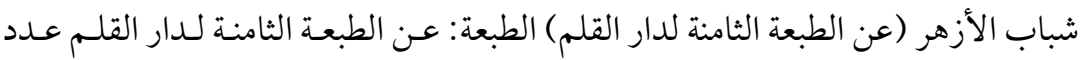

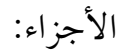

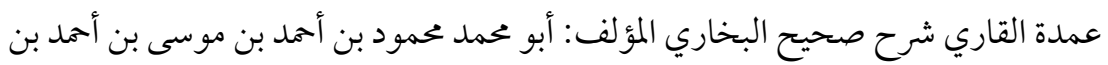

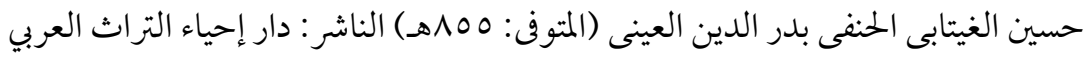

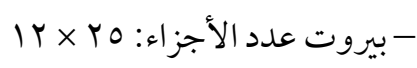

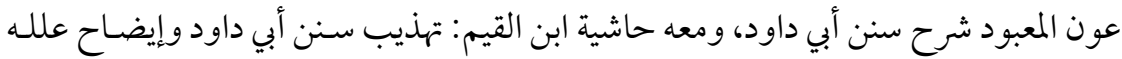

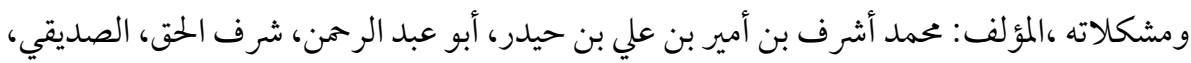

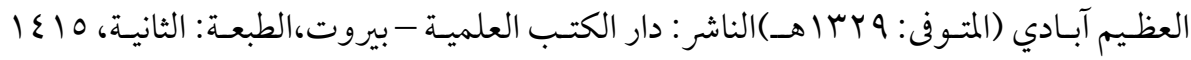

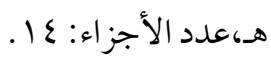
غاية الأماني في الرد على النبهاني المؤلف: أبو المعالي محمود شكري بن عبد الله بن محمد بـن أبي

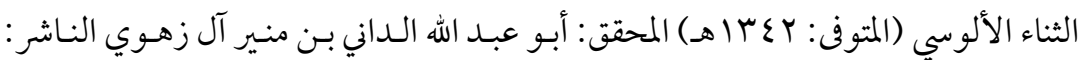

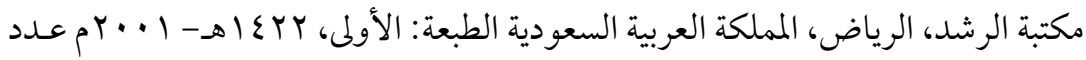

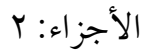

$$
\text { فتاوى دار الإفتاء المصرية المؤلف: دار الإفتاء المصرية }
$$

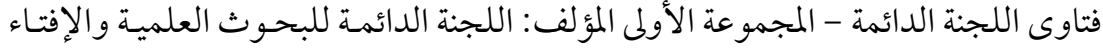
جمع وترتيب: أحمد بن عبد الرزاق الدويش عـد الأجزاء: جب جزءا النـاشر: رئاسـة إدارة

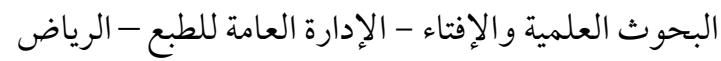

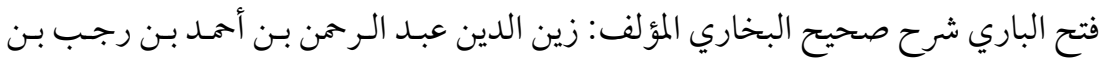

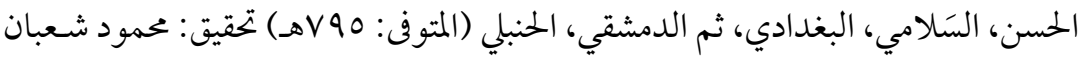

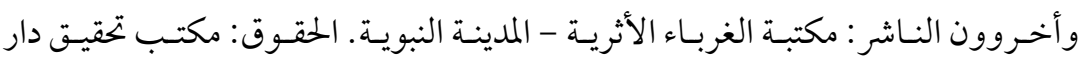

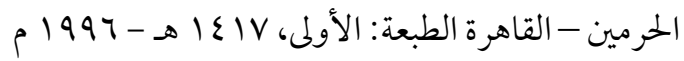


فتح الباري شرح صحيح البخاري المؤلف: أحمد بـن علي بـن حجر أبو الفضل العسقلاني

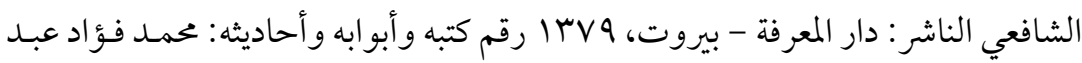

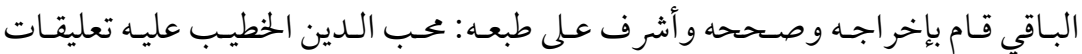

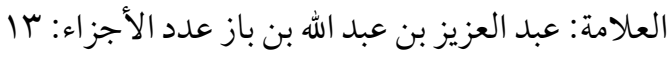

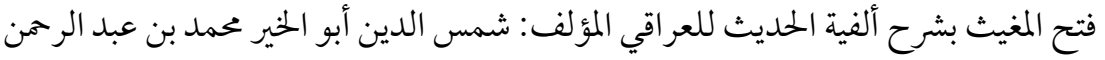

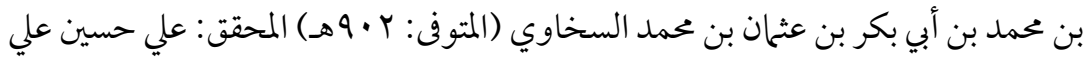

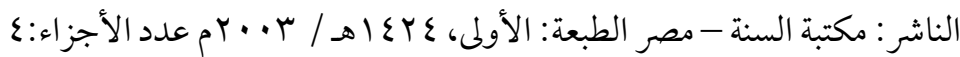

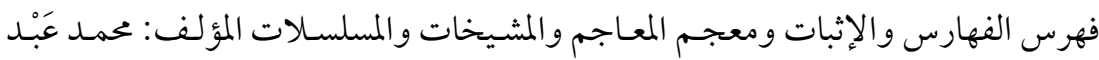

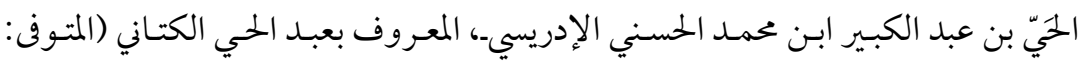

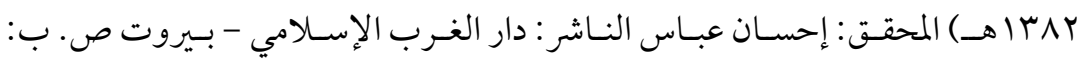

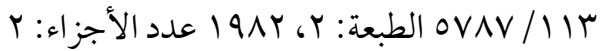

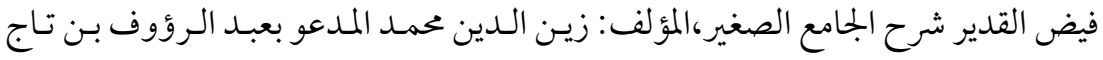
العارفين بن علي بن زين العابدين الحدادي ثم المناوي القـاهري (المتوفى: بــاهــ، الناشر:

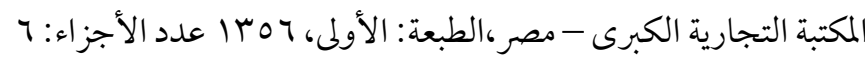

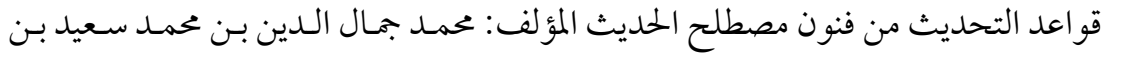

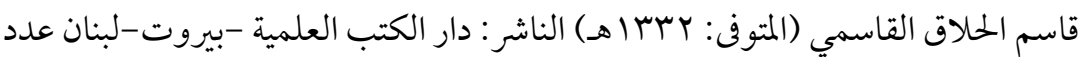

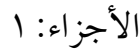
قوت المغتذي على جامع الترمذي المؤلف: عبد الرحمن بـن أبي بكر، جـلال الدين السيوطي

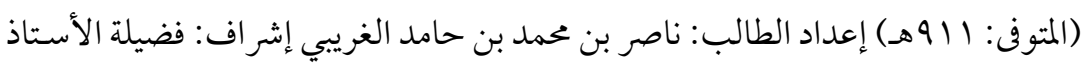

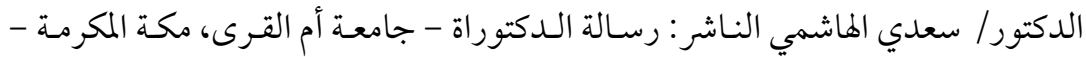

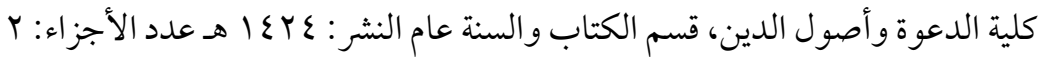
كشف الخفاء ومزيل الإلباس المؤلف: إسماعيل بن محمد بن عبد الهادي الجر احي العجلموني

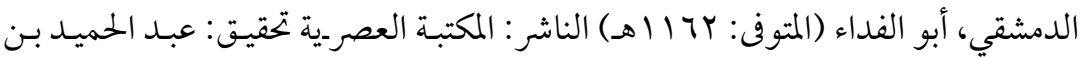

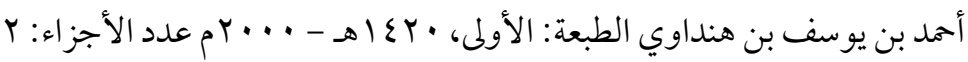

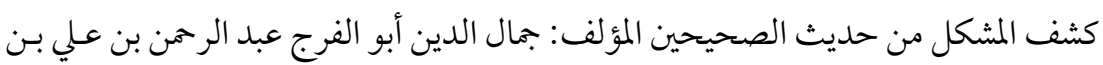

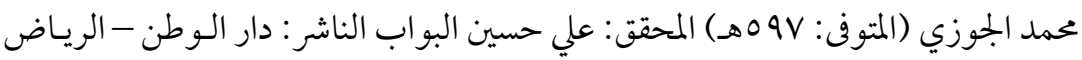

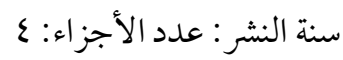


لسان العرب،المؤلف: محمد بن مكرم بن على، أبو الفضل، جمال الدين ابن منظور الأنصاري

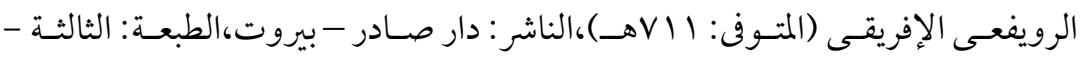

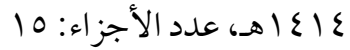

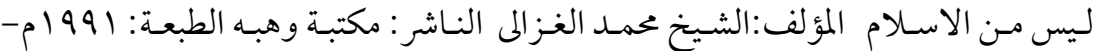

(1)

بجلة المنار (كاملة Oب بجلدا) المؤلف: بجموعة من المؤلفين، محمد رشيد بن علي رضا (المتوفى:

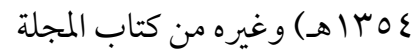

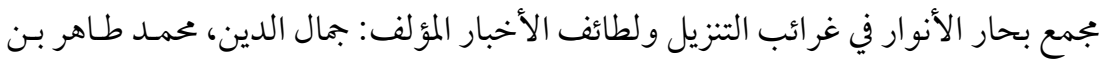

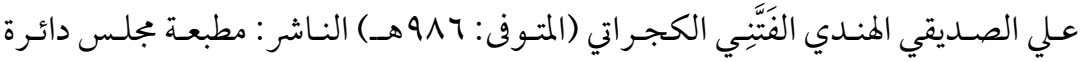

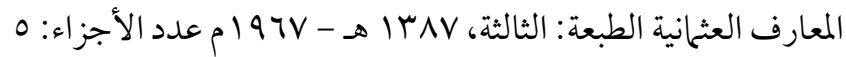

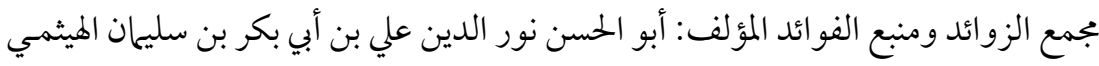
(المتوفى: V•1هـ) المحقق: حسام الدين القدسي الناشر: مكتبة القدسي، القاهرة عام النشري:

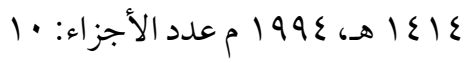
بجموع الفتاوى المؤلف: تقي الدين أبو العباس أحمد بن عبد الحليم بن تيمية الحراني (المتوفى:

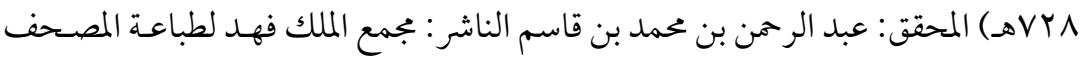
الشريف، المدينة النبوية، المملكة العربية السعودية

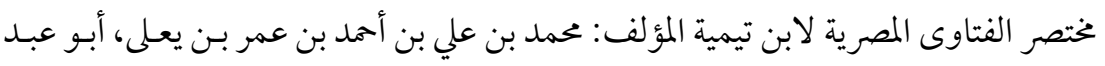

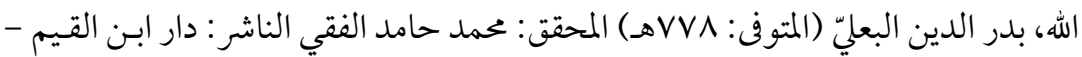

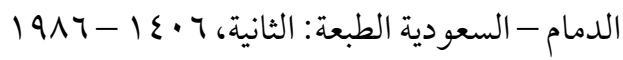

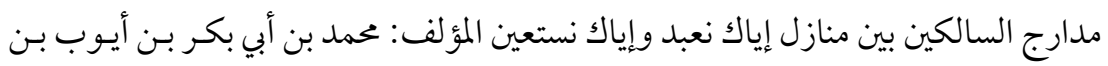

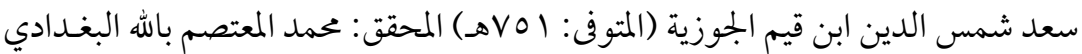

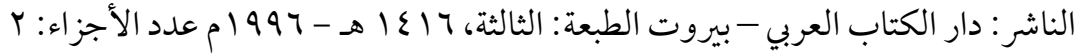

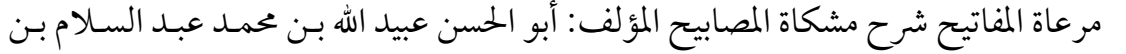

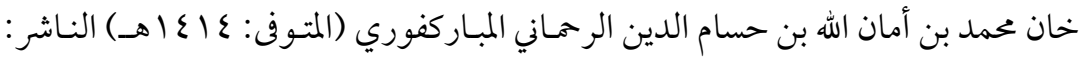
إدارة البحوث العلمية والدعوة والإفتاء - الجامعة السلفية - بنارس الهند الطبعة: الثالثة م $191 \varepsilon ، 1 \varepsilon \cdot \varepsilon$ مرقاة المفاتيح شرح مشكاة المصابيح،المؤلف: علي بن (سلطان) محمد، أبو الحسن نور الدين

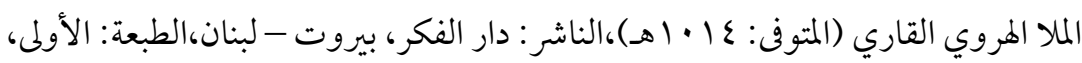

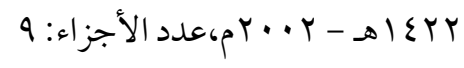




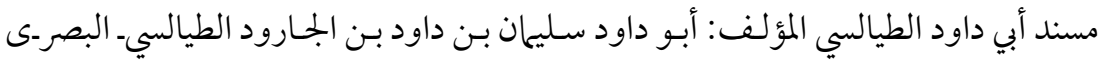

(المتوفى: ع · rهـ) المحقق: الدكتور محمد بن عبد المحسن التركي الناشر: دار هجر - مصر-

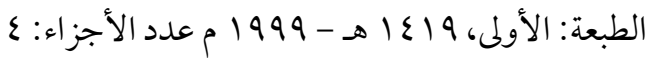

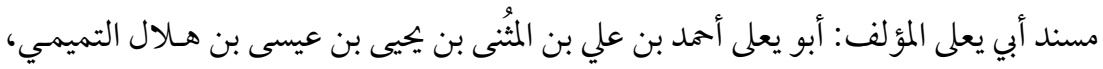

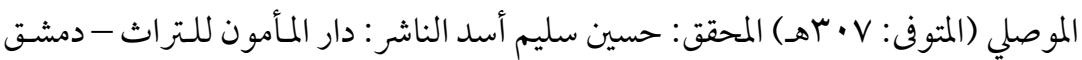

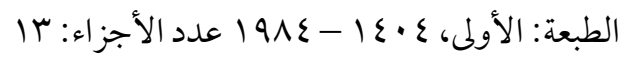

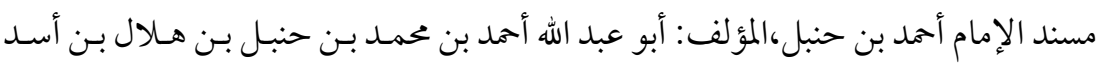

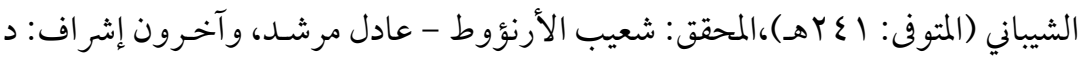

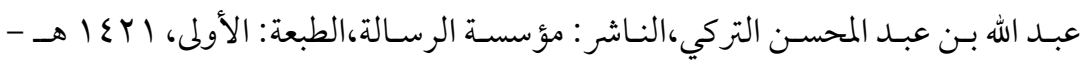

مسند البزار المنشور باسم البحر الزخار المؤلف: أبو بكر أحمد بـن عمـرو بـن عبد الخالق بـن

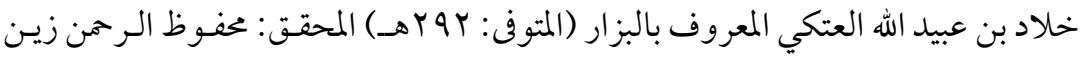

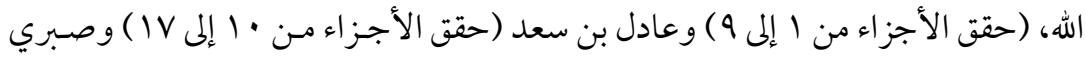

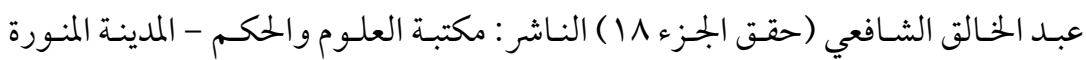

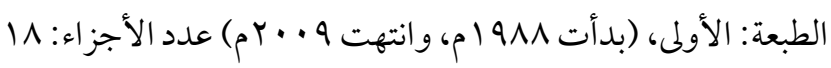

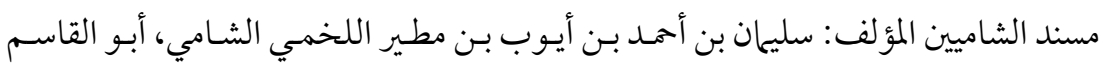

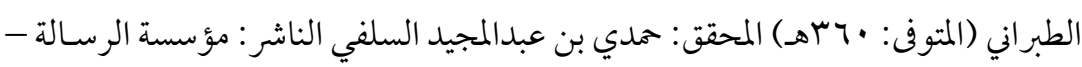

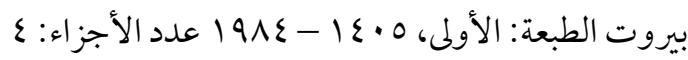

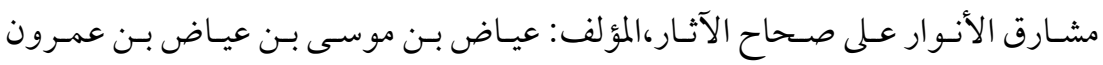

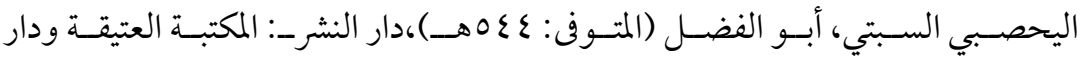

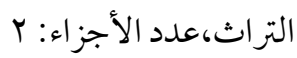

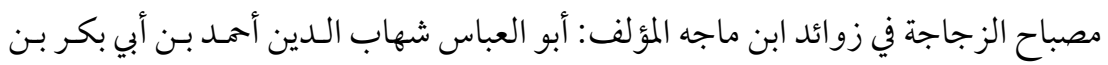

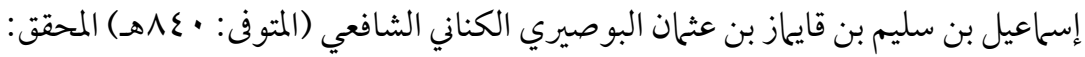

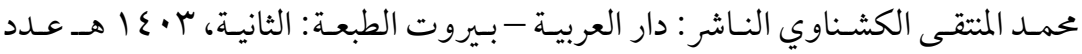

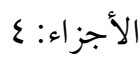

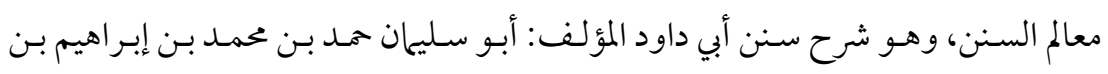

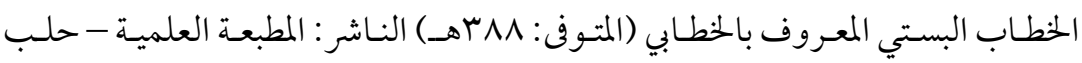

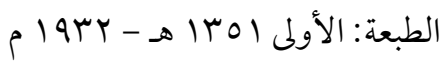




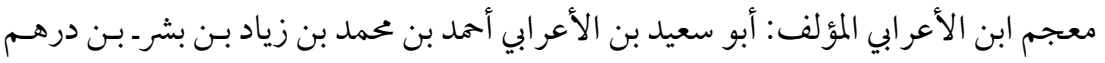

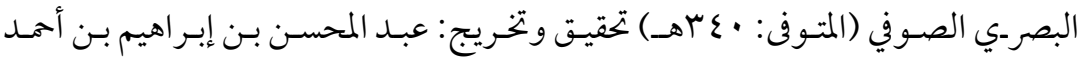

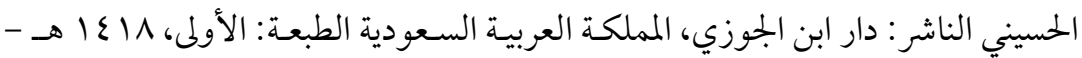

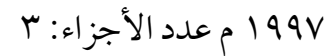

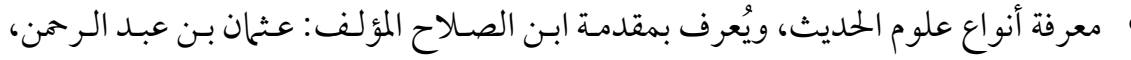

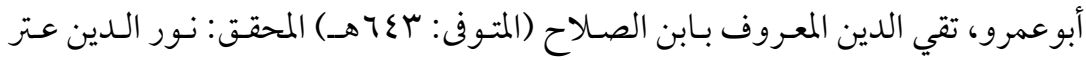

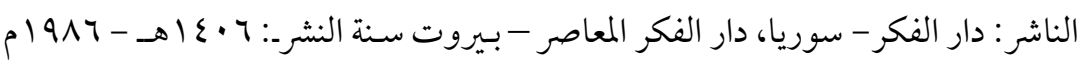

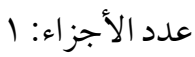

معرفة الصحابة المؤلف: أبو نعيم أحمد بن عبد الله بن أحمد بن إسحاق بـن موسى بـن مهران

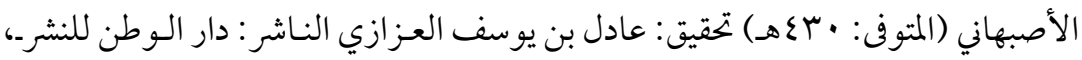

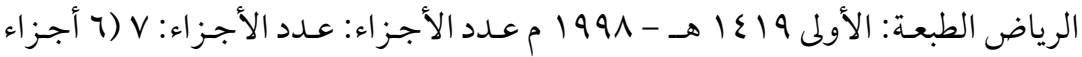
وبجلد فهارس).

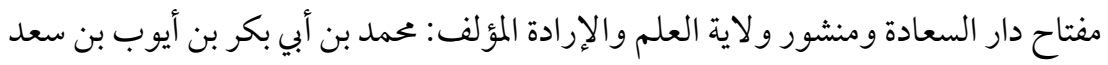

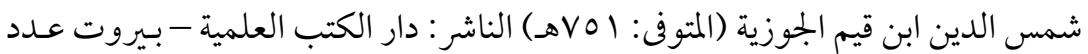

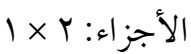
مناقب الإمام الشافعي المؤلف: محمد بن الحسين بن إبراهيم بـن عاصـم، أبـو الحسـن الآبري : الحسي

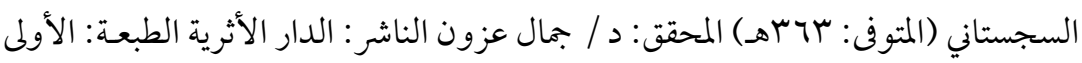

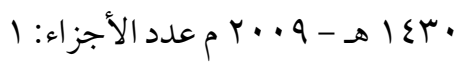

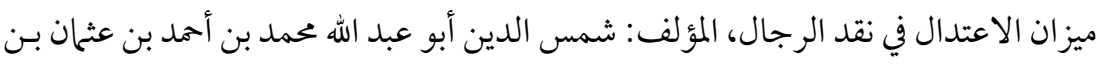

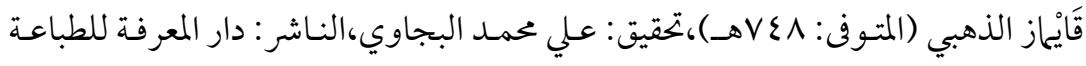

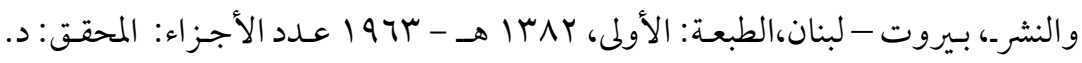

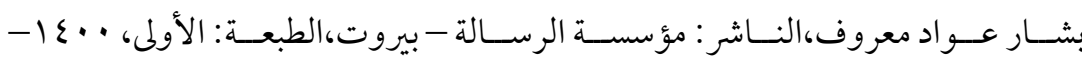

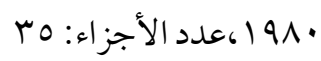

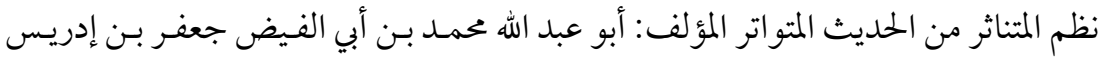

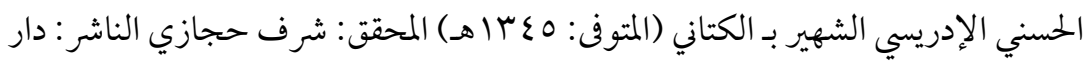

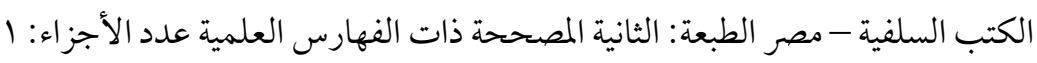

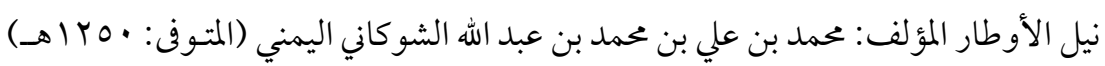

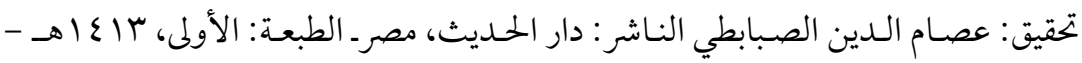

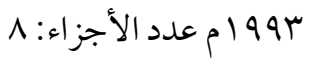




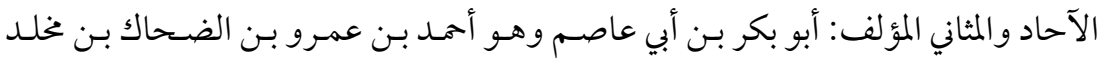

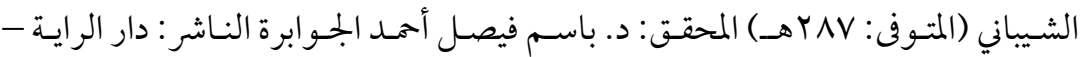

$$
\text { الرياض الطبعة: الأولى، 1| | - 1991 العدد الأجزاء: } 7
$$

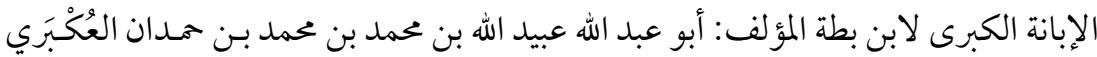

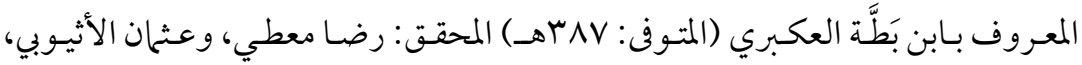

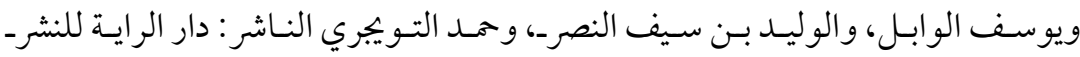

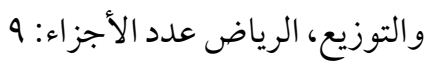

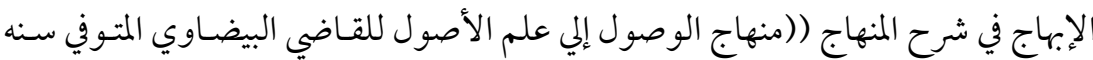

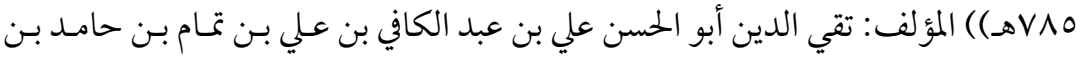

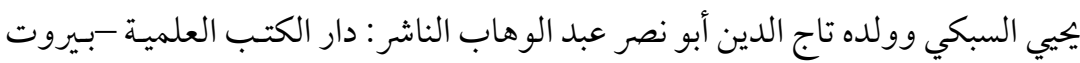

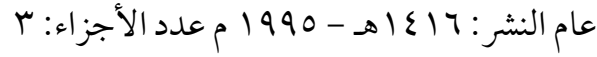

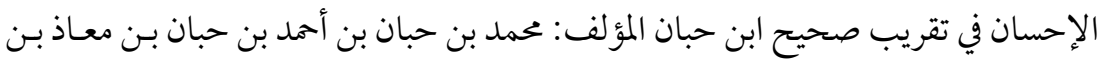

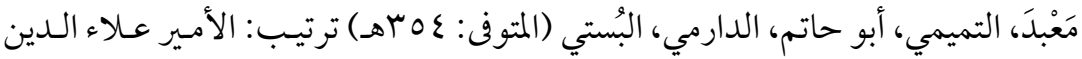

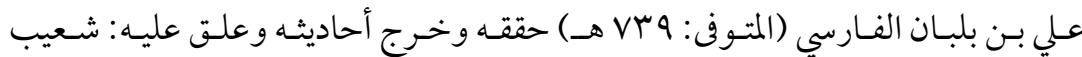

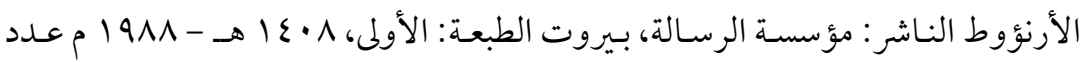

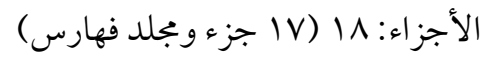
الاعتصام المؤلف: إبر اهيم بن موسى بن محمد اللخمي الغرناطي الشهير بالشاطبي (المتوفى:

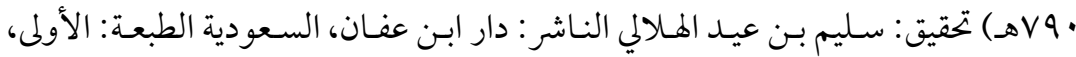

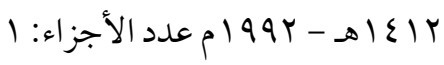

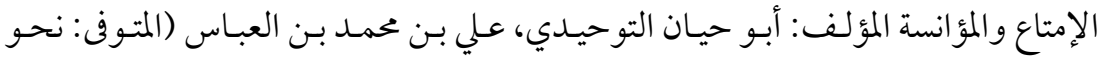

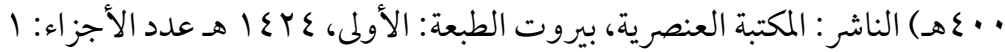
الانتقاء في فضائل الثلاثة الأئمة الفقهاء مالك والشافعي وأبي حنيفة رضي الله عنهم المؤلف:

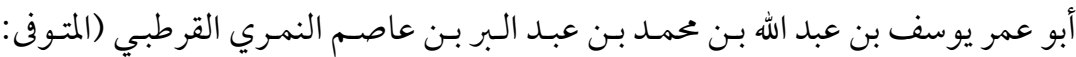

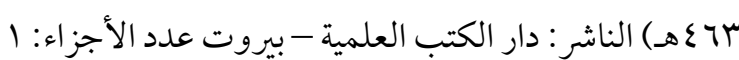

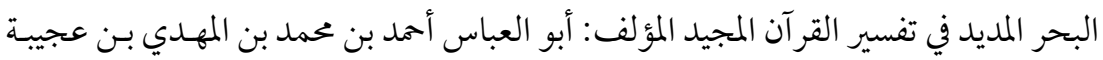

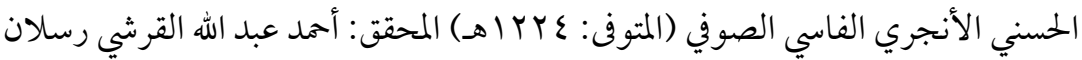

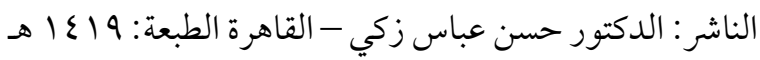




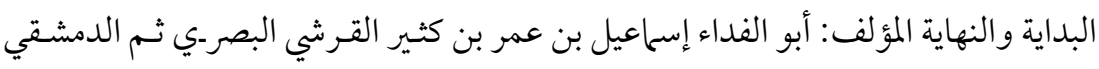

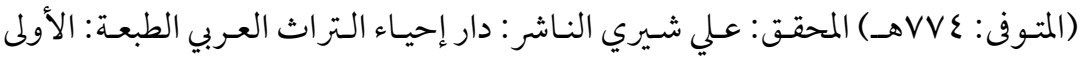

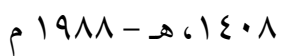

• البدع والنهي عنهاالمؤلف: أبو عبد الله محمد بن وضاح بـن بزيع المرواني القرطبي (المتوفى:

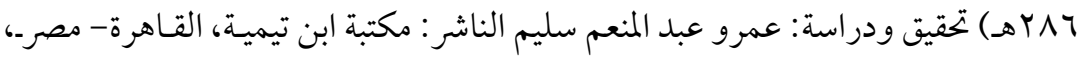

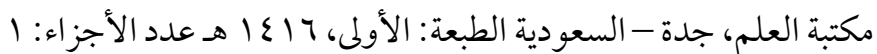

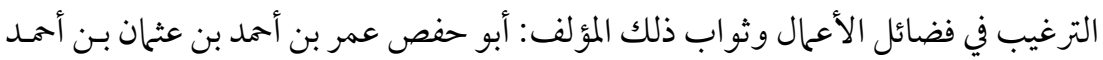

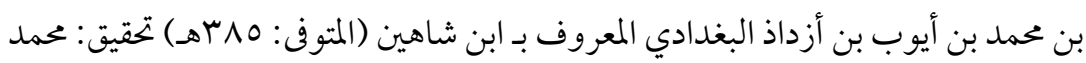

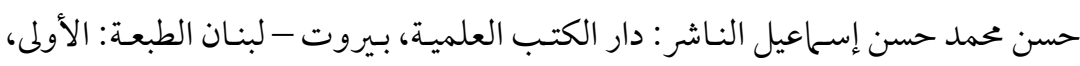

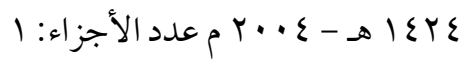

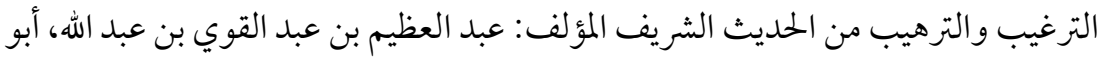

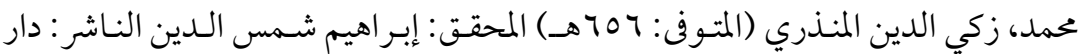

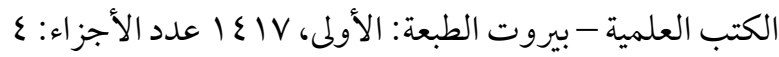

ه التعريفات المؤلف: علي بن محمد بن علي الزين الشريف الجرجاني (المتوفى: 7 1 1هــ

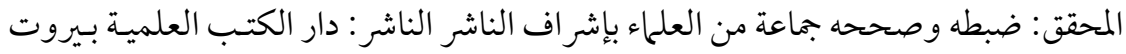

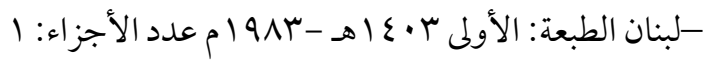

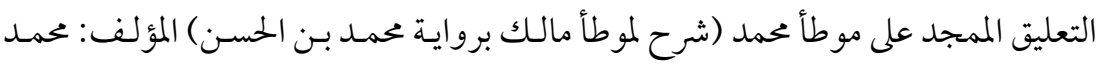

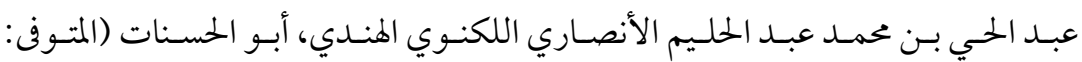

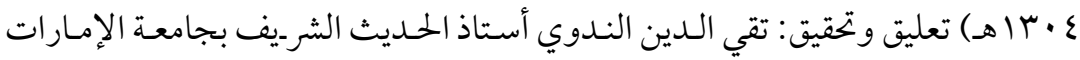

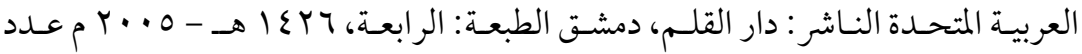

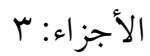

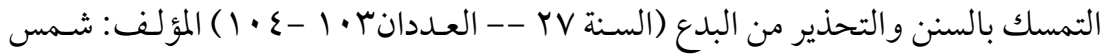

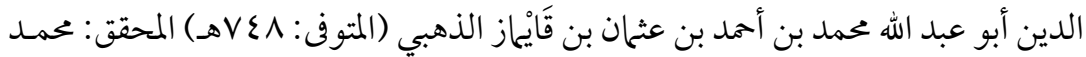

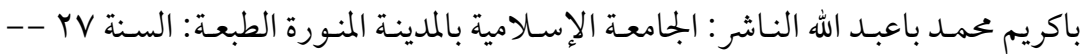

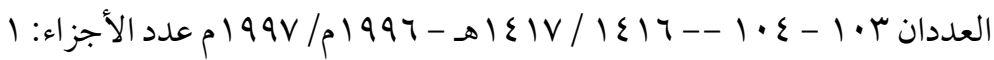

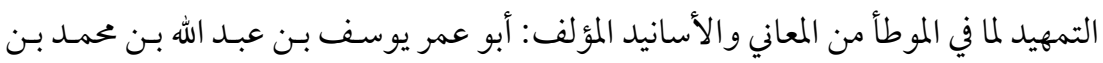

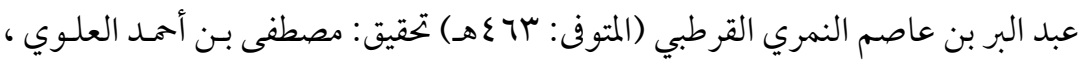

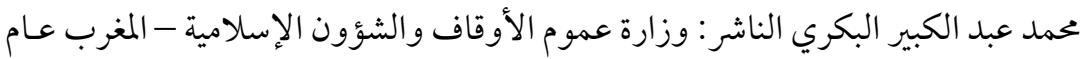

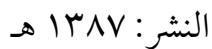




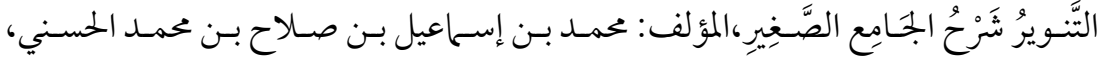

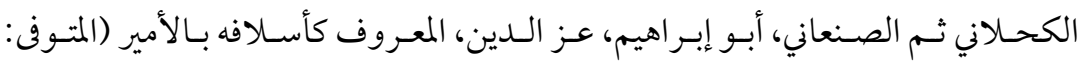

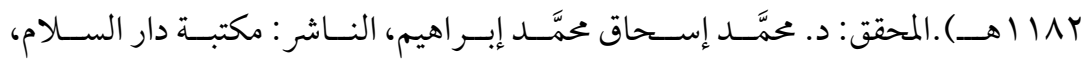

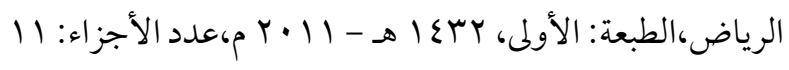

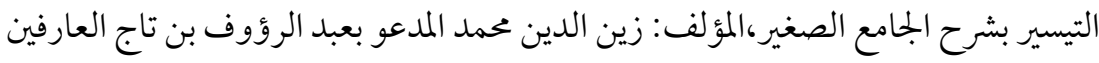

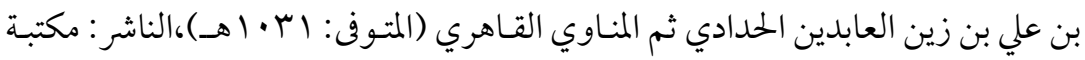

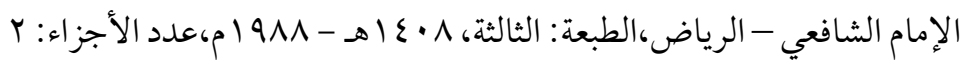

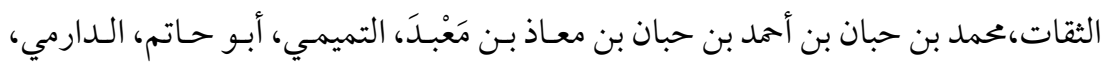

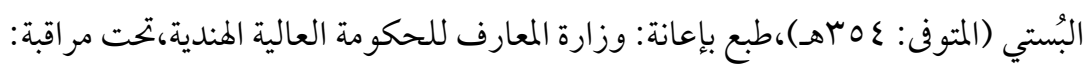

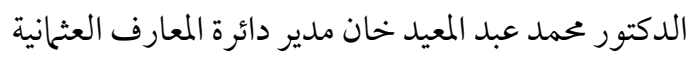

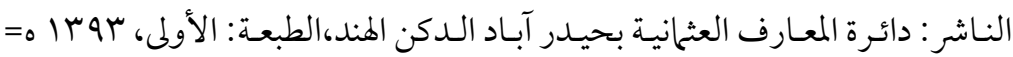

$$
9 \text { ا9 اعدد الأجزاء: } 9
$$

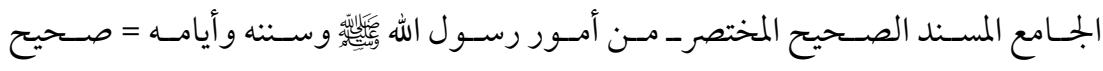

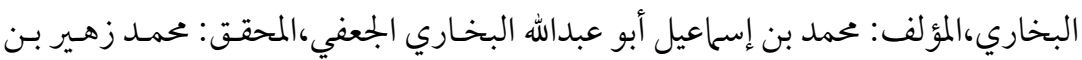

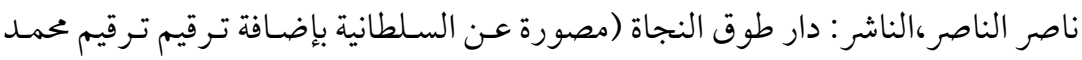

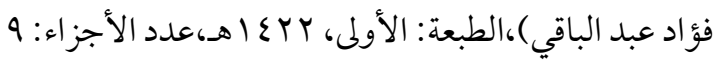

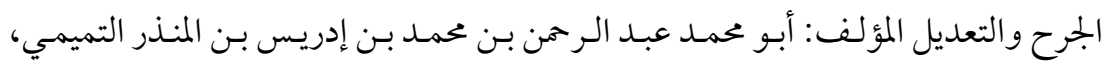

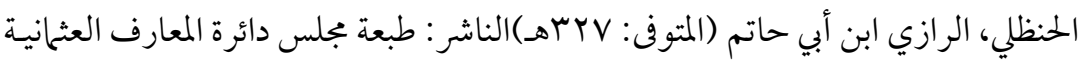

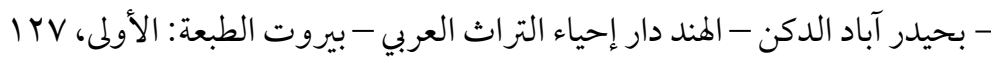

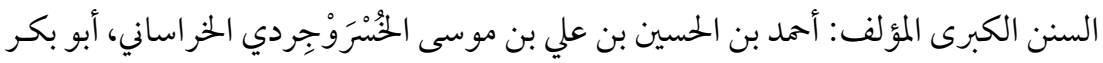

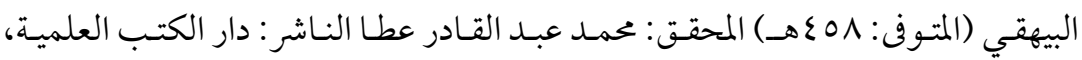

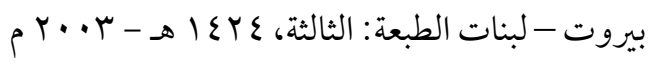

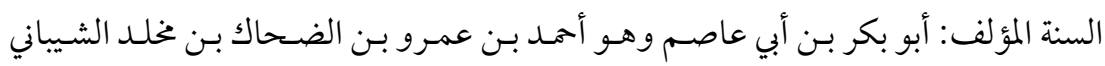

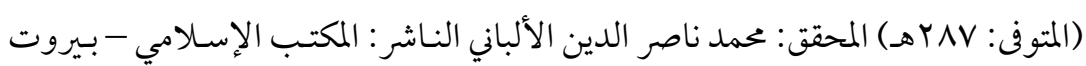

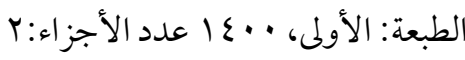

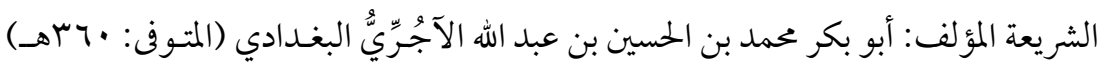

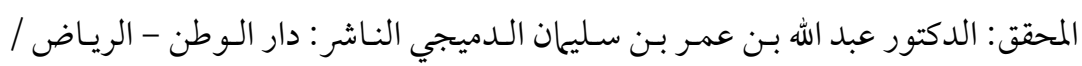

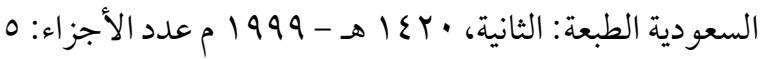




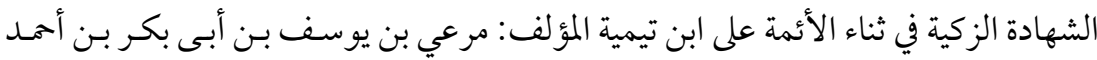

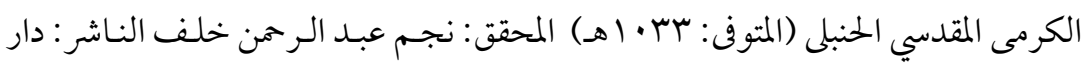

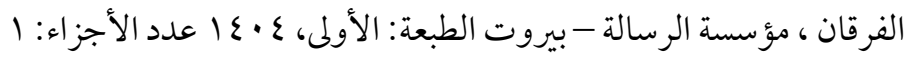

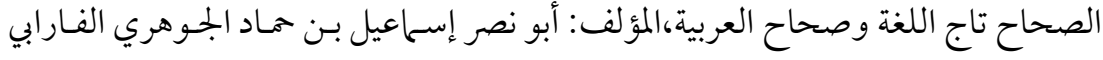

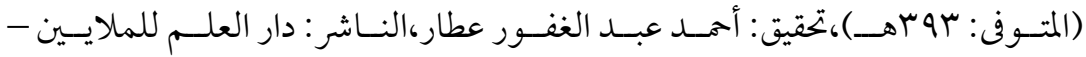

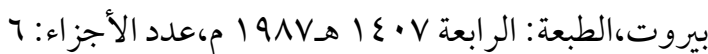
الضعفاء الكبير المؤلف: أبو جعفر محمد بن عمرو بن موسى بن حماد المعاد العقيلي المكي (المتوفى:

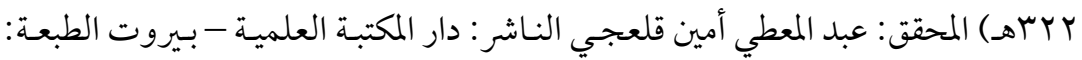

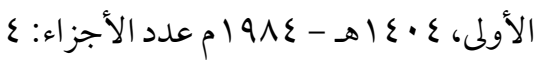

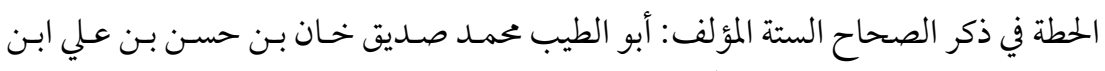

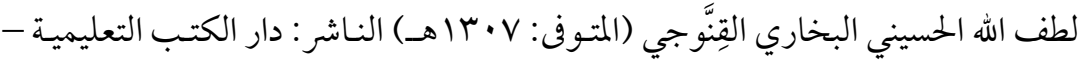

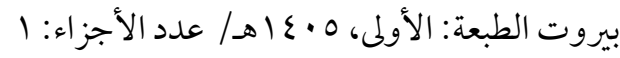

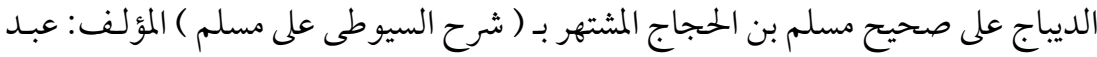

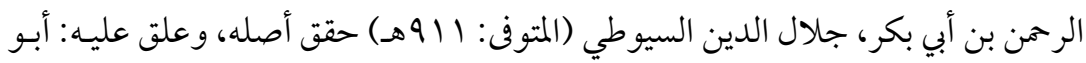

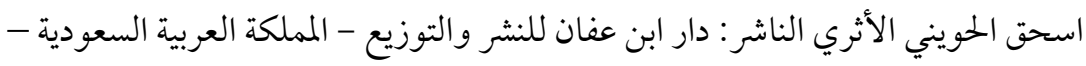

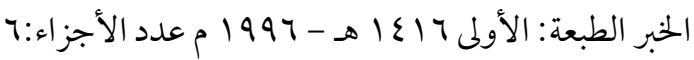

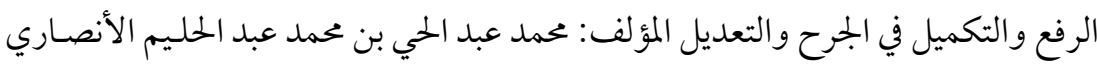

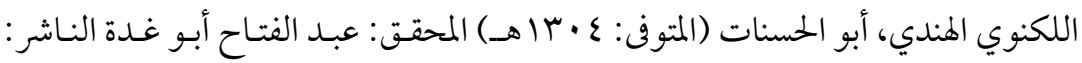

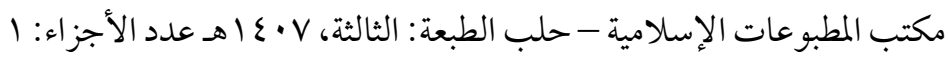

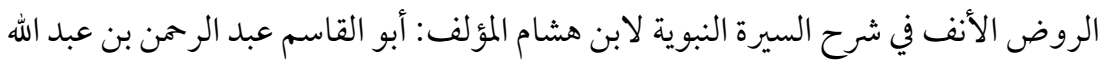

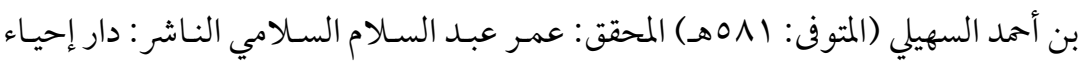

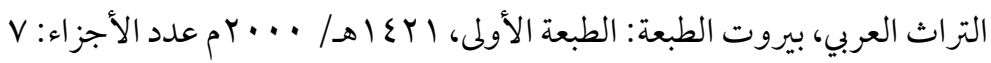

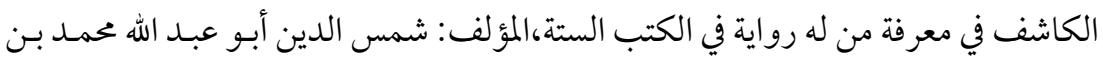

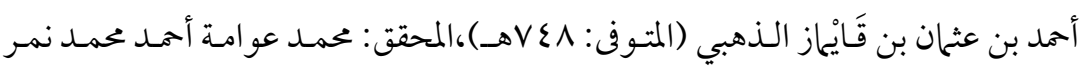

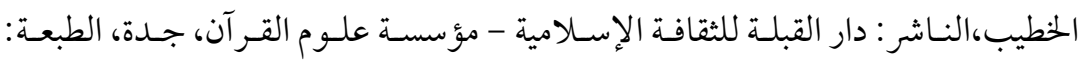

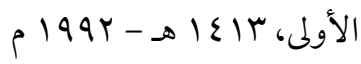

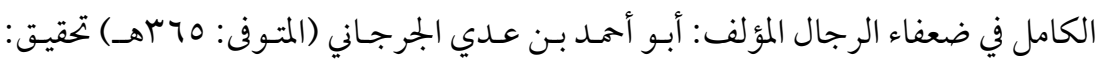

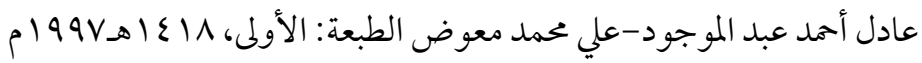




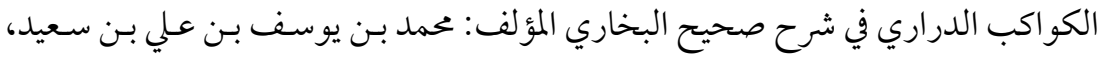

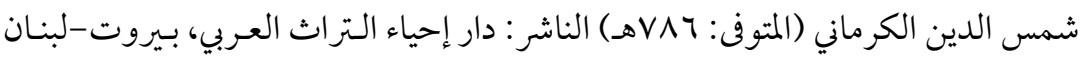

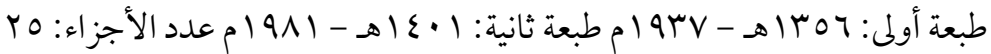

$$
\text { المجتبى من السنن = السنن الصغرى للنسائي }
$$

المؤلف: أبو عبد الرحمن أحمد بن شعيب بن علي الخراساني، النسائي (المتوفى: ب. بـهـ) تحقيق:

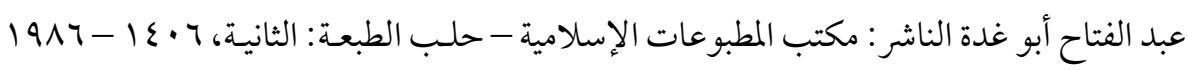

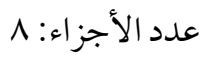

المستدرك على الصحيحين المؤلف: أبو عبد الله الحاكم محمد بن عبد الله بـن محمد بـن حمدويـه

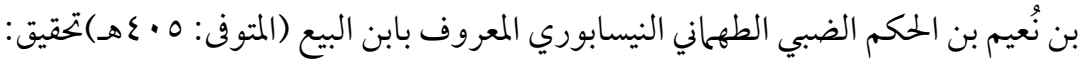

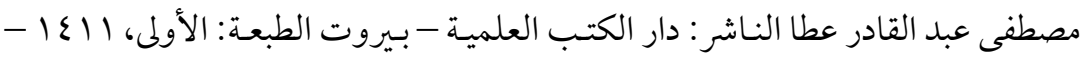

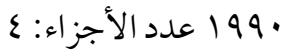

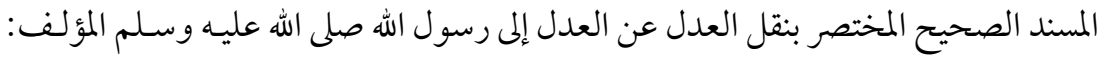

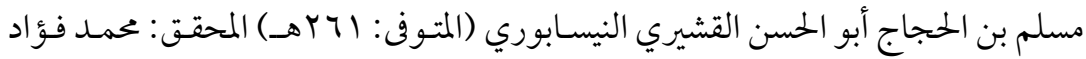

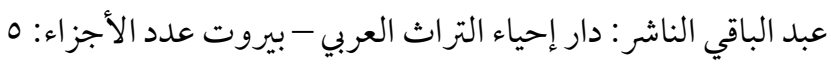

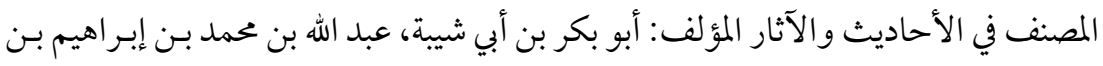

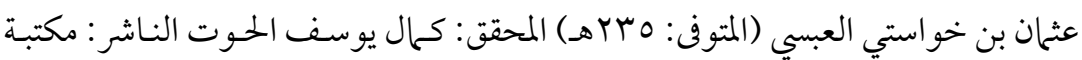

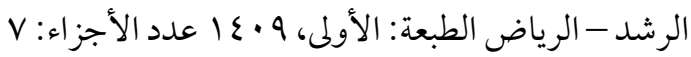

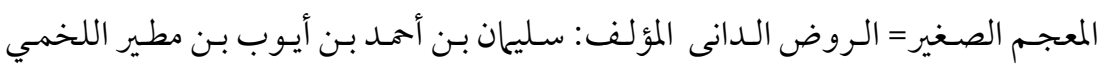

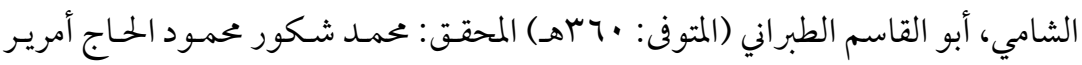

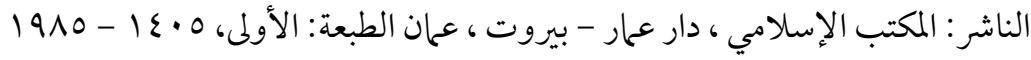

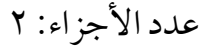

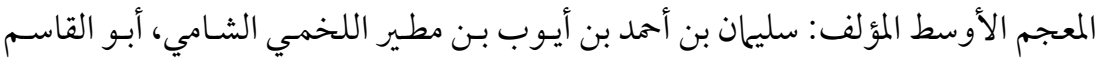

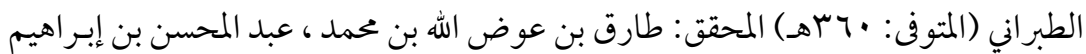

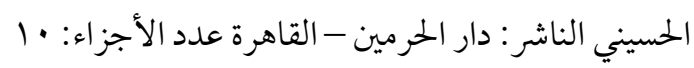

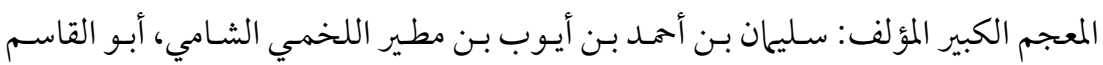

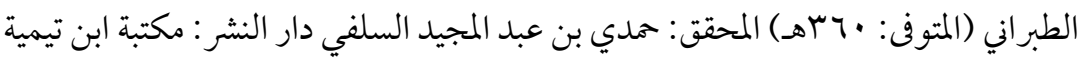

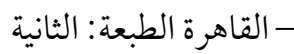


ا المعجم المختص بالمحدثين المؤلف: شمس الدين أبو عبد الله محمد بن أحمد بن عثمان بن قَائماز

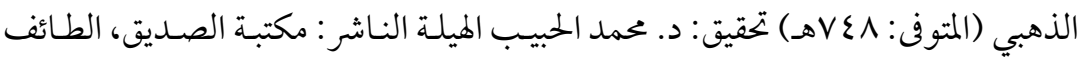

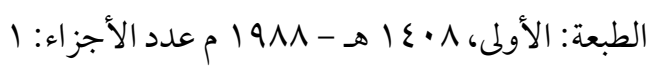

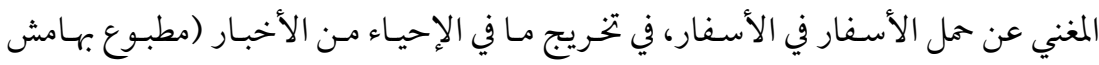

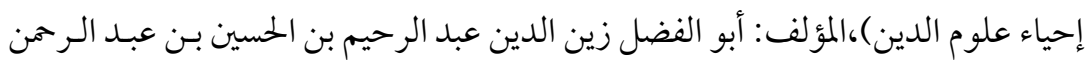

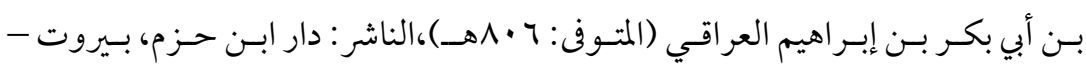

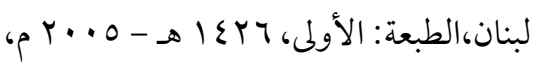

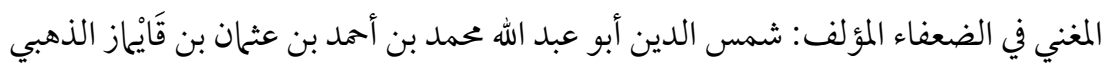

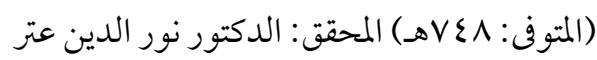

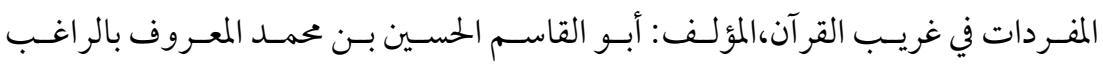

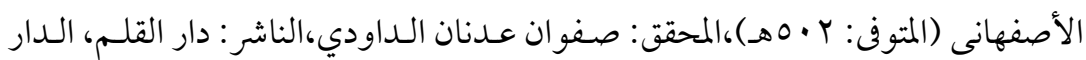

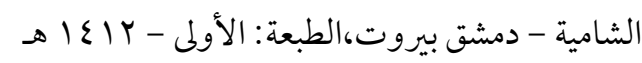

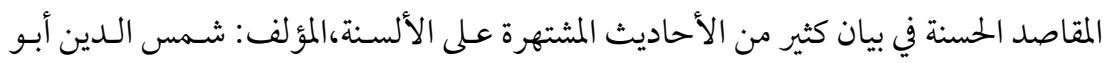

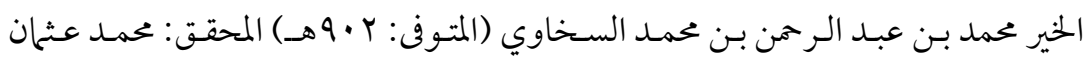

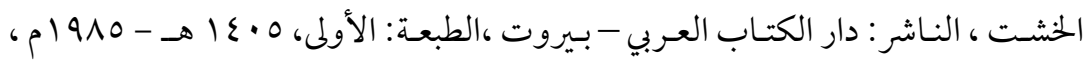

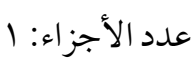
المنتخب من مسند عبد بن حميد المؤلف: أبو محمد عبد الحميد بن حميد بن نصر الكَّي- ويقال

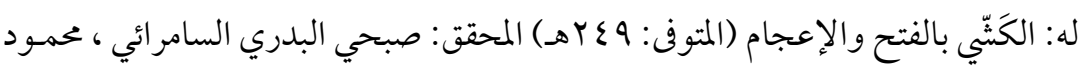

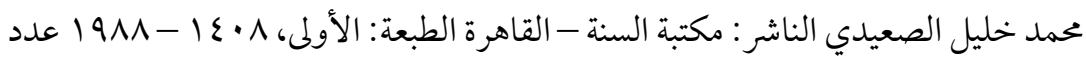
الأجزاء: 1

ه المنهاج شرح صحيح مسلم بن الحجاج المؤلف: أبو زكريا محيي الدين يحيى بن شرف النووي

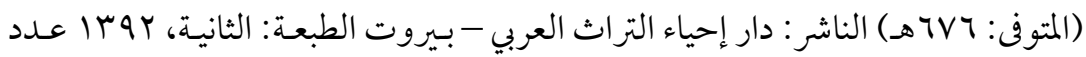

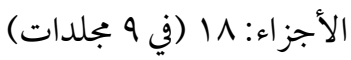
ه المو افقات المؤلف: إبراهيم بن موسى بن محمد اللخمي الغرناطي الشهير بالشاطبي (المتوفى:

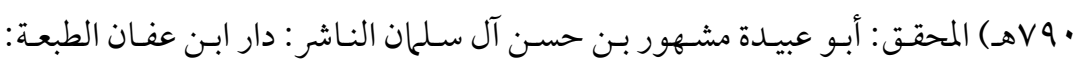

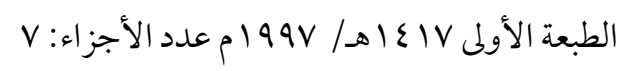

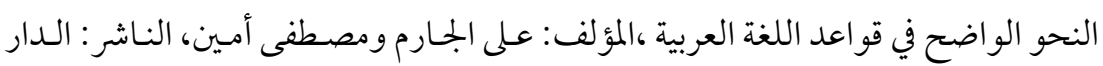

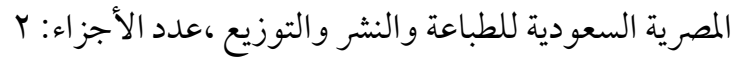


=

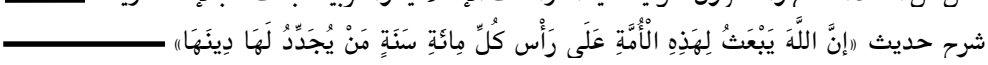

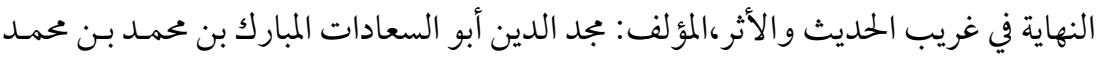

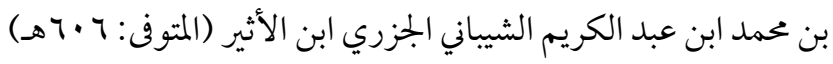

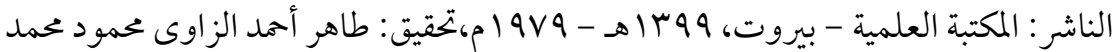

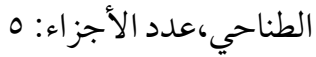




\section{فهريت الموضوعات}

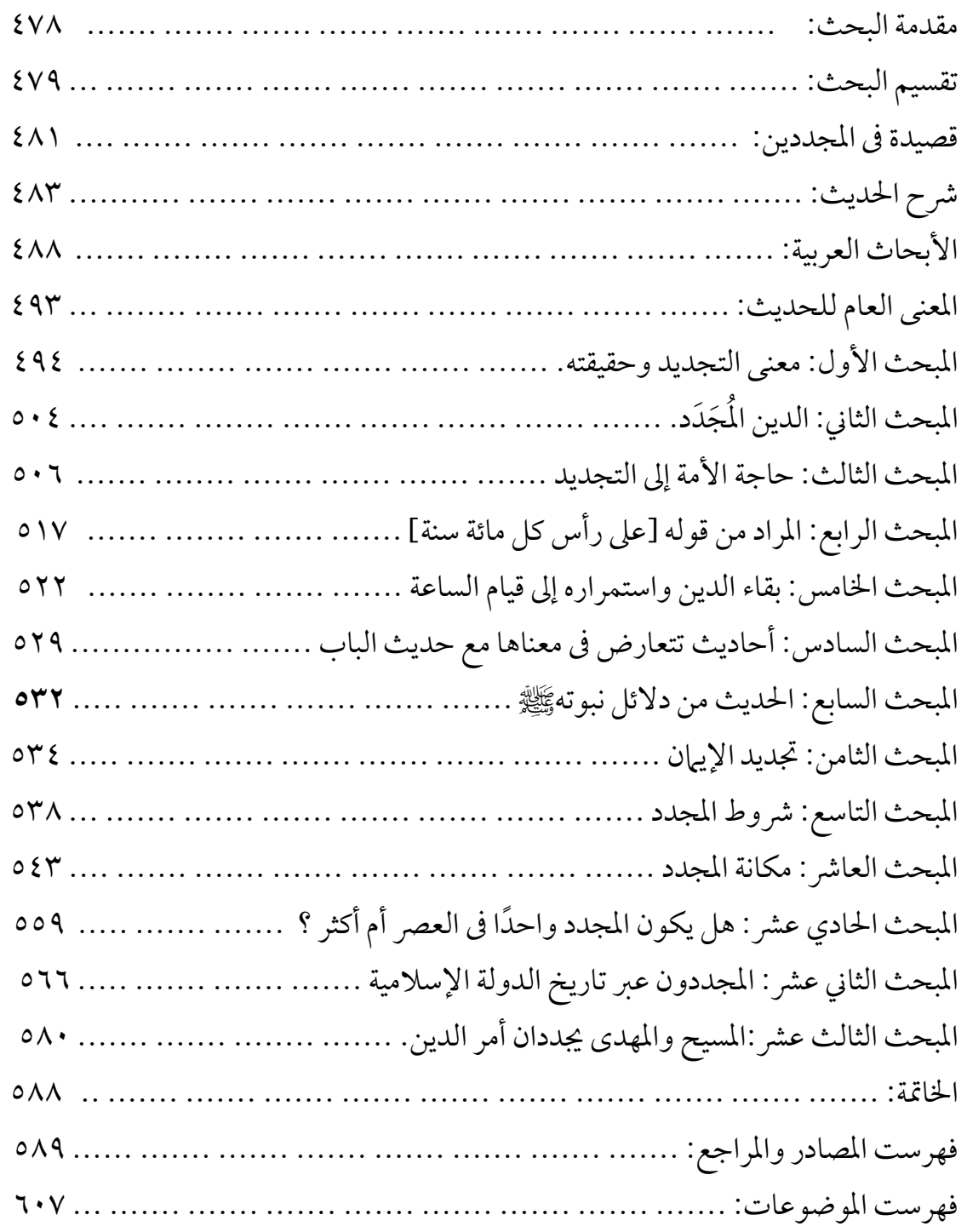

